


\section{.}


date stamned helov 



\section{COMMERCIAL ARBITRATION AND THE LAW}





\title{
COMMERCIAL ARBITRATION AND THE LAW
}

\author{
BY \\ JULIUS HENRY COHEN \\ AUTHOR OF "LAW AND ORDER IN INDUSTR $x$ " \\ "IHE IAW: BUSINESS OR PROYESSION?" \\ "A TEAGUE TO ENMORCE INDUSTRIAL PEACE"
}

D. APPLETON AND COMPANY NEW YORK

I 9 I 8 
Copyrigat, 1918, By

D. APPLETON AND COMPANY

Printel in the Chited States of America 


\section{DEDICATED}

TO

\section{CHARLES L. BERNHEIMER}

WHO, AS CHAIRMAN OF THE COMMITTEE ON COMMERCIAL ARBITRATION OF THE CHAMBER OF COMMERCE OF THE STATE OF NEW YORK,

HAS DONE MORE THAN ANY OTHER ONE MAN TO ENCOURAGE AND DEVELOP THE PRACTICAL USE OF COMMERCIAL ARBITRATION IN THE UNITED STATES 


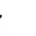




\section{INTRODUC'TION}

\section{I}

The Chamber of Commerce of the State of New York is, I believe, the oldest commercial or trade body in the United States. Its charter runs back to the days of George the Third (April 5th, 1768). The act confirming it was one of the first pieces of legislation passed by the State of New York. Yet almost as old as the Chamber itself is its interest in the arbitration of commercial disputes. In the records of the Chamber are to be found interesting cases disposed of by arbitration during the Revolutionary Period. Just prior to Cornwallis' surrender and at a time when the City of New York was still under martial law, Andrew Elliot, "Superintendent-General," writes (October 2nd, 1781): "As I was and still am of opinion that Mercantile disputes cannot be adjusted in a more proper or more equitable way than by a reference to respectable Merchants, it gave me great satisfaction when the method was so generally agreed to, and I flattered myself that notwithstanding the trouble it gave individuals, that it would at least continue as long as I had any concern in the Superintendency. I shall be much concerned if these, my expectations, should be disappointed." $\mathrm{He}$ then makes the following painful reference to the then existing condition: "The present Juncture of Affairs does not seem favorable for any new plans to be adopted. It has long been proposed (I hope Events are not distant that may admit of a Trial) to revive such part of the civil Au-

${ }^{2}$ April 13th, 1784, Chap. XXX, Laws of 1784. 
thority by which justice may be administered to the Cominunity. Individuals will then be freed from the Burthen of adjusting Mercantile disputes, and I shall be relieved from a most fatiguing anxious situation, but I beg you will assure the Chamber of Commerce that in all situations I shall ever retain the highest seuse of Assistance and Support they have afforded me.'” From 1874 down to 1895 the Chamber housed the Court of Commeree or Court of Arbitration established by the Legislature of the State in April, 1574. Over this Court the late Judge Enoch L. Fancher presided. Herein partnership cases, claims for salaries, cases arising on bills of lading, on shipments of goods from abroad, on marine insurance, etc., etc., were submitted to the arbitrator and satisfactorily disposed of. In 1911 a special Committee on Commercial Arbitration ${ }^{3}$ recommended the plan for commercial arbitration which has since been in rogue. This plan is based upon the provisions of the Code of Civil Procedure of the State of New York permitting voluntary submissions to arbitration and provided for the entry of a judgment upon the award and the enforcement of the judgment as a judgment of a court of record. This system, to my personal knowledge, has worked to the eminent satisfaction of all eoncerned. $\mathrm{MY}$ experience is in accord with that of Sir Albert $\mathrm{K}$. Rollit, Ex-President of the London Chamber of Commeree and Clairman of its Arbitration Committee, who said on Feb. 19, 1909:

"Arbitration is indeed the natural right of disputants to choose their own tribunal, and is the praetical art of vindicating and reconeiling disputants, and doing so at a minimum of expenditure, time and trouble.

"Except for arbitration there would be many eases in which justice would be denied.

2 Recoris of Chamber of Commerce, Octoher, 1781.

"Jamer 'Taloott, Jenry Hentz, Frank $\Lambda$. Ferria, Alexander F. Orr, Charles I. Bernheimer, Chaimun. 
"Even rough and ready trade arbitrations are neccssary in modern commercial life.

"There is no rivalry in arbitration with the law or the administration of the law."

But business men engaged upon this side of the ocean in administering arbitration committees have found it difficult to understand why, as matter of law, existing disputes could be submitted to arbitration, yet they could not in advance agree, as part of the consideration for their entering into a contract, that, in the event of controversy over the contract, the dispute should be referred to their own Exchange or Board of Trade or Chamber of Commerce or to arbitrators selected by them. That judges as well as laymen had the same difficulty appeared when, in 1915, Judge Charles M. Hough, one of our ablest Federal Judges, in U. S. Asphalt Refining Co. v. Trinidad Lake Petroleum Co., ${ }^{4}$ stated that he could find no basis in reason for the existing law; yet, upon old precedent, he was constrained to hold that a clause in a contract by which the parties solemnly agreed to submit their differences, if any arose, to arbitration, was revocable at the pleasure of either. At about the time of the rendition of this decision, our Committee on Commercial Arbitration was considering the wisdom of applying to the Legislature for relief from what we regarded and still regard as an anomalous condition in the law. In the summer of 1915 we asked the Constitutional Convention then sitting in Albany, to insert in the Judiciary Article the following: "The legislature is authorized to make provision for submission of controversies, existing or non-existing, to arbitration, and to validate agreements made by the parties to that end." We were told by the Chaimnan of the Judiciary Committee of the Constitutional Convention that no such authority was necessary. On the other hand one of the leading legal authorities in this country on August 19th, 1915, wrote us:

- 222 Fed. Rep. 1006. 
"But I cannot say that I am yet certain that the long established reluctance of the courts to surrender jurisdiction, should be set aside."

The decision of Judge Hough came to the attention of the London Court of Arbitration at about the same time. Shortly after its rendition, the London Court called our attention to the fact that, if the judgment of Judge Hough were not reversed on appeal or the law ehanged, "a Citizen of the United States of America would be in the position to enforce an Award in his favour wherever delivered against a British subject, whether resident in England or any British Colony or Dependency . . . whereas, should the Award go against him, he could ignore it." That such a condition eould exist seemed inexplicable to the London merchants (and to Ameriean merchants as well), who reported that "Recourse to arbitration in this Country (England), is very general, and it is a gratifying tribute to the effieiency with which justice is administered in the London Court of Arbitration, that Foreign Merchants readily assent to the insertion in their contracts of a clause providing for the reference of differences thereto."

Mr. Justice Vernon M. Davis, in administering the oath to our committee on the 1st of June, 1911, had said: ". . . it is the poliey of the law to encourage arbitration." And another well-known jurist in our community, ExJustice Francis M. Scott, had said that there was no difference between "the promise to forbear to prosecute a particular claim upon whieh one has a right to sue" and a promise to forbear to pursue their renedy by action in the courts of the State. "The cause of action to enforce the judgment was the plaintiffs'. They could do with it as they saw fit to the extent of releasing it wholly on the one liand, or of prosecuting every legal method for its collection on the other. Whatever course they saw fit to adopt was no matter of public concern, and affects no ques. 
tion of public policy, and if they saw fit to make an agreement, otherwise valid, that they would forbear to pursue their remedy by action in the courts of this state, there is no public policy which renders that agreement invalid."'5

We found ourselves quite in agreement with our friends in London, who wrote us that "The argument that a party to a contract between nationals of different states may not substitute an independent Arbitral Tribunal for a Court of Law, should surely be regarded in the twentieth century as obsolete."

We were convinced that something should be done to harmonize the law of the United States with the law of England. Our Committee had had long and earnest counsel with its legal adviser upon this subject, and gave consideration to a plan for securing relief from the Legislature of the State of New York. In 1916, however, Mr. Clarence M. Lewis, a member of the New York Bar, in the case of Spiritusfabriek Astra, of Amsterdam, Holland $v$. Sugar Products Company, took issue, on behalf of his client, with this hoary doctrine in the law, and with a view to securing its judicial reconsideration appealed to the New York Chamber of Commerce to intervene as a friend of the Court and to present the business man's point of view. His appeal to the Chamber did not go unanswered. Mr. Julius Henry Cohen was requested to represent the Chamber in the case referred to. I will leave Mr. Cohen to tell the rest of the story. Suffice it to say that the results of his research appealed so strongly to our Committee that we determined not to wait for the submission of a brief to be used only in Mr. Lewis' case, but to print the results for the use of the Bar, the judiciary, and the laity throughout the country and elsewhere. We were convinced that a careful presentation of the history of the doctrine, its original error, its repetition in ignorance, and its final overthrow by the English courts, must - Gitter v. Russian Co., 124 App. Div., 273, at p. 276. Italies ours. 
result ultimately in the rectification of the American error ly our own courts. If, as we believe, the policy of the law is favorable to commercial arbitration, the courts will surely not hesitate to set the law right upon discovery of their error.

Charles L. Berinhemer, Chairman, Committee on Arbitration, Chamber of Commerce of the Stale of New York.

New York.

\section{II}

In one of the wings of the Metropolitan Museum of Art they have re-erected "Perneb's Tomb." Forty-five hundred years ago an Egyptian of importance, by the name of Perneb, a very confidential adviser to the king at Memphis, built this wonderful mansoleum. To bring it to New York required that it be dug from under the great mound of débris heaped upon it. The various blocks had to be taken down, carefully separated, and shipped to this eountry. Then they had to be put together again and the entire tomb re-erected as it now stands in the large gallery at the northern end of the Fifth Avenue hall. In deseribing the details of the work of taking down the structure, Albert M. Lythgoe, who had charge of the work, refers to the rare opportunity which he thus had of seeing in reverse order the various details of the erection of the tomb. Thus, for axample, he found upon many of the backs of the blocks original "mason's marks" written in red ochre, while a great pateh of the paint itself he found in the sand just north of the tomb, where it had been thrown. On the backs of the walls he found places where the mortar still bore "the hardened imprints of the fingers of the workmen as distinetly as on 
the day when the blocks had been placed in position," while under the remains of the plaster and mud flooring of the offering chamber there were still to be found "the scattered shells of a number of nuts which some workman had had for his luncheon on the day he was laying the floor."

About a year ago, when I stood inside the tomb and read this paragraph by Lythgoe, I found myself envying the opportunities that he and his associates had had. The joy of going over this work "in reverse order" through "all the various details of its erection," at the same time feeling human touch with men who, 4500 years before had put the building together, was a rare human experience.

The memory of this visit to Perneb's tomb came back to me when $I$ began the task of digging under the mound of débris covering the ancient doctrine $I$ was charged by the New York Chamber of Commerce to examine and study. As the process of taking down the structure of this ancient tomb, brick by brick, went on, I became more and more interested in discovering upon the backs of the walls "the hardened imprints of the fingers of the workmen" and "the scattered shells" of the nuts which they ate for luncheon. For example, the discovery that the notorious Baron Jeffreys had enunciated a doctrine more equitably sound than that firmly imbedded by my Lord Coke in the brick and mortar of the English Common Law made me nearly drop my pick and shout. In brief, the process of reviewing in "reverse order" the ways of thinking of Coke and Jeffreys and later Eldon and Bramwell and Cranworth and Campbell gave ine a time of enjoyment comparable somewhat with the pleasures of the Museum staff when tearing down and reconstructing Perneb's tomb. I think, too, I found the shells of some of the nuts.

When I first began the work, I had no other purpose 
than to present adequately to the Court all the phases of public policy bearing upon the question. To do this, it seemed to me appropriate to ascertain the true reason for the development of the rule. This, obviously, required the applieation of the historical method. I confess that I was surprised to discover what I believe now to be the fact, that grave judicial error had been committed and repeated for over three centurics solely through failure to secure and present a complete historical analysis of the evolution of the law upon this subject.

I agree with my friend, Everett V. Abbot ${ }^{6}$ that judieial errors should be corrected by the judieiary and that this method "is obviously the wisest, the most effective and the most just." As he says: "The mere fact that there has been error signifies that there has been injustice and the courts are better fitted to cope with injustice than any other department of an organized state." I agree with him that the courts "should always be ready, therefore, to apply to their own errors and injustiees the judicial method of correction" and that a frank acknowledgment of this kind "and an open-minded reception of lawyer-like and respeetfuı arguments tending to point out errors" will, instead of undermining their authority or diminishing the respect in which they are held, on the contrary "the more tolerant and approachable the Court is, the greater will be the popular confidence in its decisions." I think he is perfectly sound in saying that "the strongest bulwark which the courts can erect against the recall and other insidious attacks upon our judicial system will be found in the recognized practice by the courts themselves of the principle that judicial errors are to be judicially corrected."

My experience in this partieular piece of work also confirms my friend in another statement made by him in

- Yale Law Journal, Vol. ?ti, No. :2, p. 104 (Dec., 1916). 
another place." "The existence of an erroneous doctrine in the law means that some lawyer has been inadequate to his duty. Such a doctrine cannot come into being except through a misunderstanding of principles and an acceptance of insufficient reasons. At some point in our legal history, therefore, attorneys have not been competent to protect their clients, or judges have rendered judgment upon insufficient knowledge." I should modify his statement only in this respect, that attorneys have been competent enough, but did not apply sufficient diligence to their work. It is a fine call to the American Bar that Ab. bot makes: "We, who inherit a detailed body of jurisprudence, are not adequate to our duty, either as practicing attorneys or as members of the judiciary, if we fail to correct these errors."

As I have pointed out later on, the modern courts are increasingly ready to correct judicial error if the Bar but make adequate presentation of the error.

Of course, a study like the one embraced in the succeeding chapters cannot be made within the limit and scope of the ordinary brief. Indeed, the form of the ordinary brief does not permit of such a presentation. Moreover, appellate courts are not receptive to treatises or legal essays garbed in the form of a lawyer's "Brief." Perhaps it is right that this should be so. The careful, painstaking analysis of legal authority and legal principle must be done when the telephone bell is not ringing and the calendar is not too crowded. There must be time for reflection and criticism. Quite apart from these considerations, mere argument in one case or in one State would hardly serve to correct the existing viewpoint of both Bench and Bar. Furthermore, whatever information is secured for use in the courts of New York State should be made available to the lawyers of the entire country. It is these considerations that led to the publication of this work. "“Justice and the Modern Law," p. 79. 
Rusy lawyers, alas, rarely get time from active practice for such an interesting study as this one has proved to be the ragged edges in this work are due to the interruptions that come inevitably whon one is engaged in the active daily practice of the law.

I should be most ungrateful if I left the introduction without making simple acknowledgment to those who have helped me. First of all, to Mr. Lewis, whose case furnished the oceasion for the investigation, and who not only yraciously turned over to me all the material he had gathered together, but who has been of invaluable assistance in eheeking up and running down modern authorities as well as in correcting the proof. The librarians at the Economies Division of the New York Publie Library and at the Association of the Bar, especially Miss Adelaide R. Hasse, Mr. Franklin O. Poole and Mr. A. S. MeDaniel, have been of great help. My former assistant, Mr. Frank deR. Storey, was of invaluable aid to ne in the searehing through of old Year Books and the still older authorities, with his rare linguistic ability translating from the hard "eommon law French" into English, and helping me in nany other ways. I regret exceedingly that he was called to ot lier work before I could complete the manuscript. I am indebted, too, to Miss Winifred Notman, ${ }^{8}$ whose splendid legal attainments mabled her to save me from error in the manuseript, although she was unable, because of her acceptance of a call to war service in France, to complete her work. Without the assistance of my secretary, Miss Anna B. Deringer, it would have been impossible for me to have gotten out the book within the limitations of time.

Of course, it would have been impracticable for a practicing lawyer to have done this work if men of seholarly attainnent, like Naitland and Pollock and Ames and Pound and the others to whom reference is freely made throughwit the bowk, had not put their valuable contributions at the disposial of all legal students. In this connection, in

- (Num Mra. Uavid Cbaudler l'rice.) 
NRTODUC'TON xvii

view of the greater plaee women are coming to occupy in the affairs of the world, I like especially to mention the splendid contribution of Margaret Klingelsmith in her translation of Statham's "Abridgement" - a most scholarly contribution to the science of the law.

Juhiug Henry Cohen. 


\title{
CONTENTS
}

\author{
PART I \\ Public Polict
}

CBAPTER

PAGE

I. Business Men's Tribunals and the Law . . . 1

II. The Prevention of Unnecessary Litigation . . 10

III. Public Policy and Commercial Arbitration . $\quad 24$

IV. The Judicial Rule of Stare Decisis . . . $\quad 39$

\section{PART II}

The Doctrine of Revocability-A Judicial Error

V. Analysis of the English Authorities . . . .

VI. The Slow Emergence of Legal Concepts of Contractual Obligations . . . . . . 60

VII. The Conflict between the Law Merchant and the Common Law . . . . . . . . . . . 71

VIII. Coke's Dictum in Vynior's Case . . . . . 84

IX. The Earlier Precedents Contra to Coke's DicTUM . . . . . . . . . . . . . 103

X. The Effect of Coke's Dictum . . . . . 128

XI. Wherein Lord Coke's Dictum is Not Followed 142

XII. The Passing of Fines and Penalties . . . . 148

XIII. "Ousting the Courts of Jurisdiction" . . . 153

XIV. The Error is Corrected: Scot't v. Avery, 1855170

XV. The True Interpretation of Scott v. Avery (1855-94) . . . . . . . . . . . . . 180

XVI. The Judicial Correction of a Judicial Error (ENGLAND, 1853-1916) . . . . . . . . . 205

XVII. How English Error Worked into American Law 226 XVIII. The Development in the Federal (U. S.) Courts 242 xix 


\section{PART III}

\section{The Sounder Doctrine}

CHAPTER

XIX. Tile Court's Jealousy of its own Jurisdiction

XX. The Ordinary Understanding of an Arbitration Clause . . . . . . . . . . . . . 265

XXI. Conclusion . . . . . . . . . . . . 279

\section{APPENDIX}

A. Rules for the Prevention of Unnecessary Litigation (Report of Joint Committee of ChamBer of Commerce of the State of New York and of the New York State Bar Association)

B. Rules and Regulations of the Chamber of ComMerce of the State of New York for Submissions to Arbitration . • . . . . . 288

C. Illinois Law of Arbitration . . . . . . 294

D. Foril of Arbitration Agreement Adopted by the Public Service Commission for the First District of the State of New York with the Interborough Rapid Transit Company of New York . . . . . . . . . . .

E. Arbitration Provisions of United States Shipping Board Charter-Bare Boat Form . .

F. Rules of the Municipal Court of Chicago GoverNing ARBItration . . . . . . . .

G. Form of Submission to Arbitration used in the Munictpal Court of Chicago . . . . 302

H.' List of Organizations in Chicago agreeing to Promote Trade Arbitrations . . . . . 303

I. Rules for Arbitration now in Operation in the Municipal Court of the City of New YORK . . . . . . . . . 


\section{COMMERCIAL ARBITRATION AND THE LAW}

\section{PART ONE-PUBLIC POLICY}

\section{CHAPTER I \\ BUSINESS MEN'S TRIBUNALS AND THE LAW}

IN two trenchant articles written by a former judge, now counsel to the Public Service Commission for the First District of New York State, ${ }^{1}$ based upon a comparative study of the disposition of questions of fact by quasi-judicial bodies like the Public Service Commission and the disposition of such questions by existing judicial methods in the courts, the writer says that " "Business men have no great quarrel, as a rule, with the legal concepts which the common law, as modified by statute, would apply to the arbitrament of their business dealings; they wish, and need, certainty and equality as the underlying bases of their activities; they wish, and need, to know that when they do a certain thing in a certain way or enter into an agreement in a certain form, their rights and liabilities will be so-and-so, definable and ascertainable in advance." "But," on the other hand, says Judge Ransom, "for the court as a mechanism for promptly, acceptably applying that acceptable standard, the business man has today an

1"The Organization of the Courts for Better Administration of Justice," by William L. Ransom, 2 "Cornell Law Quarterly," pp. 186 and 261.

${ }^{2}$ Pp. 264-265. 
instinctive distrust and dislike; legal procedure is too complicated, technical, indirect, dilatory, wasteful of his time and everyone else's, to warrant him in taking any avoidable chances with the judicial mill." ' What business men want, says the author, "is a speedy determination of the facts, and then a prompt determination of their rights under the facts as found and the applicable rules of law, as commonly observed in the community for the conduct of similar business dealings.'" 4 An English writer, reviewing the development of English legal institutions, ${ }^{5}$ says: "Owing to the exigeneies of trade, merchants, of all men, require that the law should be known with precision."' "For eight hundred years merchants have cried for speedy justice. Mercantile men must be about their business, for trade will not wait. Once, the merchant was here today and gone tomorrow; now, he will sooner cut his loss than have his case hung up indefinitely ; if le cannot get king's justice he will go to arbitration." 7 Ex-Senator Root, in an address entitled, "The Layman's Criticism of the Lawyer," made before the American Bar Association at its meeting in Washington in 1914, said:

"American procedure ought to follow as closely as possible the methods of thought and action of American farmers and business men and workmen. The law is made not for lawyers but for their clients, and it ought to be administered, so far as possible, along the lines of laymen's understanding and mental processes. The best practice comes the nearest to what happens when two men agree to take a neighbor's decision in a dispute, and go to him and tell their stories and accept his judgment. Of course all practice cannot be as simple as that; but that is the standard to which we ought to try to conform rather than

" Cornell Law Quarterly," p. 265.

- Itid., p. 273.

" A History of English Legal Institutions," by A. T. Carter.

- Ibid., p. 265.

'Itid., p. 269. 
the methods of an acute, subtle, logical, finely discriminating, highly trained mind. It is that sort of thing which merchants seek when they get up committees of arbitration to decide their controversies without the intervention of lawyers. They are trying to get their questions settled in accordance with their instincts and habits of thought. That is the way in which all the great international arbitrations are conducted. Fortunately for them, the judicial procedures of the nations differ so widely that there cannot be any particular rules of practice in an international case. Accordingly each country tells its story in print and then both go in and tell the arbitrators about it. Many of these cases are exceedingly complicated and difficult but they require no complicated and difficult procedure." 8 "For contracts and injuries done concerning the fair or market," says Coke, " "there shall be as speedy justice done for the advancement of trade and traffic as the dust can fall from the foot, the proceedings there being 'de hora in horam." "The Carta Mercatoria of the reign of Edward I granted as a favour to foreign merchants that 'every contract between said merchants and any persons, whensoever they may come, touching any kind of merchandise, shall be firm and stable, so that neither of the said merchants shall be able to retract or resile from the said contract when once the God's penny shall have been given and received between the parties to the contract" "; ${ }^{10}$ and similar words were found in the Custom of Avignon. ${ }^{11}$ In this charter we find the words: "Item, volumus et concedimus, quod aliquis certus homo fidelis et discretus London, residens assignetur Justiciarius Mercatoribus memoratis, coram quo valeant specialiter placitare et debita

${ }^{8}$ Report of American Bar Association, Vol. 39, p. 397.

' 4 Institutes, 272, quoted in Smith's “Mercantile Law," Vol. I, Introduction, Ixxii.

${ }^{10}$ Smith's " Mercantile Law,", Vol. I, Introduction, lxxiv.

${ }^{11}$ Maitland's "Select Pleas in Manorial Courts," p. 133 (Selden Society). 
sua recuperare ccleriter, si vicecomites et majores eis non facerent de die in dicm celeris justicia complementum; et inde fiat commissio cxtra cartam prescntem concessa mercatoribus antedictis, scilicet de hiis quxe sunt inter mercatores et mercatores, secundum legem mercatoriam, deducenda."12 Sir Leoline Jenkyns says: "Nothing can be more pernicious to seafaring and trading men than delays in their lawsuits, and therefore every maritime country in Christendom has a separate judicature for differences among merchants and seafaring men. . . ."'13 The institution known as the "Gild Merchant" was an association for the purpose, among others, of mutual arbitration. Carter tells us:" "Members of the same gild were bound to bring their disputes before the gild before litigating the matter elsewhere." He tells us that this function of the gild merchant was "recognized by the kings." The great Gild of St. John of Beverley of the Hans House held charters from the Archbishop of York, with the royal license of Henry I, granting to the town and burgesses a gild merchant and the right of holding pleas among themselves, and that this grant was confirmed by an inspeximus charter of Richard II in 1379. The City of York has a eharter of John, dated 1200, giving a gild merchant the liberties pertinent $;^{15}$ and in 1581 the Queen allowed the merchants there to eleet a governor

\footnotetext{
12 Smith's “Mercantile Law," Vol. I, Introduction, Ixxiv, Ixxv, quoting I'rynne's "Animadversions," p. 23.

(Item, We ordain and grant that some certain loyal and discreet man residing in London shall be aprointed judge from amoug the well-known merchants, before whom it shall be lawful speeially to plead and quickly to recover their debts, if the sheriffs and elders shall not do for them a complete measure of quick justice from day to day; and to that end, let a commission under the present charter be granted to the aforesaid merchants, to wit, a charter for deciding those questions which arise between merchants and merchants, according to the law merchint.)

is "Life of Sir L. Jenkyns," Vol. I, Ixxsi. (Smith, Vol. I, Introduction, lxxvi.)

“ "History of English Legal Institutions," p. 268.

«s Gross: "The Gild Merchant,"' Vol. II, p. 279.
} 
and eighteen assistants, with power, inter alia, to try all suits among its members or between the latter and others. ${ }^{16}$ "In a charter to the eity of London ( 52 Hen. III) it is granted to the citizens not to plead without the walls, except (inter alia) to pleas concerning merchandise, which are wont to be decided by Law Merchant in the boroughs and fairs by four or five of the citizens there present." 17

In 1647 there was established in the Town of New Amsterdam, afterward New York, a court of arbitrators which was called "The Board of Nine Men," under an ordinance that provided for the appointment of nine arbitrators who should serve in rotation, three at a time, one arbitrator being a merchant, one a burgher, and one a farmer. The ordinance contained the following: "whereas in consequence of the increase of the Inhabitants, Lawsuits and disputes which parties bring against each other, are multiplied, and also divers questions and quarrels of trifling moment, which can be determined and disposed of by Arbitrators, but, in consequence of matters of greater importance, frequently remain over and undecided, to the prejudice and injury of this place and the good people thereof, and also to the great expence, loss of time and vexation of the contending parties...," three out of those chosen as arbitrators are required to attend "once a week, on Thursday, the usual Burgher Court Day to our General Council," and further provided that "parties referred, being judged shall remain bound to submit without opposition to the pronounced decision" 18 of the arbitrators. This board of arbitrators continued until 1653, the time when a municipal form of government was granted to New Amsterdam, and there was then created the Court of Burgomasters and Schepens. The citizens of New Amster-

10 Ibid., Vol. II, p. 280.

"Carter, p. 268, note 4, citing Norton, Comm. 416.

${ }^{20}$ Edgar J. Lauer: "The New Practice and Procedure in the Municipal Court of The City of New York," p. 5 (1916). 
dam were permitted to elect one Schout (Sheriff), two Burgomasters (Mayors) and five Schepens (Aldermen). This court continued during the remainder of the Dutch rule, and by proclamation of Governor Nicolls on June 12, 1665, when the town came under English sovereignty, it became known as the Court of the Mayor and Aldermen, or Mayor's Court; and later, when New York became an independent State, it became the Court of Common Pleas for the City and County of New York. In 1874 the Legislature created ${ }^{19}$ within the City of New York the office of "Arbitrator of the Chamber of Commerce of the State of New York," and the following year fixed ${ }^{20}$ the salary at ten thousand dollars a year. Though no salary was appropriated immediately, in the year 1878 twenty thousand dollars, representing two years' salary, was appropriated ${ }^{21}$ for the arbitrator and six thousand dollars for a clerk. This act repealed the provision for the salary of the arbitrator and clerk. The court was opened for business on the 15th of October, 1874, and continued to sit until the year 1881, though no provision had been made for the compensation of an arbitrator subsequent to 1878; and until his death Enoch L. Fancher acted as judge of that court, serving without compensation. The laws providing for the establishment of the tribunal have never been repealed. ${ }^{22}$

Judge Lauer, speaking of the $\Lambda$ rbitration and Conciliation Branch of the Municipal Court now existing pursuant to the recent amendment of $\$ 6$ of the Municipal Court Code, permitting that Court "to provide systems of conciliation and arbitration and to enter judgment upon an award of arbitrators," says that this branch of the Court "will be a place to settle disagreements, not to fight them out. It

${ }^{19}$ L. 1874 , e. 278.

$\infty$ L. 1875 , c. $495, \S 6$.

r. 1878 , c. 252 .

${ }^{22}$ See further upon this subject, Chapter xxi, post. 
will not only save time and money; it will save fighting. If it doesn't always bring exact justice, it will often bring something better. It will bring a friendly understanding, a thing almost impossible at the end of a contested suit." ${ }^{23}$ In a report made in the reign of Henry II on the customs of Newcastle on Tyne as they existed during the reign of Henry I, the following sentence appears:24 "Inter burgensem ct mercatorem si plucitum oriatur, finiatur ante tertiam refluxionem maris," indicating a mercantile court doing speedy justice. And again, in the Doomsday of Ipswich, drawn up in the nineteenth year of Edward I, a recension of the old book of the second year of John, it is stated that whereas pleas between persons sitting and dwelling in the town should be pleaded "by two days in the week," the merchant stranger is treated with the greater consideration which seemingly was everywhere shown to him:-

"The plees betwixe straunge folk that men clepeth pypoudrous, shuldene ben pleted from day to day. ... The plees in tyme of feyre betwixe straunge and passant shuldene bene pleted from hour to hour . . . and the plees yoven to the lawe maryne, that is to wite, for straunge marynerys passaunt and for hem that abydene not but her tyde, shuldene been pleted from tyde to tyde."

Baldasseroni says concerning arbitration: "By this mode of settling disputes, law-suits are nipped in the bud, the restraints of forms of process are thrown aside, and the mind of the merchant is not distracted from his own business by the conduct of the suit." ${ }^{25}$ Bell ${ }^{26}$ comments upon the statute 13 and 14 Vict. c. 36 , by which provision was made $(\S 50)$ to enable parties to agree by mutual

Lauer, p. 73.

Carter, p. 269.

* Delle Assicurazioni Maritt.: Del Tratt. dell' Avar. T. 10, Dei Giudizj, sec. 38. Ed. Firenze, 1786, Tomo III, p. 154. (Quoted by Bell: "Law of Arbitration in Scotland," p. 6.)

${ }^{2}$ Bell: "Law of Arbitration in Scotland," p. 14. 
consent, in any case before the Court of Session in which an issue was to be tried, to have it tried before one, three, five, or seven arbitrators, sworn and sitting as a jury. "It was declared," says he, "that the sole arbiter,-or, where there were several arbiters, a majority of their number,should have all the powers of a unanimous jury. It was apparently intended by this means to afford one method of supplying what is still so much wanted in jury trial; the pouer of selecting a tribunal, composed of persons who are specially fitted, by experience or otherwise, for dealing with the particular question to be tried,-such as a jury of merchants to try a mercantile question arising among partners; or the like." 27

The London Times in an editorial in 1891 (May 8), at a time when the relative value of judicial disposition of commercial controversy as compared with arbitration by business men was under public diseussion, said:

"Long before 1883 there had grown up a class of arbitrators who, with all their shortcomings, were expeditious and acquainted first-hand with the subjeet-matter in dispute. All their lives they had handled the cotton, wool, or seeds over which the parties were quarreling. They had written, made advances, bought and sold upon the documents, the construction of which was in question. They had obeyed, perhaps helped to form, the trade customs to which the disputants appealed. That class of experts has inereased. Their skill has grown with experience, and it is altogether too late to think of ousting them."

And Mr. Rosenbaum, a modern student of the subjeet, says in his "Report on Commercial Arbitration in England" (made for the American Judicature Society, Bulletin XII): "What was true in 1891 is even more true in 1916, and every business bas its expert arbitrators, generally older and seasoned veterans who were in the thick of the fight for years and retired to make way for the

"Italics ourg. 
younger men." ${ }^{28}$ In the Chamber of Commerce of New York, the Committee on Arbitration reports that "The simple, genuine confidence with which the business man approaches your Committee and submits his troubles is very marked. While he may not always get the award that he expects, any more than he may always realize his expectations in a lawsuit, those who have used our facilities have been (with but possibly one exception) satisfied with the awards of the arbitrators. There has been no case as yet in which resort to the courts has been necessary to enforce an award." ${ }^{29}$

${ }^{23}$ American Judicature Society, Bulletin XII, by Samuel J. Rosenbaum, p. 53 .

${ }^{20}$ Report of the Committee on Arbitration, 1917. 


\section{CHAPTER II}

THE PREVENTION OF UNNECESSARY LITIGATION

ENDORSED upon the pamphlet printed and distributed by the American Bar Association, eontaining the Canons of Ethies for the conduct of the Bar, appears this quotation from Lincoln: "Discourage litigation. Persuade your neighbors to eompromise whenever you can. Point out to them how the nominal winner is often a real loser-in fees, expenses and waste of time. As a peacemaker, the lawyer has a superior opportunity of being a good man." Recently the lawyers of the State of New York have taken this injunction very much to heart. The Committee on Prevention of Unneeessary Litigation was ereated by the State Bar Assoeiation in 1914. In 1917, in an exhaustive report, it referred to the system of commercial arbitration existing under the rules of the Chamber of Commerce of the State of New York and said eoncerning its own plan: "The proposed by-law and rules are modeled after those of the New York Chamber of Commerce, which has maintained a system of arbitration almost continuously for more than a hundred years." The eommittee recommended that the State Bar Association supplement the facilities of the Chamber of Commeree by providing an official list of arbitrators made up of members of the Bar. Earlier, and in 1914, Perey Werner, a member of the St. Louis Bar, wrote eoncerning the desirability of lawyers as arbitrators: ". . where parties having a private disagreement which they are mable to settle resort to lawyers who are likewise unable to bring about an accord and satisfaction, these lawyers shall elert from among their fellow-members 
of the bar a judge before whom to try their case, following the statutory form for arbitrations. Their agreement of submission, stating the subject matter of the controversy, with, of course, sufficient certainty that it can always be used in support of proof of res adjudicata, constitutes the only pleading in the case. Mere matters of procedure, as to time, place and manner of trial, are regulated by the attorneys and arbitrator, or controlled by the latter, as may best suit the convenience of all concerned." At the 1916 session of the New York State Bar Association, the committee was authorized to negotiate with the Chamber of Commerce for the adoption of "Rules for the Prevention of Unnecessary Litigation." As a result of these efforts, there was jointly prepared and is now circulated a printed pamphlet entitled "Rules for the Prevention of Unnecessary Litigation," 1 among which is included the following advice (under the heading "Prevention of Litigation after the Facts Become Fixed and before Suit"):

"After the facts upon which a dispute can be based have become fixed, either before or after a dispute has arisen, it is possible to do much to prevent litigation. What can best be done in each case and whether with or without legal advice, necessarily depends upon the facts and the parties to the prospective controversy. Differences may be minimized, adjusted or arbitrated. If not so disposed of, litigation will usually ensue."

Arbitration.- "Where differences cannot be adjusted between the parties or their attorneys and the intervention of a third party becomes necessary, there are several forms which arbitration may take. The arbitration may be (1) informal, (2) under the Code, (3) under the auspices of a commercial body, or (4) under the auspices of a bar association.

"The experience of many business men and lawyers tes-

${ }^{3}$ See Appendix A. 
tifies to the advantage of these methods of adjusting differences wherever possible. They are inexpensive, speedy ani peaceful."

From this brief survey of the official activity of the Bar of the State of New York, it will be seen that it is made the affirmative duty of members of the Bar to avert the clashes, the bitternesses and the waste of litigation. It is regarded as a high virtue to settle a eontroversy without suit or by arbitration, if it can be done. Nor is this movement confined to the Bar of New York State. In an article appearing in the London Law Journal, entitled "Lawyers and Conciliation," it is stated: " "Both in external and internal affairs the movement for the peaceful settlement of differences is making remarkable' progress before our eyes."

How, then, ean it be argued that it is part of the duty of the Court to prevent parties from settling their controversies in any manner they choose? As a matter of fact, the Court is assiduous to enforee releases unless they have been proeured through fraud or mistake. In disposing of accounts stated, the Court is exceedingly reluetant to disturb adjustments that have been made, yet by virtue of such settlements or exchange of releases sometimes grave questions of law are kept from determination by the Court-often questions, the determination of which would eontribute mueh to the comprehensive development of the common law. From the point of view of soeiety, in some instanees it might sometimes be better to secure a determination of the partieular question of constitutional or other law involved; yet this eonsideration has never prevailed with the Court, nor resulted in the rejection of an adjustment or a settlement of the controversy, with the eonsequent waiver and elimination of an interesting and perhaps important question of law.

'44 London Law Journal (Feb. 20, 1909), p. 114. 
Judge Allen, speaking for the Court of Appeals, ${ }^{3}$ said, in 1872 , that the rule permitting revocation of submissions to arbitration owes its origin in large measure to an aversion of the courts, "from reasons of public policy, to sanction contracts by which the protection which the law affords the individual citizens is renounced." But Judge Allen went on to say that "The tendency of the more recent deeisions is to narrow rather than enlarge the operation and effect of prior decisions, limiting the power of contracting parties to provide a tribunal for the adjustment of possible differences, without a resort to courts of law." "The better way, doubtless, is to give effect to contracts, when lawful in themselves, according to their terms and the intent of the parties; and any departure from this principle is an anomaly in the law, not to be extended or applied to new cases unless they come within the letter and spirit of the decisions already made." 5 A recent Pennsylvania court (1913) held ${ }^{6}$ that the constitutional guarantees of liberty and property forbid the Legislature to declare invalid any clause in a contract whereby an arbitrator's award is made conclusive of the rights of the parties thereunder. The Court holds that freedom of contract may not be abridged except in the interest of good morals or the welfare of the general public, and that the statute in question promotes neither of these ends. In a note discussing the decisions defining the scope of the legislative power to limit freedom of contract it is said that " "The best considered decisions overthrowing legislation as repugnant to the due process clause recognize a police power as broad as this (protecting citizen against himself as well as to shield him from acts of others), but

- Delaware, etc., Canal Co. v. The Pennsylvania Coal Company, 50 N. Y. 250 , at p. 258.

- Ibia., p. 259.

I Ibid., pp. 258.259. Italics ours.

- Adinolfi v. Hazlett, 242 Pa. 25,88 Atl. 869.

'27 Harvard Law Review, p. 374. 
hold that the constitution declares a strong public policy in favor of letting every citizen work out his own salvation, and that his power to do so should not be impaired except when necessary to correct an evident existing evil." And a recent writer on "Public Policy" says :

“(1) In general any contract made by a competent party, upon valuable consideration, when made freely and intelligently, is valid," unless (2) it "bind the maker to do something opposed to the public policy of the State or Nation, or confliets with the wants, interests, or prevailing sentiment of the people, or our obligations to the world, or is repugnant to the morals of the times," then "it is void, however solemnly the same may be made." 8

"By 'public policy' is intended that principle of the law which holds that no subject can lawfully do that which has a tendeney to be injurious to the public or against the public good, which may be termed the policy of the law, or public policy in relation to the administration of the law." 9

It has long been settled that the prevention of litigation is a valid and sufficient consideration for the settlement of a controversy; "for the law favors the settlement of disputes." ${ }_{10}$

"No investigation into the character or value of the different claims submitted will be entered into for the purpose of setting aside a compromise, it being sufficient

${ }^{8}$ Greenhood, "The Doctrine of Public Policy in the Law of Contracts," p. 1 .

${ }^{9}$ Ibid., p. 2. Sce Egerton v. Brownlow, 4 H. L. C. 1.

See arbitration cases: Nute v. Ilamilton Mut. Ins. Co., 6 Gray 174; Tobey $v$. The County of Bristol et al., 3 Story 800, 821.

"Parsons, "Law of Contracts," Vol. I, p. *438. See Penn v. Lord Baltimore, 1 Ves. Sen. 444; Wiseman v. Roper, 1 Chanc. 158; Barlow v. Ocean Ins. Co., 4 Met. 270; Stapilton v. Stapilton, 1 Atk. 3; Zone v. Zane, 6 Munf. 406; Taylor v. Patrick, 1 Bibb 168; Fisher ¿. May, 2 Bibb 448; Broun v. Sloan, 6 Watts 321; Stodalard $v$. Mix, 14 rom. 12; Pice v. Bixler, 1 W. \& S. 456. 
if the parties entering into the compromise thought at the time that there was a question between them." 11

So that we may conclude upon this examination of the subject that, just as it is the duty of the Bar to dispose of controversy amicably without resort to the courts, it is at this date an accepted doctrine of the common law that efforts, honestly made, by partics seeking to settle their differences out of court, are to be encouraged and enforced by the court; and that whatever may have bcen the influences affecting a different procedure in the past, in this day there is no disposition to guard with any jealousy "the jurisdiction of the courts.", 12 In a footnote to Corpus Juris ${ }^{13}$ the rule of revocation is called "a highly technical rule, and the enforcement of it against the purposes of parties who have sought a settlement of their disputes out of court by a tribunal of their own choosing has at times provoked protest from commonlaw judges."

Says Grier, J., in Fox $v$. The Railroad: ${ }^{14}$ "Such a clause in contracts like those constantly made by corporations for great public improvements, is absolutely necessary to prevent the corporations from being ruined by endless litigation. It should be liberally construed and not subjected to ingenious criticism in order to support the jurisdiction of courts of law and encourage litigation." 15

We shall examine the protest made in 1915 by Judge

${ }^{11}$ Parsons, "Law of Contracts," p. *439. Ex parte Luey, 21 E. L. \& E. 199; Mills v. Lee, 6 Monr. 91; Hoore v. Fitzwater, 2 Rand. (Va.) 442; Bennet v. Paine, 5 Watts 259; Picrson v. McCahill, 21 Cal. 122; Clark v. Gamuell, 125 Mass. 498; Flannagan v. Kilcome, 58 N. H. 443.

${ }^{12}$ Del., etc., Canal Co. v. The Pcnnsylvania Coal Company, 50 N. Y. 250; Judge Allen at p. 258 et seq.

${ }_{13}$ Vol. 5, p. 53, note 12 a.

143 Wall. Jr. 243, at p. 247.

${ }^{15}$ See also Monongahela Navigation Co. v. Fenlon (1842), 4 Watts \& Sergeant 205; Calvin v. Provincial Insurance Co., 27 Up. Can. Q. B. 403; Gricr v. Bilger, 13 Pa. 58 (1850); Snodgrass v. Gavit, 28 Pa. 221 (1857), and Appendiees $D$ and E. 
Hough, an honored member of the Federal Circuit Court of Appeals of the Southern District of New York, but as early as 1855 Baron Martin expressed his views as follows: "I regret that the law is so, and that the legislature, when they were dealing with the subject of arbitration, did not in all cases prohibit the revocation of references." Maule, J., is reported to have said: ${ }^{17}$ "The old rule upon whieh it was held that the power of an arbitrator was revocable, was, that a power not coupled with an interest, was revoeable,-revoeable by the authority which created it. From that rule it was inferred,-erroneously, as I think,-that one of the parties to a submission might revoke without the other. It seems to me that that was allowing one man to affect the interest of another. But it u'as an inveterate error." 18

It has been repeatedly held that parties may stipulate that the laws of another place or another country than the one wherein the contraet. is made shall govern its interpretation and remedy both as to the rights of the parties and their remedies in case of a breach. ${ }^{10}$ Parties may even by stipulation waive their right to appeal. ${ }^{20}$ There is strong authority, also, as we shall presently find, for the legal

is Mills v. Bayley, z.H. \& C. 36, 41.

${ }^{17}$ Northampton Gas-Light Co. v. Parnell, 15 C. B. 630, 645, 80 ECL 630, 139 Fnglish Reprint 572.

${ }^{18}$ Italies ours.

${ }^{10}$ See MeAllister v. Smith, 17 Ill. 328, 334; Union National Bank v. Chapman, 169 N. Y. 538, 545; Grand v. Livingston, 4 App. Div. $589,593,596$, affirmed 158 N. Y. 688; Dike v. Frie Railway Co., 41 N. Y. 113, 116; Le Breton v. Milles, 8 Paige 261; Grecr v. Poole, L. R. 5 Q. B. D. 272.

${ }^{2}$ Tounsend $v$. Masterson, 15 N. Y. 587;O. \& L. C. R. R. Co. v. V. \& C. R. R. Co., 63 N. Y. 176; Godfrey v. Mfoser, 66 N. Y. 250; Riggs v. C. Mf. Ins. Co., 125 N. Y. 7; Palmer v. Lavers, 105 N. E. 1000 (Mass. Supreme Jud. Ct. 1914); Hoste v. Dalton, 137 Mich. 522 ; Watson $v$. Wetter, $91 \mathrm{~Pa}$. 385. Contra Muldrow v. Norris, 2 Cal. 74; Fuhs v. Darling, 82 Ill. 142; Bank v. White, 220 Mo. 717, 736.

See also People v. Stephens, 52 N. Y. 306; Riggs v. C. M. Ins. Co., 125 N. Y. 7 (25 N. F. 1058, 10 L. R. A. 684, 21 Am. St. Rep. 716); Rogers v. Playford, 12 Pa. 181. 
proposition that parties may select the courts in which the ease is to be tried in the event of controversy between them. Though this has been controverted, much the better authority supports the view. ${ }^{21}$ Judge Parker, in the case of La Greve $v$. Atna Live Stock Insurance Co., ${ }^{22}$ said: "The suggestion that the Court should resent this attempt to oust it of jurisdiction is unworthy of extended notice"; and a great English judge (Jessel, M. R.) said: ". . . if there is one thing which more than another publie policy requires it is that men of full age and competent understanding shall have the utmost liberty of contracting, and that their contracts when entered into freely and voluntarily shall be held sacred and shall be enforced by Courts of justice." 23 So, also, the late Judge Earl of the New York Court of Appeals said: "Parties by their stipulations may in many ways make the law for any legal proceeding to which they are parties, which not only binds them, but which the courts are bound to enforce." 24 This superb policy of the law is illustrated in many ways. The parties to a contract may require the commencement of an action within a period shorter than that required by Statutes of Limitations and thus make their own Statute of Limitation. ${ }^{25}$ They may limit their

${ }^{2}$ See "The Legality of Contracts Affecting the Jurisdiction of Courts,"' by G. B. Slaymakor, 58 Cent. L. J. 64, 65; Mittenthal v. Mascagni, 183 Mass. 19; Austrian Lloyd Steamship Co. v. Gresham Life Assurance Society, L. R. [1893] 1 K. B. D. 249 (see also post, p. 217) and brief of Walter H. Pollak in Engel v. Shubert Co., N. Y. Supreme Court, App. Div., 1st Department, 166 App. Div. 394, V. 3071 Bar Association Reports.

281 Hun 28, at p. 30 .

${ }^{2}$ Printing and Numerical Registering Co. v. Sampson, L. R. 19 Eq. 462 , at p. 465 .

is Matter of N. Y., L.\& W. R. R. Co., 98 N. Y. 447, at p. 453.

${ }^{25}$ Erie R. R. Co. v. Stone, 37 Sup. Ct. Rep. 633; Ames v. N. $Y$. Union Ins. Co., 14 N. Y. 253, 262; Ripley v. Aetna Ins. Co., 30 N. Y. 136, 163; Roach v. N. Y. \& Erie Co., 30 N. Y. 546; Mayor of New York v. Hamilton Fire Insurance Co., 39 N. Y. 45; Wilkinson v. First National Fire Insurance Co., 72 N. Y. 499; Ketchum $v$. Belding, 58 App. Div. 295; Clemens v. American Fire Insurance Co., 
liability for negligence ${ }^{26}$ and may, indeed, provide an exclusive form of remedy which the courts will enforce. ${ }^{27}$

IIerbert Harley, Secretary of the American Judicature Society, in an introduction to Bulletin XII issued by his Society in October, 1916, says: "The present universal fear of litigation, with its slow and costly procedure and interminable appeals, is a principal reason for this irregular method of reaching a settlement-for it ought not to be dignified by the name of arbitration. Its fault is not merely that of inexpertness but that it is dominated by compulsion, not by mutuality. Arbitration is the means by which this growing function is to be methodized and regulated in a public manner. It should be viewed, not as hostile to courts but as a special method of adjudication adapted to certain modern needs, a new arm of the law supplementing courts in a practical way."

This Bulletin is itself an illustration of the growing tendency of the American Bar to treat arbitration as a necessary and important means for securing justice without resort to the courts. As Mr. Harley says:

"New ways of living and transacting business imply new machinery in the law. Society is eonstantly devising new tools to accomplish its work more economically. Commercial disputes, aside from their technical nature, are different in an essential way. In the law the rendering of exact justice in the matter presented is a final aim. But in business the settlement of a given dispute is not the most important thing. The big thing is the relationship between the parties. In its formal tribunals the

70 App. Div. 435; Williams v. Fire Association of Philadelphia, 119 App. Div. 573; Riddlesbarger v. Hartford Insurance Co., 7 Wall. 386 (collecting authorities); Fullam v. N. Y. Union Insurance Co., 7 Gray 61.

${ }^{20}$ Andersom v. Erie R. R. Co., 171 App. Div. 687.

${ }^{27}$ See Hickman $v$. Sauyer, 216 Fed. Rep. 281 and cases cited. 
law must ignore this preservation of relations between the parties, however momentous.

"The essential difference appears to be that compulsion is the central feature of judicial procedure, while mutuality and voluntary submission underlie arbitration, giving it validity and afiording a basis for successful continuance of business relations. Arbitration is thus seen as a constructive social function weaving into the fabric of commercial life to strengthen rather than sever its threads."

To encourage and widen the field of arbitration, the Society engaged Samuel G. Rosenbaum, of the Philadelphia Bar, to make a study of Commereial Arbitration in England. Mr. Rosenbaum, after seven months in 1915, made his report, which the Society published as Bulletin No. XII.

Space will not permit free quotation from this valuable document. But the following references will give some indication of the very general use to which arbitration is now put in England.

"Efficient though the English courts are in disposing of all but 3 per cent of their great volume of business without letting it come to trial, there is a large mass of disputes in mereantile and other matters that is never bronght into the duly constituted courts of law at all. These disputes, instead of forming the basis of lawsuits, are, for a variety of causes, and in a variety of modes, submitted to arbitration, and there has grown up in England a law, practice and custom of arbitration, which is daily growing in bulk and authority and may almost be said to amount to a system of jurisprudence in itself.

"The greatest impetus to the spread of arbitration in England was due to the American Civil War.

"During and after that conflict there was an enormous number of disputes between eotton shippers and traders in the South, on one side, and the factors in the Liverpool 
cotton market on the other, ranging from differences over liability for war risks to the condition in which shipments of cotton were arriving in the Mersey. So many arbitrations were taking place at that time in the Liverpool market that the Liverpool Cotton Assoeiation, an organization eomposed of brokers and buyers in the trade, set up an Arbitration Committee to pass on all questions in dispute and the members inserted in all their contracts a clanse requiring disputes to be submitted to the Arbitration Committee of their Association. The suceess of the plan strengthened the position of the Association in the trade, and that, in turn, increased the power of the Arbitration Committee so that praetically every difference that arose in the Liverpool cotton market between buyers and sellers, whether English or foreign, came to the Arbitration Committee for settlement.

"Other trades were quick to see the advantage of this system of organized arbitration. The Liverpool Corn Trade Association soon established a similar committee, and then the General Brokers' Association followed suit. The London markets next took it up; the associations existing in the Corn Trade, the Oil Seed Trade, the Cotton Trade, the Coffee Trade, and others, set up their own arbitration committees, and year by year, other associations either adopted the plan or came into existence with trade arbitration as one of their avowed objects. The various exchanges all molded their committees on similar lines-the Stock Fxchange, the Coal Fxchange, the Produce Exehange, and others. Then professional bodies began to see the advantage of providing a medium for settling disputes at home instead of by strangers, and the Architects, the Engineers, the Estate Agents, the Auctioneers and other such groups established domestic tribunals."

The result is that "Today there is not a trade or professional organization in England that does not provide 
some means for the arbitration of disputes that arise among members or between members and others, and frequently between non-members engaged in similar work. It is not surprising, therefore, that by this means a great volume of litigation is avoided and commercial disputes kept out of court."

"In the Ineorporated Oil Seed Association the total number of arbitrations begun averages between 5000 and 6000 a year; roughly one-half of these are settled or withdrawn without going further."

"In the London Corn Trade Association arbitrations to the extent of 2000 a year are commenced, and the appeals run from 100 to 300 a year; but there are seldom more than two or three cases stated in a year. In the London Oil and Tallow Trade Association about 150 awards are filed each year (which would mean more than that number of arbitrations commenced) and against those about 15 appeals a year are taken."

"In the London Jute Association there are 1200 arbitrations commenced in a year. ..."

"In the Refined Sugar Association (which is confined solely to Continental refined sugar) there are about 60 awards a year. ...."

"The Dried Fruit Trade Association has about the same number and pursues the same poliey with regard to stating a case. There are many associations, such as in the Cattle Food Trade, in which arbitrations run from a dozen to a hundred a year, out of which no ease has ever been stated to the courts."

"Since the war nearly all the associations have had occasion to state cases arising out of disputes over the 
effect of war on eontracts; questions of liability for total breach and inability to perform, questions of insurance and war risk at sea, questions arising out of the faniliar 'Restraints of Princes' clause in contracts, and questions arising out of the several international embargoes, have caused a flood of litigation in the City, which, eommencing in the arbitration rooms where the facts were definitely ascertained and disposed of, is now slowly working its way westward through the Lower Courts to the House of Lords."

"That the volume of arbitrations has been cousistently large in preceding years is borne out by the following phrases from legal jouruals for various dates:

"1901: "Commercial men are often heard to say that arbitration as a means of settling their many and varied disputes, is inninitely more satisfactory than recourse to ordinary legal tribunals.' (110 Law 'Times 257).

"1905: 'In most agreements entered into between parties nowadays, relative to commereial transactions, we find the introduetion of an arbitration clause.' (118 Law Times 426).

"1909: "We have every reason to believe that the business in courts of arbitration-or as they are sometimes called, the irreg'ular tribunals-Iras largely increased.' (53 Solicitors' Journal 424)."

Mr. Rosenbaum gives us a reference to the 1913 volume of the Civil Judicial Statisties (Parliamentary Papers (1. 7267) in which Sir John Macdonell, the King's Renembrancer, says:

"The large and rapidly increasing number of disputes are determined by arbitration. Many trades have completely organized systems of arbitration for the settlement of disputes relative to quantity and quality of goods and as to the performance generally of mereantile contrarts. Many of the arbitrations are conducted informally and never come before the courts, or if they do, 
only upon applications under the Act of 1889 to enforce awards, or for the appointment of an arbitrator or umpirc.

"It is more and more the practice to introduce an arbitration clause into eontracts, with the result thai disputes are determined outside of the courts, no applications being made thereto, except occasionally, to stay proceedings brought contrary to the terms of such clause. I have endeavored to obtain some approximate figure as to the amount of disputes terminated in this manner, but the data requisite even for an approximate estimate are not accessible.

"There is very often a clause in contracts, particularly for the execution of works, that the engincer or arehitect of an employer is to be the sole and final judge in all disputes which may occur under the contract or as to its meaning; which may also mean the withdrawal from the court of disputes which would otherwise come before it." 


\section{CHAPTER III}

\section{PUBLIC POLICY AND COMMERCIAL ARBITRATION}

Nearly all of the writers on arbitration, in introductions to their volumes, have delved somewhat into the history of arbitration in all countries and in all times. Perhaps the best of these studies is to be found in Bell's "Iaw of Arbitration." Reference to almost any of the many works cited in our Bibliography will confirm the statements in this chapter. Aristotle quotes a passage from Arehytas in which he compares an arbitrator to an altar, as being a refuge for the injured. (Aristotle's "Rhetoric," Liber III, Chap. II.) At Athens there were two kinds of proceedings that were called arbitration. For instance, the Greek word for arbitration is diaeta. In one case the arbitrators constituted what is described in the "Penny Cyclopaedia" as a "Court of Reconcilement." "An appeal lay from their decision to the ordinary courts; and sometimes the arbitrator referred the cause to their judgment at once, without pronouneing any sentence of his own." 1 In the other class of proceedings the parties were free to refer their differences to whomsoever they chose. The submission was generally made by a written agreement, which often contained an engagement by third persons to become sureties for its performance. ${ }^{2}$ In these cases the arbitrator was not required to be governed by rigid applieations of the law, but was free to decide according to

1"Penny Cyclopaedia," Vol. II, p. 252, eiting Heraldi Animadver. siones, p. 372.

'Demosthenes' Speech against Apaturius, Chapter 4. 
the merits of the particular ease before him. ${ }^{3}$ But there was no appeal from his award to any other tribunal whatsoever. ${ }^{4}$ Bell says that both in ancient and modern times resort to the settlement of disputes by arbitration rather than by the intervention of courts of law has been had so often that it seems probable that the origin of "this amicable private tribunal is of an earlier date than the regular establishment of public Courts, and that Arbitration, in fact, took its rise in the very infancy of Society." s That whenever parties had a dispute that it was inconvenient to settle by force or violence, which nevertheless required a settlement, "Nothing seems more likely than that they should bethink themselves of the expedient of referring the question to some mutual friend, or neutral third party, as umpire between them, and agreeing to abide by his decision." 6 Bell regards the famous award delivered on Mount Ida by the royal shepherd Paris as one cause célèbre in the law of arbitration of a date so remote that it belongs to fabulous antiquity. (Arbiter es formo certamina siste Dearum-Ovid, "Heroid, Epist." xvi, 69.) And it is true that, as the story goes, upon the failure of all other means of adjudicating on the rights of rivals, both powerful and so excited, the parties agreed to a submission to Paris as sole arbiter, and thus speedily determined by final judgment a dangerous dispute, balking the Goddess Discord of her sinister aim." "Even after regular Courts

"Aristotle- "Rhetoric," I, 14.

See the law quoted by Demosthenes against Meidias, Chapter 26.

- Bell, p. 1.

Ibid.

" The introduction of arbitration seemed to be coeval with the foundation of our law;", per L. Pres. Blair, in MacCallum, etc., June 26, 1810 ; F. C. 'Lors des premières sociétés, les différends se jugeaient par les pères de famille: de là est vena le nom de tribunal patriarchal, donné à celui des arbitres. Le commerce, aussi ancien que le monde, n'avait point autrefois, pour ses faits civils et commerciaux, d'autre tribunal.', [English trans.: In the earliest forms of society, disputes were tripl by the heads of families, whence is derived the name of patriarchal tribunal, now given to the office of arlitrator. Commerce, as old as the world, in former times had for 
of law had been duly established," says Bell, " "and were so constituted as to command the respect and confidence of the community, recomrse to arbitration continued nevertheless to be frequent among many of the most civilised nations, at all periods of history.'

Bell attributes the frequent resort to arbitration as due to the fact that there are many questions "which, in their own nature, are best suited for the determination of a judge who is expressly seleeted by the parties themselves on aceount of his special fitness for trying cases of that particular class." 9 And as illustrations of these, he finds the purely mercantile questions, such as involve the examination of merchants' books and aecounts and "require an intimate practical acquaintance with commercial usages and affairs." "It can scarcely be doubted," says he, "that parties, having a dispute, would generally act with prudence in seleeting one or more mereantile men of experience, firmness, and impartiality to arbitrate between them." This is especially true where the serviees of experts are required. "In a public court," says he, "the judge or the jury would probably require the aid of sueh men, before disposing of eases like these." Why not let them be the arbiters? Then again, disputes which "turn on the opinion or professional knowledge of a practical engineer, a practieal shipwright, an architeet' -all of these eases make for the large and daily increasing group which fall under arbitration. "Besides, there are whole classes of cases in which, from special circumstanees-such as the near relationship of the antagronists, or the intimate confidence which has at one time subsisted between them, or the indelicate llature of the investigation whieh is in-

its civil and nercantile transactions no other form of tribunal.] (Bourher's introductory " Recherches,", etc., prefixed to his French trauslation of $1 /$ ronsolato del Mare. Paris, 1808. 'T. T, p. 3.)

"Bell, 1'. '..

Ibid. 
volved, etc.-it is best in every respect that the controversy should be conducted and decided before a private tribunal." 10 And in addition, he gives another important reason for the general acceptation of arbitration as a means of disposing of mereantile disputes in the delays and expenses incidental to procedure in court which are "unfortunately proverbial."

Among the Romans, the employment of arbitrators ad finiendas lites largely obtained from an early period. This appears not only from the mention made of arbiters in the law of the twelve tables and in various works, particularly Cicero's, but still more from the number of practical topies in arbitration. law which are treated of in that title of the Pandex which covers the subject. ${ }^{11}$ In France from an early period questions arising out of marine insurance contracts and questions arising out of partnership contracts were submitted to arbitration. By the royal Ordonnance (1673), Title IV, Art. 9, it was required that in every contract of copartnership there should be inserted a provision for the submission of certain classes of questions that might arise between the partners to the determination of arbitrators, and where this clause might have been omitted from any such contract the law implied or supplied such a provision. Furthermore, in order that submissions might not be avoided in certain classes of eases it was provided that if the parties were to name arbitrators and one of them failed to name an arbitrator, either at the outset or subsequently because of the death of an arbitrator before the close of a submission, the court was to name an arbitrator in the place of the party so failing. In the modern Code de Procedure Civil, an entire title is appropriated to the careful regulation of procedure in arbitration. In Scotland in 1695, Articles of

\footnotetext{
${ }^{10}$ Ibid., p. 3.

"Ibid., p. 6. [Lib. 4, T. 8. De receptis, qui arbitrium receperunt, ut sententiam dicant.]
} 
Regulation were passed, in which appears the following recital:

"That, for the cutting off of groundless and expensive pleas and processes in time coming, the Lords of Session sustain no reduction of any deereet-arbitral that shall be pronouneed hereafter upon a Subseribed Submission, at the instance of either of the parties-submitters, upon any cause or reason whatsoever, unless that of corruption, bribery, or falsehood, to be alleged against the judges-arbitrators who pronounced the same." 12 It was this act that in Scotland, as Bell tells us, "truly did little or nothing else than to restore the Contract of Submission to its native foree and vigour, and to secure for an arbiter's award that degree of conclusive finality, which it was the very object of both parties to confer upon it, when they originally entered into the contract." 13

In Denmark courts of arbitration or conciliation were established about 1795 and are said to have been attended with extraordiuarily beneficial effects. ${ }^{14}$ In towns other than Copenhagen, "the chief magistrate proposes five or six of the more respectable citizens for arbitrators, of whoin the commonalty of the town eleet two. . . All matters of eivil litigation may be referred to these official arbitrators. ... It appears that ... the arbitrators in these tribunals have no power to compel the parties to settle their differences ... they are at liberty to discuss their respective rights in the ordinary courts of justice. It is necessary, however, that before a suitor commences an action in the superior courts, he should prove that he has already applied to one of the courts of conciliation. These courts ... were .. multiplied rapidly in Denmark and Norway, and are said to have produced an astonishing decrease in the amount of contentious litigation. (See Tableau des

Bell, p. 13.

Tbid., p. 14.

"“Penuy Cyclopedia," Vol. II, p. 253. 
États Danois, par Catteau, tome 1, p. 296.)" "15 J. F. Archbold on Arbitration and Award writes: "The expense of an action or bill in equity, in comparison with the moderatc expense of an arbitration, would in ordinary cases induce parties about to be involved in litigation to choose the latter, if they can agree upon the appointment of an arbitrator well versed in the law or equity applicalle to the case, and upon whose honour they may depend that he will act impartially as a judge between them, and not as the partisan of either." ${ }^{16} \mathrm{Kyd}$ says: " "A conviction of the good policy of encouraging these domestic tribunals, has induced those who have presided over the formation of the civil code, to lend them their assistance to enforce obedience to their decrees." Writing in 95 Law Times, 524-528 (Oct. 14, 1893), H. Bentwitch says that during the whole existence of the Hebrew state in Biblical times "and even later on, during the period of exile, a system of arbitration was the sole mode adopted for the settlement of private disputes, the Beth Din (a chamber of arbitration, consisting of any three persons learned in the law) having cognisance of, and the right to decide, all such cases. It was," says Bentwitch, "indeed, a maxim that no man should be encouraged or assisted to litigate. ..." Bentwitch writes: "In the older Roman law there was no complete remedy for non-performance of the award, unless the parties bound themselves reciprocally either to perform what should be awarded or to incur the forfeiture of a sum of money or of some other specific thing. This, however, was remedied by Justinian, who enacted that, whether the submission was under a penalty or not, there should be no appeal after a lapse of ten days from the judgment, and each party should then have a remedy against the other based on the judgment in case

15 Ibid., pp. $253 \cdot 4$.

${ }^{16}$ Preface, p. $\nabla$.

21 "A Treatise on the Law of Awards," by Stewart Kyd, pp. 3, 4. 
of llon-performance. And the same emperor enacted that where the submission was accompanied by an oath to stand to the award, or the arbitrator, by the consent of the parties, bound himself by an oath to end the dispute with all regard to truth, both parties should be absolutely bound." 18 In Ireland, Bentwitch tells us, forty of the most eminent merehants in Dublin conducted a tribunal which flourished for nearly two eenturies, called the "Ouzel Galley Arbitration Society.' All disputants were at liberty to select any arbitrators they ehose from the list of the merchants. It was founded in 1700 and "only ceased to exist within the last five years"' (that is, 1888). ${ }^{19}$ In 1785, in Edinburgh, a chamber of commerce was inaugurated. Before it had been long established, it had become generally recognized as a tribunal of eommeree for the settlement of disputes between traders. ${ }^{19}$ In France, from the time of St. Louis (1250) "registers of the persons engaged in different businesses were formed to 'expedite and conelude pleas,' and merehants had their own speeial judges in the quarters where eommereial transactions were most frequent.", 19 The "Assembly of Notables," founded in 1560 , was made up of the foremost eitizens of France and was the parent of the present Tribunal de Commeree. In 1883 it became the Tribunal de Commerce. "Side by side with this institution have grown up the Conseils de Prud'hommes, the first of which was established in 1452." Its function is to settle disputes between employers and employed and to settle strikes generally. The Tribunal de Commeree is made up not of professional judges, but of merehants, elected for a limited time by the vote of their fellows: "this eleetion being regarded as equivalent to the choice of an arbitrator for business disputes." 20 Similar tribunals have been formed in Italy and Spain.

"95 Law Times 524-525.

${ }^{19}$ Ibid., y. 525 .

"Ibid., 1. 527. 
"In Holland there appears to be at present no Court of Arbitration for ordinary trade disputes, but boards of a very special nature have been formed for settling differences arising (1) in shipping business, (2) in general average cases, (3) in salvage and collision cases." "21 In Austria-Hungary for more than a century past arbitration as a means of settlement of disputes has been recognized and encouraged and in 1868 "the right was granted to the Chambers of Commerce and Industry ... to organise permanent Courts of Arbitration for the decision of disputes arising out of commercial or industrial transactions. Although there is no law compelling disputants to apply to these courts in their disputes; still ... the vast proportion of commercial difficulties are so settled." 22

In the New York Public Library there appears an old book (1779) by Champlair entitled L'Ami de la Concorde, ou Essai, Par un Avocat au Parlement. (The Friend of Peace. An Essay by an Advocate in Parliament.) The frontispiece of the book is a very sharp and more or less cynical criticism of the process of administering justice in the courts. There appears the following:

"La Justice pésant ce droit litigieux

Demande l'Huitre, l'ouvre et l'avalle à leurs yeux,

Et par ce bel arrêt terminant la bataille, Tenés, voilà, dit elle, à chacun une Ecaille

Des sotises d'Autrui nous vivons au Palais

Messieurs l'Huitre étoit bonne, allés vivés en paix." 23

This lawyer expresses the opinion that in legal conflict he himself had never been able to secure such eomplete satisfaction in winning a law suit as he found in set-

${ }^{21}$ Ibid., p. 525 .

Ibid., p. 526.

${ }^{23}$ Justice, weighing the rights of the litigants, demands the oyster which is the subject of controversy between them, opens it before their eyes, swallows the contents, and delivers to each of the parties 
tling the controversy. "La gloire de gagner des procès ma toujours moins flatle que la douce satisfaction de les prévenir, ou de les accommoder. J'ai remarqué que de tous les moyeus que j'ai employés pour persuader à ceux qui se sont adressé à moi, de próférer la conciliation ou liarbitrage, à ce qu'on appelle les voies de la Justice." 24 In the first part of the book he presents in extenso the difficulties of securing justice in the courts, and in the second part points out how much more effectively, in many cases, justice may be secured by arbitration. Another writer, A. Charmolu, treats of La Justice Gratuite et Rapide par l'Arbitrage Amiable (Speedy and Inexpensive Justice by Peaceful Arbitration). This writer reviews the history of arbitration in organized society from the earliest times and concludes that it is an old and well-tricd institution and method for obtaining justice. He traces the history of arbitration in France and points out that, as early as 1363, ordinances were passed in France, and later in 1560, 1673 and 1681, facilitating the disposition of or. dinary controversy "dans le cas de contestations entre marchands et associés commerciaux, ainsi que pour les demandes de partage et de comptes de tutelle." 25 This writer informs us that on the 13th of July in each year in the highlands of the Pyrenees, on the border line between France and Spain, the peasants come together and dispose of all the controversies that have arisen during the year, with the aid of the Alcalde of Isaba (a Spanish

an empty shell. "Mehold," she says. "For each a shell. Upon the folly of others we live in the palace. Cientlemen, the oyster was good. Depart in peace.",

2* The glory of wiming cases has always pleased me less than the quiet satisfaction of preventing them or of settling them. I have remarked that of all the methods that I have employed to persuade those who have appealed to me, conciliation or arbitration was preferable to those that one descriles as tho paths of justice.

${ }_{25}^{2}$ "L'écrivain Jean Lariverue, ch compulsant d'anciens documents, a compté jusqu'à troize invidiclioms appelies ì stalver dans una affaire qui se plaidu "n frence al fut abandonnée au bout de cent cinpuate ans. . . faute at une solution possible." 
official who acts as official arbitrator).$^{26}$ The practice in these cases is for the judge to listen to the tale of both parties and then pronounce judgment without delay and without technieality, and he points out that sinee St. Louis of France and Alphonse the Wise of Spain this practice has continued and the native peasants observe the awards made by the arbitrator with more faithfuhess than they abide by the decisious of the courts. Another French author, writing on the subjeet of arbitration (Traité Général de l'Arbitrage en Matire Civile et Commerciale by M. Goubes $u$ de la Bilennerie) reviews the very early history of arbitration in France and traces it back to its origins in Rome. He shows how simple and complete were the dispositions of eontroversy from the time of Franeis the Sec-

20 "Nous pourrions citer, comme exemple, ce fait qui se renouvelle chaque année, le 13 juillet dans le highland pyrénéen. Cc jour-là après des cérémonies qui réunisscnt lcs paysans cspagnols et les habitants français de la vallée de Barretous, l'alcade d'Isaba, tel qu'accutumaient les anciens rois de jadis, saint Louis de France ct Alphonse lc saye d'Lispagne, s'installe sur un siège formé par les racines nowcusess d'un chêne et se met à rendre la justice. Pasteurs et propriétaires de bestiaux français et espagnols arrivent en grand nombre ct exposent leurs litiges en quelques mots.

"Le juge écoute avee attention les deux parties, interroge les témoins et prononee le jugement sans délai, imposant à l'un une amende, accordant à l'autre nne indemnité, donnant à celui-ci une satisfaction, à celui-là une punition, suivant les eas.

"Ces jugements inspirent aux rudes montagnards plus de respect que les décisions de la Cour suprême, et tout lo monde s'y soumet sans murmurer."

(We could eite, as an example, the festival which is revived every year on the 13th of July in the highlands of the Pyrenees. On that day, after ceremonies which unite the Spanish peasants and the French inhabitants of the Barretous valley, the alealde of Isaba, just as did the aneient kings of former times, St. Louis of France and Alphonso the Wise of Spain, presides upon a seat formed by the knotty roots of an oak and proceeds to render justice. Freneh and Spanish farmers and herdsmen arive in great numbers and present their grievauces in a few words. The judge listens attentively to the two parties, interrogates the witnesses and pronounces judgment without delay, imposing upon one a fine, upon the other an indemnity, giving to this one satisfaction, to the other punishment, as the case may be. These julgments inspire more respect in the rude mountaineers than the decisions of the Supreme Court, and everyone submits to them without grumbling.) 
ond (1560), and how from time to time the machinery was improved upon. Another writer, F. Rigaud, in the Encyclopedie Scientifique des Aide-Hemoire, treating of " $E x$ pertises et drbitragcs," says: "L'arbitrage a une portée plus étendue: il a son origine dans la liberté fondamentale, dans le droit de compromettre sur tous intérêts, droit appartcnant cu principe à toute personne jouissant de sa liberté entiere...".

If America is to have international relations after the war, it may be of no little value to point out at this time that France, which elicits our warm admiration for its respect of liberty and law, for many centuries harbored the arbitration of mereantile disputes and treated the right to resort to arbitration as a personal right-part of the right of liberty itself.

Banister Fleteher, writing of "Arbitrations," says: "The present might, I think, with great propriety, be termed 'the Age of Arbitration.' The recommendations of the principle are such that we find it every day more generally adopted as the means of settlement of every elass of difference, from the 'burning questions' of international importanee, to the dispute as to the half-penny per hour, more or less, in the wages of the artisan." 28 This writer confesses he cannot comprehend the rule that "neither at law nor in equity could the fact that an arbitration was pending be pleaded as a bar to an aetion or suit for the same demand.", 29 Writing in his "Handbook of Average," Manley Hopkins (1884) says that since there is a elaim made upon one poliey in five, considering all of the trades, "a constant recomrse to law would be most undesirable," and consequently there is a resort to arbitration. Ile points out: "There is something quite

\footnotetext{
${ }^{27}$ Arbitration has a more extensive field; it has its origin in basic liberty, in the right to compromise all eases, a right belonging in principle to each person enjoying complete liberty.

is 2 nd Ed., 1. 1.

20 lbid., p. 4.
} 
consistent with friendly feeling in offering to leave to another's decision the opposing views which two persons entertain upon a difficult subject. And when," he says, "it is borne in mind how seldom questions arising out of the transactions we have been considering are purc and simple, or resolve themselves into the mere form of 'yes' or 'no,' but, on the other hand, how often small equitable rights are found on both sides and accessory matters are discovered, which have to be discussed pro and con, and all bring in their weight, it is not wonderful that arbitration has been a favorite resource, and has been a valuable reconciling medium between men of business." ${ }_{30}$ Thus, in the insurance world, he finds it is a matter of habit to leave matters to arbitration.

In Persia various questions of contracts, titles to land, property, even questions of disputed wills, intestate succession, the boundaries or shares of land, recoveries of debts in bankruptcy have for many centuries been submitted to arbitration. A mejilis, or informal council, is convoked in the house of a mullah or leading citizen. Both sides state their case. The documents are produced and inspected and a decision is given. It is signed and registered by the Sheikh-el-Islam or the Imam-i-Jama (the Chief Priest) and "with a little present to the jury all round, the appellants conclude what is probably one of the cheapest and most effective forms of legal procedure in the world." There is provision, however, for appeal. If either party is dissatisfied with the sentence, he may appeal to the local governor. ${ }^{31}$ In Japan, during the Tokugawa Era (seventeenth century), arbitration and compromise beeame the rule, litigation the exception. A dispute arising, parties would submit it in the first instance to the members of the "five-men group, or groups to which they belonged.

${ }^{30}$ Pp. 526-527.

"See "Persia" by Hon. George N. Curzon, M. P., 1892. Vol. I, pp. $455 \cdot 6$. 
These met in conclave, the disputants being present." To promote a friendly spirit, food and wine would be served. Rarely, if ever, did the judgment of the group fail to satisfy the disputants or at any rate to placate them. The custom goes back to the remotest times of antiquity. ${ }^{32}$ In "Miscellaneous Essays Relating to Indian Subjects," B. II. Hodgson, F. R. S., gives us an account of the system of Arbitration in the State of Nepal. "There are no permanent individual members of the Pancháyet. . . . In matters affecting persons who are neither Parbattias nor Néuárs (different tribes), there is no restriction as to the selection of the panch-men by the respective parties." 33 "Persons who sit on Pancháyets are never paid any sum, either as compensation for travelling expenses, loss of time, or on any other account whatsoever.", 33 "No man can sit on a Pancháyet without the consent of both parties." "3t "TVith the exception of cases of life destroyed, all matters may be referred to a Panchayet, at the desire of the parties . . ." ${ }_{35}$ ". . . the judge (of the Salr court) takes from the parties an obligation to abide by the award of the Panchiyet" and when given, it "is referred to the court to be carried into effect." 36 "The value of entries in merchants' books, and in general mercantile affairs, are referred by the court to a Panchayct of merchants." The Grecian law provided: "The public arbitrators ... were a body including all Athenian citizens in the sixtieth year of their age. The arbitrator, on receiving the ease from the four representatives of the Forty, first endeavored to bring the parties to an agreement. If this failed, he heard the evidence and gave a decision.

32" Japan-Its History, Arts and Literature," by Captain F. Brinkley. Vol. IV, pp. 102-4.

${ }^{x}$ Sect. XIT, Vol. II, p. 218.

"Ibid., p. 217.

3s Ibid., p. 216.

${ }^{39}$ Ibid., p. 217.

"Ibid., p. 227. 
"The Forty, who were appointed by lot, four for each of the ten tribes, acted as sole judges in petty cases where the damages claimed did not exceed ten drachmae. Claims beyoud that amount they handed over to the arbitrators ... to a publie arbitrator appointed by lot." ${ }^{38}$ Arbitration exists also in the following eountries: China, ${ }^{39}$ Belgium, the Netherlands, Germauy, Italy, Spain, Sweden and Norway, and Portngal. ${ }^{40}$

"In Seotland the words 'submission' and 'arbitration' are synonymous." ${ }_{41}$ And it has always been held in Scotland that a submission implies a contract and that, therefore, it is irrevocable except hy consent of all of the parties thereto." Billing, an English writer, treating of the subject of the "Law of Awards" (1846), says: "Arbitration when resorted to on proper occasions . . . is of inestimable value," quoting Denman, C. J., in Scott v. Van Sandeau, 1 Q. B. 109a, 1 Adolphus \& Ellis Reports (N. S.) 456, and from Mr. Justice Coleridge. ${ }^{43}$ In Scotland an agreement to refer future disputes is good even though the disputes or

${ }^{38}$ Encyclopædia Britannica, 11th Ed., Vol. XIT, p. 504.

${ }^{39}$ Ibid., Vol. VI, p. 184.

${ }^{10}$ Ibid., Vol. II, p. 327.

"11 "The Law of Arbitration in Scotland," by Woor and Macphail, p. 1. 23-24.

${ }^{42}$ Ibid., p. 1; "Law of Arbitration," by J. Parker (1845), pp.

${ }^{43} 3$ Bl. Com., p. 17, note 14, by Coleridge, J. "Excellent as trial by jury undoubtedly is as a means of investigating the truth, yet there are cases to which, for rarious reasons, it is not applicable. Thus when long and complicated accounts are to be examined, it can hardly be expected that twelve men placed at hazard in the jury-box should be able to determine very accurately upon the allowance of particular items, or to strike a nice balance between the contonding demands. Again, it will often happen that two persons lay claim to the whole of the same thing as a matter of mere right, which, under proper regulations, might very well suffice for both, and of which it might be ruinous to either to be wholly deprived, as a stream of water, yet in such case the verdict of the jury can only determine to whom the right belongs, it eannot look to the consequences nor make a beneficial division of the use between botl. In this way (arbitration) the parties have the benefit of a more deliberate investigation; if the matter be of a scientific nature, or removed from the common information of men, they may 
differences which are to form the subject of the referenee are future or contingent. ${ }^{44}$ Norse, writing "On Arbitration and Award," says: "The tendeney among business men to avoid the public tribunals and to settle their disputes by arbitration before individuals of their own choosing is growing stronger year by year. Not unnaturally they feel that they can obtain a more intelligent and satisfactory, as well as a more prompt, determination from eminent lawyers or merchants whom they select, and in whom they feel confidence, than they ean venture to expect from an average jury." 45

select some one to decide it whose habits have made him conversant with it, and by investing him with more or less power, they may have a decision more single and unbending than that of the law, prospective in its operations, and limiting in detail the future exercise of disputed rights." (This note cannot be found in the American editions, but is given as quoted by Billing, p. 16 and 17.)

" Irons and Melville: "Law of Arbitration" in Scotland," p. 58, eiting McCaul v. Monkland Railway Co., 9 Sessions Cases, Ist Series 522 .

${ }^{45}$ Preface, p. iii. 


\section{CHAPTER IV}

THE JUDICIAL RULE OF STARE DECISIS

C.inarLes Mickinn once said: "The law is a sort of hocus-pocus science, that siniles in yer face while it picks yer pocket; and the glorious uncertainty of it is of mair use to the professors than the justice of it." In his preface to "The Compleat Arbitrator: or the Law of Awards" (1770), Matthew Bacon wrote, "It is one of the greatest Objections to our Laws, that the Way to the Knowledge of them is so dark and rugged, so full of Windings and Turnings, that the most Knowing very often find it diffienlt to be able to prononnce with Certainty, concerning some Points they are sollieitous about." The uncertainty in the law, as well as its expense, is the merehant's dread. He wants to have his lawyer tell him the law of the case with exactitude and definitiveness. To do so, his lawyer reads the reports of the courts' decisions. If there are conflicting, uncertain, unstable decisions, how can he give his client exact or definite information upon the state of the law? The law of the merchant must be "staple"-as the old English statutes put it. This is the raison d'ctre of the rule of stare decisis, or, literally, "to stand upon decisions." But it has been argued by good lawyers that this duty to stand upon decisions requires repetition of error, that reiteration of error makes truth. Such sophistry brings ridicule and contempt upon the law.

The modern tendency is for courts to correct judicial error. In a reeent article entitled "Judicial Correction of Judicial Errors," Everett V. Abbot says- 
"Of all methods of eorrecting judicial errors, the judicial method is obviously the wisest, the most effective. and the most just. The mere fact that there has been error signifies that there has been injustice and the eourts are better fitted to cope with injustice than any other department of an organized state. Our courts should always be ready, therefore, to apply to their own errors and injustices the judicial method of correction. A frank acknowledgment that they can be, and are, on occasion, mistaken, and an open-minded reeption of lawyer-like and respeetful arguments tending to point out errors, will not in the slightest degree undermine their authority, or diminish the respect in which they are held. On the contrary, the more tolerant and approachable the court is, the greater will be the popular confidence in its decisions. In fact, the strongest bulwark which the courts ean erect against the recall and other insidious attacks upon our judicial system will be found in the recognized practice by the courts themselves of the principle that judicial errors are to be judicially corrected." 1

Lord Justice Bowen said: "There is and can be no such thing as finality about the administration of the law. It changes, it must change, it onght to change, with the broadening wants and requirements of a growing country, and with the gradual illumination of the public eonscience.", 2

"Cessante ratione legis cessat ipsa lex." (Reason is the soul of the law, and when the reason of any particular law eeases, so does the law itself.) ${ }^{3}$

Lord Tenterden said: "The rule is founded on a prin-

${ }^{2}$ Fale Law Journal, Vol. 26, No. 2, p. 104 (Dec. 1916).

2 " Progress in the Administration of . Justice during the Victorian Period"-Charles Synge Christopher, Baron Bowen. "Select Essays in Anglo-American Legal History,', Vol. I, p. 557.

${ }^{3}$ Broom's Legal Maxims (7th English Edition), p. 126. 
ciple of public policy; and where the public policy ceases to operate, the rule shall cease also." 4

Mr. Justice IIolmes, of the Supreme Court of the United States, writing of "The Common Law," says: "The very considerations which judges most rarely mention, and always with an apology, are the secret root from which the law draws all the juices of life. I mean, of course, eonsiderations of what is expedient for the community concerned. Every important principle which is developed by litigation is in faet and at bottom the result of more or less definitely understood views of public poliey; most generally, to be sure, under our practice and traditions, the unconscious result of instinetive preferences and inarticulate convictions, but none the less traceable to views of public policy in the last analysis. And as the law is administered by able and experienced men, who know too much to sacrifice good sense to a syllogism, it will be found that, when ancient rules maintain themselves in the way that has been and will be shown in this book, new reasons more fitted to the time have been found for them, and that they gradually receive a new content, and at last a new form, from the grounds to which they have been transplanted." 5 And also: "The first requirement of a sound body of law is, that it should correspond with the actual feelings and demands of the community, whether right or wrong." 6

Kent, in his "Commentaries," said: "Considering the influence of manners upon law, and the foree of opinion, which is silently and almost insensibly controlling the course of business and the practice of the courts, it is impossible that the fabric of our jurisprudence should not

- Stone v. Marsh, 6 Barnewall and Cresswell 551, at p. 564.

" Oliver Wendell Holmes, Jr., "The Common Law," p. 35-30.

Ibid., p. 41. 
exhibit deep traces of the progress of society, as well as of the footsteps of timc." ?

Mr. Justice Lurton of our United States Supreme Court, speaking of the rigor with which the rule of stare decisis is to be applied, said but recently:

"'The Circuit Court of Appeals was obviously not bound to follow its own prior decision. The rule of stare decisis, though one tending to consistency and uniformity of decision, is not inflexible. Whether it shall be followed or departed from is a question entirely within the discretion of the court, which is again ealled upon to consider a question once decided." 8

There are many instances where the highest courts in our country have reversed themselves, without reservation. The two most historical examples are the Legal Tender Cases ${ }^{9}$ and the Income Tax Cases. ${ }^{10}$

Within the past six months the United States Supreme Court refused to follow the Dick ease, decided only a few year's before (March 11, 1912). ${ }^{11}$

Shall a precedent overrule all reason? Lord Ellenborough said: "The question is, whether the plaintiff's dog incurred the penalty of death for running after a hare in another's ground? And if there be any precedent of that sort, which outrages all reason and scnse, it is of no authority to govern other cases." 12

In The Genesee Chicf v. Fitzhugh, 12 Howard 443, the United States Supreme Court held that the admiralty jurisdiction of the United States Courts extended to navigable

'Kent's "Commentaries," 14th Edition, Vol. I, p. * 479, 651.

"Hertz v. Woodman, 218 U. S. 205, at P. 212. Italies ours.

${ }^{\circ}$ Knox v. Lec, 12 Wall. 457, reversing Hepburn v. Griswold, 8 Wall. 603.3 .

"Pollock v. Farmers' Loan and Trust Co., 157 U. S. 429, reversing Springer v. United States, 102 U. S. 586, and Pacific Insur. ance Co. $v$. Soule, 7 Wall. 433.

"Motion Picture I'atents Co. v. Universal Film Mfg. Co., 243 U. S. 502 .

"Tere v. rawdor, 11 East's Reports 569, at p. 570. Italics ours. 
lakes and rivers comnecting them and was not limited to tide waters, reversing completely the Court's decision in The Steam-Boat Thomas Jefferson, 10 Wheaton 428 (1825). Chief Justice Taney in the course of his opinion writes: "It is the decision in the case of the Thomas Jefferson which mainly embarrasses the court in the present inquiry. We are sensible of the great weight to which it is entitled. But at the same time we are convinced tlat, if we follow it, we follow an erroneous decision into which the court fell, when the great importance of the question as it now presents itself could not be foreseen; and the subject did not therefore receive that deliberate consideration which at this time would have been given to it by the eminent men who presided here when that case was decided. For the decision was made in 1825, when the commerce on the rivers of the west and on the lakes was in its infancy, and of little importance, and but little regarded compared with that of the present day.'"13

In a recent case in the New York Court of Appeals, the Court upheld the constitutionality of the Bulk Sales Law, ${ }^{14}$ unequivocally reversing its previous decision in Wright $v$. Hart. ${ }^{15}$ In the course of an opinion, with which his colleagues unanimously concurred, Judge Cardozo said: "We think it is our duty to hold that the deeision in Wright $v$. Hart is wrong." 18 Shortly prior to this decision, the Court of Appeals wrote: ${ }^{17}$

"Lastly, it is urged that whatever might be our original views concerning this statute, our decision in People $v$. Williams (189 N. Y. 131) is an adjudication which ought to bind us to the conclusion that it is unconstitutional. While it may be that this argument is not without

${ }^{13} \mathrm{P} .456 . \quad$ Italies ours.

${ }^{14}$ L. 1909 , ch. $45, \S 44$, as amended by L. 1914, ch. 507.

${ }^{13} 182$ N. Y. 330.

${ }^{10}$ Klein v. Maravelas, 219 N. Y. 383.

${ }^{17}$ People v. Charles Schweinler Press, 214 N. Y. 395, at p. 410 and 412. Italics ours. 
an apparent and superfieial foundation and ought to be fairly met, I think that a full consideration of the Williams case and of the present one will show that they may be really and substantially differentiated and that we should not be and are not committed by what was said and decided in the former to the view that the legislature had no power to adopt the present statute.

"The statute under consideration in the Williams case, like the present one, prohibited night work by women in factories, and while its provisions were somewhat more drastic than those of the present one, it may be conceded that these differences were of details and would not serve to distinguish that statute from the present one in respect of its constitutionality. But the faets on which the former statute might rest as a health regulation and the arguments made to us in behalf of its constitutionality were far different than those in the present case. ... "So, as it seems to me, in view of the incomplete manner in which the important question underlying this statute-the danger to women of night work in faetories -was presented to us in the Williams case, we ought not to regard its decision as any bar to a consideration of the present statute in the light of all the facts and arguments now presented to us and many of which are in addition to those formerly presented, not only as a matter of mere presentation, but because they have been developed by study and investigation during the years which have intervened since the Williams decision was made. There is no reason why we should be reluctant to give effect to new and additional knowledge upon such a subject as this even if it did learl us to take a different view of such a vastly important question as that of public health or disease than formerly prevailed."

Judge Sewell, writing the opinion for the Appellate Division of the Supreme Court for the Third Department of New York State in Trombley of Carrier Co. v. Selig- 
$\operatorname{man}{ }^{18}$ which reversed a previous decision in the same case said that although "When a question has been once deeided the same parties eannot be permitted to reopen the discussion without great detriment to the public interest, and destroying that respect for the decisions of courts which it is important should be maintained," nevertheless, "There is no iron rule which precludes a court from correeting a manifest error in its former judgment or which requires it to adhere to an erroneous view of the facts or the law" and though the Court says: "the cases in which this will be done are exceptional and the power should be sparingly exercised," it holds that "It may for cogent reasons, reverse or qualify a prior decision, even in the same case." 19

Judge Page, speaking for the Appellate Division of the First Department in Kharas v. Collier, Inc. ${ }^{20}$ reverses the decision in Eichner $v$. Bowery Bank ${ }^{21}$ and says that the old rule that a eorporation was not liable for slander was "based upon the archaic doctrine that a corporation was an artificial being, invisible, intangible, and existing only in the contemplation of the law" and since "This doctrine has long since been repudiated by the courts" the former decision (Eichner $v$. Bowery Bank) "holding the contrary should be overruled." 22

As this manuscript is going to the printer, the United States Supreme Court admonishes the Bar "that the dead hand of the common-law rule of 1789 should no longer be applied to such cases as we have here," and that the question then before it must be examined "in the light of general authority and of sound reason." 23

${ }^{38} 133$ App. Div. 525.

${ }^{20}$ Italics ours.

${ }^{20} 171$ App. Div. 388.

2124 App. Div. 63.

2 Italies ours.

${ }^{23}$ See Rosen v. United States, Pakas v. United States. (United States Supreme Court Advance Opinions, Feb. 1, 1918, No. 5.) In 


\section{In Gould r. The IIudson River Railroad Co., 6 N. Y.} 522 (1852), the Court of Appeals held that the owner of lands adjoining a navigable river, in which the tide

this case, the Court holds that a previous conviction of forgery does not disqualify the person convicted from testifying on behalf of the Government in a criminal trial in a Federal court. In United States v. Feid (12 How. 361, 13 L. ed. 1023), decided in 1851, it had been heid by the United States Supreme Court that the incompeteney of witnesses in eriminal trials in the Federal courts must be determined by the rules of evidence which were in force in the respective States when the Judiciary Act of 1789 was passed, and in the Rosen and Pakas cases it was argued that, as it appeared by the common law as adninistered in New York that a person found guilty of forgery and sentenced was thereby rendered incompetent as a witness until pardoned, the testimony of Broder, a witness in the case who had in fact been found guilty of forgery in the State court, was improperly receivel. The Conrt finds that the decision in United States $v$. Reid hat never been specifically overruled, though its authority "must be regarder as seriously shaken by the decisions in Logan v. United States, 144 U. S. 263-301, 36 L. ed. 429.442, 12 Sup. Ct. Rep. 617, and in Benson v. United States, 146 U. S. 325,36 L. erl. 991,13 Sup. Ct. Rep. 60.', 'The Court says: "In the almost twenty years which have elapsed since the decision of the Benson Case, the disposition of courts and of legislative bodies to remove disabilities from witnesses has continued, as that decision shows it had been going forward before, under dominance of the conviction of our time that the truth is more likely to be arrived at by hearing the testimony of all persons of competent understanding wo may seem to have knowledge of the facts involved in a case, leaving the credit and weight of such testimony to be determined by the jury or by the court, rather than by rejecting witnesses as in. competent; with the result that this principle has come to be widely, almost universally, accepted in this country and in Great Britain.

"Since the decision in the Benson Case we have significant evidence of the trend of congressional opinion upon this subject in the removal of the disability of witnesses convicter of perjury (Rev. Stat. $\S 5392$, Comp. Stat. $1916, \S 10,295$ ) by the enactment of the Federal Criminal Code in 1909 [35 Stat. at L. 1088, chap. 321, Comp. Stat. $1916, \S 10,165]$ with this provision omitted and $\$ 5392$ repealed. This is significant, because the disability to testify, of persons con. victed of perjury, survived in some jurisdictions much Ionger than many of the other common-law disabilities, for the reason that the offense concerns directly the giving of testimony in a court of justice, and conviction of it was accepted as showing a greater disregard for the truth than it was thought should be implied from a conviction of other crime." It is because the Court is "satisfied ... that the legislation and the very great weight of judicial authority which have developer in support of this modern rule," that it concludes "that the dead hand of the common-law rule of 1788 should no longer be applied"' and, accordingly, reverses the ruling of the lower courts. 
ebbs and flows, has no private right or property in the waters of the river, or in the shore between high and low water mark, and was therefore not entitled to compensation from a railroad company, which constructed, in pursuance of a grant from the legislature, a railroad along the shore between the high and low water mark, so as to eut off all communication between such land and the river otherwise than across such roads. In Rumsey v. N. Y.\& N. E. R. R. Co., 133 N. Y. 79 (1892) the Court of Appeals unanimously reversed itself, Judge Denis O'Brien saying, ${ }^{24}$ "It is no doubt true that even a single adjudication of this court, upon a question properly before it, is not to be questioned or disregarded except for the most cogent reasons, and then only in a case where it is plain that the judgment was the result of a mistaken view of the condition of the law applicable to the question. But the doctrine of stare decisis, like almost every other legal rule, is not without its exceptions. It does not apply to a case where it can be shown that the law has been misunderstood or misapplied, or where the former determination is evidently contrary to reason. The authorities are abundant to show that in such cases it is the duty of courts to re-examine the question. Chancellor Kent, commenting upon the rule of stare decisis, said that more than a thousand cases could then be pointed ont, in the English and American reports, which had been overruled, doubted or limited in their application. He added that 'it is probable that the records of many of the courts of this country are replete with hasty and crude decisions; and in such cases ought to be examined without fear, and revised without reluctance, rather than to have the character of our law impaired, and the beanty and harmony of the system destroyed by the perpetuity of error." "25

* At p. 85 .

${ }^{25} 1$ Kent's “Commentaries"' (13 Ed.) 477; Broom's Legal Maxims, p. 153; Gifford v. Livingston, 2 Denio 392; Morse v. Goold, 11 N. Y. 281; Judson v. Gray, id. 408. 
In Isaacs $v$. Third Avenue Railroad Co., 47 N. Y. 122 (1871), the Court of Appeals had held that a carrier was not liable for a willful assault by a conductor upon one of its passengers; but in Stewart $v$. Brooklyn and Crosstown Railroad Co., 90 N. Y. 588 (1882), the Court of Appeals reversed itself and held just the contrary. In his opinion Judge Benjamin F. Tracy said: ${ }^{26}$

"To sustain the judgment in this case the counscl for the appellant cites and relies upon the case of Isaacs $v$. The Third Avenue R. R. Co. (47 N. Y. 122; 7 Am. Rep. 418). That case was discussed by counsel and determined by this court upon the assumption that the rule of the master's liability for the assault of a servant committed upon a person to whom the master owed no duty was applicable to that case. The mind of the court was not called to the fact that the rule applicable to such a case does not apply to the case of an assault committed upon a passenger by a servant intrusted with the execution of a contract of a common carrier.",

In Meeker $v$. Wright, 76 N. Y. 262 (1879), the Court of Appeals held that upon a conveyance to husband and wife they held as tenants in common and not as tenants by the entirety; and in Bertles $v$. Nunan, 92 N. Y. 152 (1883) the Court reversed the rule and held that such a conveyance created a tenaney by the entirety. The Meeker case was cited to the Court, and in referring to it Judge Robert Farl in his opinion said: ${ }^{27}$ "In that case the lcarned judge writing the opinion reached the conclusion that the common-law rule governing conveyances to husband and wife had been abrogated by the modern legislation in this State. But that portion of the opinion was not concurred in by a majority of the judges. The views of that judge were very forcibly and ably expressed, and they have been carefully reconsidered.

\footnotetext{
20 At p. 591.

${ }^{27}$ At p. 162.
} 
They do not eonvinee us that the conclusions he reached should be adopted by this court."

In Thurston v. Fritz, 91 Kansas 468, the Kansas Supreme Court reversed State $v$. Bohan, 15 Lansas 407 and all previous dceisions and held the rule that dying declarations are admissible only in criminal cases is without reasonable basis and should not longer be followed. The Court said: ${ }^{28}$

"We are confronted with a restrictive rule of evidence commendable only for its age, its respectability resting solely upon a habit of judicial recognition, formed without reason and continued without justification. The fact that the reason for a given rule perished long ago is no just excuse for refusing now to declure the rule itself abrogated, but rather the greater justification for so declaring; and if no reason ever existed, that fact furnishes additional justification."

Samuel B. Clarke, former partner of ex-Senator Root, has written trenchantly upon this subject of "How may judges, practising lawyers and teachers of law be made to see the viee of the illicit preconecption and stare decisis habits and their duty to take thought and fortify their wills for its eorrection?" In a series of pamphlets distributed among some members of the Bar and which are to be found at the library of the Assoeiation of the Bar of the City of New York, he says: "In this Nation it is illegal as well as highly immoral doctrine which says to the judges of our courts: 'Stick to your decisions whether right or wrong. Be blind to your errors. If the people do not like your decisions let them amend their constitutions and statutes.' " He points out that just as "During the Nineteenth Century physicists shook off the stare decisis habit and approached the problems of medicine and surgery and mechanics and other physical science

${ }^{28}$ At p. 475 . Italics ours. 
with unfettered minds", with such good result to mankind, it is now "time for lawyers and judges to take thought and exert their wills in order to rid themselves of the same bad habit."

Another writer, Robert Sprague IIall, in the "Illinois Law Review," for May, 1917,", on "Law and Logic: A Study in Applied Law," pleads for the stimulation of incuiry into the actual basis of reason that underlies the decisions of our courts and for "a thorough study of such cases and an application of their methods to the analysis of cases whose decisions have proved unsatisfactory to cornpetent and fair-minded lawyers," and contends that "The popular demand" of the day "is that courts should be abreast of the social and business world in which they play so important a part. In the general tendeney of our day to demand the reason of things, to go to the bottom of them, the methods of our judicial tribunals can not forever escape the searchlight of criticism." The process which he invokes is the examination of "rules of law in the light of a broader notion of human rights," from which examination "it will be found that some of the rules ought never to have been made, or lave long outlived their usefulness, while others require the limitations arising from giving effect to still other rules, as worthy as they of consideration." The judges, he says, "intelligent and enlightened men" though they be, and "ready to administer the law as justly as may be in their power," nevertheless "find their hands tied by traditions which they dare not ignore" and "need leaders, judges brave enough to disregard traditions which they are clear-headed enough to see to be obstructive to justice, and who are also capable of showing by convincing reasons that the traditions must be cast aside.",

Bartley, Ch. J., in Leavitt and Lee v. Morrow, 6 Ohio St. 71, at p. 78, says: "Precedents are to be regarded as the ${ }^{26}$ Vol. XII, No. 1, p. 14. 
great storehouse of experienes: not aluays to be follourd, but to be looked to as beacon lights in the progress of judicial investigation, which, although, at times, they may be liable to conduet us to the paths of error, yet, may be important aids in lighting our footsteps in the road to trutl.", 30

In succeeding chapters we shall trace the birth and growth of a rule in the law that has been variously described by great judges in England and in America as "inveterate error"- "an absurdity in the law" - "without reason"-_an anomaly in the law"-" an irrational state of the law." Mistakes in the law dne to conditions long since changed have been corrected. Many younger errors of the kind have long ago been corrected and consigned to the limbo of judicial curiosities. This one, hoary with three centuries of age, still survives. A recent newspaper report told of an old lady who found a needle which she had swallowed when a child. Not long ago she felt a twinge, put her hand to her shoulder, and pricked her finger upon the needle. It had been voyaging about in the old lady's system for fifty years, and now came to the surface to remind her of its presence. Her husband pulled it out with a pair of tweezers. The doctrine we are about to study is the needle in the common law of arbitration. By inadvertence, the doctrine of recocability was swallowed three hundred years ago. It has lingered in the system, and modern conditions bring it to the surface to prick our fingers. It could be extracted with little pain, with no harm to the body of the common law, and with a tonic effect upon business. It has lingered only by reason of the doctrine of store decisis.

The late $\mathrm{Mr}$. Charles F. Southmayd, in arguing before our Court of Appeals in $1872,{ }^{31}$ said that "if at any time within the last fifty years (1822-1872) the question would

${ }^{30}$ Italics ours.

${ }^{81}$ See post, p. 232. 
have been presented as a new one to the courts, no such doctrine would have been established." Even then it was, as he said, "upheld purely on the principle of stare decisis."

Only recently Judge IIough, now a member of the Federal Circuit Court of Appeals for the Second District, found it difficult to accept the doctrine, so examined into it with some care. He, like Mr. Southmayd, could find nothing save stare decisis to support it. But as it had been approved by the United States Supreme Court, it could be changed, so he said, only by that Conrt's action. The rule, said he, "must be obeyed . . . even though inferior courts fail to find convincing reasons for it."

The rule lacks all support in reason, especially in the light of present-day facts; what if it lack support in authority-if the courts err in belicving that they correctly stand upon precedent? Suppose lawyer after lawyer and judge after judge followed what, upon eloser scrutiny, proves to be no authority; suppose in the country from which we took the "precedent" it long ago lost its binding weight and authority; shall we then decline the task of correcting this error in our law? Does repetition of error make it truth? 


\title{
PART TWO-THE DOCTRINE OF RE- VOCABILITY: A JUDICIAL ERROR
}

\author{
CHAPTER V \\ ANALYSIS OF THE ENGLISH AUTHORITIES
}

THE carliest readily obtainable book on the subject of arbitration is March on "Actions for Slander and Arbitrements," written by J. O. March, of Gray's Inn, Barrister, in 1648. In his discussion of the question" "whether the authority of arbitrators be countermandable or not," March relies upon certain Year Book cases and upon Brooke's Abridgment, which had appeared in Law French, described by Professor Maitland ${ }^{2}$ as " a debased jargon," seventy-five years earlier, under the ominous and discouraging title: La Graunde Abridgement, Collect \& escrie per le Judge tres reuerend Syr Robert Brooke Chivalier, nadgairs chiefe Justice del comon banke.

March's views will bear elose examination, for their revelation of the early attitude toward commereial arbitration: "In this case also the Law will be strong and evident, that this authority is countermandable at any time before the $A$ ward made; but not after: because then the Authority is executed, and cannot be countermanded, and so are all our Books, but 5 E. 4, where it is said, That if a man be bound to stand to the Arbitrement of J. N. he cannot discharge the Arbitrator; contrary if he were not kound to stand to his Arbitrement: yet Brook upon

'March: "Actions on Slanier and Arbitrements," p. 164.

${ }^{2}$ Introduction to the Year Books of Elward II, p. xxxiii, edited for the Selden Society by F. W. Maitland. 
this Case saith, That it is clear that he may discharge the Arbitrator in both eases; but in the one ease he shall forfeit his Bond, in the other he shall lose nothing, because c.x muda submissione non oritur actio; so likewise it is resolved in Vinyors Case, which $I$ shall put you presently. "In 28 II. 66 by Ashton, Justice, If there be two Plaintiffs, and one Defendant; or two Defendants and one Plaintiff, put themselves to the award of other's, neither the one Plaintiff without the other, nor the one Defendant without the other, may discharge the Arbitrator; the reason is obvious, because that they were chosen by the joynt authority of both, and therefore cannot be countermanded by one alone.

"But that which is the last and best authority, is Vinyors Case; where it is resolved, That though a man be bound to stand to the Arbitrement, ete., yet he may countermand the Arbitrators; the reason that is given is, because a man eannot by his own act make such an authority, power or warrant; not countermandable, whieh by the Law and its own proper nature is countermandable: as if I make a Letter of Attorney to make Livery, or to sue an Aetion in my name, or if $I$ assign Auditors to take an aecount, or if I make one my Faetor, or submit my self to an Arbitrement, though that these are done by express words irrevocable, or that I grant, or am bound that all these shall stand irrevocable, yet they may be revoked; so if I make my Testament or last Will irrevocable, yet I may revoke it.

"But in this case it was further resolved, That by the countermand or revoration of the power of the Arbitrator, the Bond (according to the Opinion of Brook before cited) is forfeited, because he was bound to stand to his award, which he doth not do when he discharges the Arbitrator. I have sufficiently eleared it, That the authority of Arbitrators is countermandable." ${ }_{3}$

"March: "Aetions on Slunder and Arbitrements," pp. 164-166. 
We shall study Vynior's Case separately. For the present let us consider March. It will be observed at the outset that nothing is said by this early writer to indicate that agreements such as we are considering are against public policy. Whether at this date judges were influenced by the consideration of the fees of their office to draw litigation to themselves (see discussion of this subject, post p. 253 et $s \in q$.), it would nevertheless appear that when March wrote (1648) they were not influenced by such considerations. On the contrary, March himself says, speaking of arbitrators and their power, "An Arbitrator is, as our Books say, a Judge, indifferently chosen by the parties, to end the matter in controversie between them, ad Arbitri$u m$, and therefore they are said to be Arbitrators, because they have an Arbitrary power, and may judge according to their will and pleasure, so that their Judgment be according to the submission; and these Judges are not tied to any formalities, or punctualities in Law, neither are they sworn, as other Judges established by publike authority are.

"Resides, their Power is far greater, for as they may" judge as they please, keeping themselves to the Submission, so their sentences are absolutely definitive and conelusive, from which there lies no Appeal; as it was excellently well said by Meath, Justice, in arguing of the Case of Rudston and Yates, cited before (Mich. 17 Car. in the King's Bench) the Judgment of Arbitrators, said he (provided that they keep themselves to their Jurisdiction) is higher than any Judgment given in any Court; for if they erre, no Writ of Error lies to reverse their Judgment, no, not so much as Equity against them." ". We find, then, that at this time the courts respected arbitration when it was actually had. Indeed, in discussing this very topie of the countermandability of the authority of

- See post, p. St et seq.

- March, p. 160-161. 
arbitrators, we find that March discourses upon the effeet of a revocation without deed and finds that where the authority is "by deed, in such case I conceive the authority caunot be countermanded but by deed and so is 49 E. 3. 9. but where it is without deed, there the authority may be countermanded without deed; and this I ground upon that Rule of Law, codem modo quo quid creatur dissolvitur. It is but agrceable to natural equity, That every thing should be dissolved by the same means or power that it was created." ${ }_{6}$ Thus we see that if he who desires to revoke, where the submission is by deed, fails to revoke by deed, the submission is good and, in consequence, the arbitrament is good. So, also, March discusses "whether there ought to be notice of the countermand, or not" " and after a discussion of all of the preceding cases he finds that "It was resolved, That without notice, it is not revocation of the authority; and therefore if there were no notice in this case (saith the Book) the Defendant ought to have taken issuc, quod non revocavit, ete., and if there were no notice, it shall be found for the Defendant."'s

It is already apparent that in March's time the courts engaged in the strict and artificial reasoning of the period, reverently drawing conclusions from assumed premises, in aceordance with the rules of logic, and acted upon these conchusions, however absurd the consequences. Now, coming to the basis for the statement that the authority of an arbitrator is countermandable, the reason given by Mareh is "because a man eannot by his own act make such an anthority, power or warrant; not countermandable, which by the Law and its own proper nature is countermandable," ${ }^{\circ}$ and he draws an analogy

- March, p. 166.

- Ibid., p. 167.

- Ibid., pp. 167 and 168.

- Ibid., p. 165. 
from the authority of a factor, or the making of a last will and testament, or a letter of attorney to make livery or to sue an action in a principal's name. Obviously, the use of the words "authorize and empower" contained in the formal deed designating the arbitrator led the judges to think of the arbitrator as an agent, for otherwise the "authority, power or warrant" would not at that time have been by "its own proper nature" countermandable. Now, it is a very curious thing that but a few pages anterior to this statement by March, in discussing the nature of an arbitrator, he says:" "But I do not find in our Law, that either legal or natural disabilities, do hinder any man from being an Arbitrator, or avoid his sentence, and certainly they do not; for this differs much from the submission to an Arbitration, for in such case, a man ties his interest, and binds his person, which every one is not of capacity to do; but in this ease what he doth, as arbitrator, is onely to charge or discharge others. And besides, they are chosen by the parties themselves, and if they be not eompetent Judges, the fault is theirs that chose them." 11 As we have seen from previous discussion, the arbitrator is in no sense to regard himself as an agent. He may be a mediator or even a judge, but he is not an agent. It is this fundamental error of reasoning to which Judge Maule later referred as "inveterate error."

In 1844, the Supreme Court of Tennessee made this point very elear. ${ }^{12}$ "It has been argued," said Judge Turley, speaking for the Court, "that the award having been reduced to writing and signed by the arbitrators, it is to be considered as a settled account signed by the parties, the arbitrators being their agents for that purpose. We do not think so. An arbitrator is not an agent; he

\footnotetext{
10 Ibid., pp. 159-160.

${ }^{13}$ Italics ours.

${ }^{12}$ Collins v. Oliver, 4 Humph. (Tenn.) 439 , at p. 440.
} 
is not acting for and in the stead of the party seleeting him, whose interest it is his bounden duty to protect, but as a person vested with power by the law to examine and determine the matters in controversy, which have been submitted to him, and whose imperative duty it is to do equal justice to the parties disputant; his duties are more of a judicial than a fidnciary eharacter, and his determination partakes more of the nature of a judgment against, than a contract on the part of the person to be charged; and therefore, where the award has been made in good faith, and in accoldance to the forms required, it is binding and conclusive upon the parties; and it has to be sued upon only, because an arbitrator is not vested with power to enforce lis decrees by exeeution, which is the end of the law."

Bell tells us ${ }^{13}$ that the submission in Scotland was not held revocable at the will of either party singly, but that it might be done only by the concurrence of the parties. His reasoning is pertinent here: "Being a mutual and onerons contract, and the object of it being to obtain a binding and final decision, which must, in the great majority of instances, oecasion much disappointment to one at least of the parties, it is difficult to understand how it should ever have been regarded in any country as contimuing revocable at the plcasure of either party up to the date of the award. This seems, on the contrary, to be ineompatible with the fair or beneficial working of the system of arbitration." Bell (who is the great Scotch authority on the law of arbitration) says: "Apparently, therefore, no men conld (under English law) even by the most express words and formal deed, make an irrevocable agreement to authorize their own seleeted arbiter to decide for them. It is impossible to aroid suspecting that such a doctrine must be rested upon some subtlety, of a char-

18 "Law of Arbitration in Scotland," 1877. 2nd Edition, pp. $28,29$. 
acter too refined for common use." 14 Or, to ruote from Lord Cranworth, Chancellor, in Drew 2. Drew, ${ }^{15}$ this feature of the English law of arbitration by which parties might revoke an agreement to arbitrate "was an inconvenient, and, I think I may be allowed to say, an irrational state of the laue... I say that was an absurd state of the law. ..."

Before proceeding further in our analysis of the text writers of the time and the early English authorities prior to Vynior's Case, it may be of value to recreate something of the environment in whieh these decisions were made, and for the purposes of so treating the matter we shall conveniently discuss it under two headings:

1. The slow emergence of legal concepts of contractual obligations.

2. The conflict between the Law Merchant and the Common Law.

${ }^{14}$ Ibid., p. 29. Italies ours.

${ }^{15} 2$ Macqueen's Cases on Appeal, pp. 3, 4 (Scotch, 1855). Italics ours. 


\section{CHAPTER VI}

\section{THF SLOW EMERGENCE OF LEGAL CONCEPTS OF CONTRACTUAL OBLIGATIONS ${ }^{1}$}

IN the early English law, before the Norman Conquest, Pollock and Maitland tell us, the law of contracts holds anything "but a conspienous place among the institutions of English law." 2 It was of the most rudimentary form. "Many centuries must pass away before it wins that dominance which we at the present day concede to it." 3 And again: "Even in the schemes of Hale and Blackstone it appear's as a mere supplement to the law of property." 4 The most fundamental rules of contract, familiar to modern lawyers and hardly requiring any explanation, "perished in the general breaking up of the Roman system, and had to be painfully reconstrueted in the middle ages." 5 The written document was slow in presenting itself as a validating form for transactions. Though, according to the Lex Romana, "anyone who contravenes or will not perform a written agreement is infamous and to be punished." "In the early English law the written document, "which few have the art to manufacture, is regarded with mystical awe; it takes its place beside the festuca . . . setting one's hand to it is a stipu-

${ }^{1}$ For most of tho statements (except as otherwise mentioned) under this point, we are indebted to Pollock and Maitland's "History of tho English Iaw," Vol. II, p. 182, and to Page on Contracts, Vol. I, Chapter I, "History of the Law of Contract."

2Pollock and Maitland, Vol. II, p. 182.

Ibid.

- Ibid.

Ibid., Vol. IT, pp. 182-183.

-Ibid., Vol. II, p. 190. 
latio; it is delivered over as a symbol along with twig and turf and glove.... it is chiefly used as a means of creating or transferring rights in land by way of gift, sale, lease or gage; it is rarcly used for the purpose of creating or attesting the creation of purely personal rights." " The Lombard merchants, familiar in Italy with carefully worded documents, found it difficult to understand why contracts so familiar under Roman law should not be enforcible under English law. At the time of Alfred's laws "writing has hardly been used for any legal purpose except when land is to be conveyed or a last will is to be made." 8 Indeed, there is no sure ground earlier than Glanvill's book, and Glanvill reminds us that in the twelfth century two new forces are beginning to play upon the law of contract. The classical Roman law is being slowly disinterred and the canon law is taking shape. "Glanvill knows a little, Bracton knows much more about both." 8 Soon in Glanvill's writing there begins to emerge, as appears from the records of the court, a special form of writ for formal written instruments, known as the writ of covenant, examples of which are given by Pollock and Maitland as of the dates of 1194 A. D. and 1201 A. D. ${ }^{9}$ It is only during the century following Glanvill that the action of covenant became formally established as a means of enforcing formal contracts. ${ }^{10}$ By the reign of Edward I. it was settled that a sealed instrument was necessary to prove a covenant. Accordingly, the action of covenant became restricted to the sealed contract, and for several centuries covenant and debt were mutually exclusive. Not until the seventeenth century could either debt or covenant be brought where a fixed and liquidated sum of money was owing under a sealed contract. ${ }^{11}$ Since at Common Law

'Ibid., Vol. II, pp. 190-191. Italics ours.

Ibid., Vol. II, p. 191.

- Page, Vol. I, p. 11.

${ }^{30}$ Pollock and Maitland, Vol. II, p. 214.

${ }^{21}$ Ibid., Vol II, p. 217. 
a contract could only be enforced by means of a writ, Common Law courts, accordingly, during the twelfth and the greater part of the thirteenth century recognized and enforced only two classes of eontracts-those under seal, and those resulting in a fixed and liquidatcd indebtedness. "For the numerous and varied contracts of other classes, no remedy was given, and under our view of what law is, we may say that no such right was recoynized by the courts of the king." 12 It was during the latter part of the twelfth and the early part of the thirteenth century that the Conmon Law eourts began to arrest the natural development of the Common Law by refusing to allow new writs to be framed for the purpose of meeting new eases as they arose. Page observes ${ }^{13}$ that this is a tendency characteristic of all legal systems of primitive type and that in a nation which is progressing in its social and economie development there is an inevitable and irrepressible confliet between legal theories and the facts of life. "A nation thoroughly alive will not remain fettered by a rigid system of law based on an obsolete theory of society." At this time began the English custom of finding relief from sueh situations through the legislature. The statute in consimili casu introduced a legal reform originating with Fing Edward I. Its adoption by Parliament was due to his initiative. It is the Statute 13 Edw. I, Chapter 24, passed in $1284 \mathrm{~A}$. D. and known as the Statute of Westminster Second because of the place wherein Parliament eonvened at the time of its passage. The name in consimili casu owes its origin to the eharaeteristie words of one of the sections of the statute. This seetion provides that "Whensoever from lienceforth it shall fortune in chaneery that in one ease a writ is found, and in like ease falling under like law and requiring like remedy is found none, the

${ }^{12}$ Page, Vol. I, pp. 12-13; Pollock and Maitland, Vol. II, pp. 209. 210.

${ }^{18}$ Page, Vol. I, p. 13. 
clerks of ehancery shall agree in making the writ; or the plaintiffs may adjourn it until the next parliament, and let the cases be written in whieh they cannot agree, and let them refer themselves (them) until the next parliament (and) by consent of men learned in the law a writ shall be made (let a writ be made) lest it might happen after that the eourt should long time fail to minister justice unto complainants." 14 All the authorities agree that this marks a turning point in the history of English law and that "If the courts had refused to extend their jurisdietion by taking advantage of this statute, equity would have so developed as to overshadow Common Law. If the eourts had promptly enforeed the statute in the spirit in which it was passed, equity would have had but a limited field for its operations. As it was, the courts compromised. Slowly, and with evident reluctance, they took a partial and limited advantage of this statute; leaving equity room to develop side by side with the Common Law." ${ }^{15}$ The development of assumpsit is very interesting. For example, as Page says, ${ }^{16}$ "To find breach of contract classed as a tort is in some respects startling." Even Blackstone elassifies a breach of contract under private wrongs as a tort. The idea that breach of contract is a kind of tort is one which did not beeome obsolete for centuries after the passage of the Statute of Westminster. An action for breach of contract, as we know it today, was unknown. In the reign of Henry IV a suit was brought against a carpenter for not building or causing to be built certain houses which he had agreed to build. The objection was made that the plaintiff was really counting on a covenant, while he failed to show a sealed contract. This objection was sustained by the court, an obiter suggestion being made that perhaps "if it had been averred

14 Ibid.

${ }^{15}$ Tbid., Vrol. I, pp. 13-14. Italies ours.

${ }^{10}$ Ibid., Tol. I, p. 14. 
that the work was begun and by negligenee left unfinished" an aetion might have lain. ${ }^{17}$ Now, Page observes that though this decision was "outwardly on a question of procedure" it was neeessarily based upon the theory "that an executory contract could not be enforced in case of mere non-performance unless under seal." And he ealls our attention to the faet that the same deeision was rendered a little later in the same reign, eiting $\mathrm{Y}$. B. 11 Hen. IV., 33, pl. 60. In the reign of Henry VI, the attempt to enforce executory contraets by the aetion of trespass was renewed. An action was brought for breach of a eontraet to build a mill, but, erime of erimes, it was not alleged that the eontraet was under seal or that the defendant had done anything thereunder. Ergo, the question presented was the same as that presented in the earlier cases. Two out of the three judges, however, were brave enough to hold that the aetion of trespass on the ease would lie. The third judge dissented on the ground that if this kind of action would lie in such a case, it would lie on every broken agreement!! And Page, it seems to us very properly, eomments that "Historieally the dissenting judge was right. The majority deeision was a departure from preeedent." 18 It was this departure which forms the leading ease on what is now regarded as a very elementary proposition-namely, that an exeeutory eontract not under seal is enforeeable. Now, if this process was a slow proeess, the next development of assumpsit in its differentiation from other forms of trespass on the ease was an equally slow proeess. At one time the courts seemed inclined to take the position that an assumpsit was not a contract at all, and even after assumpsits were regarded as eontracts there was a lingering tendency to treat the aetion as a special form of trespass on the case.

${ }^{27}$ Y. B., 2 IIen. IV., 3 b. and 4, pl. 9; Page, p. 16.

1t'age, Vol. I, p. If. 
Even Blackstone refers to "an action ou the case for what is called the assumpsit or undertaking of the defendant." ${ }_{19}$ It was only after assumpsit became an established and distinct form of action that the technicalities of actions and procedure standing in the way of enforcement by the courts of promises which the law might hold enforceable were brushed aside. The tendency of the courts to treat assumpsit as a form of trespass in the case and the fact that assumpsit finally took definite shape before there was any sound analysis of rights according to their inherent nature led to the anomalous result of extending assumpsit to many classes of cases which are not at all classed as contracts in our modern legal conceptions. "The promise in such cases was merely a legal fiction which had to be pleaded but need not be proved." 20 Without reviewing further this development, no student of the Common Law under which we live ean fail to realize that for very simple and ordinary rules of contract, accepted as commonplaces today and finding firm base in the customs of merchants and general acceptance under Roman law, it nevertheless took centuries of English judicature and parliamentary action before they became part of the great English Common Law. Indeed, says Page, "No general theory of contract was developed or attempted during the early period of the Common Law" and in the development there has been free borrowing from the Roman law; but "confusion necessarily results from imposing Modern Law with its strong tendency toward Roman principles upon a foundation of early Common Law; and from attempting to harmonize the two." 21 Indeed, says Page, "we must acknowledge that our present principles cannot be applied to the early Common Law; and on the other hand, we must also acknowledge that many of the peculiar prin-

\footnotetext{
${ }^{19}$ Ibid., Vol. I, p. 17, eiting Black. Com. III, p. 157.

${ }^{20}$ Ibid., Vol. I, p. 17 .

${ }^{21}$ Ibid., Vol. I, p. 21.
} 
ciples of the early Common Law either are obsolete or are arrested in development and that modern contract law owes part of its ideas to the gradual infusion of Roman Law and part to the original stock of the Common Law."

Holmes says: "Lord Mansfield showed his intuition of the historieal grounds of our law when he said, 'I take it that the ancient notion about the want of consideration was for the sake of evidence only; for when it is reduced into uriting, as in covenants, specialties, bonds, etc., there was no objection to the want of consideration.' 22

"If it should be objected," says IIolmes, "that the preceding argument is necessarily confined to debt, whereas the requirement of consideration applies equally to all simple contracts, the answer is, that in all probability the rule originated with debt and spread from debt to other coritracts.'" 23

"At the beginning of the reign of Henry VI it was probably still the law that the action (of debt) would not lie for a simple failure to keep a promise.' 24

The right to sue upon an implied quantum meruit was not recognized before $1609,{ }^{25}$ and the first application of this principle was to the case of the innkeeper. "It is an implied promise of every part, that is, of the part of the innkeeper, that he will preserve the goods of his guest, and of the part of the guest, that he will pay all duties and charges which he caused in the house." 2o The next beneficiary of this doctrine was the tailor and his right to recover upon a quantum meruit was recognized in $1610 .{ }^{27}$ Sheppard eites a case in 1632, which he says

20iting Pillans v. Van Mierop, 3 Burrow, 1663, 1669.

${ }^{23}$ Holmes: "The Common Law," p. 259.

"Itid., p. 282.

"Ames: "The History of Assumpsit," Vol. III, "Select Essays in Anglo-American Legal History," p. 286.

${ }^{20}$ Warbrooke v. Griffin, 2 Brownl. 254; Moore, 876, 877, s. e.

${ }^{27}$ Six Carpenters' Cuse, 8 Rep. 147 a. " But the statement that the tailor could recover in debt is contradieted hy precedent and follow- 
holds: "If one bid me do work for him, and do not promise anything for it; in that case the law implieth the promise, and I may sue for the wages.' The whole law of lien was complicated by reason of the failure to recognize the validity of a promise implied in fact. This failure to take account of an implied promise in fact, says Ames, "greatly puzzled Lord Ellenborough and his colleagues. Williams, J., is reported to have said in 1605: 'If I put my cloths to a tailor to make up, he may keep them till satisfaction for the making. But if I contract with a tailor that he shall have so much for the making of my apparel, he cannot keep them till satisfaction for the making." ", 28 Of course, as soon as the right to recover upon an implied quantum meruit was accepted, the distinction disappeared. ${ }^{29}$

While debts founded upon a specialty were all recognized as valid by Glanvill, Bracton and Britton, ${ }^{30}$ nevertheless the king's court, says Glanvill, does not enforce "privatas conventiones de rebus dandis vel accipiendis in vadium vel alias hujusmodi." ${ }^{31}$ And Bracton says likewise that the king's court will not concern itself except very rarely de gratia with "stipulationes conventionales." ${ }_{22}$ "As there are several cases in Bracton's Note Book, in which the validity of covenants affecting land are assumed to be valid, Bracton, in the passage just referred to, probably had in mind miscellaneous covenants." ${ }_{33}^{\text {"It }}$ is certainly true that the rule that any promise under seal may give rise to an action was a comparatively late deing authorities." (Ames: "The History of Assumpsit," Vol. III, "Select Essays in Anglo-American Legal Ifistory," p. 286.)

${ }^{28}$ Ames: "The History of Assumpsit," Vol. III, "Select Essays in Anglo-American Legal History," p. 289, citing 2 Roll. Ab. 92, pl. 1, 2. ${ }^{2}$ Ames: "The History of Assumpsit," Vol. III, "Select Essays in Anglo-American Legal History," p. 289.

${ }^{20}$ Ames: "The History of Parol Contracts Prior to Assumpsit," Vol. III, "Select Essays in Anglo-Anerican Legal History," p. 305.

"Glanvill, Lib, $\mathrm{X}, \mathrm{e.} 12$ and c. 18.

${ }^{32}$ Bracton, f. 100, a.

"See Pollock, "Contracts" (6th ed.), 136. 
velopment in the history of covenant. As late as the middle of the fourteenth century, Sharshull, J., said in Y. B. 21 Ed. III. 7-20: 'If he granted to you to be with you at your love-day, and afterwards would not come, perhaps you might have had a writ of eovenant against him if you had a specialty to prove your claim.' ", ${ }_{34}$ We are indebted to Professor Ames for the historical analysis of the development of the law of parol eontracts (i. e., eontracts not under seal). Of course, lawyers of the early days did not accept the doctrine that, after aceeptance, an offer conld not be withdrawn. Indeed the rule that an attempted revocation would be ignored where the offerer had promised to keep the offer open for a fixed term and had received a valuable eonsideration for the promise first found its rise in equity ; likewise the rule that attempted revocation would be ignored and a subsequent aceeptance treated exactly as if no attempted revocation had been made. The early English judges were a long time in accepting as a legal doctrine the proposition that "A person may by his acts or omission to act waive a right which he might otherwise have under the Constitution of the United States as well as under a statute." ${ }^{35}$

Nor, in the early development of the English Common Law, was there clear understanding of the nature of ageney - for example, that "An agent is one appointed to transact business and to make contracts with third persons in place of and on behalf of the person appointing him, known as the principal." ${ }_{36}$ If this understanding of the relationship of principal and agent had been in the minds of the early English judges, how could they have treated an arbitrator as an agent? In the thirteenth century the law of

"Ames: "The History of Parol Contracts Prior to Assumpsit," Vol. III, “Select Essays in Anglo-A merican Legal History," p. 305, footnote 3 .

ss Pierce v. Somerset Railway, 171 U. S. 641, at 648.

"Page, Vol. II, p. 1503. 
agency was in its infancy. ${ }^{37}$ But even in the thirteenth century men could not appear in the King's Court (except by special favor purchased from the king), by attorneys to conduct prospective litigation. The idea of representation is new, though by this time it has "spread so far that the debtor who in express written words promises to pay money either to the creditor or to the mandatory (nuntius) or attorney of the creditor is bound by his promise; he has himself given the creditor power to appoint a representative for the exaction of the debt." 38 The idea of grant of powers was also in its infancy, for while the king ever since John's day had been issuing letters of credit empowering his agents to borrow money and to promise repayment in his name ${ }^{30}$ and a great prelate would sometimes do the like, it is by this time only admitted that a man might by deed appoint another to do certain limited acts. As has been stated, he could not appoint an attorney to appear for him in court until litigation had been begun. He could appoint an attorney to deliver and receive seisin. "But of any informal ageney, of any implied agency, we read very little. We seem to see the beginning of it when an abbot is sued for the price of goods which were purchased by a monk and came to the use of the convent." 40 Nor did these Common Law judges understand that "A partial rescission of an entire contract cannot be had. The contract must be valid or void in toto." ${ }_{41}$ Nor had they reached the conelusion that there were no reasons of public policy to "prevent parties from agreeing on a means of having some fact in dispute determined by an agent of both parties as a condition precedent to litigation." 42 Nor had they yet

"Pollock and Maitland: "History of English Law," Vol. II, p. 225.

${ }^{38}$ Ibid., Vol. II, p. 224.

Io Ibid., p. 225.

* Ibid., pp. 225, 226, citing Y. B. 33-5 Edw. I., p. 567.

"Page, Vol. I, p. 221, eiting Yeomans v. Bell, 151 N. Y. 230; 45 N. E. 552 .

s' Page, Vol. I, p. 538, citing Scott v. Avery, 5 H. L. Cas. 811; 
realized that where "parties are attempting to adjust by mutual agreement the rights and liabilities arising out of a subsisting inversion of a legal right, such contract is upheld if otherwise valid." 43 (For example, that a contract not to contest the validity of a patent or to arbitrate questions of alimony and the custody and maintenanee of the children are valid.) ${ }^{44}$

We may say with Page, therefore, "that many of the peculiar prineiples of the early Common Law ... are obsolete or are arrested in development." 45

The peculiar anomaly of the revocability of agreements to submit controversy to arbitration is, indeed, in the biology of the law, an instance of arrested development. A piece of Moorish architecture set beside a Virginia colonial mansion at once arrests our eyes; but placed in its Oriental setting, its eurves appear natural and not unpleasing. It requires some re-orientation in our thinking to understand a doctrine so ineongruous to modern business as the one that a solemn promise in writing to submit a controversy to arbitration is at all times revocable.

Hamilton $v$. Ins. Co., 136 U. S. 242; President, etc., of Delaware $\$$ Hudson Canal Co. v. Pennsylvania Coal Co., 50 N. Y. 250.

${ }^{43}$ Page, Vol. I, p. 541, citing Northern Liberty Market Co. v. Kelly, 113 U. S. 199 ; Baird $v$. Baird, 145 N. Y. 659.

"4 Page, Vol. I, p. 542, citing Philadelphia, etc., Co. v. Davis, etc., Co., 77 Fed. 879 and Masterson v. Masterson, 22 Ky. L. Rep. 1193, 60 S. W. 301.

${ }^{45}$ Page, Vol. I, p. 21. 


\section{CHAPTER VII}

TIIE CONFLICT BETWEEN THE LAW MERCHANT AND THE COMMON LAW ${ }^{1}$

Lond Mansfield did not become Chief Justice of the King's Bench until 1756. Buller, J., says of Lord Mansfield that he "may be truly said to be the founder of the commercial law of this country (England)." 2 Buller also said that "Lord Mansfield employed his learning and his genius "not only in doing justice to the parties litigating before him, but in settling with preeision and upon sound principles general rules afterwards to be quoted and recognized as governing all similar cases." ", 3 Before Mansfield's time, Campbell tells us, "when questions necessarily arose respecting the buying and selling of goods, respecting the affreightment of ships, respecting marine insurances, and respecting bills of exchange and promissory notes, no one knew how they were to be determined. Not a treatise had been published upon any of these subjects, and no cases respecting them were to be found in our books of reports. . . Mercantile questions were so ignorantly treated when they came into Westminster Hall, that they were usually settled by private arbitration among the mer-

${ }^{1}$ For nearly all of the material in this chapter we are indebted to Carter: History of English Legal Institutiuns, Chapter 26, Early History of the Law Merchant; and Smith on Mercantile Law, Vol. 1, Introduction.

${ }^{2}$ Lickbarrow v. Mason, 2 T. R. 63, at p. 73.

'Carter, p. 280, citing Buller's opinion in Lickbarrow v. Mason, 2 T. R. 63. See also Lord Campbell's account of Lord Mansfield and his special jurymen-"Lives of the Chief Justices," Vol. III, pp. $304,305$. 
chants themselves." 4 And Buller, J., is authority for the statement," that before Lord Mansfield appeared, "in courts of law all the evidence in mercantile cases was thrown together; they were left generally to a jury, and they produced no established principle."

Seventeenth century law reports give the impression that there was little or no English commerce or that the people engaged in commereial pursuits rarely went to the lawcourts to settle their disputes. There are hardly any commercial eases reported in the reports of two centuries ago. There are but a few and unimportant cases on the Law of Bills of Exchange up to the time of Lord Mansfield. ${ }^{6}$ Mr. Justice Park, in his work on "Policies of Insurance," published at the beginning of the nineteenth century, says: "I am sure I rather go beyond bounds, if I assert that in all our reporters from the reign of Queen Elizabeth, to the year 1756, when Lord Mansfield became Chief Justice of the King's Bench, there are sixty eases upon matters of insuranee." ${ }^{7}$ And as to the law of Charter Parties and Bills of Lading, Sir John Davies in the seventeenth century wrote that "until he understood the difference between the Law of Merehants and the Common Law of England, he did not a little marvel what should be the eause that in the books of the Common Law of England there should be found so few cases concerning merehants and ships, but now the reason was apparent, for that the Common Law did leave these eases to be ruled by another law, the Law Merehant, which is a branch of the Law of Nations." s Says Serutton: "The reason why there were

\footnotetext{
" "Lives of the Chief Justices," Vol. III, pp. 299, 300; italice ourg.

'Lickbarrow v. Mason (1787), 2 T. R. 63, at p. 73; 1 Smith's L. C., 11 th ed., 693 .

"Chalmers: “Bills," Preface, p. 3G. Serutton: "General Survey of the History of the Law Merchant," Vol. III, "Seleet Essays in Anglo-American Legal History,' p. 7 .

Park, 8th Ed., Vol. 1, Introduction, f. lxxxix.

"Zouch: "Jurisdiction of the Admiralty" (1686), p. 89.
} 
hardly any cases dealing with commereial matters in the Reports of the Common Law Courts is that such eases were dealt with by special Courts and under a special law. That law was an old-established law and largely based on mercantile customs." 9

Malynes' book-the first published work on the Merchant Law in England-is entitled "Consuetudo vel Lex Mercatoria," i. e., The Ancient Law Merchant, and Malynes says (1622): "I have entituled the book aceording to the aneient name of Lex Mercatoria, and not Jus Mercatonum, because it is a customary law approved by the authority of all kingdoms and commonweales, and not a law established by the sovereignty of any prinee."

Blackstone said that merchants regulated their affairs "by a law of their own called the Law Merchant or Lex Mercatoria, which all nations agree in and take notice of." 10 Lord Mansfield declared that "Maritime law is not the law of a particular country, but the general law of nations." "11 In 1883, Lord Blackburn declares in the House of Lords that, with but very slight differences and peculiarities, "the general rules of the law-merchant are the same in all countries." 12

Lord Coke (to whose decisions we shall later frequently refer) became Lord Chief Justice in 1606. Scrutton finds that this date marks the "first stage" of three stages of development of the Law Merchant; "before that time you will find the Law Merchant as a special law administered by special Courts for a special class of people." ${ }_{13}$ These

- Scrutton: "General Survey of the History of the Law Merchant," Vol. III, "Select Essays in Anglo-American Legal History," p. 8.

so Blackstone: Commentaries, T, 273; IV, 67.

11 Luke v. Lyde, 2 Burr. 883, at p. 887 .

19'Lean $v$. Clydesdale Bank, L. R. 9 App. Cas. 95, at p. 105.

${ }^{23}$ Serutton: "General Survey of the History of the Law Mer. ehant," Tol. IIT, "Select Essays in Anglo-Ameriean Legal History,", p. 9 . 
were the "Courts Pepoudrous." Even in Bracton's time in the thirteenth century, it was clearly recognized that there were certain classes of people "who ought to have swift justiee, such as merchants, to whom justice is given in the Court Pepoudrous." ${ }^{14}$

"The records of these Courts," says Serutton, "are few, for obviously in Courts for rapid business law reporters were rather at a discount." 15

Lord Mansfield, it will be recalled, had a Scoteh training, and he was disinclined to favor the rigid application of the principles of the common law. Many of his decisions are traceable to the writings of jurists of other countries, wherein he found the customs of merchants all over Europe. Thus, for example in Luke v. Lyde, ${ }^{16}$ where the question of what freight was to be paid in case of goods lost at sea came up for his deeision, his rich knowledge of foreign law permitted him to refer freely to the Roman Pandects, the Consolato del Mare, the laws of Wisbury and Oleron, and various old English writcrs, as well as the French Ordonnances. In his Life of Lord Mansfield, Lord Campbell gives us a very interesting account of Lord Mansfield's method for determining commercial controversies. He says Lord Mansfield reared "a body of special jurymen at Guildhall, who were gencrally returned on all commercial canses to be tried there. He was on terms of the most familiar intercon'se with them, not only conversing freely with them in Court, but inviting them to dine with him. From them he learned the usages of trade, and in return he took great pains in explaining to them the principles of jurisprudence by which they were to be guided. Several of these gentlemen survived when I began to attend Guildhall as a student, and were

"Bracton, f. 334.

sScrutton: "General Survey of the IIistory of the Law Merchant," Vol. III, "Select Essays in Anglo-American Legal History,', [. 10.

10 Burr. 843 . 
designated and honored as 'Lord Mansfield's jurymen.' One in particular I remember, Mr. Edward Vaux, who always wore a cocked hat, and had almost as much authority as the Lord Chief Justice himself." ${ }_{17}$

Though the courts of England were far behind, the merchants had made great advances in the disposition of mercantile controversy. Even in earlier days there had been commercial tribunals for the disposition of controversy. Before the lcx mercatoria became a part of the Common Law of England, the principles of eommercial law had sceured not only a foundation in the habits and customs of merchants, but business men had developed a procedure of their own for enforcing such important instruments of commerce as contracts, bills of exchange, and insurance policies. As Smith says: "The dealings of the merehants necessitated the use of simple rules; no technical jurisprudence peculiar to any country would have been satisfactory to traders coming from many different countries. It was necessary that there should be expeditious settlements of disputes, and summary exeeutions to enforce decisions between buyers and sellers, who were strangers to each other, and who dispersed to distant places when their transactions were over. Hence arose the market law, to which reference is often made; expanded and modified, it became a principal part of lex mercatoria." 18

In 1693 Lord Stair, the great Scotch writer, wrote (at a period when commerce had made little progress in his own country) that Scotch law and custom "regard not inconsiderable damage in traffic, that it (a business contract) may be current and secure, for nothing is more prejudicial to trade than to be easily involved in pleas,

"Campbell: "Lires of the Lord Chief Justices," Vol. III, pp. 304,305 , note.

"Smith, "Mercantile Law," 11th Ed., Vol. I, Introduction, pp. Ixix, Ixx. 
which diverts merchants from their trade, and frequently mars their gain and sometimes their credit." 19

Much of the commerce of the Middle Ages was carried on at great fairs. There was little other foreign trade. In Champagne, Besancon and Lyons in France, in Antwerp in Belgium, in Winchester and Stourbridge in England, fairs were held where "gools were bought and sold; orders were given and taken there; outstanding payments were made there; and there obligations to be discharged at future fairs were contracted." 20 It is interesting in passing to observe the influence of these markets upon the development of bills of exchange. The Italian bankers invented bills of exchange because they were embarrassed by the difficulty of transporting coin and by the differences in coinage, so they became accustomed to transmitting money or settling claims at the close of the international fairs. ${ }^{21}$ Now, these markets could not be established without the permission of the king, and it became a matter of course to attach to every market a Piepoudre Court "for the purpose of swiftly deciding disputes as to contracts concluded or broken within the market.", 22 Not only in England, but in Germany, France and Italy special market courts were established. The French fairs, and more especially the foires de Champagne, acquired by royal ordinances important privileges. The maitres des foires and custodes nundinarum had jurisdietion over all the business of the fairs and thus developed what we now know as the lex mercatoria, "determined by merchants." ${ }_{23}$ The intimate relation between the transactions of merchants and mariners at this time developed the law of admiralty. The law merchant was

"See Mackenzie v. Girvan, 3 Session Cases, 2nd Series, 318, at p. 323. Italies ours. Ixix.

"20 Smith: "Nercantile Law," 11th Ed., Vol. I, Introduction, p.

Ibid., footnote D, p. lxx.

"Ivid., p. Ixx.

Ibid., p. Ixxi. 
"from the first administered in loeal and popular courts of mercatores et marinarii, and was intimately connected with the King in Council." 24 In the Statute of the Staple (27 Edward III, Statutes II, Chapter 21) there is statutory recognition of the eonnection. It is true that the Court of Admiralty, after a struggle, usurped the jurisdiction of these local and popular courts, but, in turn, the common law courts "destroyed the Admiralty jurisdiction by repeated prohibitions" and the merehants, "dissatisfied with the illiberal policy of the common lau'yers, might have resorted to the Courts of Chancery, whose doctrines and practice were very similar to their own, had not Lord Mansfield appearcd to create the mercantile law of this country." 25 These original tribunals of the merchants were lay and "not professional; they were not national, for they might be mised. The men who formed part of a market Court at Antwerp might in six months be doing the same thing at St. Ives ... and the Statute of the Staple direets not only that where two strangers are parties the inquest is to be made up of strangers, and if one stranger then a jury de medieiate, but that in every staple (the staple towns were Newcastle, Lineoln, York, Norwich, Westminster, Canterbury, Chichester, Winchester, Exeter, Bristol, Carmarthen, Devylen, Waterford, Cork and Drogheda) there shall be a mayor having knowledge of the law merchant elected by strangers as well as denizens, two 'conveniable' constables chosen by the merehants, and two merehant aliens to be associated to the mayor and constables to hear the plaints of merchant aliens." "26 Carter has discovered, as illustrating the international charaeter of these tribunals and the internationality of the law which they administered, an entry in the manorial pleas published by the Selden Soeiety (Seleet Pleas Ma-

"Carter: “History of English Legal Institutions," pp. 259-260.

${ }^{25}$ Ibid., p. 260 . Italics ours.

${ }^{20}$ Ibid., p. 264. 
norial Courts, 153) namely, "a summons to all the merchants of as many communities as there were present at the fair of St. Ives, A. D. 1275, to present themselves on the morrow coram seneschallo to consider and see that four merchants have justice and equity, inasmuch as their servant had been caught measuring canvas with a false ell and selling it." Carter tells us further that "The name Piepondre was frequently given to those Courts which were attached to fairs 'to determine the plaints of persons passing through who cannot make any stay there; such persons, that is to say, as are called pepoudrous.', 27 'These were courts of record, and if the fair was a franchise of some lord, the court was held before the lord's steward. King Edward I did his best to get the merchant speedy justice. In the ordinances which he made when he took into his hands the franchises of the City of London appears the following:

"And whereas the king doth will that no foreign merchaut shall be delayed by a long series of pleadings, the king doth command that the Warden or Sheriffs shall hear daily the pleas of such foreigmers as shall wish to make plaint ... and that speedy redress be given unto them." 28

Not only did King Edward do his best to get the merchant speedy justice, but he also invited him to regard the King in Council as the ultimate foundation of justice; so it is provided in the Statute of the Staple (27 Edw. III, Statute II) that the king's judges are not to take cognizance of things touching the staple (\$5) but this is to be the province of the lay tribunals elected by the merchants, who are to apply the law of the merchant and not the common law. The merchants are to have right done them from day to day and from hour to hour (\$19). In case of doubt, the matter goes to the Council, ${ }^{27}$ Carter: "History of English Legal Institutions," p. 266.

${ }^{28}$ Ibid., p. 270. 
or if a merchant complains of want of justice, the Chancellor and Council are to redress it without delay $(\$ 21) .^{29}$ Carter directs our attention to two celebrated cases which went to the king. The first is that of a foreigner, Simon Dederit of Guynes, who appealed to the king from the great fair at Ives on a point of mercantile law. "This was an appeal to the Dominus Rex at Westminster, 'et praedictus Simon dicit quod lex mercatoria talis est in omnibus et singulis mundinis per totum regnum. Paratus est verificare.' His opponent denies this, and the sheriffs of London, Lincoln, Winchester, and Northampton are each directed to produce before the king twelve good and lawful merchants to recognize, \&c." Carter says this case shows the carefulness of that tribunal on appeal to the Dominus Rex at Westminster. In the second case (Y. B. 13 Edw. 4, p. 9) to which Carter refers, a merchant stranger complains to the Chancellor and judges in Star Chamber. This gentleman had come into England on a safe conduct and his goods had been stolen at Southampton. The Chancellor solemnly held that such a person was entitled to sue in England "according to the law of nature in the Chancery, that is the law merchant, which is law universal throughout the world. 'Cest suit est pris par un marchant alien que est venus par safe conduit icy, et il n'est tenus de suer selonques le ley del terre a tarier le trial de xii homes et autres solempnities del ley de terre, mes doit suer icy et sera determine solonques le ley de Nature en le Chancery, viz. ley Merchant que est ley universal par toute le monde.' "' 30 In this connection, Carter observes that "One cannot help being struck with the fact that the Chancellor is here identifying the law of nations with the law of nature, just as Roman lawyers identified the ius gentium with the ideal ius naturae," and here, summarizes Carter, "lay

- Ibid., p. 271.

Ibid., pp. 271.272. 
the bond between the Chaneellor and the merehants. $\mathrm{He}$, like the practor, considered what was aequum et bonum and what was agreeable to the mores, or the usages of honest and honourable people." And Carter further observes that "One might go further and surmise that the law merchant was in fact largely based on the Roman law" and that possibly "the law merehant was the ehannel through which the Roman law chiefly affected our law." Neither the Chancellor nor the mereliant set any store on consideration or seal. The evidence is that the doetrine of consideration did not come from Chancery and that it was in spite of the efforts of Lord Mansfield that the courts of common law forced on the custom of merchants, which knew nothing of it, the purely English indigenous doctrine of consideration. ${ }^{31}$ Carter reminds us that "the civil law has very little corresponding to our doetrine of consideration; consent made the contract; it was dishonorable to break a promise once made." Very early writers of treatises on the law merehant, Malynes (1622) and Marius (1670), were not lawyers, but merchants, and Malynes regards not so much what the law may say as what merchants will say. "The credit of merehants is so delicate and tender that it must be cared for as the apple of a man's eie." 32 "The nature of a Bill of Exchange is so noble and exeelling all other dealings between merchants, that the proeedings therein are extraordinary and singular, and not subject to any prescription by law or otherwise, but merely subsisting of a reverend custom used and solemnized concerning the same (p. 261). Such is the sincerity and Candor Animi amongst merchants of all nations beyond the seas in the observation of plain dealing coneerning the said Bills Obligatory that no man dare presume to question his own

\footnotetext{
"Carter: " History of English Legal Institutions,'” p. 274, citing Pillans v. Van Mierop, 3 Burr. 1663.

P. 76 .
} 
hand." ss And Sir John Davies, writing "Coneerning Impositions" about the beginuing of the seventeenth century, says, "Whereas at Common Law no man's writing ean be pleaded against him as his act and deed unless the same be sealed and delivered, in a suit between merchants, Bills of Lading and Bills of Exehange, being but tiekets without seals, letters of advice and eredence, policies of assurance, assignations of debt, all of which are of no foree at the Common Law, are of good credit and force by the Law Merehant." 34

Now, it is a suggestive historieal fact that, notwithstanding the nature of mereantile contracts as thus treated by merehants themselves, there should have been a determination on the part of the Common Law courts to drive the mercantile courts out of existence. Take, for example, the treatment of marine insurance. ${ }^{35}$ In the middle of the fifteenth eentury, the magistrates of Barcelona devised the ordinances of insurance, and about the close of that century the practice of insuring, having been introdueed into England by the Lombards, beeame very general. Yet no reported decision in England is to be found before the reign of Elizabeth for the very obvious reason that merehants disposed of such disputes in their own courts or in some domestie forum. By the statute of 43 Eliz. e. 12, Parliament established a court or commission, consisting of the recorder, two doctors of civil law, two common lawyers and eight "grave and disereet merchants," with full power to hear and determine all assurance cases "in a brief and summary course, as to their discretion shall seem meet, without formalities of pleadings or proceedings" -in short, to administer mercantile law in the summary method peeuliar to it. Yet

${ }^{35}$ Ibid., p. 74.

${ }^{8 *}$ Carter, p. 275.

"25 Smith: 'Mercantile Law,' 11th Ed., Vol. I, Introduction, pp. lxviii-lxix. 
these courts were driven out of existence. The first and most serions blow came in the decision in the case of Came $v$. Moye. ${ }^{36}$ In this case the Court held that a judgment by the commissioners was no bar to an action at law. It will be observed that in a suit upon a policy of assurance, the commissioners dismissed the suit and the defendant pleaded that by reason of the fact that the plaintiff had been defeated before the commissioners, its judgment was a plea in bar, "as it is Intercst Reipublica ut fit Finis litium." Yet the Chief Justice and the entire Court solemnly held that this court had no jurisdiction in rem but in personam, and since "there is a certain rule that a deeree in a court of equity shall not be a bar to an action at Common Law, that, by analogy, the eommissioners being treated as a court of equity, their judgment was not a bar to a Common Law action." How strange this all sounds-that a Common Law eourt should say that a judgment of a court of equity had no binding effect upon it! This was in 1658. After this deeision there were prohibitions to restrain the commissioners, the court fell into disuse, and, writing in 1787, Park, J., said that no commission had issued in very many years.

So, too, in the history of the conflict between the Admiralty Courts and the Courts of Common Law in Coke's time. In 1575 an agreement was entered into between the Common Law judges and the Admiralty Court and brought about a temporary lull in the struggle. Another agreement was arrived at in $1633^{37}$ but by Lord Hobart's decision in Bridgman's ease ${ }^{38}$ eognizance of contracts made at sea, but not for or in respect of maritime matters, was withdrawn from the Admiralty Court. (Some time between 1614-1625.) By fictitious allegations thereafter contracts really made at sea were made at the Royal

2 Sid. 121.

si Smith, Vol. I, Introduction, p. Ixxvii.

IJob. 11. 
Exchange and so actions on charter-parties were brought within the purview of the courts of Common Law.

Holdsworth calls the opposition of Coke and the Common lawyers to the Court of Admiralty "unserupulous." "And, from the point of view of the Common Law, the attack had bcen skilfully directed upon a position which it was worth much to sccure; for the prize was nothing less than jurisdiction in all the commercial causes of a country the commerce of which was then rapidly expanding." Coke's opposition to this development meant "much inconvenience" to the merchant litigant and for the commercial law of the country "it meant a slower development." Indeed, says Holdsworth, "if Lord Mansfield is to be credited with the honorable title of the founder of the commercial law of this country, it must be allowed that Coke gave to the founder of that law his opportunity." 39

${ }^{89}$ Holdsworth: "The Law Merehant," Vol. I, "Select Essays in Anglo-American Legal History," p. 319. 


\section{CHAPTER VIII}

\section{COKE'S DICTUM IN VYNIOR'S CASE}

Tine law of New York, like that of most of the states and of the United States, may be traced directly to Vynior's Case. In Union Insurance Company v. Central Trust Company," Justice Vann says: "The earliest authority upon the subject is the celebrated Vynior's Case (4 Coke, 302), where the condition of an arbitration bond was 'to stand to, abide by and perform an award.' . . This has been followed for many years and has been made the basis of a multitude of judgments both in England and in this country."

The line backward is Aston v. George (1819), 2 B. \& Ald. 395, resting upon King $v$. Joseph (1814), 5 Taunt. 452, resting upon Milne v. Gratrix (1806), 7 East 608, derived from Tynior's Case, as we shall presently see.

Vynior's Case was decided in 1609 (Trinity Term, 7 Jae. 1). At that time the only available digests were Statham's Abridgement (1470-5), Fitzherbert's Abridgement (1577), and Brooke's Abridgement (1576), all in old French."

In writing of Anglo-Saxon law, Pollock and Maitland say: "The habit of preserving some written record of all afiairs of importance is a modern one in the north and west of Europe. But it is so prevalent and so

1 157 N. Y. 633, at p. 642 .

"We here remember that dming a long age English lamyers wrote in French and eren thought in French, and to this day most. of the techical trms of the law, more especially of the private law, are of French origin.", (Encyclopalia Britannica, 11th ed., Vol. 9, p. 601, article "English Law," by F. W. M. [i. e. F. IT. Maitland]). 
much bound up with our daily habits in modern life that we have almost forgotten how much of the world's business, even in communities by no means barbarous, has been carried on without it." And these careful students say, evidently expressing their own feelings: "And the student of early laws and institutions, although the fact is constantly thrust upon him, can hardly accept it without a sort of continuing surprise." They remind us that there is great danger "of overrating both the trustworthiness of written documents and the importance of the matters they deal with as compared with other things for which the direct authority of documents is wanting," a danger that "is a specially besetting one in the early history of English law...."'3 Again: "Onr Germanic ancestors were no great penmen, and we know that the reduction of any part of their eustomary laws to writing was in the first place due to foreign influence." ${ }_{4}$ Yet even when Tynior's Case was decided, great respect was paid to precedent and authority. Coke, in addressing the reader in an Introduction to Part VII of his reports, enumerates, among the dangers against which judges should guard: "4. Novelty; for I have ever holden all new or private interpretations, or opinions, which have no ground or warrant out of the reason or rule of our books, or former precedents, to be dangerous, and not worthy of any observation: for periculosum existimo quod bonorum rirorum non comprobatur exemplo." Yet the difficulty of determining what were to be precedents was the first reason stated by Coke for publishing his own reports. ${ }^{3}$ His opening sentence is: "Nothing is or ean be so fixed in mind, or fastened in memory, but in short time is or may be loosened out of the one, and by little and little quite lost out of the other." He points this

${ }^{8}$ History of English Law, Vol. I, p. 25.

"Ibid., p. 26.

'Coke: Reports, Part I, trans. Thomas and Fraser, 1826, pp. xxv, xxyi. 
with the observation ${ }^{B}$ that, if our profession in former times had not reported "to ages succeeding, the opinions, censures, and judgments of their Reverend Judges and Sages of the eommon laws," "certainly as their bodies in the bowels of the earth are long ago consumed, so had their grave opinions, censures, and judgments been with them long since wasted and worn away with the worm of oblivion...." And for himself he says: "I have often observed, that for want of a true and eertain Report, the Case that lath been adjudged standing upon the rack of many running Reports (especially of such as understood not the state of the question) hath been so diversely drawn out, as many times the true parts of the Case have been disordered and disjointed, and most commonly the right reason and rule of the judges utterly mistaken." With prophetic vision of the consequences of his own dictum in Vynior's Case he says: "Hereout have sprung many absurd and strange opinions, which being carried about in a eommon charm, and fathered on grave and reverend judges, many times with the multitude, and sometimes with the learned, reeeive such allowanee, as either beguile or bedazzle their coneeits and judgments." ?

It was not until 1884 that Prof. Vinogradoff discovered

- Coke: Reports, Part I, trans. Thomas and Fraser, 1826, p. xxvi.

In his Introduction to Part VIII, Coke points out how two very serious errors had been made by the historians even of his own time, through failure to examine original sources of information. The first is "that the trial by juries of twelve men (whieh is one of the invineible arguments of the antiquity of the eommon laws, being only appropriated to them, ) was not instituted by the powerful will of a conqueror, as some of them peremptorily affirm they were"'; and second, "that the Court of Coinmon Pleas was not erected after the statute of Magna Charta (which was inade in tho ninth year of King Hen. 3) eontrary to that which others do hold." As to the first, he says, "there is nothing more untrue, for it is most certain and apparent by the laws of King Ethellred that it (trial by jury) was in use many years before'; and similarly, he traces the error coneerning the history of the Court of Common Pleas. Sec post, p. 135 et seq. 
in the British Museum the manuseript of Bracton's Note Book, and not until 1887 that Maitland published the first edition of it in Latin. The first English translation of either Statham, Brooke or Fitzherbert was publishcd in 1915 by the Boston Book Company, a translation of Statham's Abridgment by Margaret Center Klingelsmith. It is only within the past decade that the Year Books have been partially translated into English by the Ames Foundation and the Selden Soeicty. Yet even within these limits of modern research we may be able now to fix and determine the true place of Vynior's Case, and its suceessors in the Common Law.

First of all, let us study with a little care the case itself. It was decided in 1609 . It appears in thrce different reports, in the original Year Book as 7 Jae. 1, rot. 2629 ; twice in Brownlow and Goldesborough's Reports (2nd Ed. 1654); and finally in Coke's own Reports, Part VIII, at p. 80. It is the latter volume which is most frequently eited which we shall first examine $;^{8}$ the difference in the several reports will later bear examination.

The first sentence in the report is illuminating: "Robert Vynior brought an action of debt against William Wilde, on a bond of $£ 20$." Upon examining the pleadings, we find that the bond contained the following language :

"The condition of this obligation is such, that if the above bounden William Wilde do and shall from time to time, and at all times hereafter, stand to, abide, observe, perform, fulfil, and keep, the rule, order, judgment, arbitrament, sentence, and final determination of William Rugge, Esq., arbitrator indifferently named, eleeted, and

"Coke's Reports became "The Reports", (literally) as soon as they appeared. Parts 1 to 11 were first published in French, at different times between 1602 and 1615 (Lincoln's Inn Catalogue), or 1607-1615 (Harvard Law Library). Parts 12 and 13 were not published until 1656 and 1659 (Lincoln's Inn Catalogue), long after Coke's death. The first eleven parts were reprinted in English in 1658. (Soule: "Lawyer's Reference Manual," p. 92.) 
(hosen, as well of the part and behalf of the said $W$. Wilde, as of the part and behalf of the above named Robert Vynior, to rule, order, adjudge, arbitrate, and finally determine, all matters, suits, controversies, debates, griefs, and contentions heretofore moved and stimed, or now depending between the said parties, touching or concerning the sum of two and twenty pence, heretofore taxed upon the said W. Wilde, for divers kind of parish business within the said parish of Themilthorpe; so as the said award be made and set down in writing, under the hand and seal of the said William Rugge at or before the feast of St. Michael the Arehangel next ensuing after the date of these presents, that then this present obligation to be void and of no effect, or else the same to stand, abide, remain, and be in full force, power, strength and virtue."

In short, here is a bond, under seal, with conditions endorsed thereon, the purpose of which is to insure the observance by William Wilde of an award to be made by William Rugge, arbitrator. Robert Vynior held this bond and upon it he sought to hold Wilde. He succeeded -the last sentence of the decision is: "And afterwards judgment uas given for the plaintiff."

At this period in our Common Law one concept at least had become firmly fixed, namely, that a bond solemnly given under seal must be enforced, unless the obligor were released by the happening of one or more of the conditions endorsed upon the bond. Into this doctrine of law, as early understood, entered no consideration of principles of contract law, no discussion of execnted or executory contract. The bond, by virtue of the seal, attained a sanctity all its own. Like the grant in a deed, it vested in the obligee certain rights defeasible only upon the happening of ecrtain definite contingencies. Now, if the happening of the contingeney or condition was prevented by the act of the obligor himself, the oll judges saw the 
grave injustice in not permitting the obligee to enforce the bond, for, in truth and common reason, no man should be permitted to relieve himself of an obligation by his own act. So, as early as $1482,{ }^{\circ}$ it is said, in an action in detinue on a bond: "If you make a bond to enfeoff me of the manor by deed before a feast and you make feoffment of that manor to another before the said feast, you nevertheless have forfeited the bond because you have made impossible the performance of the condition thereof." It is this very ease which furnishes the ratio decidendi of Vynior's Case. The argument in Vynior's Case, as well as the decision, establishes this fact very clearly. William, the defendant, by John Russell, his attorney, by way of defense, prays oyer of the writing, and after hearing it, he says, that "Robert ought not to have his action aforesaid against him, because he saith, that the arbitrator aforesaid, after the making of the writing, and before the aforesaid feast of St. Michael the Archangel, in the condition aforesaid above specified, did not make any award ${ }^{10}$ in writing, under the hand and seal of the same arbitrator, between him the said William and the aforesaid Robert." Ergo, argued Russell, the condition of the bond had not arisen "according to the form and effect of that condition ;" and he professed to stand ready to verify the fact on the proofs. "Ah!" said Robert, but the reason why the arbitrator did not make his award is that you, William, "after the making of the writing aforesaid, and before the aforesaid feast of St. Michael the Arehangel," did revoke "and did call back all the anthority whatsoever which the said William Wilde, by the said writing obligatory had given and eommitted to the aforesaid William Rugge, his arbitrator, and then altogether disallowed and held void, and all and whatsoever the aforesaid William Rugge, after the

- 21 Edw. IV, 54, 55.

Io Italies ours. 
delivery of the same writings of revoeation, should do to (for) him in and about the said arbitrament," ete. And this he, Robert, was willing to stand to and prove. To this replieation, William demurred, saying that he was not required "by the law of the land" to answer. Thereupon William prayed for, and obtained, judgment upon the pleadings.

Now, there are a number of technical points in the case. It is argued, that it was not pleaded that the revocation had been communieated to Rugge, the arbitrator. But the court disposed of this upon precedent, saying that it made no difference, beeause the words "revocavit et abrogavit omnem authoritatem, of." implied notice in themselves "for without notice it is no revocation or abrogation of the authority." Consequently, on the plea non revocavit the defendant could have his day in court. Then there is mueh diseussion over the form of the bond, whether or not it is in legal effeet the same as one in 5 Edw. IV. $3 \mathrm{~b}$, where the Court said the obligor "cannot discharge the arbitrament, but that he shall forfeit his bond." But the fine spun reasoning of Coke over the meaning of "stand to" and "abide by" is swept asme 215 years later by Abbott, C. J. (1825)." "The distinetion drawn be-

${ }^{11}$ Tarburton v. Storr. Barnewall \& Cresswell's Reports, Vol. IV, p. 103. This case was an action in debt upon an agreement which provided that the plaintiff having commeneed an action against the defendant, they " "did agree with and to each other, that they the said plaintiff and defendant respectively should and would well and truly observe, perform, and keep the award, order, arbitrament, and final determination of $C . S$. ', concerning the said action, to be made within a errtain time. 'And each of the said parties did thereliy bind hinself and his executors, \&c., unto the other of them his executors, \&c., in the penal sum of $100 \mathrm{f}$ for the true and faithful observane and jerformance, on their respective parts, of the award and determination which should be made as aforesaid.' ', The defendant revokel the arbitration before the time of the award. Camplorll, in support of the demurrer raised in behalf of the defendant, argued: "Where an arbitration bond is given containing in the usual form a condition that the partieg shall 'stand to and abide' the award; it has been held that the condition is broken by a revocation of the sulmmission, but that if tho words are merely 
tween the different words above eited," said Abbott, "is, I must confess, extremely nice and subtle, nor can I discover any real and substantial difference between them." He holds in this ease that it is "a well known and established rule of law, that if a party eovenants to do a eertain thing, and afterwards, by his own act, disables himself from performing it, that is in itself a breach of the covenant. This rule," he says, "is so well established tlat authorities need not be cited in support of it." Aceordingly, he finds that "the second reason in Vynior's case is elearly applicable to the present, viz. that as the obligor had by his own act made the eondition of the bond impossible to be performed, the bond had become single." We see here how the rule eame to be applied to contracts as well as to bonds. Says Abbott, "Apply that to a eovenant, and it falls precisely within the rule which I have before mentioned. So here, the defendant having agreed under a penalty to perform an award, and having, by a revocation of the submission, disabled himself from doing so, he has broken his agreement, and thereby subjected himself to an action for the penalty."

Thus Coke's subtle reasoning as to the form of the bond is disposed of and so far as this ease is eoncerned, his admonition to the lawyers to stick to the old forms is entirely unnecessary. "This form," he says, "was invented by prudent antiquity, and it is good to follow, in such cases, the ancient forms and precedents, which are full of knowledge and wisdom." It is this reverenee for old forms and precedents and the technieal pleading of those days that will aid us to understand the nature of the error in the evolution of this branch of the law.

'observe, perform, fulfill, and keep' the award, there the condition is not broken unless an award is made and not performed," for which he cites Vyuior's Case-an error of very serious consequence, for any careful reading of the Vynior Case would have shown that the bond in the Vynior Case did contain these words, "stand to, abide, observe," etc. 
Vynior recovered upon his bond. Wilde had precluded the making of the award; Wilde was in the wrong; therefore, judgment goes against him. There was then no rule or public policy against enforcing penalties. So Tynior was allowed to recover the full penalty, whieh, we may assume, he had made large enough to cover him fully in case the arbitration did not take place. There is no consideration of any "ousting of the Court's jurisdiction." On the contrary, the Court takes jurisdiction and seems to think that it is carrying out a somd public policy in enforcing the bond. It quotes the decision in 5 Edw. 4. 3/b. for the proposition "that the obligor cannot discharge the arbitrament, but that he shall forfeit his bond."

It will be observed that thus far in our study of the case we have not found it necessary to consider the revocability of the submission. Now we come, however, to the words which have since brought about all the mischief. William's lawyer argued: "That although W. Wilde the defendant was bound in a bond to stand to, abide, observe, \&c., the rule, \&e. arbitrament, \&c. yet he might countermand it; for a man cannot by his act make such authority, pouer, or varrant not countermandable, which is by the law and of its own nature countermandable." 12 This argument is elearly unnecessary to the decision of the case, because, as we have seen, the court could and did dispose of it upon the proposition that when William revoked the authority of the arbitrator, he made it impossible for one of the conditions of the bond to arise and thus, as the old judges said, "the bond became single"-i.e. enforceable. But, though the statement is unnecessary to the ease, it is repeatedly cited as though it were final and settled doctrine. A man, says March, ean-

${ }^{12}$ Italies ours. 
not by his own act, "make such an authority, power, or warrant: not countermandable, which by the Law and its own proper nature is countermandable." 13

Let us consider the proposition upon its merits. Is it sound in reason or in precedent, even in the day of Coke? The argument is: "If I make a letter of attorney to make livery, or to sue an action, \&c. in my name; or if I assign auditors to take an aceount; or if I make onc my factor; or if I submit myself to an arbitrament; although these are made by express words irrevocable, or that I grant or am bound that all these shall stand irrevocably, yet they may be revoked; so if I make my testament and last will irrevocable, yet I may revoke it, for my act or my words cannot alter the judgment of the law to make that irrevocable, which is of its own nature revocable." Now, taking up the last illustration first, while it is true that I may revoke my last will and testament, yet if I have agreed with A. B. that, in consideration of her disposing of her property in one way, I will dispose of mine in another, A. B. can enforce the obligation against me and I can enforce the obligation against her-equity will enforce the mutual wills that we have made by virtue of such an agreement, in spite of a revocation by either of

${ }^{13} \mathrm{P}$. 165. As to the effect of this dictum upon later Digesters see:

Mareh-“"Actions for Slander and Arbitrements" (1648), p. 164 et seq.

John Wilson-- "Law Relative to Arbitration" (1793), p. 57. "How a Submission may be Revoked."

Matthew Bacon_"'The Compleat Arbitrator; or, The Law of Awards" (1770), Sec. III.

W. H. Watson- "Arbitration and Awards," pp. 36-44.

Stewart Kyd- "A Treatise on the Law of Awards," pp. 31 and 32.

"Cyclopedia of Law and Procedure," Vol. III, p. 610.

Toledo S. S. Co. v. Zenith Transportation Co., 184 Fed. Rep. 396, citing Morse on Arbitration, p. 437; 3 Cyc. 586, 604, and Vynior's Case, 4 Coke (Part VIII) 302.

Also post, pp. 128-141. 
us. $^{14}$ Accordingly, it is not true, at least in our day, that a last will and testament, "being in its nature revoeable, may never be made irrevoeable." All of the other illustrations relate to agencies, either to make livery of seizin, or to bring suit, or to take an account, or to become a factor; and lastly, per analogy, arbitrations, \&e. "or if I submit myself to an arbitrament." Here the argument breaks down.

The failure to differentiate between a power and a contract is pardonable if one keep in mind that at this stage of the evolution of the English law, there was no elear appreeiation of the nature of the mutual and reciprocal obligation of a parol contract if "the God's penny" had not passed. The old judges made a marked distinction between an obligation and a mere promise to do a thing. Kyd refers to this distinction. ${ }^{15}$ Says he: "In the year books, a distinction is taken between a submission by obligation, and a submission without obligation. In the first case it is said, that the obligor cannot discharge the arbitrator, because he is bound to stand to his award; but that in the latter it is otherwise." At this point Kyd cites in a footnote $5 \mathrm{Edw}$. IV. 3b. ${ }^{16}$ But he, like all the other writers, prefers the opinion of Lord C. J. Coke in Vynior's Case, who, he says, "explains this distinction in this way; that in both cases the authority of the arbitrator may indeed be revoked; but that where the submission is without obligation, the party revoking loses nothing; whereas, in the other case, he forfeits the penalty of his bond; for by countermanding the anthority of the arbitrators, he has not fulfilled the condition, by standing to, and abiding by their award; and beeause, when a man, by his own act, renders the condition of the bond impossible, the

${ }^{14}$ See Phillip $v$. Phillip, 160 N. Y. Supp. 624, 96 Mise. 471, an interesting opinion by .Iudge Rodenbeck. See also Rastetter $v$. Hoenninger, 214 N. Y. 66.

${ }^{15} \mathrm{Kyd}$ on Law of $A$ wards, p. 31.

${ }^{20}$ See yost, pr. 106-107. 
bond becomes single, as if no condition had been annexed" - for which he cited Vynior's Case. This reveals unmistakably the source of the doctrine of revocability.

But, says Kyd: "This difference in the effect of a revocation in the two cases, was certainly good law at the time, when it was held, that no action could be maintained on an award of a collateral thing made in eonsequenee of a parol submission; but now that it is held, that an action may be maintained on such an award, it may reasonably be supposed the courts would also sustain an action on the case for countermanding the authority of the arbitrator." 17

And may it not also be said with reason that the pendeney of an agreement or submission to arbitrate is a good plea to an action by one who breaehes the agreement or submission?

Carrying out the technical distinction of his day between an obligation and a mere promise, we find Coke saying in Vynior's Case: Where "I am bound to stand to the award which J. S. shall make, I could not discharge that arbitrament, because I am bound to stand to his award, but if it be without obligation it is otherwise ... for $e x$ nuda submissione non oritur actio."

The next error Coke falls into is in treating the delegation of power to the arbitrator as an appointment of an agent. Of course this is a false analogy, as Lord Chancellor Thurlow saw clearly. In 1790 in Calcraft $v$. Roebuck ${ }^{18}$ he said: "It is not uncommon for a person, appointed arbitrator, to consider himself as agent for the person appointing him. How that is so common I wonder; as it is against good faith" ${ }^{19}$ and earlier still, 1762, in Common Bench (Wills v. Maccarmick, 2 Wilson,

${ }_{17} \mathrm{P} .32$. Italies ours.

${ }^{18} 1$ Vesey, Jr. 221, at p. 226.

${ }^{19}$ See also Lord Lonsdale v. Littledale, 2 Vesey, Jr. 451, 452 (1794), per I. Ch. Loughborough; and Fetherstone $v$. Cooper (1803) per Lord Ch. Eldon, 9 Vesey, Jr. 67, 67 a. 
148,149 ) it is said per curiam "an award is a judgment by judges chosen by the parties themselves."

Besides, Coke was misled even as to agency, for if the agency be coupled with an interest, it is no longer "by its very nature revocable" - it has become by a man's action irrevocable. Take any of our factor agreements, running over long periods and inrolving large sums, could the principal deprive the factor of his profits, by an act of revocation? ${ }^{20}$

That Coke in his report ( 8 Co. 82) gave undue and unnecessary prominence to his dictum of the revocability of submission (wandering from the point, as Bacon might say) appears from two other reports of the same case in Brownlow and Goldesborough's Reports (Printed in 1651 ; Second Edition 1654) under "Actions of Debt."

Part 1, p. 62. Wilde versus Vinor, Trin. 7 Jac. rotulo 1629, or 2629. "Debt upon an Obligation to perform an Award. The Defendent pleads, that the Arbitrators made no Award; the Plaintiff replies, that the Defendent by writing did revoke, and null the authority of the

${ }^{20} 2$ Manning \& Granger's Reports 55. In 1840 in Taylor v. Marling a sum of money was deposited with one Fisher and he was authorized to arbitrate and settle all the differenees between the parties and pay out the money accordingly. Before his award, one of the parties was put into baukruptcy. The courts were asked to bold that bankruptey was a revocation of the submission, but they fail to find any authority for this proposition-on the contrary they hold that since Fisher was "a stakeholder" as well as an arbitrator, it was a power coupled with an interest-" "though the plaintiff did not absolutely place money (Italies the Court's) in the hands of Fisher" but instead "gave a valuable consideration for the $3500 £$ being so deposited in relinquishing his riglit to take out execution on the warrant of attorney. Each party had an interest in the fund, dependent upon the contingencies of an award being made wholly or partially in his favour." (Italies ours.)

"But, where an authority or power is coupled with an interest, or where it is given for a valuable consideration, or where it is a part of a security. there, unless there is an express stipulation, that it shall be revocable, it is, from its own nature and character, in contemplation of law, irrevocable, whether it is expressod to be so upon the face of the instrument, conferring the authority, or not." (Story on Agency, Ser. 477.) 
Arbitrators. Foster held the Bond was forfeited, although be might revoke, the Plea was, that he did discharge the Arbitrators against the form of the Condition. Siy Lord Coke held, that the porver was countermandable, if the Submission be by writing, the countermand must be by writing, if by word I may countermand by word: If two bind thenselves, one cannot countermand alone. If Obligor, or Obligee disable by their own act to make the Condition void, the Bond is single, 14. H. 7 . If $I$ am bound to infeoff $A$ and I marry her before the day, the Bond is forfeited, 18. E. 4.18.20. the great doubt was; because no express notice, but notice was implied. And the Bond forfeited, because he did not stand to it. Judgement for the Plaintiff.'

Again, as Vivion (sic) against Wilde:

Part II, p. 290. "A Man was bound in an Obligation to another with Condition to stand to, abide, and perform the award of two Arbitrators, and before award, by his writing the Obligor revoked the Authority of one of the Arbitrators: and it was agreed by all, that this Obligation is become single without Condition; and yet it was not pleaded that the Arbitrator had notice of the Revocation before the award made: And yet for that it was pleaded, that Revocavit, it was agreed that that implies notice, for without notice it is no Revocation; But it was agreed, that if a man submit himself to the award of another, and after he revokes his Authority: But before the Arbitrator had notice of that, he makes the award, the award is good and shall be performed; so if a man make a Feoffment, and Letter of Attorney to make Livery: And before Livery made he revokes the power of the Attorney: But before notice the Attorney makes Livery, this is good, but if the Feoffer makes a Lease or Feoffment to another before the Livery made by the other, this is a Countermand in Law, and shall be good without notice, for Fortior est dispositio legis quam hominis: 
But where a man makes actual Revocation of the $\mathrm{Au}$ thority, and before notice, the other executes his Authority, and in pleading the other pleads; Quod revocavit, the other party may reply, Quod non revocavit, and give in evidence that he hath no notice of that before the exeention of his Authority, and this is good, for without notice it is no revocation, where revocation is the act of the party: The Case is entred, Trinity 7. Jacobi Rotulo 2629. Vivion against Tilde."

The real decision of the case, accordingly, is upon two propositions-

(a) The liability on the bond matures if the submission is revoked;

(b) Though notiee of revocation to the arbitrator is necessary, it is implied in the pleading "He revoked," etc.

That this is the true explanation of the decision is further established by study of another case-four years later (1613) -where Coke led the court, in Common Pleas (10 Jacobi). The case is that of The Lord Mounteagle $v$. Penruddock, and is to be found in Godbolt's Reports (1613), p. 185, where "it was holden by the whole Court in this case, and agreed by all the Serjeants at the Barre, That if two men submit themselves to the arbitrament of I. S. And the Arbitrator doth award, that one of them shall pay ten pound, and the other shall make a release unto him, that the same is a void Auard, if the submission be not by Deed; ${ }^{21}$ and he to whom the Release is to be made by the Award, may have remedy for it, for otherwise the one should have the ten pound, and the other without remedy for the Release." (You could sue in assumpsit for the $£ 10$, but you could not compel the delivery of the relcase.)

"And it was resolved, That upon submission and arItalics ours. 
bitrament, that the party may have an Aetion upon the Case for not making of the Release.

"And Cook (Coke) chief Justiee said, That it was wisely done by Manwood, chiefe Baron, when he made such award, That a Lease or sueh like Collaterall thing should be done, to make his Award, that he should make the Release, or pay such a sum of money, for which the party might have a remedy. I conceive, that the reason is, That no Action upon the ease upon an Arbitrament lieth; because it is in the Nature of a Judgement. At another day, the opinion of the Court was with Cook, and 20 II. 6. and 8 E.4.5 eited to the purpose, that there ought to be reciprocall remedy." The ease in $20 \mathrm{H}$. 6 to which reference is made is reported in Y. B. 20 H.6. 18 (1412) of which there are three different abridgments (Statham, Klingelsmith trans. 12; Fitzherbert Arb. 8, aud Brooke, Arbit. 3).

A study of the case and of the three abridgments shows that each abridgment differs from the other and all three from the case itself. Nevertheless, we ean gather, by piecing them all together, that the Court deeided that an arbitrament by which the arbitrator held that both parties should exchange releases and one should in addition pay to the other 100 MI was a good plea to an action in trespass, though Newton had great diffieulty in determining how, if one party delivered the release and the other did not, the first man could eompel the delivery by the seeond. Mareh eites this ease for the proposition that "It is a good Award, that beeause that the one party hath done more trespass to the other, then the other to him, that he shall give a penny in satisfaetion, and that the other shall be quit against him." 22

The judges of those days had great diffieulty in enforeing an award where one party was required to give a release and the other was to pay money, or where the "March: "Slander and Arbitrement," p. 208. 
submission was not under seal. How could you compel the delivery of the release, or how could a thing not under seal have any enforceable value?

In Tilford $v$. French, 15 Car. Il in B. R. ${ }^{23}$ (1664), in a suit for Debt for $£ 50$, it is alleged that the plaintiff and the defendant mutually submitted to the award of J. S., who awarded that the defendant should pay the plaintiff $£ 50$ and the plaintiff on payment thereof should deliver to the defendant certain writings and also "make to him a Release." The Court held the award void, "For that the Defendant had no Remedy for the Writings and the Release upon this parol Submission"; the court did not consider the remedy of specific performance. But the reason given is: This parol submission "did not imply any Promise to perform it, and so it is an Award of one Part only." So Viner cites this case (also reported in $1 \mathrm{Keb} .635$ ) for the proposition that "mutual submission is no promise itself, but only an evidence of it."

But studying the more complete report of the case in 1 Keble 599, we find that Jones for the plaintiff argued: "This is a reciprocal promise, and therefore performance need not be averred; nor that the Submission was by Bond on promise, . . . and in such case, it need only be said that they mutually submitted." Winnington for the defendant cited Mounteagle $v$. Penruddock as "the very case in point" which "hath been adjudged for the cause, that no remedy can be had for the Release." So here, the decision is not that the award is void, as we gather from Levinz's report and Viner's abridgment of the case, but it is "resolved, no Aetion upon the Case lieth on such a Submission, the remedy being only on the Judgment of the Arbitrators. . . The Plaintiff onght to discontinue, or go to new Trial in Action upon the Case on special promise." And though by Ilyde and Curiam it is said "the Mutual Submission is no promise in it

Reported in 1 Levinz, at p. 113. 
self, but only an Evidenee of it," the real diffieulty of the Court is one of pleading, for "without express promise (alleged), no Aetion upon the Case lieth in Debt, it being long before such promise was created (meaning, we assume, the doetrine of promise implied from reciprocal obligations) which is not to be extended; and therefore it self it will not create any promise, though it be evidence of it." (Italies ours.)

The judges were in these days troubled by another point. Was an award of as high a legal nature as an "obligation" (i. e. a Deed or Instrument under seal)? So Viner says: "When a Duty accrues by the Deed in Certainty, tempore Confectionis Scripti, as by Bill, there is a certain Duty and it takes its Essence and Operation originally and only by Writing; and therefore in Debt thereupon an Award is no Plea" (eiting Co. 6. Blake 43.b). So in Morris against Creach ${ }^{25}, 22$ Car. II in B. R. (1671), where the suit is in "Debt on an Obligation by three Executors" to which the defendant pleads that the parties having submitted to arbitration of all the differences, it was awarded, "That the Defendant should be quit of the Obligation." Now, here was a pretty point: Could an obligation under seal be discharged by an award of arbitrators? Upon the plaintiffs' demurrer to the Plea, the Court held, "That an Obligation by itself is not submittable, because it is a Debt certain, otherwise it is as here, where it is submitted among other Things." Aecordingly-because the obligation was only one of the matters submitted to arbitration, "Kelynge and Twysden held the Plea good, notwithstanding the Controversies were only between one of the Plaintiffs and the Defendant ;' but Moreton, with more conscrvatisn, "doubted, not only for the said Reason, but also for that an Arbitrament is not of so high a Nature as an Obligation, and therefore ean-

2* Viner's A bridg. 103.

${ }^{25} 1$ Levinz's Rep. 292. 
not be a Bar." But, says Levinz, annotating the case: "See 45 Ed. 3.16 an Opinion, That an Award by Deed is pleadable in Bar of an Obligation. But 1 Rolle 270 is an Opinion to the contrary." And Viner cites $4 \mathrm{Hen}$. 6. 18 and 10 Hen. 7.4 in addition to Moreton for the statement that "In debt upon an Obligation, an Award is no plea."

The formality of pleading at the time is illustrated by a case in 3 Croke, 57 $7-8$, where in Trinity Term, 18 Jac. 1, 1622, a plea, that an award by arbitrator's was delivered at a place other than the one mentioned in the submission, was good, "for," as Doderidge and Houghton, J. J., say, "it is reason it should be published and ready to be delivered at the places appointed where the parties are to expect it, and not at any other place; for the parties have not by intendment any cognizance of such delivery; and there being a day and place appointed, they needed not to seek it in other places, nor to take cognizance of such delivery." ${ }_{26}$ "But Montague, Chief Justice, held, that this publication there, and the allegation that it was adtunc et ibidem ready to be delivered at the said shop in the Exchange, was sufficient."

"Coke," says Maitland, "27 "could look back to Edward III's day as to a golden age of good pleading." In Coke's day "Times of inventive liberality alternated with times of cautious and captious conservatism." 28

${ }^{20}$ This is contrary to the earlier decision in $8 \mathrm{Ed}$. IV, 10 (1469), see post, pp. 115-116. Law.",

${ }^{27}$ Encyclopæedia Britannica, 11th ed., Vol. 9, p. 603, art. "English ${ }^{28}$ Ibid. 


\section{CHAPTER IX}

THE EARLIER PRECEDFNTS CONTRA TO COKE'S DICTUM

But aecording to the earlier preeedents, was a submission or agreement to arbitrate revocable at the pleasure of either of the parties? Bracton in his Note Book eites ${ }^{1}$ three eases involving arbitration-one in 1224 , one in 1231 and one in 1233-all deeided during the reign of Henry III (1216-1272), where the awards made by arbitrators were enforeed by the courts at law upon proof of the "eonventions," or whatever doeument was given, under which the parties "put themselves upon an arbitrament." In a footnote to her translation of Statham's Abridgment of the Law, Klingelsmith says:" "That there was an early eustom for litigants, or prospeetive litigants, to agree to arbitrate the matter's in dispute between them, is shown by some very early eases. Braeton (Note Book, f. 649) has a ease of a very early date (1231), another in 1233 (732), and another in 1224 (983); all rather uninteresting eases, whieh in no way indicate that there was anything novel about the proeeeding. These eases show us nothing in regard to the procedure at that time. It was probably entirely informal, and yet it was necessary to prove the 'conventione' or whatever it was by which they 'put themselves upon an arbitrement.' In the seeond ease in Bracton (N. B. 732) (1233) one 'profert quoddam scriptum quod hoc lesiatur,' and his opponent also offered another writing which showed a later agreement, ehanging the conditions, and the latter writing was

${ }^{2}$ Bracton's "Note Book," Maitland. Folios 983,649 and 732.

${ }^{2}$ P. 123. 
apparently aecepted. The first case in Bracton (N. B. 649) (1231) shows both parties produeing their secta, which proves sufficient, but the defendant produces also 'literas petentes'; they do not secm to have any effect upon his cause, however. The third case is an entirely different proceeding (N. B. 98t) in which the final agreement sceins to be put into the hands of arbitrators, two of whom were justices sitting on the case." By reference to Bracton ${ }^{3}$ we find that the first of the three eases mentioned by Klingelsmith, the one deeided in 1231, is unusually instruetive. ${ }^{4}$ Willelmus de la Mare, or, perhaps, William of the Sea, brings a suit in which he prays that Simoni de Chelcfeuldia shall pay him damages in the amount of thirty marks for a rick of hay which had, he claimed, deteriorated. Simon pleaded that the case was one for "placitum in curia cristianitatis de catallis" (literally, a peaceful Christian court), by virtuc of an agreement entered into by both the parties to submit the con. troversy to arbitration (compromiserunt se in arbitros). The plaintiff contended that the agreement of arbitration was not adequate to eompel him to submit his differences (sectam ... non est sufficiens) and that he was entitled to his day in the King's Court. But Simon produced a second instrument, which he said had been drawn up later, and claimed that in troth, by mutual consent, Simon, as much as William, was bound to abide by the award of arbitrators and both had renouneed the privilege of the forum (set reuera de communi consensu tam ipsius Simonis quam Willelmi compromiserunt se in arbitros). Simon contended that, though the first instrument might not be valid, the secta subsequently exeented, which he produced and exhibited to the eourt, required the determination of the controversy in a "peaceful Christian tri-

"Maitland's Edition of Bracton's "Note Book" was issued only in 1887.

-Fol. 649. Vol. II of Maitland's Edition, p. 499. 
bunal" and that, if the King's Court decided the matter, both parties would be deprived of this method of determination. The concluding sentence in Bracton's "Note Book" is: "Et prohibitum est etc." Or, as we understand it, William was enjoined and prohibited from prosecuting his suit before the King's Court.

Klingelsmith also refers (Footnote 11, p. 123) to a quotation from West's Symbolography, title "Compromise and Arbitration," Pt. 2, p. 164, \$21-cvidently a very early authority, of which we have not been able to find a copy-for this proposition: "Arbitration is an extraordinary judge, which is chosen, and hath power to judge given to him by the only mutual consent ... to the end they may decide their controversies." She concludes, on the basis of the case in $49 \mathrm{Edw}$. III, which is her Note 2 to the title "Arbitrament" in Statham, that "the submission to an arbitrator could be without deed ..." and though "the early cases in the Note Book show us nothing of the process, except that it seemed to be a well established method of settling disputes between two persons," Kyd, says she, "after crediting the principles of the English law to the influence of Roman law, says that it is not 'easy to say at what precise period they were adopted here, or whether they were admitted at once, or by degrees, as a component part of our practical system. In the most ancient repositories of the decisions of our courts [the Year Books], the greater part of them are mentioned as known and uncontroverted vested law.' ", 5 Upon which Klingelsmith quotes something very modern in its tone and yet quite old in its substance: "Here (arbitration) is a tool of the law," says she "a convenient and much used tool; one which in various altered forms has come down to, and become a part of, our modern law, but we have no history of its rise, its growth, its permutations and reincarmations. It is in

'Kyd on Awards, pp. 3, 4. 
the 'most ancient repositories of our law' full-grown and attired in correct costume." " Fitzherbert's Abridgment (1577) confirms the eitations made in the footnotes of Klingelsmith's English translation of Statham (1475).

If arbitration was so early and so much a part of the "known and uneontroverted law" to be found "in the most ancient repositories of the decisions of our courts," how came it to be so arrested in its development as part of the English Common Law? The answer is elear. An analysis of the authorities diseloses that the original authority for the more modern statements of the revoeability of agreements to submit to arbitration is Coke in Vynior's Case. Mareh states as an apparently incontrovertible legal proposition the countermandability of arbitrators, and says that "The last and best authority is rinyors Case, where it is resolved, That though a man be bound to stand to the Arbitrament, \&e. yet he may countermand the Arbitrators." The reason March gives is beeause "a man eannot by his own act make sueh an authority, power or warrant; not countermandable, which by the Law and its own proper nature is countermandable ..."-reasoning almost verbatim reproduced from Vynior's Case. We have already seen that this reasoning is no part of the decision of Vynior's Case and, as we now regard legal decision, is mere obiter dicta. The other authority upon which Mareh relies is Brooke. It will be seen from the translation of Brooke, and, indeed, from March's own text, that Brooke's relianee is on $5 \mathrm{E}$. 4. "where it is said, That if a man be bound to stand to the Arbitrement of J. N. he cannot discharge the Arbitrator; contrary if he were not bound to stand to his Arbitrement: yet," says March, "Brook upon this Case saith, That it is clear that he may diseharge the Arbitrator in both cases; but in the one case he shall forfeit his Bond; in the other he shall lose nothing, because ex nuda submissione non

'Klingelsmith's Statham's "Ahridgment of the Law," p. 124. 
oritur actio...." But, when we come to examine Brooke, we find that all he actually says upon 5 E. 4 -the case to which March refers-is: "Note. Where a man is bound to abide by the arbitrament of J. N., he cannot discharge the artitrator. Contrary, if he was not bound to abide by his arbitrament tamen videt clearly that he can discharge the arbitrator in the one case and in the other (italies ours) but he shall forfeit his bond." There is nothing from which a deduction may be made such as is made by March: i. e., "he shall lose nothing, because ex nuda submissione non oritur actio," and all that there is to the report in the Year Book itself ( 5 Edw. 4.3.) is the following: "If I am bound to abide by the award which J. S. sliall render, I cannot discharge the arbitrament because $\mathrm{I}$ am bound to abide by his award, but if it is without bond it is otherwise." 7 The entire case consists of about a line and a half and we have quoted and translated all there is to it. There is no means of determining the nature of the suit, or of the defense, or whether or not there had been an arbitrament; though it may be inferred that at this time, unless a bond was given, no action would lie, because, as we have already seen, there was no such thing as an action for breach of an executory contract resting upon parol promisc. ${ }^{8}$ We get the key to the contemporary reasoning in the expression in March: "because ex nuda submissione non oritur actio." Obviously, if you gave a bond conditioned upon the happening of an event, the bond being under seal, there was a valid obligation; and if the event did not transpire your rights matured upon the bond. But if there was no bond, there was no obligation.

March does not refer to Fitzherbert's Abridgment, which, it will be recalled, was published in 1577, nor to Statham's, published about 1470. But Statham had dis-

${ }^{7}$ See ante, pp. 53-54.

${ }^{8}$ See Kyd on "The Law of Awards," p. 31. 
cussed arbitration: " 2 . If the parties put themselves into an arbitration without a deed, they can discharge the arbitrators without a deed before the day, etc., or they can put off the day by the assent of both, without a deed. But if the submission be by deed it is otherwise: by Fynehendon, in Debt, ete., for he should be discharged by both parties by deed. Reported in Y. B. Hilary, 49 Ed. III, 1. 8, pl. 14. See also Fitzh. Arbitrement 22.", In other words, Statham claimed that if an arbitrament were made by deed, the parties could only discharge the arbitrators by another deed, although they could put off the day of the arbitration by mutual consent without a deed.

Here is a vivid illustration of the effect of formality upon the legal mind. If you reduced your submission to the form of a decd of submission, or if you accompanied your agreement (to arbitrate) with a bond, you were safe and sound. Your obligor could not cancel the bond even with your assent save by another instrument of equal solemnity. You could not cancel a deed except by deed. But if you merely had a contract-a contract to submit to arbitration, and no formal, binding obligation under seal to abide by the result, you had something "ex muda." "The contracts enfored by the civil courts," says Holmes, "even as late as Menry II were few and simple.", 10

Holmes has outlined three stages in the development of the doctrine of consideration." "So far as parol contracts were concerned," the action of debt "eould only be used where the consideration was a benefit actually received by the promisor." '12 Ordinarily, an agreement to arbitrate conferred neither benefit upon the obligee nor

- Klingelsmith's “Statham," p. 117.

"Holmes: "The Common Law," p. 259.

" Ibid., p. 267 et seq.

"Ibid., p. 2il. Italics ours. 
detriment upon the obligor. It was not until much later that a promise was considered sufficient benefit or detriment to support the contract. Holmes also, as docs ${ }^{13}$ Page, refers to the curious case in Henry IV's time where it was said that if a man undertook to make repairs on another's house and by his unskillfulness spoiled his employer's timbers, an action of trespass on the case would lie. Yet the "action could not have been maintained for a simple refusal to build according to agreement; but it was suggested by the court that, if the writ had mentioned 'that the thing had been commenced and then by negligence not done, it would have been otherwise.' " ${ }^{14}$ Again, ${ }^{15}$ says Holmes: "But it cannot be denied that the allegation of an undertaking conveyed the idea of a promise, as well as that of an entering upon the business in hand. Indeed, the latter element is sufficiently conveyed, perhaps, without it. It may be asked, therefore, whether the promise did not count for something in raising a duty to act. So far as this involves the consequence that the action was in fact for the breach of a contract, the answer has been given already, and is sustained by too great a weight of authority to be doubted. To bind the defendant by a contract, an instrument under seal was essential."

Holmes gives it as the result of his study that "At the beginning of the reign of Henry VI it was probably still the law that the action would not lie for a simple failure to keep a promise." 16

Keeping in mind these intricacies in the evolution of the law, we shall now turn to the Year Book cited by Statham, where we find a case decided 235 years before Vynior's Case, not discussed by Brooke, nor by March, nor distinguished by Coke in Vynior's Case, although it

${ }^{13}$ Ante, p. 63.

${ }^{14}$ Holmes, p. 277 , eiting Y. B. 2 Hen. IV, 3, pl. 9; 11 Hen. IV, 33, pl. 60 ; Cf. 3 Hen. VI, 36 , pl. 33 .

${ }^{15}$ Ibid., p. 280 . Italies ours.

Ibid., p. 282. 
is cited, a case which is a clear and unmistakable authority contrary to the doctrine stated by Coke.

In 1375 (Hilary Term, $49 \mathrm{Edw}$. III) Brode brings an action of debt against de Ripple ${ }^{17}$ for one hundred marks on a bond. accompanied by a decd, which provided that the plaintiff and defendant should submit to the arbitration of Roger Digge and three others on a certain day at Cambridge, and in ease these arbitrators could not

"Brode $v$. de Ripple, Y. B. 49 Ed. III, 8 and 9 (1375). Debt. John, son of John Brode, brings a writ of debt against Stace de Ripple and asks for $100 \mathrm{M}$ on a bond. Hasty: He should not have an action, for we tell you that this same John who is plaintiff, by this deed indented which is here, we are bound to the aecord and arbitrament of Roger Digge, and three others, on a eertain day at Cambridge, provided they ean agrce, and if not, the arbitrament of Martin Petit, who should be eleeted mmpire in the manner aforesaid, to arbitrate eertain lands and tenements which the said $J$. Brode elaimed against the said.J. Stace in the Court of our Lord the King; that the said bond of $100 \mathrm{M}$ shall lose its force, but if they eamnot agree, as is said above, that the said John may prosecute his action in the Court of onr Lord the King, as he did before; and we say that we came to Cambridge on that very day and the arbitrators eame and could not agree; nor did anything, nor the umpire either. Therefore, there is no default in us, for which we ask judgment, if by force of the deed he ean have aetion against us or ask nothing.

Persay: Sir, you see clearly how the bond is simple in itself, and the deed whieh is put forward in defeasance of the bond holds that if he abides by the arbitrament of certain people that the deed would lose its foree and he has not allegeil that he was ready and that he is still ready to abide by their arbitrament. That, therefore, we conelude that even if they did not arbitrate on a certain date, they could arbitrate on another day, and you have never excused yourself for all time. Therefore, the bond is effeetual in toto. Wherefore we ask judgment. Aul pray for debt and our damages.

Hasty: But since the deed states in it a eertain day on which they should arbitrate and we have said that they did not agree nor arbitrate, therefore, there was no default in us and this matter (procedure) we lo not ask. We ask judgment and pray that it will be (a) bar he does not deny.

Bellinap (.Juige): If a man is bound by a deed to pay a certain sum of money on a certain day in defeasance of a bond to a great sum, if the obligce brings a writ of debt for the sum stated in the bond, I say that even if the defendant alleged that he proffered on that lay a lesser sum than stated in the deed on the day stated in the deed, if he does not allege that he was really thereafter and is still proffering the moneys at the har (i. e. keeps up the tender by tendering in court) he will not be excused of (from paying) 
agree, then to the arbitrament of Martin Petit, who was designated as umpire-a certain controversy which had arisen concerning lands and tenements to which each claimed title. The proviso of the deed was that, if the arbitrators failed to agree, or if the umpire failed to decide, then the plaintiff was to have his action at law on the bond; but if they did agree, they were both to abide by the decision of the arbitrator or umpire, that is to say, if they did abide by the award the bond would be

the sum stated in the bond, for even if he did not pay on the certain date, he is held to pay after. Therefore, \&c., when he is bound to abide to the arbitrament on a certain day, even if they did not arbitrate on that same day, it is reasonable that he is bound to their arbitrament made later: For, \&e. (sic).

Kirton (probably Roger de Kirketon, Judge of C. P., appointed $48 \mathrm{Edw}$. III): It is true in your first case of payment of moneys by the Penal Sum; but in this case the indenture wishes (sic-i. e. provides) that the party may go ahead with his action in this court on a certain day after. Therefore, if he awaits till they wish to arbitrate, he would lose his action, or the other party would lose his land. For that reason, therefore, the cases are not similar.

Persay (for the plaintiff): Therefore we tell you that Martin Petit, who was elected umpire, came to the Chancery on that very day that the four arbitrators should arbitrate and since the arbitrators could not agree, he gave a day eight days after at Ripple (i. e. adjourned the case) where the land was, by your own assent (the defendant), on which day you came there and the said Martin awarded that you should return the twelve acres of land to the said J., upon which you delivered to us seven acres as parcel. And the remainder you declined to deliver. Therefore, the award was not performed on your part. For which we ask judgment on this bond, which is (now) in force and pray for our debt and damages.

Hasty (for the defendant): But since the deed is limited that we should be bound by their arbitrament on a certain day, on which day, as we have said, they did not arbitrate, nor did anything, nor did the umpire either, therefore, we have complied with that which is stated in the indenture (deed) and also the indenture provides that if they cannot agree that he (the plaintiff) should go ahead with his action for the land on a certain day after. For that reason, as it is alleged, the umpire gave us another day besides by assent (adjourned by consent) and that we came to the land as above. No law puts us to onr answer and we pray that it be barred.

Et sic ad judicium et super hoc dies datus est usque in $\mathrm{XV}$ Paschae, ad audicndum judicium suum. And so to judgment and besides a day is giveu in 15 Easter term for hearing their judgmen'c (meaning the judges).

[I am indebted to Mr. F. de R. Storey and to Professor Joseph Warren of the Harvard Law School for the foregoing translation.] 
void. It appears from the report of the case that the original set of arbitrators was unable to agree, and therefore the matter went to the umpire, Petit. Petit, on the day fixed in the deed, was unable to arrive at a decision. In consequence, he declared an adjournment of the arbitration. Upon this footing, it is pleaded that, by reason of the failure to make the determination upon the specific day mentioned in the deed, the plaintiff was entitled to enforce the bond. It was argued, that since the umpire had not rendered any decision, therefore the arbitration had failed and the plaintiff should be permitted to recover. But Hasty, arguing for the defendant, said that since the arbitrators had been unable to arrive at a decision and had referred the matter to the umpire, and the umpire had been unable to arrive at a decision and had adjourned the arbitration, and that his client, the defendant, had appeared before the arbitrators and was ready and willing to proceed with the arbitration before the umpire on the adjourned day, it was no fault of his that the arbitration had not yet been determined, and that, in consequence, he should not be required to answer the plaintiff's suit. With this plea the Court agreed and the plaintiff was non-suited. In other words, the pendency of the arbitration and the fact that the adjourned day had not yet arrived was regarded as a good plea in bar to an action upon the bond or upon the deed. The concluding words of the decision are: "Et sic ad judicium. Et super hoc, dies datus est usque in XV Paschae, ad audiendum judicium suum." The words "Et sic ad judicium" mean "And so to judgment." (Ames Foundation: "Year Books 12 Richard II," pp. 22, 23). And the words "Et super hoc, dics datus est usque in XV Paschae, ad audiendum judicium suum" undoubtedly mean that, in addition to the judgment, a day certain was fixed for hearing and determination by the judges.

Here, then, in the reign of Edward III, is a recognition 
of the validity of the arbitration agreement, provided the parties reduce the obligation to the solemn form then recognized in the law as the necessary basis for all obligations. The instruments, a deed and a bond, were sealed; therefore the Court conld give them effect. Accordingly, the pendeney of the arbitration thereunder was treated as a bar to an action by the plaintiff, although the adjournment, as Statham observes, was not by deed.

Furthemore, Statham and Fitzherbert are authorities for the proposition: "It is a good plea that they have put themselves upon an arbitration which is not yet made; and this in Trespass" "18 and cite a case in 1389, Hilary Term, 13 Ric. II. Klingelsmith says: "There is no printed Year Book for 13 Ric. II. Fitzh. Arbitrement, 26, has nearly the same abridgment of the case." 19

With Bracton's notes discovered only in 1885, the English and American judges who have passed upon this subject have heretofore relied upon Vynior's Case as the final word upon the subject. Today we know that at least 235 years prior to Vynior's Case there was ample legal authority for the proposition that the pendency of an arbitration was a bar even to an action in trespass.

Returning once more to Vynior's Case, we find, in addition to the citation of Brooke and $5 \mathrm{Edw}$. 4., reference to 21 H.6.30a, 28, 29 H.6 6b, 49 E.3.9 a, 18 E.4.9, 8 Ed. 4.10. We shall examine each of these in turn.

Examination of the Year Book report in 21 H. VI. 30a, will not disclose whether there was any bond accompanying the submission, nor whether the submission was in writing. We find there only a plea to an action in debt that the parties had agreed to arbitrate. The action is an action upon an award, and the defendant pleads that the authority of the arbitrator had been revoked. $\mathrm{He}$ subsequently withdraws his plea and interposes the plea

${ }^{18}$ Statham, Klingelsmith's translation, p. 123.

${ }^{10}$ Ibid. 
that he is not indebted. The ease does not diselose its outcome. All that we find at the end is: "And he made his law." The eitation in rymior's Case must be based upon Brooke's digest of the ease, for Brooke says that in an action of debt, where arbitrament is pleaded, it is a good plea that, after the submission and before an award was rendered, the plaintiff discharged the arbitrator on such a day, year and place. ete., for that ean be eountermanded. But the case itself, as it is reported in the Year Book, does not support Brooke's abridgment. Fitzherbert does not refer to the ease at all.

As bearing upon the looseness of reports in the Year Books, Kyd ${ }^{20}$ states that "a ease is reported in two books, in one of which a doubt is expressed, whether all being by parol, the plaintiff eould maintain that action (on an award) or have any other remedy; but that," says Kyd, "is evidently nothing more than a loose note of the reporter, and the pleadings are there very inaceurately stated. In the other book, the ease is reported at length, and the manner of the pleadings distinetly given; the breach being assigned in a diseharge by the defendant of the arbitrators from making any award; and the judgment of the eourt, without mueh hesitation, in favor of the plaintiff." ${ }_{21}$

There remain to consider but two more references in Tynior's Case-18 E. 4, 9 and 8 Ed. 4, 10. Upon examination of $18 \mathrm{Edw}$. IV, 9 (1479), we diseover that the action was an aetion on covenant brought upon an indenture, by which the defendant agreed to pay the plaintiff $£ 10$ upon eondition that the plaintiff build a house for the defendant. "And the plaintiff shows how he eame to make the house and was ready to do it when the defendant came to him and commanded that he should not

20 " Law of Awarls," p. 32.

neugate $v$. Degelder, 18 Car. IJ, 1 Sid. 281, 2 Keble's Reports, $10,20,24$. 
build the house, on the strength of which he departed." Upon demurrer, both Littleton and Choke held that the plea was a good plea, for, as Littleton says: "If one is retained by me by a deed to be my servant for a year and then I command him that he must not come to my house, etc., and he comes thereafter to my house, I have an action of trespass against him. Therefore here, if the carpenter comes upon my land, after my command that he should not, I may have an action of trespass against him. Ergo, by preventing the carpenter from building the house, the latter was discharged from his covenant and after such a discharge the carpenter has his action in debt for the ten pounds, if he wishes, for there is no defense." It is only by way of argument, at the close of the case, that Vavisour says that "A man can discharge his arbitrator or his auditor after the submission and after they have sat"-an argument which had no bearing upon the case and which in no wise expresses or affects the determination of the judges. The case may be regarded as authority for the main principle decided in Vynior's Case, namely, that the defendant having made it impossible to perform the condition of the bond, the plaintiff could sue upon the bond; but it is in no respect an authority for the right of either party to revoke an agreement to arbitrate.

The last ease eited in Vynior's Case is 8 Edw. IV, 9 and 10 (1468). This was an action upon an award made by arbitrators, and the entire discussion, covering four pages of the Year Book, relates to the question whether it is essential to the lolding of the defendant upon an award, that he shall have had actual notice of the award by the arbitrator. The judges gravely discuss whether or not the plaintiff should have his suit; though it appeared from the pleadings that he had not alleged, that, before the suit, the defendant had notice of the award. They ultimately hold that it was the business of the defendant 
to know of the award, and that it was not necessary to allege and prove actual notice of the award to the defendant before the suit was brought..2

This case is, in reality, an authority for the validity and sanctity of arbitrations, because it appears from the long discussions and debates by the judges who were participating (they included Yelverton, Billing, Markham and Laken) that they regarded the decision as of importance on account of its ultimate effect upon the "Common Weale." Laken says that "Every arbitrament is for the purpose of settling (appease) the controversies and differences (disputes and variances) which are between the parties"; and for this reason he holds that when the parties "submit themselves to arbitration they have notice of the difference which exists between them and have elected one person to be their judge, etc." ${ }_{23}$ Accordingly, he says, "It behooves them to attend before him to know his determination, and they are charged at their peril to take notice of the arbitrament so as to perform it." And he uses as an illustration in his argument the duty of a defendant who has given a recognizance to appear on a certain day before the court. "If perchance the bane is another place, it behooves him to be there at his peril." It will not be a plea for him to say that he did not know of the ehange. Accordingly, says Laken: "If a man is bound by the arbitrament of one and that one awards something . . . it behooves me to perform the arbitrament, to take notice at my peril." Yelverton, who takes a contrary view, nevertheless emphasizes the importance to the "Common-Weale" of the precedent about to be made. In a previous case, $8 \mathrm{E}$.

"See also March, p. 261. "And when the arbitrators hare made their award according to the submission, though they are not bound to give notice, but the partics are to take notice thereof at their own peril, to save the forfeiture of their Bonds, etc.'

Italies ours. 
IV 12 b., ${ }^{24}$ Yelverton had said: "An Arbitrement . . . is used for the Common-weale, for to decide debates and wrongs amongst the people, as fines are" and March explains ${ }^{25}$ that "A fine is so called, because that it doth finem litibus imponere" and accordingly "The proper work or office of an arbitrement is to put an end to controversy." "For," says Yelverton in this ease, "arbitrament is used for the Common-Weale, that is to say, to settle disputes and grievances between people and therefore, like fines, and if the arbitrators can charge a party without giving him a notice, then the people will hesitate (fear and doubt) to submit themselves to arbitration." And, accordingly, finding no precedent to the contrary and doing, as he says, "The savants and the civilians do when a new case on which they have no law to go upon comes before them; they resort to the law of nature, which is the basis of all law and what they deem as being most beneficial to the Common-Weale" -he comes to the conclusion that the award should not be binding without notice to the party against whom the award is made. ${ }^{26}$ It is difficult to understand how anyone can conclude that in these times the courts were opposed to arbitration as a method of settling disputes. Indeed, as March says : ${ }^{27}$ " the Law seems more favorable to Arbitrements, then other Judgments, insomuch as by Arbitrators the strict course and tedious ceremonies of Law Suits which are wont most commonly to weary Suiters (and to dive somewhat too deep into their Purses) are eut off, and shorter decisions by them made, with little or no cost at all." Nor is there any fear in the minds of the judges that their courts are being "ousted of jurisdiction." On the contrary they encourage, in the interests of the "CommonWeale," the final settlement and disposition of contro-

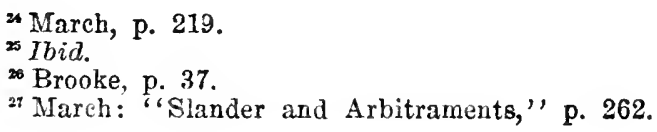


versies outside of the courts. However, in those days precedents were easily lost or misunderstood. March and Brooke make no clear distinction between obiter dicta and decision.

It will be impossible to do justice either to the writers of the days of Mareh and Brooke unless we understand something of their difficulties. Only within the past two decades has there been any scientific study of the sources of the Year Books themselves. ${ }^{28}$ Not until Mr. Horwood and Mr. Pike liad done their work in the Rolls Series upon the unpublished Year Books liad the original manuscript of the Year Books received any study at all. Up to that time the entire legal profession, indeed, the legal historians themselves, accepted as authoritative the printed Year Books or the abridgments published in the sixteenth century.

Describing a large MS. in the Cambridge University library, from which he took the text of the Year Book 20 and 21 Edward I, Horwood "tclls us that, besides the reports of those years, "there is a large body of cases illustrative of pleadings in various writs, and nearly forty consecutive folios (370-409) of cases which, from the names of the judges, must have occurred in or before 18 Edward I' (1290)..$^{29}$ Fitzherbert also used for his Abridgements not only Bracton's Note Book, but also reports which came from 12 \& 13 Edward I (1284-5), as well as a number of undated cases of the time of Edward I." 30 For a long time it was believed that the Year Books from Edward III's reign down to Henry VII's reign were actually arranged by official reporters paid by the Crown itself. This belief was shared by Coke, Bacon and Blackstone. Now, however, such students as Sir Frederick Pol-

${ }^{28}$ See Ifoldsworth: "The Year Books," Vol. II, "Essays in Anglo. American Legal History," p. 96 et seq.

$\approx$ Y. B. 20, 21 Ed. I (R. S.), xv.

${ }^{20}$ Y. B. 2,3 Ed. II (S. S.) ix, x. Holdsworth: "The Year Books," Vol. II, "Essays in Anglo-American Legal History," p. 98. 
lock find this to be without foundation. ${ }^{31}$ We learn that these Year Books owe their origin mainly to the enterprise of private members of the legal profession, ${ }^{32}$ and there is substantial evidence for believing, as Professor Maitland believes, that these are ${ }^{33}$ "students' notebooks." "We see a most remarkable contempt for the non-scientific detail of litigation: especially for proper names. These very often are so violently perverted that we secm to have before us much rather the work of a man who jotted down mere initials in court, and afterwards tried to expand them, than the work of an official who had the faithful plea rolls under his eye." ${ }_{34}$ And again, the fact that there are divergent reports of the same case indicates that the authors "were men writing for themselves, who not only simplified facts, but also expanded arguments, and even invented both facts and arguments." ${ }^{35}$ Again, as Professor Maitland tells us: "The spirit of the earliest Year Books will hardly be caught unless we perceive that instruction for pleaders rather than the authoritative fixation of points of substantive law was the primary object of the reporters." ${ }_{36}$

In the fourteenth and fifteenth centuries, Maitland says: ${ }^{37}$ "Year by year, term by term, lawyers were reporting cases in order that they and their fellows might know how cases had been decided. The allegation of specific precedents was indeed much rarer than it afterwards became, and no calculus of authority so definite as that which now obtains had been established in Coke's day, far lcss in Lit-

"Holdsworth: "The Year Books," Vol. II, "Essays in AngloAmerican Legal History,'” pp. 104, 105.

${ }^{32}$ Ibid., p. 106.

${ }^{33}$ Y. B. 3 Ed. II (S. S.), xii.

"Y. B. 1, 2 Ed. II (S. S.), xiii.

"soldsworth: "The Year Books," Vol. II, "Select Essays in Anglo-American Legal History,' p. 107. See also reference in footnote 2.

${ }^{30}$ Y. B. 1, 2 Ed. II (S. S.), xiv.

${ }^{37}$ Encyclopædia Britannica, 11th Ed., Vol. 9, p. 603, Art. "Eng. lish Law," by F. W. M. [i. e. Frederick W. Maitland.] 
tleton's. Still it was by a perusal of reported cases that a man would learn the law of England." So in the introduction to Brownlow and Goldesborough's Reports (3rd Ed. 1675), the publisher explains to the reader that he thinks it "would prove too obvious a neglect of Common good" to keep these cases "in the dark" and therefore he presents them "to the World," and that as "some few only have hitherto enjoyed by private Copies" he hopes now "that all men may take that benefit by them now being in Print." (Brownlow and Goldesborough were "most Judicious Prothonotaries" of the Court of Common Pleas.) These reports of Brownlow and Goldesborough, as we have seen, contain Vynior's Case reported in two places, placing an emphasis different from Coke's upon the phases of the case in which we are here interested.

Although the records of decisions were valuable things, the practicing lawyer could get access to but a few of them and then only by a lucky chance. Neither the apprentice nor the sergeant could be certain of securing anything like the access to precedents that we find necessary either for purposes of instruction or the preparation of briefs. ${ }^{39}$ There were three abridgers of the Year Books-Statham, Fitzherbert and Brooke. Statham was a reader of Lincoln's Inn in the Lent term of $1471 .^{40} \mathrm{His}$ abridgment was printed somewhere about the year 1495, later editions being published in 1585 and 1679.1 Fitzherbert's was the more complete work, first printed in 1514 under the title "Le Graunde Abridgment" 42 and his work contains extracts from many still unprinted Year Books, as well as from Bracton's Notebook. ${ }^{43}$ Brooke,

\footnotetext{
${ }^{38}$ Italies ours.

"Holdsworth: "The Year Books," Vol. II, "Select Essays in Anglo-Ameriean Legal History,"' pp. 108, 109.

${ }^{\circ}$ Ibid., p. 112.

${ }^{41}$ Ibid., pp. 112, 113.

${ }^{42}$ Ibid., p. 113.

s Ibid.
} 
upon whom Coke relies in his citations in Vynior's Case, based his work largely on Fitzherbert's. Even the printed reports of Richard Tottell of the Year Books are not dependable, for Tottell himself has attempted to make "corrections" 44 and the carelessness with which these corrections have been printed has been only recently demonstrated by Professor Maitland."4 "Of mere, sheer nonsense those old black letter books are but too full." 46

So much for an understanding of the sources of error in the Year Books. Equally instructive is modern research into the origin and sonrces of the English reports. ${ }^{47}$ It is indeed startling to the modern lawyer to learn that, from the last Year Book in 1537 to the year 1865, there were no official reports and that for more than three centuries the work of keeping records of the decisions of the judges was wholly dependent upon private enterprise. Says Veeder: "The most superficial examination of the contents of these volumes reveals the defects which justify" the arraignment made, among others, by Chief Justice Holt. "They will make us to appear to posterity for a parcel of blockheads." ", The manner of making these reports is interesting. "A lawyer," says Veeder, "would preserve in his common-place book notes of the cases eited by him in an argument, and this would be followed by a memorandum of the case in which they were used. He would also add, from time to time, other cases which he happened to hear, or notes of which were shown to him by his professional brethren. If he subsequently attained a judicial station he would of course take notes of the cases argued before him, and, very likely, of eases cited in argument with which he was not

H Ibid., p. 102.

${ }^{45}$ Y. B. 1, 2 Ed. II (S. S.), xxi.

${ }^{46}$ Veeder: "The English Reports, 1537-1865," Vol. II, "Select Essays in Anglo-American Legal History,'” p. 123 et seq.

"I Ibid., p. 125.

${ }^{4}$ Slater v. May, 2 Ld. Raymond 1072. 
already familiar. Such notes were prepared for personal use and without any thought of publication. Their subsequent publication was almost always posthumous." 49 Yet "The note-book of a reputable judge, containing a report of litigation over which he presided, would possess all the elements of authenticity." so We thus understand, for example, the unreliability of eitations such as are used by March for his statement that a submission to arbitration is always revocable. Take, for example, his citation of the case in $28 \mathrm{H}$. VI, 6 . He cites it as anthority for the proposition that, if two plaintiffs and one defendant, or two defendants and one plaintiff, submit to arbitration, neither the one plaintiff without the other, nor the one defendant without the other, may diseharge the arbitrator. IIis reason is "because that they were chosen by the joynt authority of both and therefore eannot be countermanded by one alone." 51 But reference to the case itself shows that it is a stronger authority for the revoeability of the submission than Vynior's Case. The facts disclosed in the Year Book are that one B. sued C. for trespass. C. set up an agreement to arbitrate-whether it was by bond or deed or parol agreement does not appear from the case. B., the plaintiff, sets up that he revoked the appointment of $\mathrm{J}$. B., the arbitrator, and the Court decides for the plaintiff. In arguing against the Court, Pole, for the defendant, says: "You should not go to judgment, for this discharge is void, for one party alone eannot discharge without the other, for he was not elected by one alone, but by the two jointly and therefore it is for them both to discharge. If I and two others submit ourselves to the arbitration of one man indifferently chosen for a trespass committed by those two upon me,

\footnotetext{
40 Veeder: "The English Reports, 1537-1865," Vol. II, "Select Issays in Anglo-American Legal History," p. 125.

Ibid., p. 126.

'1'P. 161.5.
} 
in that case none of them can discharge, and if he does discharge it is void. Therefore here, ete. To which Ashton, Justice, replies: It secms to me to be the contrary, for when one man is elected by two as arbitrator for both, he is elected or appointed by one and also by the other. It is in effect as if onc has appointed one and the other another, in which case each ean discharge the one he has appointed, but in the case where there is one plaintiff and two defendants who have submitted themselves to arbitration and one is indifferently elected by those three, in that case one defendant cannot discharge him, but the both defendants ean discharge him; and therefore here, as if two men appoint one man their agent, one cannot discharge him, but both ean without assent of the third." Accordingly, the justice, having demolished Pole's argument, gave judgment for the plaintiff.

The inaccuracy of the reasoning on the part of the Court is very apparent to modern eyes, for if two, against whom a claim of trespass is made, cannot release each other from the arbitration because of the mutuality of their agreement, it would seem to be equally truc, as Pole argued, that neither of any two parties who bind themselves to arbitration can revoke the agreement without the consent of the other. Pole understood the principle of mutual and reciprocal obligations in a contract. $^{52}$

Ashton reasoned that the arbitrator had reccived power from two principals, and that the legal effect was the same as if each had named separate and distinct attorneys. Therefore, each could revoke. But this is a false analogy. For if two principals on the same side of a controversy appoint an agent to act for both, neither principal may revoke without the assent of the other. The fact that the principals are on opposing sides of a controversy cannot

52 Two years later, 30 Henry VI (1452) Pole himself became a Judge of King's Bench. See Foss: "Judges of England," Vol. IV, p. 353 . 
alter the joint oharacter of the appointment. Hence neither party can revoke without the other's assent. Yet, if the principals were ou the same side of the controversy and a third man were introduced npon the other side, neither principal could revoke without the assent of the other! One can see how immersed in false analogy Ashton was, for even upon the theory of agency, there is no distinction between a submission by two parties to a controversy and a submission by two people on the same side of the controversy. The fallaey lies in treating the arbitration, as March does, as a joint agency. Of course, if it were a joint ageney, it could be revoked only by the united action of the two prineipals; but again, if naming an arbitrator ereates an ageney, then, where two people appoint the same agent, why have they not acted as joint principals and rendered the power irrevoeable save by the consent of both?

It has been said recently: ${ }^{53}$ "The existence of an erroneous doctrine in the law means that some lawyer has been inadequate to his duty. Such a doctrine cannot come into being exeept through a misunderstanding of prineiples and an acceptance of insufficient reasons. At some point in our legal history, therefore, attorneys have not been competent to protect their elients, or judges have rendered judgment upon insuffieient knowledge. We, who inherit a detailed body of jurisprudence, are not adequate to our duty, either as practicing attorneys or as members of the judiciary, if we fail to correct these errors. As attorneys we are not resourceful in protecting our clients' rights, and as judges we are not diligent in studying the principles which we assume to enforee."

When Pole argued in 1450 , as we have seen, there was no published edition of Bracton's notes. We ean hardly blame him, thercfore, for not referring to the early authorities. Nor had he aceess to $49 \mathrm{Edw}$. III (Brode $v$. de

s Abbot, Everett V.: "Justice and the Modern Law," 1913, p. 79. 
Ripple-1375). Even in these days two judges at Special Term may render opposite decisions in cases involving the same questions of fact and law, neither judge knowing his eolleague's opinion. ${ }^{54}$ And frequently, for want of citation of an authority, the Court may fall into error. We should not be too rigorous, therefore, in our critieism of the bench and bar of the fiftecnth eentury, eonsidering the limited number of books available and the limited edueation of the lawyers, for relying upon reasoning, unsupported by precedent, or for falling victim to inaccurate eitation of authorities. ${ }^{55}$

Coke's reports contain no eases decided eariier than the reigns of Elizabeth and James I, and we find in the eompendious index at the end of the Thomas and Fraser edition (1826) not a single reference for the statements eoncerning "Revocation and Subnission," except Vynior's Case, though "Arbitration and Award" cover over a page and a half of notes. The high regard and respeet for Coke's learning and general aecuracy whieh the Bar of his times universally aceorded him, doubtless gave to the obiter in Vynior's Case a standing whieh, as a matter of aecurate legal reasoning, it did not deserve, and which, as we diseover upon the basis of earlier precedents, it should not have been aceorded. Yet it is doubtful whether, before the publication of Klingelsmith's English translation of Statham (1915) and the publieation of Bracton's "Notes" (1887) any English lawyer would have had the temerity to go back to Edward III, re-examine the eita-

${ }^{54}$ See New York Law Journal, June 11, 1917. Decisions by Judges Greenbaum and Bijur, upon substantially the same kind of case, each reaching a conclusion directly opposite to the other's. Universal Film Manufacturing Co. v. Bell, 100 Mise. 281,167 N. Y. Supp. 124; Message Photoplay Co. v. Bell, 100 Misc. 267, 167 N. Y. Supp. 129 .

'W We know that Bracton's Note Book was not available for him, and there is considerable doubt as to whether the Year Book containing the decision of $49 \mathrm{Edw}$. III had yet been printed. See Soule: " Year Book Bibliography,' Harvard Law Review, Vol. XIV, No. 8, pp. $557-587$. 
tions in Vynior's Case, especially Prode v. de Ripple, and distinguish between an obiter dictum and a decision by my Lord Coke. Nevertheless, the references in Vynior's Case to the five or six meager earlier authorities are a compendious eantion to later lawyer's, warning them to examine the earlier eases for a proper evaluation of the dicta. In Vynior's Case, Brooke's "Abridgment" is the primary authority, and he, as we now see, was in error. Yet Nareh accepts this dietum and the reference to Brooke, and eites both as anthorities for the doctrine of the revocability of a submission; and so, thanks to Coke and March, Vynior's Case becomes the respected and controlling authority for a proposition which was not involved in the case. Thus, in 1806, before Chief Justice Ellenborough in Milne v. Gratrix, Vynior's Case is the only case upon this point discussed by the lawyers and they go so far as to concede, upon the basis of its authority, that "At common law the bond (of arbitration) was revocable" (a proposition for which Vynior is no authority at all, for it will be reealled that the plaintiff was permitted to recover upon the bond); and Lord Ellenborough goes even farther and holds not only that the rule as stated was the rule at Common Law, but that even under the statute of William (9 and 10 W. 3. e. 15-by which a submission was made a rule of court) "There is nothing ... to make it irrevocable while it continues executory." Thus is created Milne v. Gratrix-another leading ease.

The judges were conseious of the unsoundness of the rule, but they applied it, because it had become hoary with antiquity. In Aston v. Gcorge, ${ }^{56}$ Abbot, C. J., observes that "there is a material distinetion between a reference under a Judge's order and a reference by deed," and that "when the submission is revoked, there remains nothing which can be made a rule of Court" while "a Judge's

${ }^{2} 2$ Barnewall and Alderson 395. 
order, on the other hand, may be made a rule of court without reference to any statute." Park, J., says in Claphant v. Higham: ${ }^{57}$ "If there were any ground for assisting the Plaintift, the Court would be disposed to do so here." Nevertheless the Court declines to set aside the revocation of a submission made under a judge's order for no other reason than, as Burroughs says: "For thirty years it has always been considered in Westminsterhall that a submission may be revoked at any time before the award is made." We may say with Coke himself: ${ }^{58}$ "Here out (for want of a true and certain report) have sprung many absurd and strange opinions, which being carried about in a common charm, and fathered on grave and reverend judges, many times with the multitude, and sometimes with the learned, receive such allowance, as either beguile or bedazzle their conceits and judgments."

Can anyone now believe that, if the early cases in Bracton and those cited in Statham had been as accessible to the Bar and to the Bench of those times as our early New York decisions are to us, this error in legal reasoning would have so long thrived and bred its fertile and hardy brood of dwarfs? Surely the "common charm" of Vynior's Case is due to its having been "fathered" on a "grave and reverend" judge, thus "beguiling and bedazzling" even "the learned."

${ }^{\mathrm{s} 7} 1$ Bingham 87, at p. 90 .

${ }^{8}$ Introduction to Part I, p. xxvii. 


\section{CHAPTER $X$}

\section{THE EFFECT OF COKE'S DICTUM}

THE first compendious abridgments of English Common Law, comparable in any way with our modern digests, are Rolle's reports in Freneh, published in 1668, and Viner's reports in English, published in 1747. Yet one searehes in vain under the title "Arbitrament" through either of them for any reference to Vynior's Case, or for the doctrine of the revoeability of the submission. Under the title of "Authoritie" in Rolle, we find the following: "

"D. Who can Revoke.

"1. If 2 submit themselves to the award of I. S., one alone ean revoke the submission, 28 II. 6.6.b adjudged, 21 II. 6. 30. Brooke on Abridgment, 5 E. 4, where he is bound by bond to the award, but he will forfeit his bond by revoking, 8 E. 4, 10. b. 21 II. 6. 30. Co. 8. Vinior 82. Contra 5 E. 4. 3, where bound by bond.

"E. Who can revole at law.

" 2 . If 2 on one side and one on the other submit themselves to the award of I. S., one of the said two ean revoke the submission withont the other. Contra 28 II. 6. 6.b."'

Yet, as we have seen, careful examination of 28 H. 6. 6 b. discloses that the case holds quite the reverse."

"3. If $A$ and 13 submit themselves to the award of I. S. and then before any award is rendered, revoke the authority of the arbitrator, that is no revoeation at law un-

"Rolle "s "Ahridgment," Vol. I, p. 331.

ante, IP. 120-104. 
less notice of this revocation is given the arbitrator. Co. 8 . Vinior 82. per Curiam 8 E. 4.10.b.21.b."'

Viner, under "Authority-What shall be said a good, and what a bad, or void Authority," says this: ${ }^{3}$

"4. A man cannot make an authority, power or warrant irrevocable, which by law, and in its own nature, is revocable. 8 Rep. 82 . a. 'Trin. 7 Jac. resolved in Vinyor's Case."

The reporters of these days thus treated Vynior's Case as an authority on "Authority," lather than on "Arbitration." The primary difficulty in these times was in the application of the doctrines of authority to other fields. We must recall that neither Viner, Rolle, Brooke, Fitzherbert or Statham knew anything of the subject of Agency or Contract; they understand letters of attorney to make livery of seizin, and the like.

Lord Mansfield naturally had a surer grip. In 1757 he says :" "Awards are now considered with greater latitude and less strictness, than they were formerly. And it is right that they should be liberally construed; because they are made by judges of the parties own choosing. And this is often (as it is here), in cases of small consequence, where the play is not worth the candle." And in another case: "On a dispute about a church-rate, one party offered a submission: But it was contended, that the matter being originally of ecclesiastical cognizance, they should go for a definitive sentence into that court. Lord Mansfield-Is not a submission stronger than any sentence? If they will not take a submission offered, with payment of full costs, I will consider of it this time twelve-month.", 5

The difficulty of the early attempts to reason by analogy from the subject of "powers of attorneys" is no-

"Viner's “Abridgment," Vol. 3, p. 417.

- Hawkins v. Colclough, 1 Burrow 275, at p. 277.

- 1 Lofft's Rep. 426. 
where better illustrated than in a ease reported by Ventris $^{6}$ (Trippet $v$. Eyre) 1689, in Trinity Term (4 Jae. II). Two arbitrators named in a deed of submission having failed to agree, they named an umpire, and when he failed to serve, they named another. Upon a suit upon the bond accompanying the submission for the penalty of $£ 300$, the court allowed a recovery. The defendant pleaded that the arbitrators having appointed one Jessup as umpire, and said Jessup having refused to serve, they had appointed one Clark; in consequenee, having once exereised their power, the arbitrators could not exereise it again. Here is a clue to the reasoning of the Bar and judges of this day. Powell, Rokeby and Ventris were in favor of the plaintiff. Pollexfen, Chief Justice, was for the defendant.

"But it is objected," reads the report, "that the Arbitrators here have executed their Authority, and 'tis done as fully as ean be on their Parts, and therefore they have no Power to name any other: the Condition empowered them to name one, but not to name a seeond." To which it was answered: " 'Tis true, when an Authority is onee fully exeeuted, the Power is determined; but here, admitting it to be an Authority (uhich Ventris said it uas not properly to be called so, there being no express Authority given to the Arbitrators, but 'tis rather a Description or Qualification of the Person which is to make the Award ut supra) ${ }^{7}$ yet there is no compleat Exeeution." Thereupon the learned judges diseuss what transpires in law in the ease of a "Letter of Attorney be to deliver Seizin, and the Attorney deliver Seizin within the View, which is no good Exeeution of his Authority" and they say: "Yet sure that does not hinder him from delivering Seizin upon the Land," etc. And accordingly, "it was surely the Parties Meaning, if the Arbitrators named

- 2 Ventris 113.

'Italies ours. 
a Man that rejected the Umpirage, that this should not conclude them from naming another;" and so gravely they conclude that the nomination of Jessup was not a nominatiou at all, but a mere proposal. Yet for two pages or more the judges labor with each other to determine whether there might not be two awards. Finally the Chief Justice concludes the discussion with this: "No Case could be put that where a Man that was vested with a bare Authority, his Denial or Refusal to execute it could conclude him; but that notwithstanding he might execute his Authority; but if he makes a void or insuffieient Execution, he may do it over again." In the days when property rights were ehiefly in land, the making delivery of seizin by "letter of attorney" was serious business. Obviously, the exercise of a power was something of grave coneern. Accordingly, once treat the appointment of an arbitrator as the appointment of "an attorney" and all the safe and prudent rules applicable to the creation or exercise of powers of attomey came into the foreground of legal thinking. So we find the judges in this case (Trippet v. Eyre) in 1689 saying: "This is properly an Authority in the Arbitrators; 'tis so taken in Vinyor's Case in $8 \mathrm{Co}$. and is revocable as other Authorities are."

That Coke's dictum in Irynior's Case is based upon the theory of revocability of grants or power's not coupled with an interest is further developed in the reading of the discussion in Freeman's Reports 85, at p. 88, where in Thomas $v$. Sorrell (1673) the Court considers whether or not Letters Patent from the King to sell wine without license is not destroyed by a subsequent general statute of Parliament. Ellis argued that "all bare lieences or authorities were determined by the death of the party that grants them:... But where an interest passes, or where an authority is coupled with an interest, or where a licenee is executed, these do not determine by the death of the party" and it is in this connection he says: "A bare 
authority, though it be made irrevocable, may be revoked", and for this he cites Coke again: "8 Co. Vinior's Case." "It is too often forgotten," says Maitland " "that, until Elizabeth's reign, England was a thoroughly rustic kingdom, and that trade with England was mainly in the hands of foreigners. Also in medieval fairs, the assembled merchants declared their own 'law merchant,' which was considered to have a supernational validity." Thus, says he, "In the reports of the Common Law courts it is late in the day before we read of some mercantile usages which can be traced far back in the statutes of Italian Cities."

The absurd extent to which the English law courts carried this so-called "doctrine of revocability of a power in its nature irrevocable" appears still further in Hide $v$. Petit, ${ }^{\circ}$ wherein a reference by consent of both parties in an action in equity, confirmed by order of the Court, is nevertheless held to be revocable. There we learn that in a cause for "many years depending in court" (and even in Parliament) "an order ras made by consent of both parties, to stand to the award of A. and B. Jolleis, two eminent merchants;" the parties attending upon the reference. "Petit perceiving that the Jolleis would condemn him by their award ... under hand and seal revokes the authority given to the arbitrators, and retracts the submission;" nevertheless the arbitrators go on and make their award. Though the case goes upon two grounds -one "because some matters referred were not determined by the award," the Lord Chancellor (Bridgman), assisted by Rainsford and Wild, J. J., was of opinion, in the main, that "though it were an abuse of the court in the defendant to retract his consent, after he had attended the reference, having first subscribed the consent under his hand; yet such a consent, giving a bare authority

\footnotetext{
"Encyclopxdia Britannica, 11th Ed., Vol. 9, p. 605, art. "English Law."

'Frecman's Ch. Rep. 133; 1 Ch. Cas. 185; 1670. Italics ours.
} 
only, was revocable." (A consent in court to a reference is revocable, because, forsooth, it is a "bare authority." 10 Here we find the Court declaring solemnly "That an

10 The best eriticism of this theory is to be found in Bell "Law of Arbitration in Scotland," p. 267. He says "In its most im. portant legal attributes, the contract of judicial reference is the same, substantially, with the ordinary contract of submission." "I am perfectly sensible that there is a difference between a judicial reference and an ordinary private arbitration. But is it not still a contract. And what is the contract? Instead of taking the chance of the ordinary procedure of the Court, the parties agree that the whole cause shall be determined by the judgment of a referee ap. proved of by the Court. Is it not a bargain-a transaction-a binding contract to that effect? What is it but a submission, taking effect by contract in that particular form? The depending summons, and the minute of judicial consent or request, with the sanction of the Court interposed, constitute the written submission to which the statute of Regulations refers. The particular form, perhaps then unknown, sig. nifies nothing. The substance of the thing, with sufficient form, is quite clearly a submission, within the contemplation of the statute; and that of the most authoritative nature, according to its principle; the contract being entered into, solemnly, in the face of the Court, and ratified by the express order of the Court. The submission being of the depending process, and emanating from the Court, the award must come back there, for the formal judgment on the summons, and warrant for execution. But still, the contract of submission is complete, and the Court ean have no power to infringe the contract. The powers of the Court, as to any matter of judgment on the merits of the cause, have been entirely transferred by the parties, with the sanction of the Court, to another tribunal of their own selection; and all that the Court have to do, is to see that due execution of that contract shall be given. It is impossible that, consistently with this principle, the Court can inquire into the grounds of the referee's judgment, either in law or in fact, when there is a general reference of the cause. That would just be to break up the contract, and take the arbiter's duty, who had been ehosen by the parties for their judge, upon ourselves. And, therefore, I cannot give any weight to the general reasoning here employed, as to the supposed distinction, generally, between a judicial reference and an extra-judicial arbitration. Both are submissions, making contract for judgment; and surely the judicial contract is the more sacred of the two.' Per L. Moncreiff, in Brakenrig (Dec. 17, 1841, 4 D. 274). Italies ours.

"When parties have by contract agreed to a judicial reference, that is a contract like any other contract, and the Court has no more authority to put an end to that contract than they would have to put an end to a contract for the sale of an estate or the lease of a bouse: it is irrevocably binding upon the parties, unless they have stipulated some mode by which they may get out of that binding contract." Per L. Cranworth, C., in Walker \& Co. August 14, 1855, 2 Macq. 424, at p. 829. 
authority in its nature is revocable by law, though referred by order of court." So indignant, however, is the Court at the conduct of the defendant "for his abuse of the court in retracting his consent" that it promptly issues an attachment against him to show cause why he should not be punished for contempt-or, as it is reported in Ch. Cases (p. 185) - "it was an abuse to the court, as it was conceived, to revoke it, for which the court might justly lay the party by the heels." The doctrine of estoppel seems not to have been discussed or considered in the case. Yet in Bishop v. Bishop, ${ }^{11}$ where an award was made by Mr. Justice Crook on a reference of both parties, it was held (Sir Edward Littleton, Lord Keeper) that if one of the parties to the award performed his part, the Court of Chancery would compel the other to perform his, even though the arbitrament was not made by direction of the Court.

Two years after Hide v. Petit, a Bill is filed in Chancery ${ }^{12}$ and, an account being directed, the matter is referred to one Phillips "by Consent of all Parties, and his 'Award to be conclusive." Phillips makes his award and the defeated party takes exceptions; but the Court ${ }^{13}$ held: "That the Parties having bound themselves by Consent, they would not look back into the Award, and thereupon it was confirmed by the Lord Chancellor." ${ }^{14}$ And in $1685^{15}$ we discover Norton $v$. MIascall concealed in the comparatively unknown "Reports of Cases in Chancery," Vol. II, at p. 304-a case begun in the reign of Charles II and running over into the reign of King James II-in which the following appears:

A bill is filed in chancery to secure and enforee the performance of an award made by arbitrators upon "a

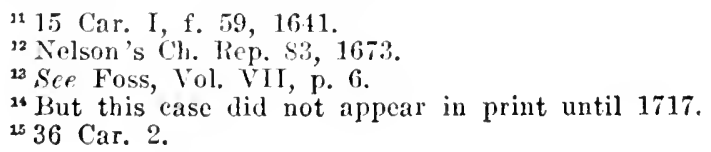


voluntary submission." (Nothing is said about a deed of submission or a bond with penalty-apparently it is a mere submission by contract-though probably in writing.) The defendant "insisted, It being a voluntary Submission of the parties, and the Reference not directed by this Court, the Award was void, and ought not to be performed." And, accordingly, he demurred to the Bill. The Master of the Rolls, Lord Guilford, "ordered Presidents, and upon reading of the Award, declared, he saw no Cause to relieve the Plaintiff, but dismissed the Bill." But the case was "Re-lieard by the Lord Chancellor Jefferies, who declared, he saw no cause why the said Award should be impeached; but it was fit that the same should be performed, being in part executed and assented unto, and decreed the same to stand confirmed, and the Defendant to perform the same."

The Chancellor Jefferies here referred to is none other than the notorious Baron Jeffrcys, whom a contemporary English judge, Mr. Justice Foster, described as the "very worst judge that ever disgraced Westminster Hall;" "16 and the decision is rendered almost contemporaneously with Jeffreys' holding of the "bloody assizes," the conduct of which branded his name with "indelible infamy." 17 Though the decision in the case, as we now perceive, is a clear and unmistakably sound application to the subject of arbitrament of the equitable remedy of specific performance, it reposes quietly in this little used and comparatively unknown volume of "English Chancery Cases" and goes down the centuries unheralded and unsung of reporters or digest-makers, while a mere dictum of my Lord Coke is elevated to the sanctity of settled and controlling doctrine. But my Lord Coke was "the greatest lawyer of his day"-his success in Shelly's Case brought

${ }^{16}$ See Foss, Vol. VIT, p. 226.

${ }^{17}$ See Encyclopædia Britannica, 11th ed., Vol. 15, p. 309. 
him a praetice "never before equalled." is The reputation of Coke's Reports was so great, Soule tells us, "that for a long time they were eited simply as 'The Reports' ('Rep')." ${ }_{12}$ Yet with all due respect-even homagefor Coke's learning, he, too, had his faults. He was intensely arbitrary, exceedingly brutal in speech, and if we are to believe Bacon, his intense rival, wandered from the points of a case and often talked too mueh. Bacon once wrote Coke: "In discourse you delight to speak too much, not to hear other men. This, some say, becomes a pleader, not a judge; for by this sometimes your affections are entangled with a love of your own arguments, though they be the weaker, and rejecting of those which, when your affeetions were settled, your own judgment would allow for strongest. Thus while you speak in your own element, the law, no man ordinarily equals you; but when you wander, as you often delight to do, you wander indeed, and give never such satisfaetion as the curious time requires." ${ }^{20}$ Coke, it will be recalled, resisted the power of Chancery to tonch any cause in the Courts of Common Law and even encouraged indictments of those who applied to the equity courts for relief. In one case pending in the Common Law courts he indicted the counsel and solieitor to the parties and even the Master in Chancery to whom it had been referred. ${ }^{21}$ It required an appeal to the King to reverse him and to confirm the Court of Chaneery in all the powers which it claimed, which decision is acted upon, as Foss says, "to this day." "21 "The independence of his eonduct as a judge" was "not unmixed with the baser elements of prejudice and vulgar love of authority." "Full of an extreme reverence for the Common Law which he knew so well, he defended it alike against the eourt of chan-

${ }^{28}$ Encyclopedia Britannica, 11th Ed., Vol. 6, p. 654.

"Soule's Lawyers' Reference Mamul, p. 92.

"Foss: "Judges of England," Vol. VI, pp. 118-119.

${ }^{21}$ Ibid., p. 117 . 
cery, the ecclesiastical courts, and the royal prerogative" and the verdict of history upon this score is that "he sought to prevent the interference of the court of chancery with even the unjust decisions of the other courts." 22 The common bond between equity and the lex mercatoria has already been indicated by Carter in his "History of English Law." 23

We have but to contrast the liberating influence of Lord Mansfield with the conservative tendencies of Coke to realize why, in Coke's time, the strict adherence to the forms of the Common Law retarded the development of such simple principles as estoppel, mutual assent, and the specific performance of contracts.

Jeffreys, whose understanding of equity principles and procedure is shown in Norton $v$. Mascall to be keener than Coke's, secures for his decisions no such respect or authority as is freely accorded to Coke-thus contemporary history punishes the unscrupulous intellect by burying its good and exposing its worst. "The evil that men do lives after them, the good is oft interred with their bones."

Nor was Coke always accurate. Says Veeder: "Sometimes, as in Gage's case, ${ }^{24}$ he gives a wrong account of the actual decision. Moreover the authorities which he cites do not always sustain his conclusions. ${ }^{25}$ This fault, indeed, runs through all his writings and has carried in its train some unfortunate consequences." ${ }_{26}$ The similarity between the error of Coke's dictum in the field of commercial arbitration with his error in Pinnell's case ${ }^{27}$ is most striking. Here, says Veeder, ${ }^{28}$ "by giving a mere

${ }^{22}$ Encyclopædia Britannica, 11th Ed., Vol. 6, p. 654. Italics ours.

See ante, pp. 79-80.

2 5 Rep. 45b; see 1 Salk. 53, and Will. 569.

${ }^{25} \mathrm{See}$ Jones on Bailments 41 , as to Southeote's case, 4 Rep. 83b, and 1 Inst. 89a; Stephen's "History of Criminal Law," ii, 205.

${ }^{28}$ Veeder: "The English Reports, 1537-1865," Yol. II, "Select Essays in Anglo-American Legal History," p. 132.

${ }^{27} 5$ Rep. $117 \mathrm{a}$; Co. Litt. 212b; see Foakes v. Beer, 9 App. Cas. 605.

28 Veeder: “'The English Reports, 1537-1865,' Vol. Ir, 'Select 
dictum the form and effect of an actual decision upon a point in issue he fixed upon English law the rule that a creditor who, on the day his debt falls due, accepts a smaller sum in satisfaction of the whole, but executes no deed of acquittance, is not bound by his agreement." With the consequence, as Sir George Jessel said in Couldery $v$. Bartrum, ${ }^{29}$ that, according to English law, "a creditor might accept anything in satisfaction of his debt except a less amount of money. He might take a horse, or a canary, or a tomtit if he chose, and that was accord and satisfaction; but, by a most extraordinary peculiarity of the English Common Law, he could not take $19 \mathrm{~s} 6 \mathrm{~d}$ in the pound." "Yet," says Veeder, "the House of Lords in 1884 held that the error was so firmly established that it did not come within their province to correct it." ${ }_{30}$ And in the limitations of the rule and some of the distinctions engrafted upon it by judges who tried to limit the operation of what they believed to be an crroneous principle, we shall find again a striking analogy with the experiences resulting from Coke's erroneous dictum in Vynior's Case. "I am afraid," said Chief Justice Best, "we should get rid of a good deal of what is considered law in Westminster Hall if what Lord Coke says without authority is not law." 31 This is not the only incident in the evolution of mercantile law that has been difficult of understanding to business men. In Clerke $v$. Martin, the great Lord Holt made what Cranch ${ }^{32}$ calls "a hasty, intemperate decision .. . which was acquiesced in by the other judges, in consequence of his overbearing authority,

Essays in Anglo-American Legal History,'" pp. 132-133. Italics ours.

" 19 Ch. Div. 399.

so Veeder: "The English Reports, 1537-1865," Vol. II, "Select Essays in Anglo-American Legal History,' p. 133.

st Italies ours.

"Cranch: "Promissory Notes before and after Lord Holt," Vol. III, "Select Essays in Auglo-American Legal History," p. 92. 
'which made others yicld to him;' and that he so 'pertinaciously' adhered to his opinion, as to render it necessary to apply to parliament to overrule him." ${ }^{33}$ In this conneetion, it is interesting to discover that the old judges were not frce from human infirmity. In Clerke $v$. Martin the report indicates that for some reason or other Lord Holt was exceedingly irritated "with the goldsmiths of Lombard Street, and that his mind was not in a proper state for calm deliberation and sound judgment." 34

Reference has already been made to the fact that Coke's reports were held in so high an estimation by his contemporaries that they were cited simply as "The Reports." ${ }_{35}$ In fact, during the period when they were being issued no others appeared, "as it became all the rest of the lawyers to be silent whilst their oracle was speaking." ${ }_{36}$ Coke's ultimate suspension from judicial office by James I, it will be recalled, was accompanied by a regal command to "consider and revise his reports." ${ }_{37}$ Notwithstanding this, he reported only five trivial errors. His reports, in the opinion of Veeder, "are not reports

${ }^{83}$ Lord Holt held, overruling all previous eases and totally changing the law as to promissory notes, admitting inland bills of exchange to be within the custom of merchants, but denying that privilege to promissory notes. It took the statute of Anne to reverse Lord Holt and confirm the older authorities shaken by his decision that notes in writing were negotiable instruments governed by the Law Merchant. Says Cranch: "By eomparing this act with the cases decided prior to Clerke $v$. Martin, it will be found to contain no principles but such as had been fully recognised by the courts of law. It follows, therefore, that it was passed simply to restore the old order of things, which had been disturbed by Lord Holt."

${ }^{34}$ Cranch: "Promissory Notes before and after Lord Holt," Vol. III, "Select Essays in Anglo-American Legal History," p. 91. ${ }^{35}$ Veeder: "The English Reports, 1537-1865," Vol. II, "Select Essays in Anglo-American Legal History," p. 130.

${ }^{86} 5$ Mod. viii.

37 Veeder: “The English Reports, 1537-1865," Vol. II, "Select Essays in Anglo-American Legal History,' p. 131. 
at all in the strict sense of the term." Veeder calls our attention to the fact that Coke himself says in his preface, " that he prepared his reports not merely for citation in court but also for educational purposes; and to a large extent, though just how far it is impossible to say, they contain his own statement of the law. . . Since, to Coke's mind, the art of pleading was the necessary foundation of all accurate knowledge of the Common Law, the pleadings are fully set out, not only for a proper understanding of the case but for the instruction of students as well." 38 He himself describes his own method: ${ }^{39}$ "And now that I have taken upon me to make a report of their arguments, I ought to do the same as truly, fully, and sincerely as possibly I can. Howbeit, seeing that almost every Judge had in the course of his argument a peculiar method, and I must only hold myself to one, I shall give no just offense to any, if I challenge that which of right is due to every reporter, that is, to reduce the sum and effect of all to such a method, as, upon consideration had of all the arguments, the reporter himself thinketh to be fittest and clearest for the right understanding of the true reason and causes of the judgment and resolution of the case in question." Yet, says Veeder, "His method of presenting what was decided is, however, disorderly in the extreme. Throughout all parts of the report, but particularly in giving the resolutions of the judges, his inexhaustible learning breaks forth; 'one case is followed by another, quotation leads to quotation, illustration opens to further illustration, and successive inference is made the basis for new conclusion; every part, moreover, being laden with conclusions and exceptions, or protected in a labyrinth of parentheses, until order, precision, and often clearness itself is lost in the perplexing though imposing " Veeder: "Tho English Reports, 1537-1865," Vol. II, "Select Essays in Anglo-American Legal History,', p. 131. Italies ours.

su Calvin's Case, 7 Rep. 4 a. 
array." "so Yet he assures the reader that "although he may not, at any one time, reach the meaning of his author, yet at some other time and in some other place his doubts will be cleared."

*Veeder: “The English Reports, 1537-1865," Vol. II, “Seleet Essays in Anglo-American Legal History,' p. 132. 


\section{CHAPTER XI}

WHEREIN LORD COKE'S DICTUM IS NOT FOLLOWED

ANother great intellect succeeded Coke as Chief Justice of King's Bench. Vynior's Case was decided before Coke, as Chief Justice of the Court of Common Pleas. Afterwards he became Chief Justice of King's Bench. He was succeeded when Sir Henry Montague took the office in 1616. Four years later, in Trinity Term (18 Jac.), there came before King's Bench an action on the case in assumpsit to abide by the award of J. S. Sir Montague, before his elevation to the bench, had for many years been Recorder of the City of London, and upon his resignation from that position, the Corporation of London presented him with two hundred double sovereigns "as a thankful remembrance for his many careful endeavors for the city." 1 While passing through this experience he must have seen something of the merchants' boards and tribunals of arbitration then and for a long time previous in operation in London. It is no surprise, therefore, to find him recording as law what is even for our times a very clear statement of the principles of contract applicable to submissions-especially the principle of "mutual assent"-principles so much a matter of common acceptation in our day that it is a constant source of surprise to find them so little applied-or even suggestedin Coke's day.

"It was Resolved," runs the report in old French, by the whole court, "that mutual promises to abide by the award of certain men are good enough to bind them to

"Foss: "Judges of England," Vol, VI, p. 168. 
abide by the agreement and that though no money was due at the time of the promise." Yet Dodridge, J., said, in dissent, "That, in this ease, if the award be that one of the parties shall pay money and the other shall do something this is not a good award."

And so is Ashton, the judge, overruled and Pole, the lawyer, vindicated. ${ }^{2}$ Yet this ease is nowhere abridged, nor is it heralded as a leading case. Quite by accident in our search we found it in the quaint original French in 2 Rolle's Reports, at p. 194, under the title of "Browne $v$. Downing." March does not refer to it; neither Viner nor Rolle abridges it, nor is it to be found in any of the text writers upon the subject. But in point of legal value - Vynior was at Common Pleas and was earlier in date -it is superior as a binding precedent to Vynior's Case.

Earlier still (1617), in King's Bench, Montague refuses a writ of prohibition to a plaintiff who seeks to set aside an award made by arbitrators upon the ground that he has newly discovered documents "which had come into his hands," justifying the setting aside of the award. Per Curia (Sir Henry Montague, C. J., John Croke, John Doderidge and Robert Houghton ${ }^{3}$ ) decides:

"An arbitrament is res judicata" and "it is the settlement of all controversies and if prohibition were allowed (in this case) then every award could be put to question." (Pur ceo que un Arbitrement est res judicata, $\&$ est fine de controversies, \& si ceo serra suffer chescun agard poet estre trahe en question.) This case, also, we found by accident, in 1 Rolle 380, decided 14 Jac. Banco Rex. Easter Term, under the title "Jones vs. _-."

In 1761 we come to a decision rendered in King's Bench while Lord Mansfield presided in that court. In Rex $v$. Wheeler ${ }^{4}$ it appeared that Wheeler had bought two pipes

Ante, pp. 122-124.

See Foss, Vol. VI, p. 14.

- 3 Burr. 1257. 
of wine from one Tulk, and Wheeler asserted that this wine was adulterated and bad, and therefore refused to pay for it. Whereupon Tulk sued him. At the trial, as the report says, "the matter was, by consent of both parties, (probably, to conceal the secrets of the trade, and the nature and degree of mixing), referred to the arbitration of one Mr. Charles Corderoy; Whecler consented to abide by his award, and Not to bring any bill in Equity." (The italies are as they appear in the original report.) This agreement was made a rule of court. Corderoy, the arbitrator, decided that Wheeler should pay Tulk about $£ 20$ for the wine. Wheeler refused to abide by this award. Instead, he moved to set aside the award. The Court heard him and refused to set aside the award, and then he paid the money. But he proceeded to the Court of Chancery, and, as the decision tells us, "was so ill advised as to bring a long bill" to restrain the enforcement of the award. Now reads the report: Thereupon, this Court brought him for contempt. On the brink of being sent to jail, he came to terms, paid all the costs and all the out-

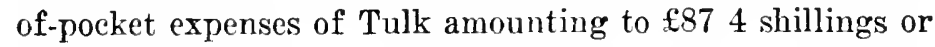
over four times the amount of the award. The Court thought this was punishment enough; that "he had smarted scverely: and yet, as his contempt was so obstinate, they did not eare that a slight sentence should stand upon their records." 5 Moreover, they thought "that the attorney and counsel were equally guilty of the contempt, and more criminal; and if it ever happened again, they would proceed against them."'s The reporter's admonition in the note has high moral value: "This case is a strong proof how far a contentious spirit, with bad advice, may go." And: "No man would accept of being an arbitrator, if he was liable to be harassed with a Chancery-suit for his pains." And this case later on is referred to as

-Itadics the Court's. 
authority in Davila $v$. Almanza ${ }^{6}$ where a matter having been referred by the Court at nisi prius to the three foremen of the jury, and, before the award was made, one of the parties having served the arbitrators with a subpoena. out of Chancery, "which hindered the proceeding to make the award," the Court held this a breach of the rule, and granted an attachment against the offender.

But even in Coke's days, though some of the judges were highly technical, it will be observed that not one of them finds anything contrary to public policy or of the nature of "ousting the courts of jurisdiction" in these arbitraments or agreements to arbitrate. With all his jealous preservation of the Common Law court's jurisdiction -fighting even the King for the maintenance of its power - Coke permits the plaintiff to recover upon an arbitration bond where the defendant revokes the submission. The attitude toward arbitration of all the judges is throughout most friendly. Their difficulties are difficulties of legal reasoning and of procedural machinery, not of equitable purpose. All things considered, they produced fair results. You could plead in bar to trespass that there was an arbitration pending. If the award was made, it was res judicata. If the defendant broke his obligation to submit to arbitration, whether by revocation or otherwise, you had your bond-which was a very valuable remedy. You could in those days fix the penalty and the bond in any sum adequate to protect your client's rights in case the other party breached, and if he revoked the submission or interfered with the submission, he thereby made your bond enforceable. Thus in Noble and Harris (reported in III Keble's Reports 745-29 Car. II B. R. 1688), the plaintiff sued on a bond, given "on condition to perform an Award." The defendant pleaded no award. The plaintiff then set out the award and assigned the breach. The defendant rejoined that before the award was made, the

- 1 Salk. 73. 
defendant revoked and the plaintiff had consented to the revocation. Upon the plaintiff's demurrer, it was held per Curiam - "the Revocation being a breach, its not aided by consent or agreement after, but if it had been said to be revoked by consent of the Plaintiff, the penalty had been saved." Thus, Judgment for the Plaintiff on the Bond. Not even subsequent acquiescence in the revocation by the plaintiff could save the defendant from the penalty on his bond; only revocation by mutual consent could produce such a result.

In those days, fines and penalties were enforceable and quite the mode for obtaining satisfaction for breaches of obligations. When fines and penalties were abolished"but that's another story."

We may now recapitulate the elements which furnish explanation for this case of "arrested development" in our Common Law.

1. A mere obiter dictum, by process of repetition, becomes a doctrine of the law.

2. It becomes doctrine by virtne of the circumstance that (a) March, the first text-writer on the subject and almost every subsequent text-writer states the dictum as though it were final and settled doctrine; and (b) the case in which the dictum is uttered is dignified out of all proportion by the fact that Coke decided it and reported it as a leading case.

3. No comparative study is made of the earlier authorities.

4. Though there are earlier cases of clear and convincing reasoning and equal authority (especially Brode v. de Ripple, $49 \mathrm{Edw}$. III) they are either wholly ignored by March or merely eited without consideration by Coke in $7 \mathrm{Jac} .1$ (Vynior's Case).

5. Though there were three abridgments of the Year Books-Statham, Brooke, and Fitzherbert-March and Coke refer only to Brooke. 
6. Brooke does not disclose the case in $49 \mathrm{Edw}$. III (Brode v. de Kipple) but Statham and Fitzherbert do.

7. Of all the cases cited for the obiter dictum in Vynior's Case, only one (28 Henry 6) supports it and at least two are against.

8. The original error in reasoning occurs in 28 Henry 6 , where Pole, the advocate, as we now see, is right, and Ashton, the judge, is wrong; but neither refers to the earlier cases.

9. Bracton's Notes, which would have disclosed still earlier precedents contra to the dictum in Vynior and the statement in March, had not yet appeared in print.

10. At the time of $7 \mathrm{Jac}$. the Courts were concerned with such matters as seisin, feoffment, seal and the like, and while deeds and bonds and indentures had value, executory contracts resting upon mutual consent were treated as ex nuda pacta.

11. The administration of law was enmeshed in a tangle of formal pleading, and an action for damages for breach of simple contract was as yet unknown.

12. The English judges had not yet come in contact with the customs and experiences of merchants (Lord Mansfield came more than a century later) and so that which was of daily occurrence in the merchants" courts or fairs was as yet no part of the English common law.

13. The respect for precedent and form precluded the scientific re-study or re-examination of the law under new conditions.

14. The art of reporting was in its infancy, and judges, as well as lawyers, suffered for want of accessible and accurate reports or digests.

15. Later precedents of greater binding authority were ignored by abridgers and buried in forgotten reports. 


\section{CHAPTER XII}

\section{THE PASSING OF FINES AND PENALTIES}

To establish damages for the breach of a contract requires detailed proof of actual injury, and under the strict rules of evidence the injured party ofttimes fails to reeover all that he is entitled to for want of teehnical proof. This practical difficulty led very early in the making of contracts to the fixing of a penal sum or fine which the parties obligated themselves to pay eaeh to the other, in the event of a breach; that is to say, if A agreed to build a house for $\mathrm{B}$ and to have it finished by Michaelmas, $\mathrm{A}$ would agree that in case the building was not completed by that day he would pay a penalty of $£ 5$ per day. Before the statute of 8 and 9 William III, recovery was allowed for whatever penalty was fixed in such an agreement. ${ }^{1}$ As the practice grew, penalties beeame the common form of fixing damages, and, regardless of the actual barm that resulted from a breach, the penalty was enforceable. Thus though $A$ 's failure to finish the house by Michaelmas might have caused no real damage to $B$ at all, nevertheless the penalty would be recoverable.

Gradually public opinion began to discountenance this method of fixing damages by way of punishment. The idea of recompense, rather than penalty, was more native to English justice. Accordingly, courts of equity began to accord relief; that is to say, in cases of fraud or extremity or accident, they would limit the strictly legal remedy for the penalty so as to cover the actual damages

'See Whitficld v. Levy, 35 N. J. Law Reports 149. 


\section{THE PASSING OF FINES AND PENALTIES 149}

sustained by the injured party. ${ }^{2}$ This was permitting compensation on what was called an issue of quantum damnificatus. ${ }^{3}$ The statute of 8 and 9 William III was intended to limit the injured party to recovery of actual damages arising out of default in the performance of an agreement regardless of the penal sum fixed in the contract, so that in a suit at law after the enactment of this statute the injured party would secure substantially the same measure of relief in a suit at law upon the contract as might have been obtained by the intervention of a court of equity. In short, the purpose of the statute was to harmonize the law as it existed in the Courts of Chancery with that of the Common Law Courts and to limit the plaintiff to his actual damages, in an action of debt for the penalty, the measure of recovery being neither advanced to nor limited by the sum named as a penalty. What was recovered by the plaintiff was his actual damages, whether they were greater or less than the penalty. ${ }^{4}$ Later on the courts held that penalties fixed in an agreement or bond were against public policy, and even where the parties did not use the term "penalty" but used the words "liquidated damages," the courts would not enforce the clause. If the court could see from the whole instrument taken together that there was no intention that the entire sum should be paid absolutely on the non-performance of any of the stipulations of the debt, they would reject the words and consider it as being in the nature of a penalty only. $^{5}$ And conversely, even if the parties used the term "penalty," but it was clear that it was intended to be

2Cary's R. 1; Harvard Law Tracts 431.

' 2 Story's Eq. Jur., $\$ 1314$. The earlier cases are collected in an elaborate note by Mr. Evans in his edition of the English statutes; 'Evans' Statutes," Vol. 3, p. 324.

'Winter v. Trimmer, 1 Wm. Black, 395; Marrison v. Wright, 13 East 343; Lowe v. Peers, 4 Burr. 2225; 1 Saund. 58 c.

'Parke, B., in Green v. Price, 13 M. \& W. 695, at p. 701; Kemble v. Farren, 6 Bing. 141; Horner v. Flintoff, 9 M. \& W. 678; Shiell v. $M$ 'Nitt, 9 Paige 101 . 
liquidated damages, they would permit the recovery. Thus in Sainter $v$. Ferguson, ${ }^{6}$ a doetor agreed not to practice at MI. or within a radius of seven miles of M., "under a penalty of $£ 500$." The Court held that the $£ 500$ was not to be treated as a penalty, but as liquidated damages, Coltman, J., saying " Although the word 'penalty,' which would prima facie exelude the notion of stipulated damages, is used here, yet we must look at the nature of the agreement, and the surrounding cireumstances, to see whether the parties intended the sum mentioned to be a penalty or stipulated damages. Considering the nature of this agreement, and the diffieulty the plaintiff would be under in showing what speeifie damage he had sustained from the defendant's breach of it, I think we ean only reasonably construe it to be a eontraet for stipulated and aseertained damages."

Now there was nothing more diffieult for the old draughtsmen of contracts in safeguarding their clients' interests than to draw an agreement of arbitration whieh would be effeetive in ease of a breach. If $\mathrm{A}$ and $\mathrm{B}$ agreed to submit to arbitration a difference between them, in case $B$ revoked the arbitration what were A's damages? The very subject matter of the eontroversy was in dispute. If A claimed that B owed him a thousand pounds and B claimed that he did not, of eourse, if $\mathrm{B}$ revoked the arbitration A's damages could hardly be treated as one thousand pounds. Whether or not he was entitled to the thousand pounds was dependent upon the decision of the arbitrator, and if the arbitrator made no decision, as, of course, he eould not, after the agreement was revoked, how were you to fix A's damages exeept by trial? So long as it was permissible to fix a penalty, you could easily say that, in ease either party revoked, in such a ease as the one suggested, he should pay to the other, say, five hundred pounds. But obviously, this is a penalty, and

$\circ 7$ M., G. \& S. 716 , at p. 727. 


\section{THE PASSING OF FINES AND PENALTIES 151}

under the rule gradually established in courts of equity and finally made into statute law by the enactment of 8 and 9 William III, it was void. In consequence, the relief which Vynior secured upon the bond when Wilde broke the agreement to arbitrate was no longer to be obtained. All that you could recover was the damages that you sustained by reason of the defendant's refusal to go on with the arbitration, and, as Fletcher Monlton says in Doleman \& Sons $v$. Ossett Corporation," "It will be evident, however, that the remedy in damages must be an ineffective remedy in cases where the arbitration had not been actually entered into, for it would scem difficult to prove any damages other than nomiual." So that the result of Coke's dictum in Vynior's Case, plus the enactment of the statute forbidding fines and penalties, was to leave the injured person practically without remedy. He could sue for his damages, and the damages would be limited to the nominal expense that he had been put to in preparing for the arbitration. What he really wanted was either a fixed penal sum upon which he could rely at the moment he entered into the agreement to arbitrate, or else some judicial machinery by which the recalcitrant defendant could be forced to go on with the arbitration. In other words, what should have been granted to him was specific performance; that is to sav, the defendant should be required to submit to arbitration. If he failed to nominate his arbitrator, then the court should have been permitted to nominate someone for him, and the arbitration should be proceeded with. The abolition of fines and penalties, therefore, brought about the present incongruous state of the law where the party injured by breach of an agreement to arbitrate is practically without remedy. First, the courts limited the party to his action upon the bond; then they took away the penalty on the bond; then they said they would not enforce the agreement by specific per-

${ }^{7}$ L. R. [1912] 3 K. B. D. 257, at p. 268. 
formance, and thus they left the situation in such shape that the clever but dishonest merchant can speculate on the outcome of an arbitration, and. when he sees how the arbitrator's mind is going, withdraw from the arbitration without danger of any substantial liability. 


\section{CHAPTER XIII}

\section{"OUSTING THE COURTS OF JURISDICTION"}

To discover the genesis of this phrase as applied to covenants of arbitration, we have gone to the reports of the cases of the days in which it originated and examined them volume by volume, disregarding for the purposes of the search all of the digests and reviews. We think it may be safely said that the roots of this curious doctrine of the law are to be found in the following group of cases:

Kill v. Hollister, in King's Bench (18 Geo. II 1746) (1 Wils. 129). The report of this case requires but eleren lines. The action is upon a policy of insurance. The policy contains a clause that, in case of any loss or dispute, the matter shall be referred to arbitration. The plaintiff sets up that there had been no reference. Upon the trial at Guildhall the point is reserved for the consideration of the Court, whether this action is well laid before there has been a reference. And by the whole court it was decided that, if there had been a reference pending, "or made and determined, it might have been at (sic) bar, but the agreement of the parties cannot oust this court;" " and as there has been no reference nor is any pending, "the action is well brought. . . ." There is no discussion and no citation of authority. Observe that the Court would regard the defense as good if the arbitration were pending.

Fill $v$. Hollister is cited and discussed in Mitchell $v$. Harris (1793), 2 Vesey Jr.'s Reports 129, at p. 131.

${ }^{1}$ Italics ours. 
The latter case is a bill for a discovery in aid of a suit over partnership articles. It was pleaded in bar that the articles contained a covenant to refer all differences to arbitration. The Attorney General, Sir John Scott, afterwards Lord Eldon, ${ }^{2}$ and Mr. Mansfield for the Plea say:

"There is no sense, in what is said in Kill $v$. Hollister, 、 1 Wils. 129, that such covenants cannot be permitted, as the agreement of the parties cannot oust the jurisdiction of the Court. It is not ousted more than by a release of all right of action." Was he right?

The Solicitor General for the other side admits in the course of his argument "that an action might be brought against them for not bringing it to arbitration," to which Lord Chancellor Loughborough said: "Do you know any case, in which an action has been brought on such a covenant? In that case in Wilson (meaning Kill v. Hollister) it came out in evidence upon the assumpsit. Suppose an action brought upon the covenant for not referring it, but proceeding at law; what would be the damages?"

To which counsel reply: " "If there were only nominal damages, it would make the point good ... Lord Hardwicke says, this Court must give relief upon a bill for discovery, in order to go to arbitrators, for this extraordinary reason, that it is not suitable to the dignity of this Court to give a discovery for the purpose of an arbitration." II refers to Wellington v. Mackintosh, 2 Atk. 569 (1743). To which the Lord Chancellor said: "There is no doubt, that the reporter has mistaken Lord Hardwicke's reasonts in that case. He has only taken down part of what was said, and has misapplied that; but still the case stands as a clear authority, that the plea was

\footnotetext{
${ }^{2}$ Encteloyædia Britannica, 11th Ed., Vol. 9, pp. 166, 168.

There is cited a footnote reference to Rowley $v$. Young, 3 Day 118, where, after revoration, the plaintiff is permilfed to recover the cosis ol' the suit at law, as well as floose arising under the submission. Italices ours.
} 
overruled." The argument of the Court here runs: "It struek me, that no such clause could by possibility stop the discovery; but that some time or other a discovery of the matters supposed to be concealed must be had. This is not inconsistent with a subsequent submission to arbitration. The discovery will leave the party to decide whether to bring an action or not." What was here considered was how to give the plaintiff discovery, if he needed it, either before or after the arbitration; there is nothing in the Court's opinion indieating that it regards the clause itself as void or against publie poliey.

Then comes this suggestion: "There is another clause in these articles, that the award shall be final. That is more than the law allows to any judgment. If a judgment at law was obtained, a bill showing that it was obtained against conscience by eoneealment, would open it to relief in this Court. If matter of Equity arose out of the award, I take it, the Court would open it." But the learned Chancellor misunderstood the meaning of "final." It was no more final than a release. Equity could relieve upon the same familiar grounds as it could relieve from a release obtained against conscience or where matter of equity could be shown. And so eounsel for the plaintiffs said to the Court: "In Burton v. Ellington, in the Common Pleas, your Lordship determined, that where evidenee is fraudulently withheld before arbitrators, you would not prevent the party from going to a Court of Equity for a discovery." Whereupon the Lord Chancellor says: "Certainly not" and then puts this question: "Have you found any case, in which an agreement to refer has been set up as a bar to an action?"

The very early authorities whieh we have reviewed are not brought to the Court's attention; there is no consideration given to the law of arbitration generally, no consideration of its history or use; no text-writers on the

- 2 Ves. Jr. 129, at p. 135. Italies ours. 
subject are consulted. The Court aceepts the unreasoned expressions in Wilson (Kill v. Hollister) as the only existing authority at Common Law upon the subject, the Chancellor saying: "I have looked into many cases at law, where the subject of reference beeame afterwards the subject of action; and it is not said in any, that a mere agreement to refer can take away the jurisdiction of any Court in Westminster Hall." His search was not complete, as we have seen. "As no such attempt has ever been made, it would be a great novelty to allow this plea; and therefore it must be overruled." Thus, the Court finding no precedents, and counsel citing none, the plea is treated as too novel to support itself, and, accordingly, held to be of no value. And so a precedent is made, and the subject is no longer novel.

But Halfhide v. Fenning, ${ }^{5}$ decided but five years earlier, was in fact a precedent contra. There a bill is brought for an accounting between partners. The defendant pleads that by the articles of co-partnership all differences which might arise were to be referred to arbitration, and that the matter in dispute had not been so referred. The plea is held good. This ease was later than Lord Hardwicke's decision in Wellington v. Mackintosh, 2 Atk. 569, and expressly overrules it. It is later, also, than Kill v. Hollister, and, therefore, overrules Kill v. Hollister. Lord Kenyon here says: "There can be no doubt, but that parties entering into an agreement that all disputes shall be referred to arbitration, are bound by such agreement. The legislature has countenanced such agreements by the act of William 3, for facilitating the execution of them. . . Such references are very advantageous to the parties; as arbitrators are more competent to the settling of complicated accounts than the officers of conerts of law or equity." ${ }^{\circ}$ Was he right?

- Halfhide $v$. Fenning, 2 Brown's Chancery Cases 336 (1788).

- Italies ours. 
The reporter says in a footnote to this case: "This case is universally held to be against the law and practice of our Courts. It has always been held 'a singular case, and in direct opposition to Lord Hardwicke's docision in Wellington $v$. Mackintosh, 2 Atk. 569 ; besides that it has since been repeatedly over-ruled.'," But in 1844, as we shall see later, Lord Chancellor Sugden says: " "I think that Halfhide v. F'enning is still law."

Furthermore, the reporter in Mitchell $v$. Harris says it is now well settled "as an undoubted general rule, that a mere agreement to a reference does not estop a party from applying to a Court of Equity to determine his rights; but, where the submission to reference has been made a rule of a Court of Law (or either party has a right to make it such, Davis $v$. Getty, ${ }^{7}$ Sim. \& Stu. 414), it is, to say no more, extremely doubtful, whether even fraud will authorize Equity to interfere; Auriol v. Smith, Turn. 127; Dawson v. Sadler, 1 Sim. \& Stu. 541. . ."” Now, though Vynior's Case is nowhere directly cited in these cases, the decision of these days is directly traceable to its influence. We have seen how it affected the Court in Hide v. Petit, in Milne v. Gratrix (7 East. 608), and in King $v$. Joseph (5 Taunt. 452). Studying the footnote (Note 3) to Mitchell $v$. Harris, the reporter gives us the clew :

"Not only a parol submission to arbitration, but even a submission by deed, may be revoked, at any time before the award is made, although the submission should, after such revocation, be made a rule of Court; in such case, no contempt of Court is committed, which can be punishable by attachment; and, even if the submission had been made a rule of Court previously to its revocation, notwithstanding this revocation would be a contempt for which the

\footnotetext{
ours.

'Dimsdale v. Robertson, 2 Jones \& La Touche's Reports 58. Italic
} 
party might be attached; still, it seems, no award could be made, the specific execution of which could be enforced. The arbitrators, however, would do right in afterwards procecding to make their award; because the party, continuing in submission, will be entitled to his aetion for damages, on non-performance of the covenant by the other party to abide the award: or, if the bond contain an obligation to pay a certain penalty, in the nature of liquidated damages, although the obligee may still revoke his submission, he, of course, by so doing, forfeits the penalty of the bond. Milne $v$. Gratrix, 7 East, 611 ; King v. Joseph, 5 Taunt. 453."'

Though the reporter states that it follows as a neeessary corollary that "a bill for specific performance of an agreement to refer to arbitration, would not hold" (citing Gour. ley v. Duke of Somerset, 19 Ves. 431 and Agar v. Macklew, 2 Sim. \& Stu. 423) nevertheless "a. Court of Equity will not be disposed to listen to any interlocutory motion on behalf of a party who, without just grounds, refuses to abide by such agreement"' 8 (citing Waters v. Taylor, 15 Ves. $16^{9}$ ) ; "and it would be quite impossible," says he, "that a party, who, by revoking a submission which has been made a rule of Court, has been guilty of a contempt, should obtain special relief, in the same eause, from the Court whose order he has violated, contrary to his engagement. Supposing his revocation to be legally valid, it is not a case in which he has any reason to hope for the aid of Equity" (eiting Harcourt $v$. Ramsbottom, 1 Jac. \& Walk. 511).

In short, according to the reporter, you may punish, as for contempt of court, the man who revokes; you may deny him relief in a court of equity because he does not "come in with clean hands"; but if he brings suit in violation of his agreement, it is no plea in bar that by

Italics ours.

- See post, p. 161. 
so doing the Court will aid and abet him in his iniquity. Yet "The ethical impropriety of the ... revocation at sueh a stage in the proeeedings is obvious . . ." (T'oledo S. S. Co. v. Zenith Transp. Co., 184 Fed. Rep. 391, at p. 396 [1911] per Hollister, J.). ${ }^{10}$

Now, it is to be observed that none of the Chaneellors was wholly opposed to arbitration. What eoncerned them was giving the aid of Chaneery to either party, in spite of the arbitration, where "matter of equity" arose. This is made elear in the later ease (1807-8) of Waters $v$. Taylor, ${ }^{11}$ where Lord Eldon (in spite of his animadversions upon arbitration in Street $v$. Rigby ${ }^{12}$ ) says that where the parties have provided a forum for themselves it "shows their intention against the interference of any other jurisdietion, until they have tried the effeet of the speeial means, provided by themselves; and that eourse," says Lord Eldon, "which is familiar in the eommon ease of partnership, is more especially to be adopted, where the parties have themselves expressed that intention." Here there were partnership artieles for the management of the Italian Opera House. The articles contained provisions for arbitration. The plaintiff, one of the parties, brought suit in equity for injumetion, receivership, ete. The headnote of the case is: "Although an agreement to refer disputes to arbitration is, generally, no objection to a suit in a Court of Equity, yet upon the nature of the subjeet, the management of the Opera House, and the anxious provision of the parties for arbitration, the Court refused upon motion to interfere bcfore they had taken that course." ${ }^{13}$

${ }^{10}$ Here, at p. 396, the source of the revocability theory is given as Morse on Arbitration, p. 437, Vynior's Case. The Court says " the strictness of the rule grew out of the jealousy of the common-law judges in early times of their jurisdietion, and of their fear lest encroachments might be made upon it (Morse on Arbitration, 436), while in the modern view and practice the settlement of disputes by arbitration are encouraged by the courts. . .."

${ }^{11} 15$ Vesey Jr. 10.

${ }^{12}$ See post, p. 162.

${ }^{13}$ Italics ours. 
And in the report itself we read that the Lord Chancellor (Eldon) "suggested the absolute necessity, that these parties should go to arbitration;" 14 and gives as his reason that "it is much more wholesome, where the parties have contracted for this mode of settling their differences, and the point of dispute is one, which is expressly provided for, to let them try, whether they cannot so settle it; than that this Court should interpose upon this sort of summary application.",15 And so "The parties afterwards went to arbitration; and an award was made..." ${ }_{16}$

Lord Eldon expressly qualifies the decision of Lord Hardwicke in Wellington $v$. Mackintosh. He says: "Taking the general doctrine now to be according to Lord Hardwicke's opinion, which goes upon the principle, that this Court has powers of inquiry beyond those of an arbitrator, do any of those cases go the length of such a special, anxious, provision for arbitration as this ; ${ }^{17}$ applying to every case, in which a difference could arise; and stipulating expressly, not only that the arbitrators shall determine upon evidence, but that they shall be at liberty to use all other ways and means to enable them to decide, that they shall think fit: the parties evidently anxious to exclude this jurisdiction upon a subject, to which certainly it is very inadequate?" 17

In short, Lord Eldon did not find anything offensive to equity in parties agreeing to exclude the court of jurisdiction. He himself had said as counsel in Mitchell $v$. Marris that there was "no sense" in the holding in Kill $v$. Iollister that agreements of the parties "cannot oust the jurisdiction of the Court." And his argument is as sound today as it was then. The Court is not "ousted more than by a release of all right of action." And in

14 15 Vesey Jr. J0, at p. 12. Italics ours.

${ }^{15}$ Ibid., p. 19. Italies ours.

${ }^{10}$ Ibid., p. 20.

${ }^{17}$ Italies ours. 
Waters $v$. Taylor, he refers to the litigation of the parties as "calling down upon them an interposition, perhap:; not the most ruinous, but that cannot take place withont infinite mischief to all, who may have any interest in the subject," and so "I shall give them an opportunity to pause; and consider, whether they will press for my determination, or have their disputes determined by"-note the language here-" "that more wholesome mode, which they have themselves provided." 17

In Waters $v$. Taylor an application was made for a receivership and the Lord Chaneellor permitted the arbitrators to determine the very question of whether there should be a receiver, even permitting them to name a manager for the opera house, for he says: "Whatever may be the law of this Court as to the eapaeity of parties by stipulation to deprive themselves of the right to resort to a Court of Justice in the first instance, and taking the law to be, that a man eannot bind himself to forbear to come here, until an arbitration has been had, in almost every line of this deed of 1803, upon which the suit is instituted, the parties have expressed the greatest anxiety to keep out of Court; if they could in any manner arrange their disputes by arbitration." 18 And so he steadfastly refuses, even upon a third application and after the arbitrators had decided, to interpose the aid of Chaneery, saying, "if they will not settle their own interests, it is immaterial, whether the consequences shall be produced by their own acts or by mine." 19

Thus it was clearly Lord Eldon's opinion that these agreements wcre wholesome and should be enforeed, unless there were strong equitable grounds for intervention by a Court of Chancery, as where a discovery was required in aid of an accounting by arbitrators. As Sir

${ }^{17}$ Italies ours.

${ }^{18} 15$ Vesey Jr. 10, at p. 22. Italics ours.

${ }^{10}$ Ibid., p. 28. 
John Seott. in Halfhide v. Fenning (supra), he had tried to eonvince Lord Kenyon that the plea of an agreement to arbitrate differenees did not prechude a bill for a disrovery, though it might be a good plea to the relief. And Lord Kenyon in that ease, as we have seen, would not go with him.

But Lord Eldon had had a bitter experience with arbitration while at the Bar, as he tells us in his opinion in Street v. Rigby ${ }^{20}$ (1802). He had been eounsel in Price $v$. Williams, ${ }^{21}$ where, as he reports in Street $v$. Rigby, a bill for speeifie performance of an arbitration agreement was filed. Lord Thurlow refused speeifie performance, but referred the matter to a master whose report was very favorable to Lord Eldon's elient, "the result being, that a very small sum was due from him." Thereupon, "A vast number of exceptions were taken; and the Court felt that sort of diffieulty of dealing with the exceptions," and this "led to an arbitration; though at first the Court would not hear of it." And so, reports Eldon, "the party, who had not been able to establish any thing before the Master, in that mode gained several thousand pounds." "Then," says he, "the difficulty occurred about the power of this Court to review the decision of arbitrators; and in the end my elient fared much worse than he would have done before the Master." This experience raised in his mind"2 "considerable doubts, whether the eulogia upon the domestie forum of arbitrators are well founded" and that case and others led him "to adopt a rule never to advise an arbitration afterwards." ${ }_{23}$ Yet, as we have seen, five years later, in Waters $v$. Taylor, he had already overeome the sting of disappointment in Price $v$. Williams and was broad-minded enough to apply rigorously to the

${ }^{20} 6$ Vesey Jr. 814, at p. 817 .

${ }^{21} 3$ Bro. C. C. 163; 1 Vesey Jr. 365. This report does not give the earlier history of the case.

${ }^{2} 6$ Vesey Jr. 814, at p. 818 .

${ }^{23}$ Ibid., p. 819. 
parties the agreement to arbitrate which they had made, though it meant, in effeet, an actual determination of the eourt's jurisdiction.

If we make a reasonable allowance for the disappointment with some arbitrations which Lord Eldon shared with others at the Bar, we shall find in the decisions of the chancellors of his day no evidenee of real hostility to arbitration agreements as such, and no determination to hold them void as against public policy. These judges were concerned only with preserving that jurisdiction of the equity courts which would relieve the parties of any situation that, in spite of the written word, was "against conscienee." Lord Eldon concedes in Street $v$. Rigby that his own argument in Halfhide $v$. Fenning was unsound for the reason that when the parties agree to arbitrate they mean "this, if any thing;" that they "will not harass themselves by going to Courts of Justice; but will state to each other what is in dispute, and refer that to arbitrators; and entering into such a covenant they must be taken to mean, that they will be content with a decision upon such diseovery as arbitrators can eompel, without subjecting each other to the neeessity for either to be examined upon oath, before arbitrators, who cannot examine them upon oath." 24 Aeeordingly, he says, "they choose therefore that forum exclusive of the jurisdiction of the country to all intents and purposes; meaning, that arbitrators shall from beginning to end do that, which they are enabled to do, viz., to decide between them as well as they can." 25 And if they break their agreement, a suit is justified, in which, it is true, they would recover only nominal damages, just as mueh if they file a bill for discovery as if they file a bill for discovery and relief. Accordingly, having demolished his whole argument in Malfhide v. Fenning, he then says that it is not surprising "that

${ }^{24}$ Vesey Jr. 814, at p. 819.

${ }^{25}$ Italies ours. 
Lord Kenyon should take it, that the Counsel (Lord Eldon) thought, if not upon that, it (the plea) could not be supported." "But," says he, "if the distinction cannot be maintained between a bill for discovery only and for both discovery and relief, it must be said, they are bound to go first before the arbitrators; and the party must be brought there; and must refer: the parties to be examined upon honour ; for they eannot upon oath." 26 It is true this situation does not quite appeal to the Lord Chancellor's sense of equity, for if the parties are always to wait until after an award before applying to equity for relief, he observes that they may lose all opportunity for relief, and if they apply for relief ancillary to the arbitration, he recalls "passages, in which Courts of Justice, however full of eulogia upon these domestie forums, have recollected their own dignity suffieiently to say, they would not be ancillary to those forums." And so he says: "I do not enter into the question of the effeet at law of a covenant to forbear to sue." Of course not; a release is such a covenant. At law it was a full bar. But equity, upon familiar grounds, could relieve the parties. "But, supposing it good, in strict law it cannot be maintained, that having covenanted to refer the party has covenanted to forbear to sue; and if not, he has only left himself open to an action for damages, if he does not refer; which the suit does not prevent, if thought advisable." ${ }_{26}$ And now comes the elear explanation for the point of view of a great Equity Judge: "It would be very strong to say, that, where the legal remedy they have provided for themselves is utterly incompetent to justice, this Court is precluded from granting its ordinary remedy, by a covenant, which does not in terms express an undertaking not to resort to this Court: and must hold that doctrine upon a plea; in that shape permitting the Defendant to have in substance a specific performance, which would have ${ }_{20}^{20}$ Vesey Jr. 814, at p. 820 . 
been refused to him as a Plaintiff." 27 In other words, it is the chief business of equity to relieve parties from situations in which they find themselves helpless at law. Where a deed, a release, or a contract lias been secured by fraud, by mistake, by taking nudue advantage of one of the parties, equity is swift to the reseue; why not in the ease of such eovenants as these? The initial error arises from the failure to follow the deeision of Jeffreys, to which no one calls attention in the days of Loughborough, Hardwieke, Kenyon and Eldon; and the refusal to aid in the enforcement of agreements to arbitrate. It was not, as at first the judges feared, impracticable. Five years later Lord Eldon did this very thing. ${ }^{28}$ Then he was restrained by no fear that sustaining the plea gave the defendant relief which he could not secure in an aetion for specific performance. ${ }^{29}$

In Street $v$. Rigby, as in Mitchell $v$. Harris, Lord Eldon insists upon the jurisdiction of equity to protect the parties even against their own covenant, just as in Waters $v$. Taylor, he enforees their covenant for them. He says in Street $v$. Rigby "that no instanee is to be found of a decree for speeific performance of an agreement to name arbitrators; or that any diseussion upon it has taken place in experience for the last twenty-five years." 30 But we submit that the seareh for preeedents was not complete, and that in any event, five years later, in Waters $v$. Taylor, the Chancellor himself made sueh a precedent. In equity, he compelled the parties to carry ont their agreement to arbitrate.

From all of whieh we may now conclude that the Chancellors of these days had no intention of avoiding the legal

${ }^{27}$ Ibid., p. 821. Italics ours.

${ }^{29}$ Waters $v$. Taylor, 15 Ves. Jr. 10.

${ }^{29}$ And under the spur of Parliament, the courts in 1892 do find a way to enforce specific performance of such agreements. Sce post, pp. 212-213.

${ }^{80} 6$ Yes. Jr. 814 , at p. 817. 
effeet of agreements to arbitrate-they were coneerned only with the problems of equitable relief in such cases. ${ }^{31}$

Lord Kenyon in Thompson v. Charnock, ${ }^{32}$ in 1799 , does himself a grave injustice by saying: "It is not neeessary now to say how this point ought to be determined if it were res integra, it having been decided again and again that an agreement to refer all matters in difference to arbitration is not sufficient to oust the Courts of Law or Equity of their jurisdiction." But a still greater injustiee was done to Lord Kenyon in assuming in Thompson $v$. Chamock he had reversed his deeision in Halfhide v. Fen$\operatorname{ling} .^{33}$

Later than Thompson $v$. Charnock (1799), Mitchell $v$. Harris (1793), Street $v$. Rigby (1802) and Waters v. Tay-

${ }^{31}$ The English judges and the Scotch judges were not in accord upon this subject. See diseussion by Bell, Law of Arbitration (2nd E(l.), pp. 24, 267, 268, and discussion by Lord Monereiff in Brakinrig r. Menzies, 4 Sess. Cases, 2nd Series, 274, at p. 282 et seq., also remarks by Lord Campbell in Mackenzie v. Girvan, 2 Bell's App. 43, at p. 55, wherein his Lordship said that to him it seemed "the practice of Scotland is much more convenient than the practice here" and that the English practice "has produced very great inconvenience." The Scotch rule was, as stated by Moncreiff in Brakinrig v. Menzies (p. 283) :

"All the authorities agree that a submission to arbiters is a contract by which the parties commit to the entire and exclusive cognizance of the arbiter or arbiters named the whole matter sub. mitted, and bind themselves to abide by his or their decision in all things.", And this comprehended "the decision in law as well as in fact.",

This rule Lord Campbell regarded as a "much more reasonable", rule than the practice in England, whereby if it appears upon the face of the award, or in the papers referred to in the award, that the arbitrator has mistaken the law, the Court had jurisdiction over the award and will set it aside.

"That has producel so much inconvenience in this country,", said Lorl Campbell, "that for a number of years past in Westminster Hall, they have said that they would not at all review what the arbitrator had done, if it was referred to a barrister-at-law-a gentleman in the law; but that whatever he decided, whether right or wrong, should be final between the parties.' (Mackenzie $v$. Girvan, supra, at p. 55.)

a2 8 T. R. 139 , at p. 140 .

${ }^{33}$ See Lord Chancellor Sugden's remark in Dimsdale v. Robcrtson (1844) 2 Jones \& La 'Touche's Reports 58, post. 
lor (1807-8) appears Harcourt 2 . Ramsbottom. ${ }^{34}$ This case comes before Lord Eldon in 1820. It will bear eareful study.

Here were articles of arbitration between bankers. A suit had been brought and a receiver appointed. Both parties then agreed to arbitrate and the agreement provided for the manner of appointing the arbitrators. The appointment of the arbitrators was confirmed by order of the court. Thereafter the plaintiff revoked the submission, but the arbitrator went on and made the award. Then the plaintiff brought a bill in equity to set aside the award. And his counsel contended that "The authority of an arbitrator is always revocable till the award is made; and if one party revoles it, the only remedy of the other is by an action on the bond or covenant." ${ }_{35} \mathrm{He}$, too, relies upon King v. Joseph, ${ }^{36}$ and Milne $v$. Gratrix, ${ }^{37}$ which, it will be recalled, are direct descendants of Coke's dictum in Vynior's Case. ${ }^{33}$ To all of which Lord Eldon replies: "It is said, the award is not good because the authority was revoked: my answer is, that if it is revoked at law, I could not have considered it as revokcd in equity, whether it was made a rule of Court or not." 39 He says to the plaintiff: "If the award was not enforced, this Court would leave the parties to deal with the matter at law; and if at law you can restrain them from selling these estates, do it; but you have no equity to come here." ${ }_{39}$

And even as to the rule at law he is not quite certain, for he says: "I am not saying it (the revocation) is good at law, but I agree entirely that it is bad in equity, under

34 1 Jacob \& Walker's Chancery Reports 505 (First American, from the first London edition).

${ }^{35}$ Ibid., p. 507. Italies ours.

${ }^{30} 5$ Taunt. 452.

${ }^{37} 7$ East 608.

${ }^{38}$ See supra, p. 157.

${ }^{39} 1$ Jacob \& Walker's Chancery Reports 505, at p. 511. Italics ours. 
these circumstances." ${ }_{40}$ So, whatever its effeet at law, this great judge treats the revocation of a submission, except where equitable grounds for it are proved, as bad in equity. And he will not permit the parties to argue that the award is ineffective. "Because one party says it is revoked, then, although it is matter of justice to the other party, yet the arbitrator is not to hear him on the other parts of his case; but is to say at once, this party will not let me go on. . . . It is impossible to maintain that." ${ }_{41}$

Thus Milne v. Gratrix (1806), King v. Joseph (1814), Aston v. George (1819) and Hide v. Petit (1670) are set aside. Yet this later ease (1820) is treated by the reporters of the day as hardly deserving of more than passing notice and, as we shall see, is rarely, if ever, referred to in later argument.

In Chancery, in Lord Eldon's day (1823), where it is one of the terms of an agreement to refer disputes to arbitration that the submission shall be made a Rule of Court of Common Pleas if either party require it, the Court refuses to relieve a party from an award even though the submission has not been made a rule of the Court of Common Pleas within the statutory period. The Vice-Chaneellor (Sir John Leach) says: "I eannot consider that it was the intention of the Legislature to leave it to a party who meant to complain of the award to escape, at his pleasure, from the provisions of the statute."

In 1838, the Vice-Chaneellor (Lord Shadwell) in Pope $v$. Lord Duncannon ${ }^{42}$ refused to restrain the defendants from acting upon an award where the plaintiff had revoked the submission before the arbitrators had made an award. The Vice-Chaneellor expressly adopts Lord Eldon's reasoning in Harcourt $v$. Ramsbottom. "I say," said he, "that a

\footnotetext{
1 Jacob \& Walker's Chancery Reports 505, at p. 612 . Italieg ours.

"Ibid. Italies ours.

49 Sim. 177, at p. 179, 180. Italies ours.
} 


\section{"OUSTING THE COUR'TS OF JURISDICTION" 169}

Plaintiff is not at liberty to ask the aid of a Court of Equity in respect of an act done by him against good faith" and as there was nothing to show that the revocation was based upon "any just or reasonable grounds," in other words, "matter of equity," "I am bound to conclude that the revocation was a wanton and capricions exercise of authority. ..."

We now come, in 1844 , to Dimsdale v. Robertson, ${ }^{43}$ where Lord Chancellor Sugden follows and adopts Lord Eldon's statements in Waters $v$. Taylor, wherein he says, by their agreement "the parties .. . anxiously provided for the reference to arbitration ..." and "Lord Eldon there, upon an interlocutory application, drove the parties to a reference." 44 After reviewing all the cases-including Mitchell $v$. Harris, Wellington $v$. Mackintosh, Thompson $v$. Charnock and Street v. Rigby, the Lord Chancellor says:

"Upon the whole, therefore, I think that Halfhide $v$. Fenning is still law." 45

He says that Lord Kenyon in Thompson $v$. Charnock was misunderstood. "I am not aware," says he, "of any case in which Lord Kenyon doubted his own decision [Halfhide $v$. Fenning]." "There is no report of any decision of Lord Thurlow's impeaching Lord Kenyon's." 46 Accordingly, the Chancellor refuses to aid the plaintiff in withdrawing a case from arbitration.

432 Jones \& La Touche's Reports 58.

${ }^{44}$ Ibid., p. 93. Italics ours.

st Ibid., p. 92. Italics ours.

so Ibid., p. 92 . 


\section{CHAPTER XIV}

THE ERROR IS CORRECTED: SCOTT V. AVERY (1855)

WE may now proceed directly to the eonsideration of Scott $v$. Avery, ${ }^{1}$ decided in 1855 in the House of Lords, where, after much debate, the rule of Vynior's Case and Kill $v$. Hollister is reversed. Here it is held that parties may covenant "that no right of action shall acerue till a third person has deeided on any difference that may arise between himself and the other party to the covenant." Atherton and Pollock argue that this agreement "is in itself illegal, as ousting the jurisdiction of the courts of law" and cite Kill $v$. Hollister, Wellington v. Maekintosh, Thompson v. Charnock, Street $v$. Rigby and Waters $v$. Taylor.

The judges consider all these authorities, as well as Halfhide v. Fenning and Dimsdale v. Robertson. Baron Martin and Lord Coleridge are for the rule stated in Thompson v. Charnock and Kill v. Hollister. Lord Chancellor Cranworth and Lord Campbell are for the broader rule in Halfhide v. Fenning and Waters v. Taylor. Baron Martin says:

"The true ground I believe to be, that a prospective agreement not to have recourse to the courts of law or equity of the country in respect of future causes of action to arise, is against the liberty of the law, which secures to every one the right of submitting to the courts any matters in respect of which he elaims redress." 2

But it is not the liberty of the individual to resort to the courts in spite of his agreement to the eontrary, for

15 H. L. C. 811; 25 L. I. (Exch.) 308.

"Ilid., p. 83,0 . 
the courts will decline to lend him their aid if he has waived his rights or in good faith released the other party from all claims against him. Mr. Justice Crompton says very logieally, it seems to us, that "the proceeding to be gone through under the agreement in question was an arbitration of a strictly judicial nature, in whieh the arbitrators were to proceed judicially." ${ }^{3}$ Aecordingly, he finds that this covenant does, in faet "onst the eourt of jurisdiction." But he says that "It is a legal ineident to every eontraet that the parties should have a right to resort to a court of law for the settlement of their disputes; and a stipulation to the eontrary is void, as being repugnant to the rest of the eontract." 4

Contrary to the decisions of Lord Eldon, Lord Sugden and Lord Kenyon, the rule is now re-dressed and put forth by Baron Martin and Lord Coleridge as a rule of public poliey. Now it is no longer a matter merely of appropriate relief, but such provisions are absolutely void. Of eourse, if they are void, they are revocable-thus once more Lord Coke's dietum comes to reign over England.

But here we are referred to a new souree of authorityagain from Coke. Baron Parke, in the Court of Exehequer, had quoted a passage from Coke Littleton: " "If a man make a lease for life, and by deed grant that if any waste or destruction be donc that it shall be redressed by neighbours and not by suit or plea-notwithstanding, an action of waste shall lie, for the place wasted eannot be recovered without a plea." But "The case," says Mr. Justiee Cresswell in the House of Lords, ${ }^{6}$ " is not to be found in the Year Book, $3 E d w$. 3, referred to, but is in Fitzherbert's Abridgment, 'Waste,' Placitum 5, and the whole of it is given in Coke Littieton." The learned Baron had

- Ibid., p. 834.

Ibid., p. 835.

- 8 Exch. Rep. 494.

- 5 H. L. C. 811 , at p. 837 . 
not consulted Statham or Bracton, nor found the cases we have cited from Fitzherbert, nor referred to the cases in Bracton's Note Book. Moreover, as Mr. Justice Cresswell very properly observed in criticism of Baron Parke's reference:- "It seems that this decision proceeded on the ground that the neighbours could not redress the wrong done; that it could only be done by plea; therefore, notwithstanding the deed, an action of waste would lie. There is not a word leading to the supposition that an action would have been maintainable, if neighbours could have given the appropriate redress; or that it might not have been granted by decd, that if a dispute arose about uaste, neighbors should say whether there had been waste or not." " Yet without further examination or consideration of other and older precedents, this quotation from Coke was "considered to have established that parties cannot by agreement oust the jurisdiction of the Courts of the realm.",

Upon this basis, the plaintiff had been permitted to recover in the Court of Exclequer, which at that time consisted of Barons Parke, Alderson, Platt, and Martin. ${ }^{8}$ On appeal, however, the Court of Exchequer Chamber reversed the judgment, though Coleridge, J., conceded 9 " that any agreement which is to prevent the suffering party from coming into a Court of law, or, in other words, which ousts the Courts of their jurisdiction, cannot be supported." Upon appeal to the House of Lords, the defendant's plea is sustained, the agreement to arbitrate is held to bar the suit in equity, the plaintiff is not permitted to revoke.-In short, the doctrine of Halfhide v. Fenning, Waters $v$. Taylor and Harcourt $v$. Ramsbottom prevails.

Mr. Justice Coleridge says, however: "The prineiple of

${ }^{7} 5$ H. L. C. 811 , at p. 837 . Italies ours.

8 Exch. Rep. 487.

'Ibid., p. 500. 
law which is relied on by the Plaintiff in Error is agreed on. The difference between the parties is upon the question whether it governs the present case. . . If two parties enter into a contract, for the breach of whieh in any particular an action lies, they eannot make it a binding term, that in such event 110 action shall be maintainable, but that the only remedy shall be by referenee to arbitration. Whether this rests on a satisfactory principle or not may well be questioned; but it has been so long settled, that it cannot be disturbed." ${ }^{10}$ A more thorongh examination of the earlier cases would have couvinced the learned judge that no such proposition had been settled and that, indeed, there was good reason why it should have been questioned.

Again, Lord Coleridge says: "The courts will not enforce or sanction an agreement which deprives the subject of that recourse to their jurisdietion, which has been considered a right inalienable even by the concurrent will of the parties." But agreements to submit differenees to arbitration are not intended to deprive the subject of recourse to the jurisdiction of the courts. Indeed, the remedy for enforeement of an award is to sue in the courts upon the award, or, if a bond is given, to sue on the bond. All the arbitrators do is to determine what is owing from one party to the other. This does not make the arbitration unenforcible in eourts of law or equity-save as the courts themselves have made it so; nor -where matter of equity is involved, does it preclude reeourse to equity. What the party seeks in the arbitration is a determination of what is due, by the cheapest and most expeditious process. This surely is not against publie policy. And an agreement determining the process or selecting the machinery is like any other kind of agreement, one that the courts should enforee, unless it be against public policy ${ }^{10} 5$ H. L. C. 811 , at p. 841 . Italics ours. 
just as Lord Eldon did enforce it in Waters $v$. Taylor and in Harcourt $v$. Ramsbottom.

Mr. Justice Coleridge practically concedes this when he says:

"But nothing prevents parties from ascertaining and constituting as they please the cause of action which is to become the subject-matter of decision by the courts. Covenanting parties may agree that in case of an alleged breach the damages to be recovered shall be a sum fixed, or a sum to be ascertained by $A$. $B$., or by arbitrators to be chosen in such or such a manner; and until this be done, or the non-feasance be satisfactorily accounted for, that no action shall be maintainable for the breach." 11 And "This position," he says, "has not been questioned in the argument before the IIouse; nor was it, I think, in the Court below:" 12 In this, he was in error; for the plaintiff's counsel argued and argued logically - so we believe-and Baron Parke and his colleagues agreed with him, that to leave arbitrators to determine what is due from $A$ to $B$ is to permit them to determine the entire controversy, and this, in a very practical sense, ousts the court of jurisdiction. My Lord Coleridge was not satisfied that arbitration agreements should not be upheld, but he felt constrained, for want, shall we say, of better guidance, to treat the law as so settled. But he whittled it to the vanishing point; for every covenant to submit to arbitration is in truth and in fact a covenant not to resort to the courts to cnforec one's rights until arbitrators have determined those rights.

And so Mr. Justice Coleridge is forced to conclude: "It is true that in arriving at the sum to be sued for, the committee, or the arbitrators, may have to consider the nature of the claim, and the proofs of it; but, so in settling

115 H. L. C. 811, at p. 841. Italies ours.

${ }^{12}$ But see his observations thirty-six years later (1892) in Trainor r. Phoenix Fire Assurance Co., 65 I. 'T. 825 (post, pp. 210-211). 
the amount to be recovered by a builder or a railway contractor, the architect or engineer, or whoever may be the preliminary referee agreed on for the purpose, must examine and decide that which may really be the very point in dispute between the parties, namely, the quantity or the goodness of the work, or the quality of materials used; yet no one objects that on this account the stipulation for submission to this previous inquiry is void as ousting the jurisdiction of the courts." ${ }^{13}$ And why is the learned Justice so keen to draw this nice distinction? He tells us: "I certainly am not disposed to extend the operation of a rule which appears to me to have been founded on very narrow grounds, directly contrary to the spirit of later times, which leaves parties at full liberty to refer their disputes at pleasure to public or private tribunals." ${ }_{13}$ The spirit of 1856 was disposed to leave "parties at full liberty to refer their disputes at pleasure to public or private tribunals." But what becomes of the doctrine of revocability of a submission or agreement to arbitrate, or of its being void as against public policy? True it is, that after Scott $v$. Avery, and down to 1892, English courts attempted to apply the subtle distinction of Mr. Justice Coleridge between "access to the courts of law" and "a condition precedent to appeal to them"-but all that was ever necessary in order to apply the true doctrine was to follow Lord Eldon, in Waters $v$. Taylor, and Lord Kenyon in Halfhide v. Fenning, and Lord Sugden in Dimsdale v. Robertson,-and, with reverence for their antiquity, the judges of Bracton's time-to treat the covenant to arbitrate as a plea in bar, but to leave the parties free to seek relief from the audard in accordance with principles of Equity.

In truth, an agreement to arbitrate is a release, conditioned upon the determination of an event subsequent.

Lord Chancellor Cranworth in the prevailing opinion, in the House of Lords, asserts that the general policy of

15 H. L. C. 811 , at p. 843 . Italics ours. 
the law is "that parties cannot enter into a contract which gives rise to a right of action for the breach of it, and then withdraw such a case from the jurisdiction of the ordinary tribunals. But surely," he continues, "there can be no principle or policy of the law which prevents parties from entering into such a contract as that no breach shall occur until after a reference has been made to arbitration." ${ }^{14}$ He finds that "the meaning of the parties" in the case at bar was "that the sum to be recovered should be only such a sum as, if not agreed upon in the first instance between the committee and the suffering member, should be decided by arbitration, and that the sum so ascertained by arbitration, and no other, should be the sum to be recovered." 15 "And," remarks he, "if that was their meaning, the circumstance that they have not stated that meaning in the clearest terms, or in the most artistic form, is a matter utterly unimportant." 15

Now we contend that this is the intendment of the parties in every arbitration clause. There is to be no "ousting the courts of jurisdiction" to grant relief, equitable or otherwise, but there is to be a determination of what is due from one to the other.

My Lord Campbell found the contract in Scott v. Avery "as clear as the English language could make it, that no action should be brought against the insurers until the arbitrators had disposed of any dispute that might arise between them." "16 "That being the intention of the parties," he asks. "is the contract illegal?" He finds "an express undertaking that no action shall be brought until the arbitrators have decided, and there is abundant consideration for that in the mutual contract into which the parties have entered; therefore," says he, "unless there is some illegality in the contract, the Courts are bound to

155 H. L. C. 811 , at p. 817 . Italies ours.

${ }^{15}$ Ibid., p. 849.

"Ibid., p. 851 . 
give it effect." "1i He finds "no statute against such a contract"- "then, on what ground is it to be declared illegal?" he asks. "It is contended," he says, "that it is contrary to public policy" but "that is rather a dangerous ground to go upon" and upon this point he refers the Lords to a very important case then but lately decided; ${ }^{19}$ "but what pretence ean there be for saying that there is anything contrary to publie policy in allowing parties to contract, that they shall not be liable to any action until their liability has been ascertained by a domestic and private tribunal, upon which they themselves agree?" ${ }_{17}$

Now, it will be recalled that the other judges had said that such a covenant deprived the individual of his liberty at all times to resort to the courts. But Lord Campbell says, we think with truth: "It seems to me that it u'ould be a most inexpedient encroachment upon the liberty of the subject if he were not allowed to enter into such a contract. ... Is there anything contrary to public policy in saying that the (Insurance) Company shall not be harassed by actions, the costs of which might be ruinous, but that any dispute that arises shall be referred to a domestic tribunal, which may speedily and economically determine the dispute?" ${ }_{19}$ So it seems to us. Like Lord Campbell, we do not see "the slightest ill consequences that ean flow from such an agreement;" on the eontrary, we see "great advantage that may arise from it," and say with him: "Public policy, therefore, seems ... to require that effect should be given to the contract." 20

He distinguishes Thompson $v$. Charnock, it is true, beeause in that case there was simply a "clause or covenant to refer to arbitration," which went no further; but he finds a more recent precedent in point in the ease of

${ }^{17}$ Ibid., p. 852. Italies ours.

${ }^{13}$ Egerton $\tau$. Brownlow, 4 H. L. C. 1.

${ }^{16} 5$ H. L. C. 811 , at p. 852,853 . Italies ours.

${ }^{20}$ Ibid., p. 853. Italies ours. 
Brown $v$. Overbury, ${ }^{21}$ where, as a condition of holding a race, any dispute was to be referred to the stewards. In the latter case, the trial judge decided and was upheld unanimously by the Court of Exchequer, that "even if the horse could clearly be shown to have won, the action had not accrued till the arbitrators, the stewards, had determined;" 22 and so there the plaintiff was non-suited. It is noteworthy that my Lord Campbell could not distinguish these two cases in principle. "Substitute stewards for arbitrators," he says, "and it is the same question, whether it is a contract of insurance, or a contract upon a horserace, which by Act of Parliament is legal." ${ }^{23}$ And so Lord Chancellor Cranwortl, Lord Campbell, and Lord Brougham all coneur in Judgment for the Defendant. ${ }^{24}$

Lord Campbell's views were most favorable to arbitration. In Mackenzie v. Girvan ${ }^{25}$ in 1843 he had lamented the "inconvenient" and "expensive" results of the administration of the rule in England as compared with that of Scotland. He thought then that it was highly desirable that parties should be left free to "select a judge on whom they place confidence as to his legal qualifications, and as to his eapacity to decide facts," and that in so doing "they think that he will dispose of the matter more satisfactorily than the regular tribunals of the country, more cconomically perhaps, and more expeditiously,-and that there may be no appeal to the Inner House, or to the House of Lords, they therefore," says he, "select him as their judge, and his judgment is to be final." As we have scen, the Scotch judges always were elear "that a submission to arbiters is a contract by which the parties commit to the entire and exclusive cognizance of the arbiter

211 Exch. Rep. 715.

25 H. L. C. 811, at p. 855. Italies ours.

Ibid., p. 855 .

"Scott v. Avery, 5 H. L. C. 811, 25 I. J. (Exch.) 308.

${ }^{25} 2$ Bell's App. Cases 43, at p. 55. 
or arbiters named the whole matter submitted, and bind themselves to abide by his or their decision in all things" -and this comprehended, to their mind, "the decision in law as well as in fact." 26

${ }^{*}$ Per Moncreiff, Lord, in Brakinrig v. Menzies (H. L.) 4 Sess. Cases, 2nd Series, 274, at p. 283. Italics ours. 


\section{CHAPTER XV}

THE TRUE INTERPRETATION OF SCOTT V. AVERY (1855́ TO 1894)

Ioro Chancellor Cranworth, who presided at the trial of Scott v. Avery in the House of Lords, and who, as Lord Coleridge later said, "was no mean authority," " presided the same year in the House of Lords in Drew v. Drew, ${ }^{2}$ deeided shortly prior to Scott v. Avery. He then stated his understanding of the law of England clearly and forcibly. His Lordship observed that, prior to 3 and 4 William IV. c. 42 , "if parties submitted a matter for arbitration to a private tribunal to be decided by a sclected person, either of them might at any time, without assigning any ground, revoke that Submission. That was an inconvenient, and, I think I may be allowed to say, an irrational state of the lau," said he. . . . "I say that was an absurd state of the law, which has since been rectified, and now the law may be represented as being that neither party to a submission can stop an arbitration pending its proceedings without first obtaining the sanction of some Court of Westminster Mall, or of one of the Judges, for so doing." 3

In the same year (1855) in Northampton Gas-Light Company v. Parnell, 4 (Common Pleas) Hilary Term, Maule, J., says: "The old rule upon which it was held that the power of an arbitrator was revocable, was, that a power not coupled with an interest, was revoeable,-revocable by the authority which created it. From that rule it was in-

${ }^{1}$ See post, p. 211.

${ }^{2}$ Drew v. Drew, 2 Macq. Reports (H. of L.) 1, March, 1855.

Ibid., pp. 3, 4. Italies ours.

15 Common Bench Reports 630. 
ferred-erroneously, as I think-that one of the parties to a submission might revoke without the other. It seems to me that that was allowing one man to affect the interest of another. But it uas an inveterate error." ${ }_{5}$ This reasoning was followed not only in the House of Lords and at Common Pleas, but in Qucen's Bench, in the Court of Exchequer, and in other courts in England.

In 1856, in Queen's Bench, in Russell v. Pellegrini, ${ }^{8}$ it appeared that a charter party for a ship provided that "Should any difference of opinion arise between the parties to this contract, either in principle or detail, the same" should be referred to arbitration. The charterer claimed from the ship owner damages for an alleged breach of an implied warrant of seaworthiness and sought to secure a reference. The ship owner refused. Then the charterer commenced an action. The monthly hire coming due in the meantime, the ship owner sued. The Court stays the ship owner's suit, being satisfied that the charterer "had always been desirous to refer all matters."

The clause itself is important. "Should any difference of opinion arise between the parties to this contract, either in principle or detail, the same shall be referred for arbitration to two persons, one to be chosen by each contracting party, with power to call in a third person as referee, the decision of a majority of whom shall be final and binding." It will be observed that there are no words as to "condition precedent to suit," etc. The clause is the plain "general arbitration" clause. It is Lord Campbell who speaks: "Somehow the Courts of law had in former times acquired a horror of arbitration; and it was even doubted if a clause for a general reference of prospective disputes was legal. I never could imagine for what reason parties should not be permitted to bind themselves to settle their disputes in any manner on which they agreed.

'Ibid., p. 645. Italics ours.

'6 Ellis \& Blackburn 1020. 
The decision in Scott $v$. Avery, that an agreement that there should be a reference before the party should be at liberty to sue might be so made as to be binding, was a very wholesome decision." ; Again: "I think that both the demand for the monthly hire, and the cross claim for damages, arose out of the contract, and are matters referrible within this agreement." 8

In these several cases we have direct confirmation by both Lord Cranworth and Lord Campbell of the legal effect of Scott v. Avery. In Russell v. Pellegrini Coleridge and Wightman concur with Campbell.

Again, Baron Martin, who differed with Lord Cranworth and Lord Campbell in Scott $v$. Avery, says himself in 1859: "Scott v. Avery has overruled all the previous decisions on the subject." "Lord Campbell certainly held that an agrement to refer any dispute to arbitration is binding, and that no action can be maintained until after an adjudication by the arbitrator." And "I think that the decision in Scott $v$. Avery cannot be upheld unless the judgment of Lord Campbcll is right." 10

In 1859 an appeal was taken to the Court of Exchequer, in Wickham $v$. Harding. ${ }^{11}$ A contract by which defendant engaged plaintiff to manage his business contains the following arbitration clause: "That in case any dispute or question shall arise between the parties in respect of the carrying on of the business, or otherwise, or any matters comnected with or in relation to this deed, the same shall be decided by two persons. ..." The court stays the action, and in so doing, upholds the clause. Pollock, C. B., says: "The parties expressly agreed that should any dispute arise relating to the defendant, it should be re-

: 6 Ellis \& Blackburn 1020, at pp. 1025, 1026. Italics ours.

${ }^{8}$ Ibid., p. 1027.

"Horton v. Sayer, 4 Hurlstone \& Norman 643, at p. 650.

10 Italics ours. See post, p. 186.

1129 L. .J. (Exch.) 215. 
ferred to arbitration. Sometimes parties would not cnter into contracts not containing such a clause." Nartin, B., sees strong reason for referring to arbitration, "for there are no cases which juries are more apt to decide against the evidence than cases of this kind, in which it is said the defendant's character is concerned." And Baron Bramwell remarks: "But clearly this action must involve matters of account, and they are very unfit for a jury. Moreover, a bargain is a bargain, and the parties ought to abide by it, unless a clear reason appears for their not doing so." 12

Seligmann $v$. Le Boutillier ${ }^{13}$ was considered in the Court of Common Pleas in 1866. An arbitration clause in a charter party is reviewed. "Should any dispute arise between the owners and the charterers, the matters in dispute shall be referred to three persons at Liverpool, one to be appointed by each of the parties hereto, and the third by the two so chosen; their decision, or any two of them, shall be final; and, for the purpose of enforcing any award, this agreement may be made a rule of court." It should be noted, that the rule of court applied for is "for the purpose of enforcing any award." Obviously, if either party conld revoke at will, the failure of one to agree upon an arbitrator would enable suit to be brought by either. But the Court follows Russell v. Pelligrini ${ }^{14}$ and Wickham v. Harding. ${ }^{15}$

At this time, none of the judges refers to Vynior's Case, Hide v. Petit, Kill v. Hollister, Milne v. Gratrix, King $v$. Joseph or Aston v. George, and it would seem as though the original judicial error were judicially corrected. However, says Maitland, "It is perhaps the main fault of 'judge-made law' (to use Bentham's phrase) that

12 Italies ours.

${ }^{13}$ L. R. 1 C. P. 681. Italies ours.

${ }^{14} 6$ E. \& B. 1020,26 L. J. (Q. B.) 75.

1528 L. J. (Exch.) 215. 
its destructive work can never be cleanly done. Of all vitality, and therefore of all patent harmfulness, the old rule ean be deprived, but the moribund husk must remain in the system doing latent mischief." 16 'Though my Lord Coke's dictum regarding the revocability of a power given to arbitrator's is clestroyed by England's highest appellate tribunal, and though, seemingly, it is torn up from the roots by the Lord Chancellor and his eolleagues, its "moribund husk" remains "in the system doing latent mischief." Two and a half eenturies of indulgence in error have left their firm impress of habit in the thinking processes of able and learned men. "Absurd," "an irrational state of the law," Lord Cranworth thought; "inveterate error," Maule pereeived.

Inveterate indeed. Like the eat, it has nine lives; dropped out of the window, it comes in the back door. For in the next quarter of a century, we shall see Scott $v$. Avery "followed," "'interpreted," "'modified," sometimes a revered precedent, sometimes neglected; but in 1894 the sturdy spirit of the Common Law leads it again into its rightful estate.

In 1861, in Braunstein $v$. Accidental Death Ins. Co. ${ }^{17}$ the following provision of a policy was considered: ". . . in case of difference of opinion as to the amount of compensation payable in any case, the question should be referred to the arbitration of a person to be named by the seeretary for the time being of the Master of the Rolls, and all expenses and costs should be subject to the deeision of suel arbitrator, and the award made on such arbitration was to be taken as a final settlement of the question, and might be made a rule of Court." 18 Crompton, J., speaking for the Court, Blackburn, J., coneurring,

\footnotetext{
${ }^{18}$ Enegclopgedia Britamica, 11th ed., Vol. 9, p. 606, art. "English Law," by F. W. Maitland.

${ }^{17} 1$ Best \& Smith 782.

${ }^{28}$ Ibid., p. 786.
} 
held that "this case comes within the principle of Scott v. Avery" and added: "I think we may construe the having the amount determined by a third party as part of the cause of action; and a great Judge, Mr. Justice Maule, was of this opinion." 10

Commenting on this case, Judge Allen of the New York Court of Appeals ${ }^{20}$ says: "In Braunstcin's case the policy did not, in terms, declare that the award of arbitrators should be a condition precedent to the bringing of an action. The condition was to the effect that, in case of difference of opinion as to the amount of compensation, the question should be referred to arbitration, and the award made should be taken as a full settlement of the question, and the legal effect was to prohibit an action until the amount was determined by the award. The court held that the partics had used sufficient words to make the reference to arbitration a condition precedent." ${ }_{21} \mathrm{Ac}$ cordingly, the words "condition precedent" are unnecessary. The sole question is, Did the parties desire arbitration for the purpose of determining their rights?

Had the Courts of England not yet made this point clear? It seems not. For in 1859, in the Court of Exchequer,"2 Pollock, C. B., refuses to sustain a plea based upon an arbitration covenant because "It falls within the rule which has been acted on for above a century, and according to which the superior Courts of law cannot be ousted of their jurisdiction by the nere agreenent of the partics; or, in other words, that an agreement to refer does not prevent the parties from resorting to a Court of law to enforce their rights or redress their urongs." ${ }_{23}$

"Ibid., p. 798. (I. E. "There is no decision which prevents two persons from agreeing that a sum of money slall be paid upon a contingency; but they cannot legally agree, that, when it is payable, no action shall be maintained for it." 8 Exch. R. 497, 498, 499.)

2050 N. Y. 250 , at p. 269.

${ }^{21}$ Italies ours.

${ }^{23}$ Horton v. Sayer, 4 H. \& N. 643.

${ }^{23}$ Ibid., p. 649. Italies ours. 
Baron Martin (who, it will be recalled, had himself been reversed in Scott $v$. Avery) says in this case: "I do not dissent; but I cannot distinguish this case from what is laid doun by Lord Campbell in his judgment in Scott $v$. Avery. It seems to me that, if that judgment is right, this plea is good; and I think that the decision in Scott 2'. Avery eannot be upheld unless the judgment of Lord Campbell is right; although I may observe that some of the learned Judges found their judgments on a contrary principle. Scott $v$. Avcry was nothing more than the case of a policy of insurance, with a clause that, in the event of any difference between the underwiters and the insurcd, it should be referred to arbitration. Lord Campbell certainly held that an agreement to refer any dispute to arbitration is binding, and that no action can be maintained until after an adjudication by the arbitrator. It seems to me," says the Baron further, "that Scott $v$. Avery has overmled all the previous decisions on the subject." He is of opinion, therefore, that "If parties choose to arrange that, before any action is brought on a policy of insurance, an arbitrator shall ascertain the sum to be paid," that seems to him "only a circuitous mode of saying that no action shall be brought." 24 And he is glad to find that under the 11th section of the Common Law Procedure Act of 1854, if action be commenced "after the parties have agreed to refer any differences to arbitration, the Court or a Judge may stay the proceed. ings." 25 In consequence, "That enactment," he says, "renders our decision in this case of less importance than it otherwise would have been." 26

In 1862 (in Exchequer), in Tredwen v. Holman, ${ }^{27}$ Baron Martin writes the prevailing opinion. He now holds valid

24 Horton v. Sayer, 4 H. \& N. 643, at p. 650. Italies ours.

${ }^{2 x}$ Ibid., pp. 650-651.

${ }^{20}$ Ibid., p. 651.

${ }^{27} 1$ Hurlstone \& Coltman 72. 
a provision in an insurance policy that "all other cases of dispute, of whatever nature, shall be referred in like manner;" i.c., conformably to the practice at Lloyd's or Royal Exchange, "to two professional average-staters, or to two other eompetent persons, with power to such two persons to appoint an umpire, and the award of such two persons shall be final;" "and no action at law shall. be brought until the arbitrators have given their decision." He overrules Horton 2 '. Saycr, in which he concurred, and says: "The third rule, which is incorporated with the policy, after providing for disputes as to average claims and claims of abandonment, expressly declares that all other cases of dispute, of whatever nature, shall be referred; and no action at law shall be brought until the arbitrators have given their dccision. The agreement is elear and unambiguous, and the parties probably meant to act upon Scott v. Avery and exclude the jurisdiction of the Courts of law, except for the purpose of enforcing the award to be made by the arbitrators." ${ }_{28}$ Here is the very clearest indication, not seven years after Scott $v$. Avery had been deeided, of what Baron Martin understood Scott $v$. Avery to mean. He says: "A ease of Horton v. Saycrs (supra) was eited and relied on by the plaintiff. But we are of opinion that this ease is governed by the case of Scott $v$. Avery, and not by that of Horton v. Sayers." 20 And by way of reinforeement: "The plaintiff is therefore in the wrong. The defendant proposed to him to refer the matter in dispute, in accordanec with the third rule, to which he refused to accede, and he has failed to perform that which is a condition precedent to his maintaining the present action." "30

His interpretation of Scott v. Avery is most lucid, and once more it would seem as if Coke's dictum had been

\footnotetext{
${ }^{23}$ Ibid., p. 81. Italics the Court's.

${ }^{20}$ Ibid., p. 81 .

${ }^{30}$ Ibid., p. 81. Italies ours.
} 
werthrown. But no. One year later, in Mills v. Bayley, ${ }^{31}$ Baron Martin retracts, pernits eounsel to eite without disapproval Milue $v$. Gratrix and King $v$. Joseph, of one flesh with Vynior's Case, and joins in invalidating a clause, in principle the same as that in Treduen $v$. Holman. II words are: "If this agreement had been simply that Neville should measure and ascertain the quantity of mud removed by the plaintiff, there would have been no difficulty, because he would not, strictly speaking, have been an arbitrator, and the authority conferred on him would have been irrevocable. But, with respect to the other part (as to settlement of any disputes that might arise out of the eontract) I ean see no distinction between that and an ordinary reference of matters in dispute, which is revoeable." 32 "... I regret that the law is so, and that the legislature, when they were dealing with the subject of arbitration, did not in all cases prohibit the revocation of references." 33

Even in Chancery, the Vice-Chancellor is slipping into the old rut. In 1861, but eight years after Scott v. Avery, there comes up Lee $v$. Page, ${ }^{34}$ where articles of copartnership provide that the parties submit all disputes to arbitration and until such arbitration take place, neither party may sue the other with reference to the affairs of the corporation. Kindersley, V. C., holds that although an arbitration clause is legal, there may not be a negative clause super-added to withdraw the dccision of the question from the tribunals of the country.

By 1867 the Court of Exehequer has swung far away from the prevailing opinion in Scott v. Avery. In Elliott

${ }^{31} 2$ IIurlstono \& Coltman 36.

32 Ibid., p. 41.

${ }^{23}$ Ibid., p. 41. Italies ours. The case is poorly presented and counsel for the plea apparently made no careful study of the authorities.

${ }^{34}$ Law Journal, N. S. Vol. 30, Part I, p. 857. 
r. Royal Exchange Assurance Company, ${ }^{3.5}$ a clanse in an insurance policy, almost identical with Baron Martin's conception of the clause in Scott v. Avery, ${ }^{36}$ is treated as void and the plaintiff is permitted to sue on the poliey, without a reference to arbitration. Now, Bramwell, who was defendant's counsel in Scott v. Avcry, takes the oecasion to say: "I7 "In the argument of that case (the arbitration clause in which was framed by Mr. Justice Cresswell), Mr. Manisty and myself were counsel for the defendants. We scarcely eited a case, but laid down a proposition which was almost immediately adopted by the judges below, and by the House of Lords. That proposition was that if two persons, whether in the same or in a different deed from that which creates the liability, agree to refer the matter upon which the liability arises to arbitration, that agreement does not take away the right of action. But if the original agreement is not simply to pay a sum of money, but that a sum of money shall be paid if something else happens, and that something else is that a third person shall settle the amount, then no cause of action arises until the third person has so assessed the sum. For to say the contrary would be to give the party a different measure or rate of compensation from that for which he has bargained. This is plain common sense, and is what I understand the House of Lords to have decided in Scott v. Avery."

In this opinion, Kelly, Martin and Pigott concur; but, as we have already seen, the Baron was in error in his construction of the decision of Scott $v$. Avery, just as he was in error in his argument as counsel in that case before the House of Lords. For research and industry he substituted ingenuity and subtlety-a not infrequent recourse of busy and successful practitioners. Like most of the

${ }^{35}$ L. R. 2 Exch. 237.

30 Supra, p. 186.

${ }^{37}$ L. R. 2 Exch. 237, at p. 245, 246. 
English lawyers of his day, he accepted Coke's dictum as part of the Common Law and searched no farther. In Scott $v$. Avery he permitted his adversary to eite Kill $v$. Hollister and Thompson $v$. Charnock, without criticism.

In 1870 we find Thomson $v$. Anderson, ${ }^{38}$ in Chancery, Malins, V. C., holds too, that a general covenant in partnership articles to submit differences to arbitration is revocable, notwithstanding the Common Law Procedure Act of 1854. Counsel for the plaintiff relies on Mills $v$. Bayley. Counsel for the defendant quotes Lord Cranworth (Drew v. Drew ${ }^{39}$ ) and IIarcourt v. Ramsbottom. Apparently he could find no other authorities-not even Dimsdale $v$. Robertson. The Vice-Chancellor says: "The next question is, whether this is a revocable instrument. Now, upon that subject I have had much argument, and I have been referred to authoritics. It is not questioned that before the statute 3 and 4 Will. 4, c. 42, all references to arbitration were revocable until the award was made"!!"40 Yet, he says, "but that a person should, when he had once made a reference to arbitration, be entitled from mere caprice to revoke it is, in my opinion, a monstrous state of things, and it has been so regarded by many Judges.' 41 Nevertheless, he feels constrained to follow Baron Martin in Mills $v$. Bayley" as "a distinct authority upon the point," with "nothing against it but that dictum of Lord Cranworth's" in Drew v. Drew ${ }^{43}$-which "did not apply to an English case." Therefore, he must find obsequiously that the arbitration is revocable and the Common Law Procedure Act had not changed the Common Law in this respect.

\footnotetext{
${ }^{88}$ It. R. 9 Eq. 523.

${ }^{23}$ See ante, p. 180. (2 Macq. 1, 4.)

${ }^{40}$ I. H. 9 Eq. 523, at p. 529 . Italies ours.

${ }^{41}$ Ibid., pp. 529-530. Italies ours.

${ }^{12}$ Ante, p. 188.

${ }^{43}$ See ante, p. 180.
} 
Next in order of examination is In Re Rouse and Meicr in the Court of Common Pleas ${ }^{44}$ in 1871 , wherein Willes, $J$. , permits himself to say, concerning the rule in Vynior's Case, "my act or my words cannot alter the judgment of the law to make that irrevocable which is of its own nature revocable." - "That law, as to arbitrations," he is betrayed into saying, "was never questioned." 45 "In the course of time it was thought desirable that submissions to arbitration should be irrevocable," but in his opinion: "The $9 \& 10 \mathrm{Wm} .3$, c. 15 , was the first but an imperfect step in that direction." 45 It follows for him that, since the contract in the case under review made no provision for making the submission a rule of court, it was revocable at the will of either party, in spite of the enactment by Parliament. The influence cven at this late day of the dictum in Vynior's Case is clearly demonstrated in the repeated references thereto by the judges. Montague Smith and Brett concur.

But one year later Caledonian Railway Company $v$. Greenock and Wemyss Bay Railway $\mathrm{Co}^{46}$ reaches the House of Lords, a case where the arbitration clause reads, "all differences which may arise between the parties hereto respecting the true meaning or effect of this agreement, or the mode of carrying the same into operation, shall, from time to time, so often as any such questions or differences shall arise, be referred to arbitration, in terms of the Railway Clauses Consolidation (Scotland) Act, 1845, and the provisions" (for arbitration in such act) are "incorporated with this agreement . . a as if they were verbatim inserted therein." This the Lords sustain, Lord Kinloch saying, "such arbitration clauses are now extremely common." 47

4 L. R. 6 C. P. 212.

4s Ibid., p. 217 . Italies ours.

* 10 Sess. Cases (3ril Series) (1871-2), 892.

"Ilid., p. 898. Italies curs. 
IIowever', in 1876, the Queen's Bench Division holds that even the Common Law l'rocedure Act had not made an agreement to arbitrate irrevocable. ${ }^{48}$ Blackburn here eites Mills $v$. Bayley and Rouse $v$. Mcier. ${ }^{49}$ Yet he says: "If the plaintiffs go on with the artion there is no remedy at all, but if the action is stayed they may get rid of the stay by offering to concur with the defendant in allowing the arbitrator to make his award, which it would be just and proper he should make." 50 And he asks: "Why should not this agreement be enforeed by a stay of the action, assming no reason on the merits to be shewn against it?" 5o But his eolleagues disagree with him. Quain, J., prevailing, goes back to Vynior's Case for his authority (p. 754).

A year earlier (1875) arose Edwards $v$. The Aberayron Mutual Ship Insurance Socicty (Limited), in Exchequer Chamber (Queen's Bench Division), ,1 a case on all fours with Treduen $v$. Holman. Blackburn votes to sustain the clause. Mcllor is of the same opinion. He relies on Tredwen $v$. Holman, saying: "I think it is quite competent for the society (the defendant mutual insurance society) to establish a domestic forum that shall decide all disputes which shall arise betucen the membcrs, and that they shall not resort to a court of lax,", ete.52 Lush concurs with this view. He finds that the contract means: "We hold vour vessel to be insured subject to the terms expressed in the articles', and, says he, "those terms are that in case of loss, or a claim for loss, the whole matter is to be investigated by the directors, the amount payable, if any, is to be ascertaincd by them, and their decision is to be final," etc. "'This being so, the ease is clearly within Scott $v$. Avery.", 53

"Handell v. Thompison, I. R. 1 (2. B. D. 748.

4s sice rinte, 1\% 1.11.

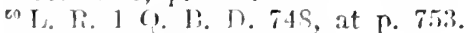

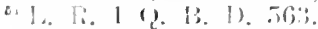

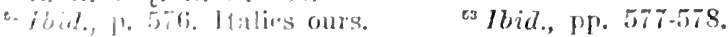


On appeal to the Exchequer Chamber, the Court below is reversed. Ampllett, B., says the question whether this clause is "void as being against the policy of the law" is settled by Scott $v$. Avery. IIe refers to Tredwen $v$. Holman, Elliott v. Royal Erchange Assurance Co. and Dawson v. Fitzgerald and finds the case before him is governed by Treducn $v$. Holman, but votes for reversal becanse the directors came to a decision without hearing the plaintiff, and because they were arbitrators. "The delieate task of adjudicating between their own socicty and a member" required them "to act judicially and with perfeet fairness and impartiality between the parties." Consequently, to come to a decision without giving the plaintiff an opportunity to be heard "was contrary to every principle of justice, and ought not ... to be held, by any Court of Law or Equity, to be binding upon him." ${ }_{54}$

Pollock, B., says the case comes within Scott v. Avery, Tredwen v. Holman and Elliott v. Royal Exchange Assurance $C o$. and votes for affirmance. Archibald concurs.

Brett, J., later Lord Esher, writes for reversal. He whittles down Scott $v$. Avery until there is little left of it. He examines the rules of the defendant company and finds that "The stipulations as to the procedure before the average adjuster shew that those who drew the rules intended that there should in all the inquiries be a judicial investigation before a tribunal; which," says he, "is therefore a judicial tribunal." These rules do not leave "the liability to pay to be established before the ordinary courts," but in fact, as it seems to him, are "intended to create a tribunal to hear and determine every question which may arise in respect of a policy made with the society, and to determine everything finally and compulsorily, so as to prevent any application to the ordinary courts." ${ }_{55}$ We may say that, in his legal inter-

${ }^{54}$ Ibid., p. 579.

${ }^{55}$ Ibid., p. 591. Italies ours. 
pretation of the terms of the policy, the learned judge was entirely correct. "Then arises the question," he says, "what is the law?" Preferring to follow Horton $v$. Saycr, ${ }^{56}$ he quotes the opinions of Pollock and Bramwell, the latter especially upon the meaning of Scott $v$. Avery. And here, too, he is astute, for both Polloek and Bramwell, as we have already seen, had very much narrowed the meaning of Scott $v$. Avcry. Brett observes that all the judges say "You camnot oust the courts of jurisdiction." ITere, he finds a clanse which in praetical effect leaves nothing for the eourts to do exeept enforee an award. Ergo, he argues, this must be void. Kelly, C. B., agrees with lim but admits that "undoubtedly there is much in the language of Lord Campbell in his judgment which, taken by itself, might seem to shew, as Baron Martin ${ }^{57}$ (I think, ineorreetly), held, that it put an end to the doctrine against the ousting of the jurisdiction of the Courts." ss

This ease is frequently eited, espeeially in American eourts, in support of the general doetrine that "You camnot oust the eourts of jurisdiction by a general arbitration clause," and as indieating that Baron Martin was in error in stating that Scott $v$. Avcry had reversed " all other English eases." But a closer study of the case reveals that Blaekburn, Mellor, Lush, Amplilett and Pollock follow Tredwen $v$. Molman and the Cranworth-Campbell interpretation of Scott $v$. Avery; while only Brett, later Lord Esher, and Kelly follow Bramwell's narrower interpretation.

Seventeen years later (1892) in Trainor $v$. Phocnix Fire Ass. Co., ${ }^{59}$ Lord Coleridge, then Lord Chaneellor, criticises Lord Esher sharply for his endeavor in the

se Se ante, pp. 185-186.

${ }^{87}$ In Horton v. Sayer, 4 H. \& N. 642, at p. 649. See ante, p. 186.

${ }^{68}$ L. R. 1 Q. B. I. 563 , at p. 598. Italies ours.

se post, pp. $211-212$. 
Aberayron case to limit the scope and meaning of Scott $v$. Avery as an authority, and thirty-two years later (1907) in Gaw v. British Law Fire Ins. Co., Holmes, L. J., makes it clear that Brett's views were not to be treated as prevailing in the Aberayron case; indeed, that in the later case of Scott v. Mcrcantile Accident and Guarantee Ins. Co., which we shall review in a moment, "Lord Esher himself gave a judgment absolutely inconsistent with his dicta in the Aberayron case." "60

But in 1876, Lord Coleridge himself had not yet overcome his earlier views, which, as expressed by him in Scott v. Avery, differed sharply with those of Lords Cranworth and Campbell. In Dawson v. Fitzgerald (Excheq. Div.) ${ }^{61}$ he adopts Bramwell's statement: "If two persons, whether in the same or in a different deed from that which ereates the liability, agree to refer the matter upon which the liability arises to arbitration, that agreement does not take away the right of action." 62 In expressing his opinion in Scott $v$. Avery, Lord Coleridge, it will be recalled, had said: ${ }^{63}$ "If two parties enter into a contract, for the breach of which in any particular an action lies, they cannot make it a binding term, that in such event no action shall be maintainable, but that the only remedy shall be by referenee to arbitration." But he said, "Whether this rests on a satisfactory principle or not may well be questioned; but it has been so long settled, that it cannot be disturbed." In 1892, however, at three score years and ten, Lord Coleridge thought differently. ${ }^{64}$

Lord Esher, too, went very far in the wrong direction, before he returned to the true line. In 1883, as Master

See post, pp. 213-214.

${ }^{61}$ L. R. 1 Exch. D. 257 , at p. 260.

6. L. R. 2 Exch. 237 , at p. 245 (Enliott r. Royal Exchange Ass. Co.).

$\approx 5$ H. L. C. at p. 841 . Italies ours.

ose post, pp. 210-212. 
of the Rolls in Fraser $v$. Ehrensperger ${ }^{65}$ he revives Lord Coke's dictum. He says: "In Vynior's Case Lord Coke says, "If I make a letter of attorney to make livery or to sue an action, \&c., in my name,' 'or if I submit myself to an arbitrament, although these are made by express words irrevocable, or that I grant or am bound that all these shall stand irrevocably, yet they may be revoked.' ", 60 This is a case in which an agreement to arbitrate is revoked by one of the parties. Brett now holds that even the statutes of Parliament ( $3 \& 4$ Wm. 4 , c. 42 and Common Law Procedure Aet, 1851) have not removed this right to revoke, which he declares is "one of the incidents of an arbitrator that he is a mandatory, and that by the law of England before the mandate is completed it ean be revoked and withdrawn." ${ }^{\circ 7}$ As we shall see, however, Lord Esher, like Lord Coleridge, lived to modify these views.

Even the Act of 1889 did not stop Lord Esher at this time. In 1890, in Smith of Service, ${ }^{68}$ he reverses Coleridge and Willes in the Court of Appeals and holds that, where an agreement in a charter party provides for a reference to three parties, one to be appointed by each of the parties and the third by the two so appointed, the Court has no power, "either under or apart from the Arbitration Act, 1889,' to order a party who fails or refuses to appoint his arbitrator to make such an appointment. Here he said to counsel: "A Court of Equity had no power to decree specific performance of an agreement to refer to arbitration; but you suggest that the Courts of Common Law harl such a power." To which counsel reply: "Yes; the rule of Court was in itself a decree of speeifie perform-

\footnotetext{
${ }^{*}$ L. R. 12 Q. B. I. 310.

Tbid., p. 316 .

* Ibid., p. 318.

H. R. 25 Q. B. D. 545.
} 
anee." ${ }^{60}$ Lindley, L. J., says: "If that argument were sound, a great many things would follow from it. It would follow that the Court could have done a great number of things in arbitrations which the Court has declined to do over and over again." Not always, as we have seen. "In the first place, I do not see why the Court should not have been asked to make an order of this sort ages ago." They were and they did, only the learned judge did not know it. "I cannot see why it is consistent with any sueh theory that there should be a total absence of any authority for the enforeement of a submission in the same way that the Court has enforced an award. It has long been settled law that the Court will not grant specifie performanee of an agreement to refer; but, if this argument is sound, it is difficult to see why there should not have been speeific performance of a portion of the agreement-that is to say, why one party should not have had a decree eompelling the other party to proceed and appoint an arbitrator." $\tau_{0}$ But see later, in 1916, post p. 223, and per contra Manchester Ship Canal Co. v. S. Pearson \& Son, Limited, in Q. B. Div., C.A., L. R. Q. B. D. 1900 , Vol. II, at 606.

No one diseusses Halfhide $v$. Fenning, Waters $v$. Taylor, Dimsdale v. Robertson or Harcourt v. Ramsbottom. The only cases referred to at all are Gumm $v$. Hallett, ${ }^{i 1}$ Thomson $v$. Anderson, ${ }^{72}$ Randell v. Thompson, ${ }^{73}$ In re Rouse and Meicr, ${ }^{74}$ Fraser v. Ehrensperger, ${ }^{75}$ Davila $v$. Almanza. ${ }^{76}$

But Esher and Coleridge were not alone. In 1889, in the Court of Appeal, before Cotton, Lindley and Lopes,

\footnotetext{
${ }^{69}$ Ibid., p. 547.

${ }^{70}$ Ibid., pp. 551-552.

${ }^{11}$ L. R. 14 Eq. 555.

${ }^{72}$ L. R. 9 Eq. 523.

${ }^{73}$ L. R. 1 Q. B. D. 748.

${ }^{74}$ L. R. 6 C. P. 212.

${ }^{75}$ L. R. 12 Q. B. D. 310.

${ }^{70} 1$ Salk. 73.
} 
came Davis v. Starr. ${ }^{37}$ The Common Law Proeedure Act of 1854 provided "that whenever the parties to any instrument in writing thereafter made shall agree that any then existing or future differences between them or any of them shall be referred to arbitration, and any one or more of the parties so agreeing, or any person or persons claiming through or under him or them, shall nevertheless eommence any aetion against the other party, or any person claiming through or under him, "it shall be lawful for' the court or a judge, on the defendant's application, after appearance and before plea or answer, "upon being satisfied that no sufficient reason exists why such matters eannot be, or ought not to be, referred to arbitration aceording to such agreement as aforesaid, and that the defendant was, at the time of the bringing of such action or suit, and still is, ready and willing to join and concur in all acts neeessary and proper for causing sueh matters so to be deeided by arbitration, to make a rule or order staying all proceedings in such action or suit, on such terms as to costs and otherwise as to such court or judge may seem fit.' "' The Court refuses to stay an action upon an agreement for serviees, wherein there was the following elause: "If, during the continuance of this agreement, or at any time afterwards, any difference shall arise between the parties hereto, ... in regard to the construction of any of the agreements herein contained, or to any payment, act, deed, matter or thing relating to this agreement, or arising therefrom, such difference shall be forthwith referred to two arbitrators, one to be appointed by each party in difference, or to an umpire to be chosen by the arbitrators before cntering on the consideration of the matters referred to them, and every such reference shall be decmed an arbitration within the Common Law Procedure Act 1854, and be subject to the provisions as to arbitration contained " 60 L. T. R. 797 . 
in the said Act." Cotton says: "Before the Act the courts had hold that there was no power to stay an action in such circumstances, and that such an agreement ought not to be enforced, as it was an attempt to oust the jurisdiction of the ordinary tribunals. But the Common Law Procedure Act 185t, though it does not deprive the court of jurisdiction to deeide the dispute between the parties, enables the court, by way of speeifie performanee, to stay an action which is brought in violation of an agreement to refer to arbitration." is IIere each party charged the other with breach of contraet. The judge thinks "a jury is not an improper tribunal for trying the action." is

But this ease is elearly overruled by Scott v. Mercantile Accident and Guarantce Insurance Company, ${ }^{79}$ deeided in 1892, and, in 1897, by Renshaw v. Queen Anne Mansions Co. ${ }^{80}$

In 1875, in the House of Lords, in Bremner ' . Elder, ${ }^{81}$ a Seotch ease eame up concerning a dispute between two parishes as to the settlement of a pauper. It was referred by them to the decision of a Society of Inspectors which was in the habit of deciding such questions by vote at their general meetings. Though no definite persons were named and it was eonceded to be uneertain what members would be present, the House of Lords sustained both the reference and the award.

Lord Hatherley likens this ease to a general agreement "to refer disputes to a body like a Chamber of Commeree" and ean find no Scoteh decision against it. He would "be extremely sorry," he says, ". . . f for your Lordships to eome to any sueh conclusion in this or in any other similar ease with respect to an award decided by a body like this Soeiety of Inspectors" which seems

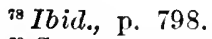

${ }^{79}$ See post, pp. $213.214,66$ I. T. R. 811.

${ }^{80}$ See post, pp. 214-215, L. R. [1897] 1 Q. B. D. 662.

82 Sess. Cases (4th Series) 136, at p. 143, 144, 145. Italics ours. 
to be "composed of men eminently qualified to express a judgment upon a point of the character which had arisen in the dispute between these parishes." These men have "apparently so far acquired the confidence of persons who might be brought into litigation for very small amounts of money, for which economical and expeditious justice would naturally be desired by all parties, that such disputes were frequently referred to them' and His Lordship would be "extremely sorry that a body so competent as this in respect of knowledge and aequirements should not be held to be in law eompetent to undertake the duty of arbiters." He finds that their decisions are rarely questioned, though they are not a corporation, but "are a fluctuating body, and it is not always, indeed but seldom, that you can know who are or who are not to be the particular persons who will sit in judgment upon a particular matter. But why that should disqualify or incapacitate them from being seleeted as arbiters... on the strength of an abstract or an a priori reasoning, it appears . . . very difficult" for him "to comprehend." Fle accordingly holds and the other Lords agree that there is no authority against such a reference. This is clear authority for the validity of a general reference to a Board of Trade or Chamber of Commerce.

In 1878, in Queen's Bench Division on appeal from a decision by Lopes, J., Cockburn and Mellor hold valid, in Moffat $v$. Cornelius ${ }^{82}$ a elause in a contract of sale of a cargo of maize in the following form: "Should any dispute arise, contract not to be void, it being agreed by buyers and sellers to leave the same to be settled by two London corn factors respectively chosen, with power to call in an umpire, whose decision is to be final; and this stipulation to be made a rule of court of any of the divisions of the Migh Court of Justice in London on the application of either party." Biglıam, for the plaintiff, o2 26 Weekly Reporter 914. 
says: "Where the contract itself contains an agreement to refer, the cases of Scott v. Alery and IIorton v. Sayer apply. This ease is within the deeision of the Court of Appeal in Randcll v. Thompson." To which Cockburn. C. J., replies: "The distinction there made is subtlety. itself. ... Where a person has bound himself solemnly to an agreement, he alone cannot revole it. The stipulation to refer is part of the agreement, and forms part of the consideration for it." 83 Mellor was of opinion that the provision of the Common Law Procedure Act of 1854 would be rendered "nugatory, and it might as well be expunged" if the doctrine contended for prevailed. If it did, says he: "Any person desiring to aroid an arbitration might revole at any time." 84

In 1877 we find Mellor, J., saying in another ease: ${ }^{85}$ "If two persons ehoose to agree that neither of them shall have any right of aetion under an agreement until a third person has given his deeision upon the matter in question, as in the ease of a wager, \&c., the agreement is binding. It is quite reasonable that people should endeavor as far as possible to avoid the necessity of having recourse to courts of law." 86

And in 1875, in Rolls Court ${ }^{87}$ (Equity), we find Sir G. Jessel saying: "Certainly these arbitrations have not been looked upon very favorably by eourts of law. Many striet and some absurd rules were laid down at a period when courts of law seemed to eonsider a referenee to arbitration to be something wrong, or as an attempt to oust the ordinary jurisdietion of the court. That period has passed away. Both the Legislature and the Judicature

${ }^{8}$ Italics ours.

${ }^{84}$ Italics ours.

${ }^{85}$ London Tramways Company v. Bailey, L. R. 3 Q. B. D. 217, at p. 221.

${ }^{88}$ Italics ours.

${ }^{87}$ Ripley v. Great Northern Railway Company, 31 L. T. R. 869 , at p. 870 . Italies ours, 
rather encourage than discourage references to arbitration when fairly and honestly conducted, and, so far as arbitrators have power to do so, and eapacity for doing so, legally conducted."'ss

In 1879 , in the Chancery Division, ${ }^{89}$ Piercy $v$. Young comes up. The suit is for a partnership accounting. The arbitration clause in the partnership articles is simply: "Any differences or disputes which may arise between the partners shall be settled by an arbitrator to be agreed upon between the partners, and lis decision shall be final and binding upon all parties." Here was no eovenant that the submission to arbitration should be made a rule of court. The suit was for an accounting brought by one partner against the other. Now, Jessel, M. R., says: ". . . we are all clearly of opinion that a general agreement to refer matters in dispute to arbitration cannot be revoked. The authorities cited have no application." (The authorities cited are old friends. They include Mills $v$. Bayley and Re Rouse and Meier.) In a footnote it is said that in a similar case of Christie $v$. Noble, before Jessel, M. R., on the 16th of April, 1880, "His Lordship followed the above decision, considering himself bound by it. His Lordship observed that, although a particular submission to arbitration might be revoked, a partner could no more revoke a general agreement to refer than he could revoke any other contract in the partnership articles." 90

In the main case, the suit is not stayed because the judges agree that the disputes alleged are not within the meaning of the articles because they do not relate "to the carrying on of the partnership business." The questions presented were inter alia "whether the partner-

"See study, “Arbitration as a Condition Precedent," Harvard law Rerien, Yol. 11, p. 234.

${ }^{84}$ L. R. 1 t (h. D. 200.

"Ibid., p. :03. Italies ours. 
ship has been dissolved and the Plaintiff. has sold his share" and whether certain other shares were "purchased, not for the benefit of the partnership, but for the benefit of the Plaintiff and the Defendant." Yet Jessel says: ${ }^{91}$ "Of course persons can agree to refer to arbitration not merely disputes between them, but even the question whether the disputcs between them are within the arbitration clause." 92

In Collins $v$. Locke ${ }^{93}$ (1879), Sir Montague Smith, delivering the judgment of the House of Lords, says: "The question so raised is, whether the general arbitration clause (elause 11) affords an answer to the action, there having been no arbitration and no award under it. Since the case of Scott $v$. Avery, in the House of Lords, the contention that such a clause is bad as an attempt to oust the Courts of jurisdiction may be passed by. . . . That question must be determined in each case by the construction of the particular contract, and the intention of the parties to be collected from its language." ${ }_{94}$

In 1885, in the House of Lords (Spackman v. Plumstead Board of Works $^{95}$ ), a clause making the engineer of the Metropolitan Board of Public Works the sole arbitrator under a building contract is sustained upon the principle that ever since Scott v. Avery, parties may provide any method they choose for making it "part of the contract itself that the right of action, so to say, before it could arise was to be ascertained by the decision of arbitrators; in which the right itself, the constitution of the right, was not to be perfect and absolute under the contract until arbitrators had decided something" and that the Court had held in Scoit v. Avery "that to be

\footnotetext{
${ }^{91}$ Ibid., p. 208.

92 Italics ours.

${ }^{93}$ L. R. 4 App. Cas. 674.

on Ibid., p. 6\$9. Italies ours.

${ }^{\circ}$ L. R. 10 App. Cas. 229.
} 
inerfectly good, and that in that case, until such a decision had. been made, no right upon which an action could be founded arose." 96

The rule as put by Maule, J., in Scott $v$. Avery, in the Court below ${ }^{97}$ is frequently quoted: "There is no decision whieh prevents two persons from agreeing that a sum of money shall be paid upon a contingency; but they eannot legally agree, that, when it is payable, no aetion shall be maintained for it."

In 1887 , in Viney $v$. Bignold, ${ }^{98}$ the elause under review was: "If any difference shall arise in the adjustment of a loss, the amount (if $a n y$ ) to be paid by the soeiety shall, whether the right to recover on the poliey be disputed or not, and independently of all other questions, be submitted to the arbitration of some person to be chosen by both parties," (or two, with an umpire in the usual fashion) "and the award of the arbitrators or umpire (as the case may be) shall be conelusive evidenee of the amount of the loss, and the party insured shall not be entitled to eommence or maintain any aetion at law or suit in equity upon his policy until the amount of the loss shall have been referred and determined as hereinbefore provided, and then only for the amount so awarded... and the reference in all other respects to be subject to such rules and conditions as are usually inserted in orders of reference at nisi prius if the parties differ about the same."

The covenant is sustained. The courts are now turning from the narrow construction of Scott $v$. Avery.

${ }^{\circ}$ L. R. 10 App. Cas. 229, at p. 236. Italies ours.

8 Exch. Rep. 487 , at p. 499.

* L. R. 20 Q. B. D. 172. Italies ours. 


\section{EHAPTER XVI}

THE JUDICIAL CORRECTION OF A JUDICIAL ERROR (ENGLAND, 1853.1916)

If now we spread upon the table the various leading eases we have been examining, we shall find it practicable to set down certain definitive points as the culmination of the precedents.

1. Lord Chancellor Cranworth and Lord Campbell, in Scott v. Avery (1855-1856), Lord Chancellor Sugden in Dimsdale $v$. Robertson (1840), Lord Eldon in Waters $v$. Taylor (1807-8) and in Harcourt v. Ramsbottom (1820), Lord Kenyon in Halfhide v. Fenning (1788), Baron Jeffreys in Norton $v$. Mascall (1685), Sir Henry Montague in Browne v. Downing (1620), Yelverton and Laken in 8 Edw. IV, 9 and 10 (1468), the entire bench in Brode $v$. de Ripple (1375), the entire bench in 1389 and the Judges during the reign of Henry III (1216-1272) all agree upon what may now be paraphrased as follows:

"Mutual promise to abide by the award of certain men is good enough to bind them to abide by the agreement;" ..." it is fit that the same should be performed." If either revokes, he has done something "bad in equity." "Public policy requires that effect should be given to such contracts," and that the parties should be left "at full liberty to refer their disputes at pleasure to public or private tribunals." Parties may select any means they choose for determining upon what basis they shall release each other, or what shall be due one from the other, and arbitration is a convenient, inexpensive and desirable means for accomplishing such a result. He who cancels 
his obligation so to arbitrate is guilty of inequity and is not deserving of the aid of a court of equity.

2. The dictum in Tynior's Case that submission or agreement to arbitrate is revocable at any time has disappeared. Like an old scar disappearing under a new skin, it is covered with a new doctrine-i.e. that contracts which oust the courts of jurisdiction are void, as against public policy. Under this doctrine, no actual revocation need be made; no formal instrument equivalent in value to the original grant need be exccuted, and aetual notice of revocation to the arbitrator becomes unnecessary. If the plaintiff brings suit, it is no defense that an arbitrament is pending or has been agreed to-even if the consent be followed by an order of the court.

This is the result of Hide $v$. Petit (1670), Kill v. Hollister (17t6), Milne $v$. Gratrix (1806), King v. Joseph (1814). Out of all these cases, however, but one rests squarely upon the doctrine of "ousting the courts of jurisdiction" and this is Kill $v$. Hollister (directly overruled in Malfhide v. Fenning).

3. It is impossible to reconeile Kill. $v$. Hollister, Hide $v$. Petit, Milne v. Gratrix or King $v$. Joseph with the principles and decisions we have set down in Proposition First (supra).

4. To resolve this dilemma we must conclude that, so far as precedential value is eoncerned, by $1856 \mathrm{Scott} v$. Avery (1855-1856) in the House of Lords by Lords Cranworth and Campbell, Dimsdale $v$. Robertson (1840) in Chancery by Lord Sugden, IVatcrs v. Taylor (1807-8) and Harcourt $v$. Ramsbottom (1820) by Lord Eldon had overruled Nilne $v$. Gratrix (1806), King v. Joseph (1814), Hide v. Petit (1670), and Kill v. Hollister (1746). And so far as Vynior's Case is concerned, the dietum of revocability was not only destroyed in authority by these (ases, but was long before then destroyed by Norton $v$. Uascall (1685) and Browne v. Downing (1620). 


\section{CORPECTION OF A JUDICIAL ERROR פOY}

5. Though in Scott $v$. Avery all concur that "to oust the comrt of jurislietion" is against publie policy, the ratio decidendi is that it is sound policy to agree not to resort to the eourts of law or equity if the parties can find some other way out, and they may agree that until the determination of the claims of the parties is made by arbitration-even though this determination in effeet finally adjudieates and determines the rights of the parties-no resort to the courts shall be had.

6. Referring $10 \mathrm{w}$ to another proposition-never questioned throughout all the deeisions, viz: that the award of the arbitrators, when made, is binding unless it can be set aside for "matter of equity" (see Price $v$. Williams " - the case in which Lord Eldon was counsel)-we come to this praetieal result: If the parties agree to resort to arbitration they should go to arbitration. If they do so, the courts will not set aside the award, save upon grounds of equity. Therefore, the sole question in each ease (regardless of the particular words of the contract) comes down to this: Have the parties indicated that they desire -in Lord Eldon's words, "are anxious" - that resort to the courts shall not be had until the private tribunal they have selected has had opportunity to pass upon the matter?

We submit that this is the elear and binding result of the decision in Scott v. Avery, and of Waters $v$. Taylor, and that all other construetions of these deeisions have been due to misunderstanding of their effeet upon the preceding authorities.

We have now pictured the confused state of English law upon this subject down to 1892 . Is it to be wondered at that Ameriean lawyers and Ameriean judges should have found it difficult to believe either that the dietum in Vynior's Case was no longer English law, or that Malfhide $v$. Fenning was authority, and more difficult still to determine whether the Cranuorth-Campbell version of

\footnotetext{
${ }^{1}$ Supra.
} 
$S c o t t v$. Avery was to be taken rather than the BramwellEsher version. Like earnest adherents to the faith, Amerjean judges asked only for authoritative versions of the book. The high priests at the Bar presented late editions, but conflicting in chapter, verse and text. No eitation of English cases prior to 1892 which did not give all the cases and arrange them historically could, as we now sce it, be treated as trustworthy.

But in 1892 a change came about-not by act of Parliament, but through the clear analysis of English judges themselves. At last the error became visible and was eorrected.

In 1894 we come to the case of Hamlyn \& Co. v. Talisker Distillery in the House of Lords (where sit Lord Chancellor Herschell, Lord Watson, Iord Ashbourne, Lord Macnaghten, Lord Morris and Lord Shand). ${ }^{2}$ Here is a contract between an English and a Scotch firm containing this clause: "Should any dispute arise out of this contract, the same to be settled by arbitration by two members of the London Corn Exchange, or their umpire, in the usual way." Was this a valid elause? The appeal comes up from Scotland. The Scotch judges had held that the contract was to be governed by the laws of Scotland and that as Scotch law then stood, such a clause was invalid, for that no arbitrator was named in the contract. In answer, the contention was made first of all that the parties intended this to be governed by English law. (The argument is referred to later.) And so the Court decides. In the second place, it is argued that by the law of England, such a clause is valid-not revoeable. Does Coke's dictum finally prevail, or is it Halfhide $v$. Fenning and Cranworth's rule in Scott v. Avery?

The Court holds most decisively that under the law of Engrand such a clause is valid. Watson, Lord, says: "The jurisdiction of the Court is not wholly ousted by such 221 Session Cases (4th Series) 21. 
a contract. It deprives the Court of jurisdietion to inquire into and decide the merits of the ease, while it leaves the Court free to entertain the suit, and to pronounce a decree in conformity with the award of the arbiter. Should the arbitration from any eause prove abortive, the full jurisdiction of the Court will revive, to the effect of emabling it to hear and determine the action upon its merits. When a binding reference is pleaded in limine, the proper course to take is either to refer the question in dispute to the arbiter named or to stay procedure until it lias been settled by arbitration." " 3

Two years earlier (1892) in the House of Lords, in Caledonian Insurance Co. v. Gilmour ${ }^{4}$ there had come up for review a clanse in which it was provided that any difference as to the amount of loss or damage should be referred to arbitration and no suit at law should be begun until the arbitrators made their award. No arbitrators were named. Here, too, it had been argued that, as the Scotch law then stood, such a clause was void and it was argued further that as the case had arisen in Scotland, the Seotch law should be applied. But by this time the lawyers in the House of Lords understand clearly the effect of Scott v. Avery. Lord Herschell (Lord Chancellor) says: "I may add that the reasoning of the noble and learned Lords who took part in the decision of Scott $v$. Avery appears to me completely applicable to the present case. Its cogency is not affected by any of the distinctions which then existed between the law of England and that of Scotland in relation to arbitrution clauses." 5 And Lord Watson says:" "Upon the question whether a reference like the present, by reason of its possibly devolving upon the arbiters the decision of the matters specified

s Ibid., p. 25.

${ }^{4}$ L. R. [1893] App. Cas. 85.

- Ibid., p. 90. Italics ours.

- Ibid., p. 96. 
. . becomes obnoxions to the charge of invading the iurisdiction of Mer Majesty's Courts, the judgment of this House in scott $v$. Avery is a direct authority. No doubt the judgment was given in an English suit; but that circumstance does not detract from its weight, because, until modified by comparatively recent legislation, the law of England went beyond that of Scotland, and held that no agreement to refer future disputes to arbitrators, whether named or not named, could oust the jurisdiction of the Courts or disable either of the contracting parties from resorting to them." " Since the terms of the poliey in Scott v. Avery are "substantially the same with those which occur in the policy", in the case at bar, he can find no distinction. He quotes freely from Lord Campbell's opinion in Scott $v$. Avery and says "the main ground of judgment is expressed by him in these terms (1): 'Now, in this contract it is stipulated, in the most express terms, that until the arbitrators have determined, no action shall lie in any Court whatever. That is not ousting the Court of their jurisdiction, because they have no jurisdiction whatsocver, and no cause of action accrues until the arbitrators have determined.' "'

In the same year (1892) also, Lord Coleridge in the Queen's Bench Division in Trainor v. Phænix Fire Assurance Company" had said, ${ }^{8}$ the "old doctrine that you could not oust the jurisdiction of the court by an agreement to refer everything, even to refer the cause of action itself," was overruled in Scott $v$. Avery. "Whether that (the "old doctrine") was a wise holding of the law is not for me to say. Judges of great authority have in the course of their judgments thrown considerable doubt on the judgment of the Lords in that respect." Again

Ttalies ours.

"65 L. T. R. 825.

- He was then 70 years old; he died two years later. See Encyclopadia Britanuica, 11th Ed., Vol. 6, p. 677, art. "Coleridge." 
he says: "Lord Cranworth, who is no mean authority, as well as that very great authority Lord Campbell, both said in terms that in their judgment it did not make the slightest difference whether it did refer other things or not, because if it did refer other matters it was equally good. Therefore Scott v. Avery,"' now says Lord Coleridge, "is a case to show not that the jurisdiction of the courts has been or ean be ousted, as has been sometimes suggested, but that you do not oust the jurisdiction of the court, and do not come within the authority of the earlier cases ... because you refer the question of liability, as well as the question of amount; and one of the judges, ${ }^{10} \mathrm{I}$ think in the Exchequer Chamber, eertainly in the House of Lords, points out that for the asecrtainment of the amount of liability it must often be essential to go into the principal question of liability itself, and to ascertain not only whether the liability exists to any extent, but also whether it exists at all, and, although that must be so in many cases, nevertheless it has never been suggested that the jurisdiction of the courts was ousted." 11 And then His Lordship makes this acute comment upon the cases between 1855 and 1892 which we have been studying:

"I am perfectly aware that it often happens that when strong judges do not like a decision they give judgments limiting the effect of the decision, and as much as possible minimising the alteration of the law, if alteration of the law there be." 12 How true this was! "Now that, I take it," says he (becoming more specific), "is really the substance of the reason of the judgments in Edwards $v$. The Aberayron Company. ${ }^{13}$ My learned brother, the Master of the Rolls, goes the full length of suggesting that

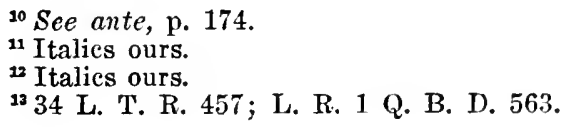


the Ilouse of Lords did not hold, and would have been wrong if it had held, that a submission to arbitration of all matters in dispute would be a good condition precedent to the maintenance of an action on any of them." 14 "But," says Coleridge, "he stood alone in that respect" -which is a little unfair to the learned Master of Rolls, because, as we have seen, he did have company in "limiting the effect"' of Scott v. Avery; Kelly, C. B., stood with him in that case and in other eases. Iord Coleridge himself had adopted Bramwell's explanation of Scott $v$. Avery. ${ }^{15}$ But my Lord Coleridge's ripe judgment ${ }^{16}$ eondemns only such elauses as these: "we agree that no cause of action under any circumstances shall arise upon this policy with which the courts shall deal," or "under no circumstances shall the courts of law have anything to do with disputes arising under this clause." Sucl clauses would be void, beeause they would "elose the doors under all circumstances, and under every coneeivable state of the case." And so it is held clearly that, under Scott $v$. Avery, the very liability itself may be determined by arbitration and the determination of arbitrators in such a case is a condition precedent to any application to the courts.

Coleridge does not rest his view, it will be observed, upon the Arbitration Act of 1889-he does not even refer to the statute law. Collins, J., his colleague, does refer to it as indicating that beeause at Common Law there was no existing means of effectuating arbitration covenants, the Legislature had said, "We will cnable a judge to com-

${ }^{1+}$ Italies ours.

${ }^{15}$ Dauson v. Fitzgerald, ante, p. 195.

10" On the whole, he was not so strong a man in his judicial capacity as Campbell or Cockburn; but it must be arlmitted that his seholarship, his refinement, his power of authority, and his charaeter raised the tome of the bench, while he sat upon it, and that if it has been adorned ly greater julicial abilities, it has hardly ever known a greater combination of varied merits." Encyclopadia Britannica, 11th Ed., Vol. 6, p. 677. 
pel a party under such a contract, although he now refuses to carry it out, to have the question not simply of liability, but the amount, or whatever comes within the contract, decided, not by the tribunals of the country, but by a private tribunal, namely, arbitration." 17 "How can it be said that it is contrary to public policy that private tribunals should determine the question of liability?" asks Collins, when "the attitude of the Legislature towards private tribunals" is to give "power to a judge to compel the parties to an agreement to oust the jurisdiction of the Superior Court." IIe says further (concerning the Arbitration Act of 1889): "That clause, as I understand it, being merely a re-enactment of the old section of the Common Law Procedure Act, was meant to meet the diffieulty where, there being a cause of action, the parties had agreed that the cause of action should be ascertained by arbitration. In that state of facts, there was no means, at Common Law at all events, whereby the parties could be made to carry out their agreement, and try by private tribunal instead of trying by the courts, and therefore diseretion was given to the judge to interfere and stay." In other words, as the judges now understand it, the arbitration covenant was not a nullity -it was merely unenforceable by specific performanee. The Act of 1889 did not change the right. It merely extended the remedy. The failure to apply the remedy of specific performanee was judicial error. If Baron Jeffreys and Sir Henry Montague had been followed instead of Lord Coke, no such difficulty would have arisen.

In 1892 also the Court of Appeal (Lord Esher, M.R., Fry and Lopes, J.J.) in Scott v. Mercantile Accident and Guarantee Insurance $\mathrm{Co}^{18}$ had held valid a clause reading: "If any dispute or difference shall arise between the assured, or any claimant under this policy, and the

${ }^{17}$ Baron Jeffreys' doctrine is at last vindicated. Ante, p. 135.

${ }^{18} 66$ L. T. R. 811. 
company as to any claim for loss or any other claim against the company, or in any way relating to or arising out of this policy, all such disputes or differenees shall be referred to the decision of an arbitrator to be appointed by the parties... and any such arbitration in England may be made a rule of court and the company shall not be liable in respect of any claim for loss, or for any act, neglect, or default in the execution of any of the powers and authorities given to it by the policy or otherwise, unless and until the liability of the company and the amount thereof, if not admitted, shall have been determined by such arbitrator, arbitrators, or umpire, whose award thereon shall be a condition precedent to any liability of the company or any right of action against the company in respect of such claim, and the award only shall be sued upon."

Now Lord Esher says: "The effeet of the clause in this policy is governed by the decision in Scott $v$. Avery, and arbitration is a condition precedent to the plaintiff's right of action," thus clearly reversing his dictum in Eduards v. Aberayron Mutual Ship Ins. Society, ${ }^{19}$ as (1892) Lord Coleridge pointed out in Trainor v. Phoenix Fire Assurance Co. and Holmes, L.J., pointed out in 1907 in Gaw v. British Law Fire Insurance Co. ${ }^{20}$

In 1897, in a case in the Queen's Bench Division, ${ }^{21}$ the contract for the employment of the plaintiff for five years contained a provision that "if at any time any dispute, difference, or question should arise between the defendants and the plaintiff touching their or his rights or liabilities under the agreement or otherwise ... it should be referred to the President for the time being of the Institute of Civil Engineers, or to such other person as they

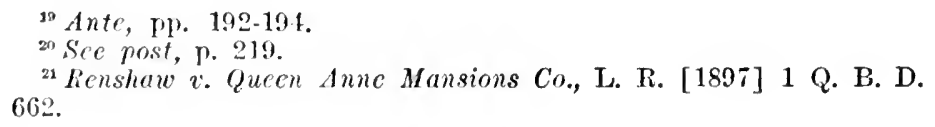

${ }^{21}$ Renshaw $v$. Queen Anne Mansions Co., L. R. [1897] 1 Q. B. D. 
should agree on as sole arbitrator. ..." Although this is on all fours with Davis ". Starr ${ }^{22}$ and should have been controlled by it, Lord Esher attempts to distingruish the eases, asserting "that the defendant there was not ready and willing to submit the whole matter to arbitration, but was only ready and willing to refer the assessment of damages." IIe observes:

"I eannot see any ground for the contention that by the dismissal of the plaintiff the whole contract was put an end to so as to be no longer existing. The question was whether the dismissal of the plaintiff was a breach of the contract by the defendants, and, by virtue of the provision for reference of any dispute to arbitration contained in the contract, I think the judge had power to make the order (of stay)....", ${ }^{23}$ Chitty, J., eoneurs: "As I read the case (of Davis v. Starr), the view on which the Court really aeted was that the defendant was only ready and willing to refer some part of the dispute, and not the whole." 24

But in Davis v. Starr it is clear that the court rested its deeision upon two grounds, one of which was, that the plaintiff's dismissal of the defendant put the whole eontract into question.

In the last decade of the century, we find that under a general provision in artieles of eopartnership for arbitration of all matters in differenee between them an arbitrator has power even to award a dissolution of the partnership..$^{25}$

In Belcher v. Roedean School Site and Buildings Lim-

${ }^{23}$ L. R. 41 Ch. D. 242.

${ }^{23}$ Italics ours.

${ }^{24}$ Italies ours.

${ }^{25}$ Walmsley $v$. White, 40 W. R. 675 (1892), reversing Joplin v. Postlethwaite, 61 L. T. R. 629 and following Fussell v. Russell, L. R. 14 Ch. D. 471, 28 W. R. Dig. 154; Vawdrey v. Simpson (1895), per Chitty, J., 65 L. J. (Ch.) 369, L. R. [1896] 1 Ch. 167, 44 W. R. 123 ; Belfield $v$. Bourne (1894), 8 R. 61 (1894), L. R. [1894] 1 Ch. 521, 6.3 L. J. (Ch.) 104. 
ited ${ }^{2 e}$ decided in the Court of Appeal, the arbitrator is the architect for one of the parties. Collins, MIR., says: "It is nothing unusual for the parties to a building contract knowingly to submit their differences to an arbitrator who is not, and is not expected to be, absolutely unbiassed. In these cases. where the builders dispute what the architect has done, they will ex hypothesi think that the arehitect is in the wrong, and, perhaps, so grossly wrong, as to be even fraudulent. But is the mere fact of sueh a dispute to be allowed to rescind the terms of the agreement, and oust the jurisdiction of the architect, the arbitrator agreed on by the pariies? Certainly not." 27 Now, observe, it is the jurisdiction of the arbitrator which is not to be ousted by the courts. "Can one of two parties, by making the most injurious charges against the arbitrator, charges which in this ease ... are founded on very scanty materials, at once oust his jurisdiction?', 28 "To hold that," says the Master of the Rolls, "would open a wide door for all sorts of attempts to get rid of arbitrators deliberately chosen by the parties to contracts, and to avoid stipulations for the prompt decision of disputes by named persons chosen beeause they are instructed and informed, on whose decision one party is entitled to insist, and to whose decision the other is bound to submit, unless he ean show some real bias on the part of the arbitrator which was not contemplated when he was chosen."

So also in 1893, in Jackson v. Barry Railway Co. ${ }^{29}$ Lord Chancellor Bowen had said: "It is no part of our duty to approach such curiously-coloured contracts with a desire to upset them or to emancipate the contractor from the burden of a stipulation which, however onerous, it was worth his while to agree to bear. To do so, would be to

2085 I. T. R. 468 (1901).

${ }^{n}$ Ibid., p. 471. Italies ours.

2 Italics ours.

${ }^{*}$ L. R. [1893] 1 Ch. D. 238, at p. 247. 
attempt to dietate to the commereial world the conditions under which it should earry on its business."

In 1902, in the Iouse of Lords, in Spurrier ct al. v. La Cloche, ${ }^{30}$ a Jersey fire policy eontained an arbitration clause. The Court held that whether it were treated as an English eontract or as a Jersey eontract the arbitration elause was valid. "That the intention of the parties to a contraet is the true eriterion by which to determine by what law it is to be governed is too clear for eontroversy" (eiting Hamlyn \& Co. v. Talisker Distillery Co.) but in Jersey as well as in England, Scott $v$. Avery is now controlling and the Court repeats with approval the observation of Maule, J., to which we have already referred, "There is no decision which prevents two persons from agreeing that a sum of money shall be payable on a contingeney; but they cannot legally agree that when it is payable no action shall be maintained for it."

In $1903,{ }^{31}$ there eomes up a policy of insurance which provides that "all the parties interested expressly agree to submit to the jurisdiction of the Courts having jurisdiction in such matters of Budapest." It is held in King's Beneh that this was a submission to arbitration, binding upon the courts of England, following Law v. Garrett and Hamlyn \& Co. v. Talisker Distillery. Romer, L. J., says: "It is not as if the insurance eompany alone merely agreed to submit themselves to the jurisdietion of the Courts at Budapest. Here both the parties to the eontract have mutually agreed to submit. If the parties, instead of agreeing to submit all disputes that might arise under the contraet to the Courts at Budapest, had agreed to submit them to a named arbitrator, there could not possibly be any doubt that the person named was the arbitrator to de-

${ }^{80} 71$ L. J. (P. C.) 101; L. R. [1902] A. C. 446 ; 86 L. T. R. 631; 51 W. R. $1 ; 18$ T. L. R. 606.

${ }^{31}$ Austrian-LIoyd Steamship Co. ${ }^{\prime}$. Gresham Life Assurance Society, Lim., 72 I. J. (K. B.) 211. 
cide any disputes. I think the meaning here is the same." 32 The courts of England thus permit themselves to be ousted of jurisdiction by the agreement of the parties, even by the courts of Austria-Hungary.

In 1907, in Gaw $v$. British Law Fire Insurance Co., ${ }^{33}$ Scott $v$. Avery comes up once more for interpretation. The case illustrates markedly with what persistenee the doctrine of revocability fights for its life and how, somewhere and somehow, it regains a footing. Here the insurance company argued that a claim nuder a policy of insurance was fraudulent. The plaintiff insisted that this issue, like any other, should go to arbitration under the covenant to submit all differences to arbitration. Mr. Justice Ross, in the court below, quotes and follows Mr. Justice Coleridge's argument in Scott $v$. Avery: "The Courts will not enforce or sanction an agreement which deprives the subject of that resource to their jurisdiction, which has been considered a right inalienable even by the concurrent will of the parties" and says: "The right to meet a charge of fraud before the King's public tribunals is a right that no man ean part with against his will." Judge Ross refused to apply Scott $v$. Avery, saying, "While the decision of Srott $v$. Avery is accepted by all Courts, the language of Lord Campbell,' in his judgment, "goes mueh further than was neeessary, and has given rise to a good deal of misconception and confusion. It is calculated to ereate an impression that where an agreement to refer all differences exists, accompanied by words indicating that an award is a condition precedent to legal procesdings, a party can be foreed before the private tribunal, no matter what the nature of the differences may be." But on appeal, Iolmes, L. J., writing the opinion, says (eoneerning Scott $v$. Avery): "It will not be denied that that decision legalizes a stipulation in

${ }_{22}$ Italias ours.

:39 [1908] I I. R. 24.5. 
a contract that any difference as to the amount of liability thereunder is to be referred to arbitration, and that no action can be maintained until the amount is so settled, and then only for such sum as shall be awarded. Speaking for myself, however," says he, "I have always been of opinion that Scott v. Avery went farther than this, and is an authority that a contract may legally provide that where a difference ariscs thereundcr rclating to other niatters than amount, no liability is to arise, and no action is to be maintained until the matter of difference has been made the subject of arbitration and award. This," says the learned judge, "has been not only my opinion, but is, I think, the view generally taken by lawyers during the last forty years." ${ }_{34}$ He quotes Martin, B., in Tredwon $v$. Holman ${ }^{35}$ and disapproves of Brett's dictum in Edwards $v$. Aberayron Mutual Ship Ins. Society. He says: "Lord Esher, then Brett, J., distinctly, and Kelly, C. B., with more doubt, took the narrow view of Scott $v$. Avery on which Mr. Justice Ross has acted. It must, however, be remembered that in doing so they not only differed from the majority of the Exchequer Chamber, but from the three judges of the King's Bench. The Aberayron Case has, as far as I am aware, been only referred to in one subsequent English case, Trainor v. The Fire Insurance Co., ${ }^{36}$ in which Lord Esher's view of the effect of Scott $v$. Avery was dissented from; and in Scott $v$. Mcrcantile Acc. \& Guarantee Ins. Co. Limited (see our referenee supra) Lord Esher himself gave a judgment absolutely inconsistent with his dicta in the Aberayron case." Lord Justice Holmes then quotes with approval Lord Watson's words in Caledonian Ins. Co. v. Gilmour (which we have quoted at p. 209), regarding the principle of Scott $v$. Avery. Aceordingly, Judge Ross is reversed. The holding

st Italies ours.

${ }^{35}$ Ante, pp. 186-187.

${ }^{\text {so }} 65$ L. T. R. 825. 
is that even an issue of fraud must be left to arbitration. And so Lord Cranworth's interpretation of Scott v. Avery is once more made effeetive.

If we may trust the modern laborers on such works as "Cases cited, distinguished and overruled," we can say with certainty that after 1892 Vynior's Case is not even referred to by an English court.

In 1914 in Admiralty a clause in a bill of lading provided that any dispute concerning the interpretation of the bill of lading was "to be decided in Hamburg according to German law." It is clearly held that this clause must be treated as a submission to arbitration within the meaning of Section 4 of the Arbitration Act, 1889, and that, although a tribunal at Hamburg was not specified, the contract meant that disputes as to its interpretation were to be tried by the competent court in Hamburg and in accordance with the German law. ${ }^{37}$ The Court now says: "In dealing with commercial documents of this kind, effect must be given, if the tcrins of the contract permit it, to the obvious intention and agreement of the parties. I think the parties clearly agreed that disputes under the contract should be dealt with by the German tribunal, and it is right to hold the plaintiffs to their part of the agreement. Moreover, it is probably more convenient and much more inexpensive, as the disputes have to be decided aceording to German law, that they should be determined in the Hamburg court." In this contract the entire clause read: "Any disputes concerning the interpretation of the bill of lading are to be decided in Hamburg according to German law." The Court eites Law v. Garrett (38 L. T. Rep. 3; 8 Ch. Div. 26), Austrian Lloyd Steamship Company $v$. Gresham Life Assurance Society Limited (88 L. T. Rep. 6; (1903) 1 K. B. 249),

The Cap Blanco, 83 L. J. (P.) 23 (1913); 109 L. T. R. 672; 29 T. L. R. 557. Evans, P. Appeal withdrawn. See 83 L. J. (P.) 23. C. A. 


\section{CORRECTION OF A JUDICIAL ERROR જ21}

Logan v. Bank of Scotland (94 L. T. Rep. 153; (1906) 1 K. B. 141), and Kirchner and Co. v. Gruban (99 L. T. Rep. 932 ; (1909) 1 Ch. 413) that such a clause is a submission to arbitration within the meaning of Sect. 4 of the Arbitration Act of 1889. "The tribunal at Hamburg is not specified, but a fair business like reading of the contract means that such disputes are to be tried by the competent court in Hamburg, and in accordance with German law."

But the old error dies hard. In 1912 we find the King's Bench Division, Fletcher Moulton, L. J., saying: ${ }^{38}$ "Very early in the history of arbitration there arose the question whether a party to a contract containing an arbitration elause was precluded thereby from appealing to a Court of law to enforce his rights under the contract. The answer which the Courts gave to this question admits of no doubt. They decided that no provision in a contract which onsted the jurisdiction of the Courts of law could be valid, but that a clause agreeing to refer disputes to arbitration was valid because it did not oust the jurisdiction of the Courts. In other words they decided that the jurisdiction of the Courts to compel a defendant to appear before them, and their jurisdiction to pronounce finally and conclusively on the rights of the parties after due hearing, were left untouched by such a clause . . or even by proceedings having been commenced under such a submission. Neither a general agreement to submit disputes to arbitration, nor the submission of the dispute in question to a particular arbitrator, nor even the pendency of an arbitration thereon, could be pleaded in answer to a claim in an action." ${ }^{39}$ It is inconceivable that an English judge could so misstate the law. It is like Judge Ross's error in Gaw v. British Law Fire Insurance, or Lord Esher's in the Aberayron Case. When one turns to the eases

Doleman \& Sons v. Ossett Corporation, L. R. [1912] 3 K. B. 256.

s9 Italies ours. 
cited by counsel, one is astounded to find neither Halfhide $v$. Fenning, Waters $v$. Taylor, Marcourt $v$. Ramsbottom, Dimsdale $v$. Robertson, nor, in fact, any case later than Smith and Service ${ }^{40}$ (1890), except Pearson \& Son, Ltd. v. Dublin Corp. (L. R. [1907] A. C. 351). Thompson v. Charnock, Hitchell v. Harris and Harris v. Reynolds ${ }^{41}$ are as far back as either counsel or Court cares to go.

In this case the Court refuses to enforee an agreement whereby the defendant's engineer should determine any question that should arise in the course of a work of construction "touching or concerning the works, or relating to quantities, qualities, description, or manner of work done, executed, or to be done and executed by the contractor, or to the quantity and quality of the materials $\& c .$, '-in short, the case is one of the usual architect's or engineer's certificate. The certificate of the engineer is held to be invalid and of no value whatever.

Vaughan Williams, L. J., dissents: "As between the parties the agreement of reference was not revoked by the refusal of the judge at ehambers to grant a stay of the action. It is true that, generally speaking, the obstacles in the way of the arbitrator, if one of the parties refuses to attend, are so great that it is diffieult, and sometimes practically impossible, for the arbitrator to go on with the arbitration; but if the arbitrator gets over these difficulties and goes on and makes his award, I think his award constitutes accord and sober facts."

By 1913, however, we find the Privy Council holding, in an appeal from Canada, that "When an arbitration for any reason becomes abortive, it is the duty of a Court of law, in working out a contract of which sueh an arbitration is part of the praetieal machinery, to supply the defect which has occurred. It is the privilege," note the word, "of a Court in such circumstances and it is its

${ }^{40}$ I. R. 25 Q. B. D. 545.

47 Q. B. 71 . 


\section{CORRECTION OF A JUDICIAL ERROR 223}

duty to come to the assistance of parties by the removal of the impasse and the extrication of their rights." 42 "This rule," says Lord Shaw, delivering the judgment of their Lordships, " $i$ s in truth founded upon the soundest principle" (note that he does not rest it upon Parliamentary legislation), "it is practical in its character, and it furnishes by an appcal to a Court of justice the means of working out and of preventing the defeat of bargains between parties." 43 And now, in the year of our Lord 1913, his Lordship believes: "It is unnecessary to cite authority on the subject, but the judgment of Lord Watson in Hamlyn \& Co. v. Talisker Distillery ${ }^{44}$ (from which we quote at p. 208 ante) might be referred to." The question before the Lords, says his Lordship, "uent in principle to the incapacity of a Court of law to effectuate justice, by itself undertaking a duty to supply a defect which had occurred in the prescribed mode of ascertaining the rights of parties." 45 That was a "long, long way" to go from my Lord Coke in Vynior's Case. It took over three centuries.

The decision does not refer to the Arbitration Act of 1889 ; it flows from the spirit of the Common Law.

In a very recent case (May, 1916), there comes before King's Bench a contract containing the following clause: "Any dispute on the contract to be settled by arbitration in the usual manner, for which purpose it may be made a rule of Court." 46 One of the parties was a firm of cotton-spinners and the other was a firm of chemical manufacturers. Owing to war conditions, a dispute arose concerning the furnishing of a supply of Epsom salts. Under the arbitration clause, the chemical manufacturers named a

${ }^{42}$ Cameron v. Cuddy, L. R. [1914] A. C. 651, at p. 656.

${ }^{43}$ Italies ours.

${ }^{44}$ L. R. [1894] A. C. 202.

${ }^{45}$ L. R. [1914] A. C. 651, at p. 658. Italies ours.

${ }^{*}$ Bright 2 . Gibson, 32 T. I. R. 533. 
Mr. Heap as their arbitrator and delivered a notice to the cotton-spinners calling upon them to name their arbitrator. Upon failure to name another arbitrator, Mr. Heap notified the parties to attend before him and the cotton-spinners refused to attend. Mr. Heap proceeded without them and awarded the chemieal manufacturers all they claimed. Then counsel for the cotton-spinners made application to the Court to set aside the award upon the ground that, the arbitration not having been had in accordance with the Arbitration Act of 1889, it was invalid, inasmuch as under that Act there should have been a reference to a sole arbitrator named by both parties joint$l y$, or, in default of agreement, to an arbitrator appointed by the Court under Section 5 of the Act. "The phrase "in the usual manner," argued Mr. du Pareq, "must mean "in accordance with the law of the land." " On the other hand, the respondents claimed that the phrase meant "according to the custom of our particular trade." Mr. Justice Rowlatt (Rowlatt and Sankey, JJ.) delivers the judgment. The Court refuses to accept the interpretation that "in the usual manner" means as a matter of law, "in accordance with the Arbitration Act, 1889." "The Court did not think that that was so. They thought that the clause referred to 'the habitual form of arbitration adopted in fact." ", 47 The applicants were given opportunity to show what the habitual form was, but their application to set aside the award was denied.

$\Lambda$ ceordingly, the Common Law of England may now be taken to be that when business men insert in a commercial contract a clause that "Any dispute on the contract shall be settled by arbitration in the usual manner," it is not to be arbitrated in accordance with the Arbitration Aet of 1889, even though the words be added "for which

- Italics ours. 


\section{CORRECTION OF A JUDICIAL ERROR 295}

purpose it may be made a rule of Court," but the habit or custom of the trade shall be inquired into, and, when established, the parties will be required to proceed in accordanee with "the habitual form of arbitration adopted in fact." 


\section{CHAPTER XVII}

\section{HOW ENGLISH ERROR WORKED INTO AMERICAN LAW}

IT will be unnecessary to study all the American eases. With the exception of a few brave pioneers who did some original thinking, one State is like another. Like mathematical computations proceeding with erroneous certainty from initial error, they arrive at the same place, as they proceed from Vynior's Case or Kill v. Hollister. To fix the precise point where the court went driving along the wrong highway we need but fix the date of the case and study the eitations. If we see Milne v. Gratrix, King $v$. Joseph, Aston v. George, Thompson v. Charnock, or Mitchell $v$. Harris, stated as "final and conclusive authorities," we need seareh no farther-we shall know the ease at once as a pretender-not a real heir to the throne. Even if Scott v. Avery is cited, we shall need to look farther and learn whether or not the court followed the Bramwell-Esher or the Cranworth-Campbell interpretation of it. But that few American courts have been set upon the right highway we may be certain, for the Bar has not been assiduous to straighten the signposts. "2 M. to Vynior's Cafe" and a rest for luncheon has been an enticing avenue to an easy destination. Of course, the older milestones, Brode v. de Ripple, Browne v. Downing - the cases in Bracton or Statham-these have been so long buried under the moss and ferns that it were almost sacrilege to disturb them. ${ }^{1}$

${ }^{1}$ For a comparison of early Massachusetts cases with the English cases see "Arbitration as a Condition Precedent," Harvard Law Review, Vol. 11, p. 234. 
It will, perhaps, facilitate the study of the American cases if we arrange their English relatives in some line of family connection, according to dates of birth and upon one side or the otlier. Taking any American case we can then at once trace its ancestry, if we but examine its date and refer to the English cases upon which it rests.

By 1872, Scott v. Avery, Tredwen v. Holman and Braunstein v. Accidental Death Ins. Co. had been decided. As we have said, however, these were but one set of sign-

FOR REVOCABILITY

(I609) Vynior's Case

(1670) Hide v. Petit

(1746) Kill v. Hollister

\} $\begin{aligned} & \text { Coke's in- } \\ & \text { fluence }\end{aligned}$

(1743) Wellington v. Mackintosh

( 1793$)$ Mitchell v. Harris

(1799) Thompson v. Charnock

(1806) Milne v. Gratrix

(I8I4) King v. Joseph

(1819) Aston ข. George

(1859) Horton v. Sayer (Exch.)

(1861) Lee v. Page (Ch.V.C.)

(1863) Mills v. Bayley

(1867) Elliott v. Royal Exch. Ass. Co. (Exch.)

(1870) Thomson v. Ander. son (Ch.V.C.)

(1871) Re Rouse and Meyer (C.P.)

(1875) Edwards v. Aberayron Mutual Ship Ins. Soc. (Exch.Ch.)

(I876) Randall v. Thompson (Q.B.D.)

(1876) Dawson v. Fitzgerald (Exch.Div.)

(I883) Fraser o. Ehrens-

(I889) Davis v. Starr (C. of A.)

(1890) In re Smith \& Service and Nelson \&5 Sons (Q.B.D.)

\section{Against Revocability}

Lord Ken-
yon Eldon's de- ( (1807-8) Waters v. Taylor cisions $\left\{\begin{array}{c}\text { (1820) Harcourt } \\ \text { bottom }\end{array}\right.$ Coke-Hardwicke influence

ColeridgeBramwellBrett influence

Sugden following Elsions and Halfhidev. Fenning don's deci- (1840) Dimsdale o. Robert-

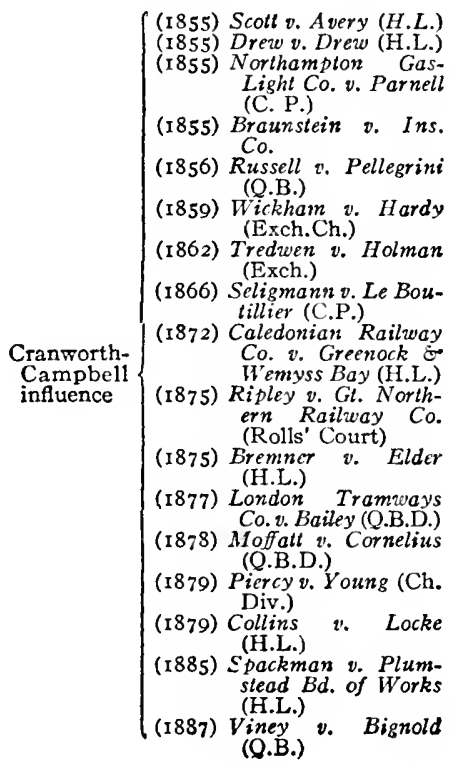


Finally

Herschell-Watson-Coleridge

(1892) Caledonian Ins. Co. v. Gilmour (H.L.)

(1892) Trainor v. Phoenix Fire Ass. Co. (Q.B.)

(I892) Scoll v. Mercantile Ins. Co. (C.A.)

(1894) Hamlyn ". Talisker Distillery (H.L.)

(1897) Renshaw y. Queen Anne Marsions Co. (Q.B.)

Later Cases

(1901) Belcher v. Roebean School Site and Buildings, Lid.

(1902) Spurrier v. La Cloche (H. of L.)

(1903) Austrian-Llovd Steamship Co. v. Gresham Life Ass. Soc. (K.B.)

(1907) Gaw v. Brilish Law Fire Ins. Co. (Irish C. of A.)

(1914) The Cap Blanco (Admiralty)

(19I4) Cameron o. Cuddy (H.L.)

posts. Horton $v$. Sayer and Mills $v$. Bayley were another. In 1872 the New York Court of Appeals had the question of revocability before it in Pres't, ctc., $D$. \& $H$. Canal Co. $v$. Pa. Coal Co., in 50 N. Y. 250. Judge Allen, writing for the Court of Appeals, accepts the Tredwen $v$. Holman-Braunstein $v$. Ins. Co. interpretation-but the case itself requires him to go no farther than the earlier Coleridge-Bramwell interpretation of Scott $v$. Avery. His observations, however, are of the utmost importance in indicating the reluctance with which the New York Courts accepted the old rule. Judge Allen writes with vigor:

"But when the parties stand upon an equal footing, and intelligently and deliberately, in making their executory contracts, provide for an amicable adjustment of any difference that may arise, either by arbitration or otherwise, it is not easy to assign at this day any good leason why the contract should not stand, and the parties made to abide by it, and the judgment of the tribunal of their choice. Were the question res nova, I apprehend that a party would not now be permitted, in the absence of fraud or some peculiar circumstances entitling him to relief, to repudiate his agrecment to submit to arbitration, and seek a remedy at law, when his adversary had not refused to arbitrate, or in any way obstructed or hindered the arbitration agreed upon." 2

${ }^{2} 50 \mathrm{~N}$, Y. 250, at p. 258 . Italics ours. 
"'Ir. Justice Crowder," says Judge Allen, " "in making response to the question propounded by the lords to the judges, in Scott v. Avery, thus states the question and the answer to it: 'Can a shipowner and an insurer enter into a valid agreement that the shipowuer shall pay down a given sum, and that in eonsideration of such payment the insurer upon the loss of a given ship shall pay to the said owner, not the amount of the loss sustained by her through the perils of the sea, but only such sum of money as shall be settled and aseertained by arbitration. I am not aware of any legal objection to such a coutract, whatever may be thought of its prudence. And I think the effect of such a contraet is, that no action lies for the breach of it, until the same has been ascertained by arbitration.' The judge," says Judge Allen further, "lays no stress upon the form of the contraet, but regards the provision for determining the amount to be paid by arbitration as in legal effect postponing the right of action until after the award is made."

Judge Allen's examination of the English cases led him to conclude that "It is not necessary that it should be put in the technieal form of a 'eoudition precedent,' and the courts will give effect to the real intention of the parties, as clearly indicated by the agreement." 4 And in referring to the Braunstein ease, he calls attention to the fact that in that case "the policy did not, in terms, deelare that the award of arbitrators should be a condition precedent to the bringing of an action." 5 On the contrary, as he points out," the covenant was "to the effect that, in case of difference of opinion as to the amount of compensation, the question should be referred to arbitration, and the award made should be taken as a full

Ibid., p. 268.

- Ibid., citing American note to Braunstein v. Accidental Deativ Ins. Co., 101 English Com. Law R., 783.

'Ibid., p. 269. Italies ours. 
settlcment of the question." Our highest court in this day (1872) is inclined to treat the revocation of an arbitration agreement as a failure "to give effect to contracts, when lauful in themselves, according to their terms and the intent of the parties." " Thus it accepts the doctrine laid down by Lord Eldon in Waters $v$. Taylor and IIarcourt $v$. Ramsbottom. "Any departure from this principle," ' says Judge Allen, "is an anomaly in the law," not to be extended. Nevertheless, says he, "the rule that a general covenant to submit any differences that may arise in the performance of a contract, or under an executory agreement, is a nullity," note the word "is too uell established to be now questioned."'s At this point Judge Allen missed the right road. The fact is that the doctrine uas being questioned in England and a settlement of the controversy was not had until twenty years after Judge Allen wrote. Nevertheless, the case before him, as Judge Allen himself says, did not require determination of this specific controversy- "the decision of the appeal of the present defendant does not make it necessary to inquire into the reasons of the rule, or question its existence.", 9

So, in New York, our highest court had traveled this far by 1872 :

1. The annulment of covenants to arbitrate is an anomaly in the law.

2. The soundness of the rule is doubtful.

3. If it were not for its binding force as a precedent, it would not be followed.

4. It need not be questioned at this time. The court accepts, for the purpose of the case, the Coleridge-Bramwell interpretation of Scott $v$. Avery.

-50 N. Y. 250, at pp. 258-259. Italics ours.

${ }^{7}$ Ibid., 1. 2.59. Italies ours.

${ }^{8}$ Ibid., p. 258. Italies ours.

"Ibid. Italies ours. 


\section{ENGLISH ERROR IN AMERICAN LAW 231}

Judge Allen refers at p. 268 to Braunstein v. Accidental Death Ins. Co., as reported in 101 Eng. Com. Law Reports (with American notes). The "American notes" are by Henry Wharton of Philadelphia and appeared in 1863. It will pay us to consider them for a moment. The editor says (p. 799):

"In the earlier decisions it was laid down as an absolute and unqualified rule of law, that a mere agreement to refer disputes arising out of a particular contract to arbitration, was no bar to an action; for it was said such an agreement was contrary to public policy, as tending to oust the jurisdiction of the court" (citing early cases).

"It is not necessary," he says, "to attribute, as has been sometimes done, to the judges by whom this rule was first established, any selfish motive, such as a love of power, or a fear of losing the emoluments of office. The rule had within certain limits a sound basis." Here we have an American explanation: "It is not wise or right in general to sanction contracts by which men through ignorance, folly, or pressure, deprive themselves of the protection which the law affords them. On the whole it is better to guarantee that protection to all, though some at times may not understand its importance.

"Still," he says, "in modern times, the expense and loss of time always incident to litigation, and in certain classes of cases the known prejudices of juries, constantly induce persons to propose and assent to agreements for reference of possible disputes to arbitration."

But if this be so, how are the generally weak or foolish to be protected? may be asked. "This, when the parties stand on equal terms, is reasonable in itself, and leaves it still open to the courts to decide whether any particular case falls within the agreement; to compel or dispense. with a reference when it is wrongfully refused or evaded by one of the parties; and to enforce the auard when 
2roperly made." "And," says he further (this was written in 1863, long prior to the House of Lords' decisions in Mamlyn $v$. Talisker Distillery and the later cases) "when the parties do not stand on equal terms, the aid of a Court of Equity can aluays be had, as in any other case of contract."

Accordingly, Wharton finds "the tendency of the more recent decisions" to be "to give effect to such agreements, under the qualifications just suggested; at least where the reference is expressly made a condition precedent to the right to sue." "Perhaps, indeed," says he, "when the modern theory on the subject comes to be fully worked. out, it will not be considered necessary that the agreement to refer should be put in the strict technical form of a 'condition precedent,' but the real intention of the parties will be rather considered."

The "modern theory" has now been worked out in England. In that country today it is assumed that when parties agree to arbitrate, their intention is not to sue until the arbitration has been had.

In his argument to sustain the arbitration in $D \& H$. Canal Co. v. Pa. Coal Co., Mr. Southmayd ${ }^{10}$ referred to "the old rule of law which we found in the English books, and which we have all learned as law students-that an agreement, for submission to arbitration, of a cause of action cognizable in the Courts of law or equity, is not plcadable in bar to a suit brought upon such cause of action." 'Though this doctrine "was established in the English courts a long time ago" and "was at a time when those courts were struggling for the enlargement of their jurisdiction and when they were all greatly disinclined to assent to anything which would have the effect to abridge either the particular jurisdiction of themselves or the jurisdiction of all the courts" - this learned lawyer was content to accept as binding law the proposition "that

${ }^{10} \mathrm{P} .2$ of his printed argument. 
the attempt of parties to substitute a tribunal constituted by themselves, for the decision of a question which, by the law of the land, is cognizable by the courts of the country, is against public policy."

Yet he could not harmonize this doctrine with the rule that a counter-suit could be maintained for breach of the agreement to arbitrate, nor could he understand why, since "the object of an agreement to arbitrate is to avoid litigation," you should give such a construction to the agreement as would really give the party "the luxury of having two law-suits in lieu of one." Said he, "It is difficult to perceive that you make any approach to earrying out the purpose for which the contract was made."

And he found, also, that this original doctrine had come to be doubted by the English judges-even Lord Kenyon having come "seriously to doubt whether it really rested upon any very solid ground of principle, and to doubt whether the original establishment of the rule was sound or wise."

"Nevertheless, they said the rule was established firmly in the law, and whatever might be the opinion of the courts in regard to its wisdom or soundness, it must be accepted as a part of the established law of the land." And so he concedes the whole point.

This, Mr. Southmayd believed, was Lord Kenyon's conclusion in Thompson v. Charnock and he dug no farther. He did not discuss Dinsdale v. Robertson, where, in 1840, Lord Sugden pointed out that Lord Kenyon's views in Halfhide $v$. Fenning were still the law of England. Like Bramwell in England, Southmayd, in New York, fastens the limitcd and narrow construction of the law upon our Common Law. His whole argument is confined to the "condition precedent" theory and does not venture into original sources. He is obliged to admit that the doctrine was in England "now upheld purely on the principle of stare decisis"; and he asserts that "if at any time 
within the last fifty ycars the question would have been presented as a new one to the courts, no such doctrine would have been established.' Like Bramwell, however, he could win his case by conceding the unsound rulc and arguing for its qualification: 'This he succeeds in doing. ${ }^{11}$

If, however, Mr. Southmayd had made a careful historical analysis of the English cases, is there any doubt that he could have induced Judge Allen to reject Thompson $v$. Charnock as stare decisis?

Three years later (1875) Chief Justice Andrews writes (Fudickar v. Guardian Mutual Life Ins. Co.) :12

"It is the general doctrine pervading our jurisprudence on the subject, that the decision of an arbitrator in a matter within his jurisdiction is final and conclusive between the parties. The jealousy with which, at one time, courts regarded the uithdrawal of controversies from their jurisdiction by the agreement of parties, has yielded to a more sensible vicw, and arbitrations are now encouraged as an easy, expeditious and inexpensive method of settling disputes, and as tending to prevent litigation."

The agency theory underlying Coke's dictum in Vynior's Case is nowhere more clearly disposed of than by Judge Andrews' definition of an arbitrator. He, said Judge Andrews, is "a judge appointed by the parties; he is by their conscnt invested with judicial functions in the particular ease; he is to determine the right as between the parties in respect to the matter submitted, and all questions of

"Franeis Lynde Stetson, ex-president of The Association of the Bar of the City of New York and one of the learlers of the New York Bar, diseussing the report of the Committee on Prevention of Unneecssary Litigation at the 1917 meeting of the New York State Bar Association, said: "... the decision originally in this State and in the Delaware of Hudson Case and the Pennsylvania Coal Company Case was a Ireadful blow to peace and contrary to the spirit of the Constitution then prevailing, the Constitution of 1846, which provided specially for tribunals of conciliation." (Reports, Now York State Bar Association, Vol. XL, 1917, p. 404.)

${ }^{12} 62$ N. Y. 392 , at p. 339. Italics ours. 
fact or law upon which the right depends are, under a general submission, deemed to be referred to him for decision. ... If courts should assume to rejudge the decision of arbitrators upon the merits, the value of this method of settling controversies would be destroyed, and an award instead of being a final determination of a controversy would become but one of the steps in its progress." 13

In 1877 the New York Court of Appeals said: "We are not at liberty to be hypercritical for the purpose of overturning the decisions of these domestic tribunals, and compelling a resort to the courts of justice. It would be better for the people if more of their controversies should be settled in the same way, and justice would be quite as likely to be done as when administered by the more formal methods of litigation in the courts. A liberal interpretation should be given to the submission, and the award made, to uphold the latter when it is not attacked for corruption or misconduct of the arbitrator." 14

Forty years later than the $D$. \& H. Case (Welch $v$. Probst $)^{15}$ the Appellate Division of the Fourth Department upholds the practice of arbitration "in the light of the custom which prevailed in New York City." Where there was but a most informal interchange of letters it adopted the course of the trade for creating arbitration, saying:

"It is the policy of the courts to encourage and uphold arbitrations, as they are an inexpensive, simple and expeditious method of adjusting controversies, and tend to prevent litigation." 16

In the D. \& H. Canal Co. v. Pennsylvania Coal Co. Case, Judge Allen cites three New York cases. These we

Ibid., pp. $399,400$.

${ }^{14}$ Curtis v. Gokey, 68 N. Y. 300, at p. 305.

${ }^{16} 151$ App. Div. 147 (1912).

${ }^{10}$ Ibid., p. 151 . Italies ours. 
shall now briefly eonsider. The first is Wood $v$. Lafayette ${ }^{17}$ in 1871 (Judge Grover writing the opinion). Here the Court held flatly that an agreement to submit an existing controversy to arbitration was revoeable. It cites 110 authority for its conclusion, merely saying: By an agreement the matter of a boundary line "the parties agreed to submit to Mann, and to abide by his decision. This was the only matter with whieh he had anything to do; everything else was settled by the agreement. In determining where the line was, Mann was to act as arbitrator; his power so to act was revocable by either party, as is the case in every submission to arbitrators, if exercised at the proper time." Even the faet that it was part of an agreement to settle an existing suit made no difference. "The fact that there was a consideration for the agreement, in the settlement of the existing suit, makes no difference in this respect. Every agreement to arbitrate must, to be valid, be based upon a consideration. .. The agreement to submit the question to Mann was the only part revocable by either party ; his power having been revoked, his subsequent determination was not binding upon the parties." It is diffieult to follow this reasoning. The parties are held to their entire contract save the one feature which is to keep them from further litigation. Though this feature was in their minds an essential element in the making of the contract, either one may keep the rest of the eontract and eancel the portion providing for arbitration however unjust a result might thus be produced.

The seeond New York ease cited by Judge Allen is Smith $v$. Compton, ${ }^{18}$ in 1855, decided by the Supreme Court of Cayuga County (T. R. Strong, J.) holding that "An agreement of submission of matters in differenee to arbitrators, followed by the arbitrators entering upon

${ }^{17}$ Wood $v$. Iafayette, 46 N. Y. 484, at p. 489.490. Italics ours. "20 Parb. 262, at p. 267. 
their duties-the arbitration being still pending and undetermined-constitutes no defense, or legal obstacle, in abatement or in bar, to an action for the same matters, commenced after the making of the agreement. Such an agreement is a mere authority, revocable by either party, at any time before the ease is finally submitted to the arbitrators for decision, subject only to liability for damages." Counsel for neither of the parties referred-so far as the report shows-to any of the English cases, and the Court relied entirely on Story's Eq. Juris. §1457, and "cases there cited," saying: "The principle is well settled, that a specific performance of an agreement to refer a subject of controversy, will not be enforced by the courts, on the ground that it is against public policy thereby to exclude parties from a resort to the proper judicial tribunals."

The third case cited by Judge Allen is Haggart v. Mor$\operatorname{gan}^{19}$ (1851), wherein the Court of Appeals (Gardiner, J.) held that "the agreement to arbitrate, only entitled the party to damages, but was no bar to an action," eiting for this Mitchell $v$. Harris, ${ }^{20}$ whose lack of binding force as an English precedent has been clearly demonstrated, ${ }^{21}$ and 2 Story's Eq. Jur. $\S \S 1457-8$, which we shall consider later. ${ }^{22}$ In this case the arbitration clause under consideration was part of a building contract and was limited to "any dispute which should arise respecting the work or finish of the building." The case discloses a complete absence of research or study of the English precedents. We turn now to more recent cases.

In Benson v. Eastern Building and Loan Association ${ }^{23}$ decided in 1903, there was a provision in certain building loan certificates that "any action brought against this

${ }^{19} 5$ N. Y. (1 Seld.) 422.

${ }^{20} 2$ Ves. Jr. 129, Sumner's Ed. and note.

"See ante, pp. 153-159.

See post, pp. 250-252.

${ }^{28} 174 \mathrm{~N} . \mathrm{Y} .83$, at p. 86, 87. Italies ours. 
association (defendant) shall be commenced within six months after filing proofs and in the county of Onondaga and state of New York." The Court of Appeals holds this valid and says that "If in violation of the stipulation the plaintiff brought his action in another county, the defendant's remedy was to move to have the place of trial changed to that in which the plaintiff had agreed it should be brought. . . . The erroneous practice neither affects the jurisdiction of the court nor defeats the cause of action.'" But the Court sees clearly the logical effect of the argument that this provision in the contract attached a coudition to the contract. Discussing the argument that "the parties have agreed that the shareholder" should have no cause of action against the defendant unless his action was brought in the specified county in the state of New York, and that, therefore, when he brings a suit elsewhere, his cause of action is not established," "We think," says Judge Cullen, "this argument proves too much. It is difficult to see uhy it would not uphold an agreement that all claims against the parties should be determined by arbitrators and not by the courts. It might be said with as much force in such a case as in the one now before us that the cause of action could, under the agreement, accrue only on the decision of the arbitrators." Yes, this is thoroughly sound reasoning, as the English judges finally decided. "Yet,"' says Judge Cullen, "nothing is better settled than that agreements of the character mentioned are void." And for this he cites the D. \& H. Canal Company Case, which, as we have seen, is no authority at all for the proposition.

Thus is unsound decision rested upon unsound decision and erroneous doctrine piled upon erroneous doctrine.

In April, 1895, the case of Sanford $v$. Commercial Travelers' Assn. ${ }^{24}$ came before the Appellate Division of the Fourth Department. Upon appeal the Court of Appeals

^s 86 Hun 380. 


\section{ENGLISH ERROR IN AMERICAN LAIV 239}

followed the court below ${ }^{25}$ in holding invalid a clause which provided that "the issues in any action brought against it (the defendant) under this certificate, shall, on the demand of this association or its attorney, be referred for trial to a referee to be appointed by the court in which such action is brought." Here, obviously, was no ouster of jurisdiction of the courts, merely a waiver of trial by jury and consent in advance to a referee to be named by the court. Yet this fear of "ouster" was so terrifying that even a clause such as this one was held to be invalid, the Court of Appeals relying upon the opinion of the Appellate Division below. When, however, we turn to the opinion of the Court below, we find (as we might expect to find), that reliance is placed upon the English cases of Kill v. Hollister, Mitchell v. Harris, Thompson $v$. Charnock, Street v. Rigby, Scott v. Avery, Horton v. Sayer, Roper $v$. Lendon and the whole line of now discredited English precedents. The really authoritative and controlling line of Halfhide v. Fenning, Waters $v$. Taylor, Harcourt v. Ramsbottom, Dimsdale v. Robertson, Drew v. Drew and the later cases (1872-1894, especially Trainor $v$. Phoenix Fire Ins. Co., Scott v. Mercantile Ins. Co. and Hamlyn v. Talisker Distillery) are not even referred to. American cases in other states and Federal cases resting upon the obsolete English authorities are piled upon each other till they make a fastness seemingly too formidable to attack.

Greason v. Keteltas, ${ }^{26}$ in the Court of Appeals in 1858 (Selden, J.), rests upon Mitchell v. Harris, 2 Ves. Jr. 129, notes 3, 4, Sumn. ed. "So scrupulously," says the Court, "is this right of revocation guarded, that it is not lost, although the submission has been actually made a rule of court." Waters $v$. Tayior, Harcourt v. Ramsbottom,

25 147 N. Y. 326.

so 17 N. Y. 491. 
Dimsdale v. Robertson-all later and more authoritative -are not even cited by the Court.

Thus in the New York, as in the earlier English law, specific performance of an agreement to arbitrate is not allowed. The courts oust themselves of jurisdietion to enforee the contract of the parties.

The "right of revocation" is "the policy of the law" says Judge Selden, and is founded "in the obvious importance of securing fairness and impartiality in every judicial tribunal. Arbitrators being selected, not by law, but by the parties themselves, there is danger of some seeret interest, prejudice or bias in favor of the party making the selection; and hence the opposite party is allowed, to the latest moment, to make inquiries on the subject." Yet our Code permits parties to select their own referees and even their own arbitrators.

Perhaps the most modern statement of what we have here treated as error is the one in Sanford $v$. Accident Association $^{27}$ (1895), in which Judge Gray holds invalid an agreement in a policy that in case suit be brought it shall "be referred for trial to a referee to be appointed by the court." He says: "We may safely base the reason for the application of this rule upon the proposition that public policy is opposed to the enforeement of an agreement, which supersedes the law and deprives the individual of the protection which it was designed and framed to afford" and this "protection" is "the constitutional provision which secures to a party the right of trial by jury."

The right of trial by jury is one that ean be waived. The right to bring suit at all can be waived. The parties may waive it by agreement to forbear from bringing suit, or, after suit, by stipulating in open court to discontinue. They may even consent to the entry of judgment. By so doing, of course, they set aside and supersede the opera-

${ }^{27} 1.17 \mathrm{~N}$. Y. 8296 , at p. $: 208,399$. Ttalies ours. 


\section{ENGLISH ERROR IN AMERICAN LAW 241}

tion of the law and "the protection which it was designed and framed to afford." Yet it is not against public policy. ${ }^{28}$ In the case of The Oranmore, ${ }^{29}$ the parties stipulated that "Any questions arising under this contract or the bill of lading against the steamer or her owners shall be determined by English law in England." The Court held that this was valid and that "the court should give effect to this clause of the agreement. It leaves the intention of the parties beyond doubt of any kind, and that intention was to give to the provisions of the bill of lading such efficacy as the English courts would give to them."

${ }^{23}$ See also McAllister v. Smith, 17 Ill. 328, 334; Dike v. Erie Railway Co., 45 N. Y. 113, 116; Grand v. Livingston, 4 App. Div. 589, 593; Union National Bank v. Chapman, 169 N. Y. 538, 545; Le Breton v. Miles, 8 Paige 261.

${ }^{20} 24$ Fed. Rep. 922. 


\section{CHAPTER XVIII}

\section{THE DEVELOPMENT IN THE FEDERAL (U. S.) COURTS}

Is the introduction ${ }^{1}$ we referred to the decision by Judge Hough in United States Asphalt Refining Co. v. Trinidad Lake Petroleum Co. ${ }^{2}$ as the incident which set in motion the protests of the London Court of Arbitration to the New York Chamber of Commerce. We are now ready to study Judge Hough's opinion more in detail. First of all, the learned judge clearly indicates his lack of sympathy with the rule. For "refusing to give effect to the agreements of men of mature age, and presumably sound judgment," says he, "there has long been a great variety of available reasons." These agreements have, he believes, "the intended effect . . . to prevent proceedings in any and all courts and substitute therefor the decision of arbitrators." The plaintiff's action in refusing to carry out the provision for arbitration ${ }^{3}$ he aptly describes as "this libelant's contract breaking" and this leads him "to consider at some length the nature and history of the reasons adduced to justify the sort of conduct, by no means new, but remarkably well illustrated" in the case before him.

${ }^{I}$ Pp. ix, $\mathbf{x}$.

2222 Fed. Rep. 1006.

"19. Any dispute arising under this eharter shall be settled in London by arbitration, the owners and charterers each appointing an arbitrator, and the two so chosen, if they do not agree, shall appoint an umpire, the decision of whom shall be final. Should either party refuse or neglect to appoint an arbitrator within 21 days of being required to do so by the other party, the arbitrator appointed may make a final decision alone, and this decision shall be binding upon both parties. For the purpose of enforcing any award, this agreement shall be made a rule of court.', 
First of all, he quotes from Lord Campbell in Scott $v$. Avery "_ "in the contests of the courts of ancient times for extension of jurisdiction-all of them being opposed to anything that would altogether deprive every one of them of jurisdiction" and says that it "has never been denied that the hostility of English-speaking courts to arbitration contracts probably originated," as Lord Campbell said it did. "A more unworthy genesis," says Judge Hough, "cannot be imagined."

Since Lord Kenyon's time (Thompson v. Charnock ${ }^{5}$ ), "it has been customary to stand rather upon the antiquity of the rule than upon its excellence or reason" and there is "little difference," he believes, "between Lord Kenyon's remark" in this regard and the words of Judge Cardozo in the Meacham case. " "Nevertheless the legal mind must assign some reason in order to decide anything with spiritual quiet" - note the language-and so he proceeds to analyze in order the five reasons (a) the contract is in its nature revocable; (b) such contracts are against public policy; (c) the covenant to refer is but collateral to the main contract, and may be disregarded, leaving the contract keeper to his action for damages for breach of such collateral covenant; (d) any contract tending to wholly oust the courts of jurisdiction violates the spirit of the laws creating the courts, in that it is not competent for private persons either to increase or diminish the statutory juridical power; (e) arbitration may be a condition precedent to suit, and as such valid, if it does not prevent legal action, or seek to determine out of court the general question of liability.

The doctrine of revocability, the judge finds, as we have found, rests upon Vymior's Case "and is now somewhat old-fashioned, although it appears," with due cita-

5 H. L. C. 811.

$\circ 8$ T. R. 139.

- Meacham v. Jamestown, etc., R. R. Co., 211 N. Y. 346, at p. 354. 
tions of authorities, in two modern eases to which the judge refers." "The Public Poliey Doctrine," the learned judge finds, as we have found, has no substantial basis in reason; "of late years the higher courts have been somewhat chary of the phrase 'public policy,',' (and he illustrates from Insurance Co. $v$. Norse, Doyle v. Continental Insurance Co., ${ }^{9}$ and Perkins $v$. United States, etc., Co.) 10 "But neither the court (the U. S. Supreme Court) nor the commentator (Story) pointed out any other method by which an arbitration agreement could be against the policy of the law, unless it were by seeking to divest the 'ordinary jurisdiction of the common tribunals of justice.' "This divesting of jurisdiction we have considered so fully in other chapters that we need not here repeat the demonstration of its unsoundness. But, "Having built up the doctrine that any eontraet which involves an 'ouster of jurisdiction' is invalid, the Supreme Court of the United States," says Judge Hough, "has been able of late years to give decision without ever going behind that statement." As in Insurance Co. v. Morse, where it is said: "Agreements in advance to oust the eourts of the jurisdiction eonferred by law are illegal and void." But even Judge Hough fails to go back of tine Federal and State decisions to the scene of original sin-he takes for granted, as did Southmayd in the $D$. \& $M$. Case, that the English authorities remain at least preeedentially authoritative. Taking the federal authorities as they stand, however, he finds "comment... superfluous upon any theory of law (if law be justice) that ean eome to such conclusions." To support the effort of "the eontract breaker who sued when he had promised not to" outrages this judge's sense of equity as it did Lord Eldon's in Waters $v$. Taylor and

'Oregon, etc., Banl v. American, etc., Co. (C. C.), 35 Fed. 22; and Tobey $v$. County of Bristol, 3 Story 800, Fed. Cas. No. 14,065.

${ }^{8} 20$ Wall. 445,22 I. Ed. 365.

- 94 U. S. 535, 24 I. Fd. 148.

${ }^{20}$ (C. C.) 16 Fed. 513. 
Harcourt $v$. Ramsbottom, though, curiously enough, these decisions (like many others which we have reviewed in preceding pages) do not seem to have been brought to the attention of this modern equity judge. In fact, the only English cases to which Judge Hough refers are Thompson v. Charnock (false precedent), Dawson v. Fitzgerald (false precedent), and the modern cases of Hamlyn $v$. Talisker Distillery Co., Manchester Ship Canal Co. v. Pearson \& Son, ${ }^{11}$ and Austrian-Lloyd Co. v. Gresham, etc., Society. ${ }^{12}$ Due to this absence of complete historical analysis of the English cases, Judge Hough falls into the same error as does Mr. Rosenbaum, ${ }^{13}$ in believing that it is the English Arbitration Act of Parliament which "has compelled the courts of that country to abandon the doctrine that it is wrong or wicked to agree to stay away from the courts when disputes arise." Thus he concludes that "It is highly characteristic of lawyers that, when thus coerced by the Legislature, the wisdom of previous decisions begins to be doubted." He quotes from Lord Watson in the Talisker Distillery case: "The rule that a reference to arbitrators not named cannot be enforced does not appear to me to rest on any essential considerations of public policy. Even if an opposite inference were deducible from the authorities by which it was established, the rule has been so largely trenched upon by the legislation of the last 50 years ... that I should hesitate to affirm that the policy upon which it was originally based could now be regarded as of cardinal importance." And he finds that "Neither the Legislature of New York nor the Congress has seen fit thus to modernize the ideas of the judges of their respective jurisdictions." But if Judge Hough had found, as is the fact, that the early English cases were

${ }^{11}$ L. R. [1900] 2 Q. B. 606.

${ }^{12}$ L. R. $[1903] 1$ K. B. 249.

${ }^{18}$ Samuel Rosenbaum: "A Report of Commercial Arbitration in England." Bulletin XII, American Judicature Society. 
not truly authoritative and that it was the English Courts, not the English Parliament, who changed the Common Law of England (though their change of heart, we must admit, was somewhat accelerated by Acts of Parliament) he would surely not have chided Congress or our State legislatures so severely. For since "the question," as he finds it, "is one of remedy, and not of right," no harm could have come through judicial correction of this judicial error. The judicial error itself is nowhere better stated than by Judge Hough himself:

"Whatever form," says he, "of statement the rule takes, the foregoing citations show that it always amounts to the same thing, viz.: The courts will seareely permit any other body of men to even partially perform judicial work, and will never permit the absorption of all the business growing out of disputes over a contract by any body of arbitrators, unless eompelled to such aetion by statute. Even such eases as Mittenthal $v$. Mascagni, 183 Mass. 19, 66 N. E. 425, 60 L.R.A. 812, 97 Am. St. Rep. 404, show no more than a belated acceptance of the right to confine litigation by contract to a partieular court, for even that opinion does not recognize the right of mankind to contract themselves out of all courts."

Finally, the judge is driven to what he regards as the sole question in the case before him: Shall he overrule the United States Supreme Court though he believe it to be elearly in error, or shall he let the United States Supreme Court reverse itself? He has only to deeide, as he sees it, "whether the law as laid down by the Supreme Court of the United States" shall be followed or not. And his answer is this: "It was within the power of that tribunal to make this rule. Inferior courts may fail to find convincing reasons for it; but the rule must be obeyed," and thus, against his will, he is compelled to award judgment to the "eontract-breaker."

This ease, deeided by Judge Hough in 1915, was an 
Admiralty case. Just as the lawyers in that case failed to dig deeply into the sources of the original judicial error, so apparently they failed to bring to Judge Hough's attention the ease of Toledo S. S. Co.v. Zenith Transp. Co., also in Admiralty, decided in 1911, by the Federal Circuit Court of Appeals in the Sixth Circuit. ${ }^{14}$ Here three judges (Warrington, Denison and Hollister) refused to permit the "contract-breaker" to win out. "It is to be gathered from the contract of submission and the subsequent agreements that the parties intended a bona fide determination of the question of fault and, as incidental thereto, the amount of damages the defeated party should pay. What kind of arbitration would it be, if each party, solemnly in writing pledging himself to its terms, could nevertheless destroy it by revocation after the real question in controversy were decided against him? If he could do this once, he could do it on resubmission, and, if on resubmission the question were decided the other way, the then defeated party might revoke. The ethical impropriety of the defeated ouner's revocation," writes Judge Hollister for the Court, "at such a stage in the proceedings is obvious and will not be sanctioned by a court except under the compulsion of rules of law clearly applicable." The Court made a short excursion into the English cases, touching Vynior, Mills v. Bayley and Northampton Gaslight Co. v. Parnell, quoting from the latter Maule's famous paragraph:

"The old rule upon which it was held that the power of an arbitrator was revocable was that a power not coupled with an interest was revocable-revocable by the authority which created it. From that rule it was inferrederroneously, as I think-that one of the parties to a submission might revoke without the other. It seems to me that was allowing one man to affect the interests of another. But it was an inveterate error."

${ }^{14} 184$ Fed. Rep. 391. Italics ours. 
It adopts the reasoning in Harcourt v. Ramsbottom and Pope v. Lord Duncannon, ${ }^{15}$ wherein the Court said: "I say that a Plaintiff is not at liberty to ask the aid of a court of equity in respect of an act done by him against good faith" and as "there is nothing whatever to show that the power which the Plaintiffs had given to the arbitrators was revoked upon any just or reasonable grounds, I am bound to conclude that the revocation was a uanton and capricious exercise of authority on their parts. ...."

Since Courts of Admiralty deal "with causes upon considerations even more clastic than pertain to the broad jurisdiction of Courts of Chancery," this Federal Court refuses to permit the plaintiff to plead his own "unethical conduct" as a basis for relief in Admiralty.

It is true that the ease rests upon several grounds, namely (a) that the submission was not subject to revocation; (b) even if it were subject to revocation, it could not be revoked after the award was published (which was the fact in the case under consideration); and lastly, (c) that in its nature the agreement under review did not constitute "an arbitration under the strict rules of the Common Law." Nevertheless, Judge Hough might well have adopted the reasoning of Judge Hollister in the $Z$ enith Case and treated it as an authoritative decision in Admiralty, for denying relief to him who had done "an unethical thing." "We are brought," says Judge Hollister, "to this conelusion by a number of considerations, the chief of which is that justice and fair dealing between man and man require it." 16

"The appellant invokes the aid of this court to fix the fault of the collision upon the respondent. He sets at naught, as if it never existed, the solemn agreement he made that the question of fault should be decided by ar-

2s $9 \mathrm{Sim} .177$, at pp. 179-180. Italics ours.

20184 Fed. Rep. 391, at p. 395. 
bitration. That question was settled against him by his own tribunal. He would have this eourt declare the arbitration a futility. If it is a futility it is only because he has made it so. He will not, in a court of admiralty, be permitted to take such advantage of his own wrong." ${ }^{17}$

Nor was Judge Hough's attention called to the unpublished decision of his colleague, Judge Ward, in the case of Clark v. Hamburg-American Packet Company, granted April 15, 1913. The deeision is quite short and is worth publishing in full:

"The stipulation in the charter party that all disputes were to be settled by umnamed arbitrators in London was not a provision regulating the remedy incidental to the contract, but was a substantive part of the contract itself. If the charter had been made in New York such a provision would not be valid, Delaware \& Hudson Canal Co. v. Penna. Coal Co., 50 N. Y. 250. But the demurrer admits that the charter was made in Germany between a German corporation and a citizen of the State of New York and that the provision as to arbitration is valid by the law of Germany. The principal dispute is whether the defendant should have supplied a la carte dinners, as distinguished from table d'hôte dinners. If this was a breach of the contract it was a breach committed on the ship, which is a part of German territory and generally while on the high seas. Arbitration of particular controversies is recognized under certain conditions in New York, Code of Civil Proc. Secs. 2365-2386. I think this provision in the contract is a good plea in bar to an action in the courts of this state, Hamlyn v. Talisker (1894) App. Cas. 202. The demurrer is overruled with costs."

Turning now to the leading United States Supreme Court case (Insurance Co. v. Morse, 20 Wall. 445), we find (at p. 451) Mr. Justice Hunt saying:

"There is no doubt of the general principle that parties ${ }^{17}$ Ibid., p. 400 . 
cannot by contract oust the ordinary eourts of their jurisdiction."

This quotation is from Scott $v$. Avery and includes the famous quotation from Thompson $v$. Charnock (Lord Kenyon) "that the fact that the parties had agreed that the matter should be settled by arbitration did not oust the jurisdiction of the eourts."

Here, then, is the source of error in the United States Supreme Court: the erroneous interpretation of Scott $v$. Avery and the treatment of Thompson $v$. Charnock as authoritative-almost the precise error made by the Court of Appeals in $50 \mathrm{~N}$. Y. The decision in Insurance Co. $v$. Morse was rendered in 1874, at a time when the English authorities were still in confusion; but it has been repeatedly cited and followed without attempt to correet the error.

Perhaps no author is more frequently quoted in this country than Story for the erroneous doctrine we are considering. Citing Street v. Rigby, Thompson v. Charnock, Waters $v$. Taylor and Wellington $v$. Mackintosh and ignoring all the other English authorities, he said in his Equity Jurisprudence $(\$ 670)$ that "where the stipulation, though not against the policy of the law, yet is an effort to divest the ordinary jurisdiction of the common tribunals of justice, such as an agreement, in ease of any disputes, to refer the same to arbitrators, Courts of Equity will not, any more than Courts of Law, interfere to enforee that agreement, but thcy will leave the parties to their own good pleasure in regard to such agreements" -a doetrine so unsound as to shock every modern student of equity. Why should a court of equity encourage "contract breakers"? Because, says Judge Story, "The regular administration of justice might be greatly impeded or interfered with by such stipulations if they were specifieally cnforced. And at all events courts of justice are presumed to be better capable of adminis- 
tering and enforcing the real rights of the parties than any mere private arbitrators, as well from their superior knowledge as their superior means of sifting the controversy to the very bottom." It is true that courts of equity may do more exact justice than arbitrators. But why limit its jurisdiction? Why not let equity revise all business contracts? It eould, no doubt, make more equitable bargains than the parties themselves, and certainly would avoid many of the blunders that are made by business men.

Again, he puts it ( $\$ 1457)$ that courts of equity will not enforee the specifie performance of an agreement to arbitrate, "deeming it against publie policy to exclude from the appropriate judieial tribunals of the State any persons who, in the ordinary course of things, have a right to sue there," for which he cites Kill v. Hollister, Mitchell $v$. Harris, and Street v. Rigby-all, as we have seen, reversed and unsound precedents. That these were the sourees of Judge Story's error appears further from a study of Tobey $v$. County of Bristol, decided in $1845^{18}$ (Mass.), wherein he cites all of these cases as well as Thompson $v$. Charnock. "No one can be found, as I believe," said he, "and at all events, no case has been eited by counsel, or has fallen within the scope of my researches, in which an agreement to refer a elaim to arbitration, has ever been specifically enforced in equity. So far as the authorities go, they are altogether the other way." In this, the great and learned author was in error, as he was in his reasoning.

Yet he did not regard such agreements as against public policy. "The argument at the bar misconeeived the doctrine of the Court on this head. Courts of equity do not refuse to interfere to compel a party specifically to perform an agreement to refer to arbitration, because they wish to diseourage arbitrations, as against publie

${ }^{18} 3$ Story's Reports 800. 
policy. On the contrary, they have and can have no just objection to these domestic forums, and will enforce, and promptly interfere to enforce their awards when fairly and lawfully made, without hesitation or question." But a few sentences further on he says: "It is certainly the policy of the Common Law, not to compel men to submit their rights and interests to arbitration, or to enforce agreements for such a purpose. Nay, the Common Law goes further, and even if a submission has been made to arbitrators, who are named, by decd or otherwise, with an express stipulation, that the submission shall be irrevocable, it still is revocable and countermandable, by either party, before the award is actually made, although not afterwards." "'This," says he, "was decided as long ago as in Vynior's Case (8 Co. R. 81, b.). The reason there given, is, that a man cannot, by his act, make such authority, power, or warrant, not countermandable, which is by law, and of its own nature, countermandable"'; etc., etc. So a great Amcrican jurist revives the error of a great English jurist and Story adds to Coke the strength of an illustrious name to a fundamentally unsound doctrine. We are not surprised to find him citing as approved English precedents not only our old friend, Vynior's Case, but Milne v. Gratrix, Clapham v. Higham, and King $v$. Joseph. 


\section{PART THREE-THE SOUNDER DOCTRINE}

\section{CHAPTER XIX}

\section{THE COURT'S JEALOUSY OF ITS OWN JURISDICTION}

IN his study of Commercial Arbitration in England, Mr. Rosenbaum says: "In the early days judges, as well as other court officers, were paid by fees on the volume of business that came to them and being only human they looked with disfavor upon any limitations on their powers. It is easy to appreciate the psychology of the legal maxim: "The office of a good judge is to extend his jurisdiction.",

Support for this view, it is true, is to be found in Lord Campbell's remarks in Scott $v$. Avery, which curiously enough are not to be found in the reports of "House of Lords Cases," 2 but only in 25 I. J. (Exch.) 308, at p. 312 et seq. Evidently the reporter did not care to give additional space to these animadversions. Lord Campbell stated:

"Was such a contract illegal? It was contended to be illegal on the ground of public policy. What pretence was there for that argument? The public could not be injured by such a contract. There could be no injury to the public in an insurance company contracting that no action should be brought against it, the costs of which might be ruinous, but that every dispute should be referred to a domestic tribunal which might speedily and

${ }^{1}$ Bulletin XII, American Judicature Society, at p. 19.

${ }^{2}$ See 5 H. L. C. 811, at p. 851. 
economically determine the dispute. Public policy seemed to him to require that such a contract should be enforced. If there were any decisions the other way, he should ask their Lordships to reverse them as contrary to principle. The doctrine had its origin in the interests of the Judges. There was no disguising the fact that, as formerly, the emoluments of the Judges depended mainly, or almost entircly, upon fees, and as they had no fixed salary there was great competition to get as much as possible of litigation into Westminster IIall, and a great scramble in Westminster Hall for the division of the spoil." And hence the dispute between the different Courts about a latitat, a capias, and a quo minus, the latitat bringing business into the Court of Queen's Bench, the capias into the Court of Common Pleas, and the quo minus into the Court of Exchequer. And they had great jealousy of arbitrations whereby Westminster Hall was robbed of those eases which came not into the King's Bench, nor the Common Pleas, nor the Exchequer. Therefore they said that the Courts ought not to be ousted of their jurisdiction, and that it was contrary to the policy of the law to do so." 4

It is true that the earlier judges of England were paid by fees upon the volume of business transacted, as well as by salary. While during the period from William I to Henry III, the people could have justice administered in the courts of arbitrary and potent lords (i. e. county courts), "It is not remarkable," says Reeves, "5 "that suitors coming to a court under such circumstances should consent to purchase the means of redress by paying a fine. Upon such terms was the euria regis (founded by William the Conqueror) open to all complainants: and the institution

Italies ours.

4 This appears in the report of the case in $25 \mathrm{~L}$. J. (Exch.) at p. 313, but is omitted from the report of Lord Campbell's opinion in 5 H. I. C.

"Reeves: "IIistory of English Law," Vol. I, p. 87. 
of suits was cagerly encouraged by the officers of that court." 6

"In the Great Roll of 31 IIenry I, of which a description has been already given, is an entry, from which Madox understands, and Lord Campbell asserts, that Geoffrey (afterwards Bishop of Durham) purchased the office of ehancellor for the sum of $3006 l .13 s .4 d . " 7$ ". . . when it is recollected that money was then at least fifteen times more valuable than it is now, " 8 this entry becomes more significant.

"If, however, the entry in question is to be considered as a proof that a fine of that or of larger amount was imposed by the king on a grant of the office of chancellor, it would demonstrate that its dignity and importance had been greatly increased, and that its emoluments must be estimated at a very considerable standard, to be at all proportionate to the assumed price. What those emoluments were cannot now be ascertained: but from the roll referred to, some of the payments and allowanees made to the chancellor may be discovered. . . . He received fifty marks from a fine imposed on the abbot of Westminster. ....", 9

Foss tells us further that "One of the first acts of King John after the coronation was, 'at the instance' of his new chancellor Hubert, to issue an ordinance (Rymer's Fœdera, i. 75) regulating the fees of the Chancery on charters, confirmations, and protections, which had been oppressively increased 'more from inclination than reason' in the time of Richard. By this document a fee is established for the use of the chancellor of one mark of gold or ten marks of silver on a new charter, and of one mark of silver on a simple confirmation; and for the use

\footnotetext{
'See Reeves: “History of English Law,'” Vol. I, pp. 286-7, note a, buying of writs (Henry III).

"Foss: "Judges of England," Vol. I, p. 82.

${ }^{8}$ Ibid., Vol. I, p. 83.

' Ibid., Vol. I, p. 84-85.
} 
of the vice-chancellor, of one mark of silver on the former, and of one bezant on the latter." 10 Again, "The sale of the Chancery to Walter de Grey in 1205 is proved by the following entry on the Fine Roll:

" "Walterus de Gray dat Domino Regi quinque millia marcas pro habenda Cancellaria Domini Regis tota vita sua et pro habenda inde Carta Domini Regis. . .'"'10

"The fees of the Chancery, even under the new regulations just mentioned, must still have been very considerable to have warranted the demand of so large a fine." 11

"The daily salary of the chancellor, noticed in the preceding reigns, seems to have been discontinued towards the latter end of this (Henry III); when an annual salary was attached to the office. The first chancellor who was paid under this new arrangement was Walter de Merton, who, in 1261, had a grant of four hundred marks per ammuin. . . This allowance was increased in 1265, when Thomas de Cantilupe was chancellor, to five hundred marks; the words of application being still more distinct, 'ad sustentationem suam et clericorum Cancellarice nostroe'. . . .

"Out of this allowance, therefore," says Foss, "the chancellor had to pay the clerks of the Chancery; but as we do not know their number, nor the amount of their salaries, we cannot calculate what balance remained to the chancellor himself. Whatever it was, it must have been greatly increased by the fees to which he was entitled.

"We are enabled, in some measure, to estimate the amount of these fecs by the return to which I have already adverted in the time of Richard de Middleton, when John le Fauconer accounted for them to the king. The total receipt for two years was $973 l$. 16s. The disburse-

"Foss: "Judges of England," Vol. II, p. 21.

"Ibid., Vol. If, p. 22. 
ments are not fully given, but as those named amount only to the trifling sum of $19 l .6 s .31 / 2 d$., we may presume that the whole deduction would not exceed the odil sum of $73 \mathrm{l}$. 16s. Thus there would be an annual balance of $450 l$. for the ehancellor, which, with his share of the salary after paying the elerks of the Chaneery, and the other advantages arising from the office, would form an aggregate not much less in value than the income now attached to it." 12

"Both Hugh Bigot and Philip Basset had had a yearly allowance of one thousand marks for their support as chief justiciaries: but Robert de Brus ... had the grant of a salary of one hundred marks only.

". . . the allowance to the other judges never exeeding $40 l$, and sometimes being limited to $20 l$. per annum." 18

"It was not uncommon to reward the judges by grants of land. ..." 14

"Of the salary paid to the barons in this reign we have only a few examples. Soon after Alexander de Swereford's appointment, in 18 Henry III, he had forty marks per annum, and it was not increased in 27 Henry III. In 38 Henry III John de Wyville had only twenty marks, but this, perhaps, was as justice of the Jews; and Roger de la Leye and William de Clifford had 40l. a year allowed, in 49 and 55 Henry III, each being at the respective times chancellor of the Exchequer." 15

In Edward I's reign (1272-1307) "The robes of the judges were still supplied by the erown, but their salaries seem to have been reduced in this reign. The 100 marks, allowed by Henry III to Gilbert de Preston as the

\footnotetext{
12 Ibid., Vol. II, pp. 149-150.

${ }^{23}$ Ibid., Vol. II, pp. 155-156.

${ }^{14}$ Ibid., Vol. II, p. 189.

"Ibid., Vol. II, p. 199.
} 
head of the Court of Common Pleas, was continued to him during his life; but his successors, chief justices of either court, were not paid even to that extent of stinted liberality, none of them receiving more than 60 marks or 40l. a year.

"There was some little difference in the payments made to the other judges of the two courts; 50 marks being given to a few, and 40 marks to the remainder.

"That the barons of the Exchequer held a lower grade than the judges of the two other courts is evident from the amount of their salaries being limited to $20 l$. or 30 marks a year, which, to some of them, was increased, towards the end of the reign, to 40 marks.

"Making every allowance for the difference in the value of money," says Foss, "such stipends must have been wholly inadequate for the support of these officers; and if the deficiency was to be made up by fees in every variety of form, we can scarcely be surprised that the anxiety to increase them should sometimes look like extortion, and that this temptation to bribery should now and then overcome their virtue." 16

"The salary of the chief justices of both benches (King's Bench and Common Pleas), at the beginning of the reign (Edward III), was 40l. each, and that of other judges 40 marks each. The latter stipend was all that was then given to the chief baron and his associates in the Exchequer.

"By stat. 20 Edward III, chap. 1, after enacting that the judges are to take no reward from any one but the king, it is especially stated that 'for this cause we have increased the fees (les feez) of the same our justices, in such manner as it ought reasonably to suffice them."

"The word 'fee' in the statute evidently meant the salary paid to them by the king, that being the ordinary ${ }^{20}$ Foss: "The Judges of England," Vol. III, p. 44. 
name given to it; and had no reference to any larger payments to which the judges were entitled on proceedings before them." 17

"' 'That the king's servants were miserably underpaid,' says Mr. Hall, 'was admitted even then, and yet it was notorious that in most cases they were able to amass considerable fortunes. There could be little doubt where the money came from, and the crown by accepting large fines for the grant of offices which carried with them no legitimate emoluments worth speaking of, must be regarded as deliberately conniving at the robbery of the subjects.' The absence of Edward between 1286 and 1289 brought matters to a crisis. He was met upon his return with such loud complaints that he appointed a commission of enquiry. The chancellor, Robert Burnell, was at its head, and with him were associated six other commissioners. Writs were sent out to all the sheriffs in England directing all who had any complaints against royal officials to come and make them at Westminster. The result was disgraceful to all branches of the civil service, and especially to the bench. It constitutes, to use Professor Maitland's words, 'our one great judicial scandal.' of the judges of the court of King's Bench two out of three were removed; of the judges of the court of Common Pleas four out of five. The only two judges in these two courts found to be guiltless were John de Metingham and Elias de Beckingham. Five of the itinerant justices, Adam de Stratton, chamberlain of the Exchequer, Henry de Bray, an escheator, Robert de Lyttelbury, clerk or master of the rolls, and a host of minor officials were all found guilty of various crimes." 18

But whether Lord Campbell's strictures upon his predecessors in Westminster Hall were justified or not, it is

${ }^{27}$ Ibid., Vol. III, p. 357.

${ }^{18}$ W. S. Holdsworth, "A History of English Law," Vol. II, pp. $239 \cdot 240$. 
certainly not true of modern courts that they strain or over-reach themselves to secure jurisdiction of controversy. If for no other reason, the pressure of modern judicial work, the difficulty of disposing even of the business in hand, strengthens the impulse to decline jurisdiction if legitimate ground therefor can be found. In our day, there is little evidence of jealousy on the part of the courts over the disposition of controversy by private tribunals.

In a "Preliminary Report on Efficiency in the Administration of Justice," prepared by Charles W. Eliot, Moorfield Storey, Louis D. Brandeis, Adolph J. Rodenbeck and Roscoe Pound for The National Economic League, it is said:

"The great increase of litigation involved in the expansion of commerce and industry and the rapid growth of population has crowded the calendars of our courts to such an extent as to preclude the thoroughness in discussion by counsel and the deliberation in study by the court which is required in a constructive period.... The highest type of judicial law-making may not reasonably be expected under such eircumstances."

In addressing the Chamber of Commerce on June 1, 1911, Judge Vernon M. Davis, now a member of the Appellate Division of the Supreme Court of New York for the First Department, said:

"I also congratulate this Chamber of Commerce upon bringing again into existence a simple and effective plan for settling business disagreements without resort to the courts. In this, as in many other things, the Chamber has maintained its character of being alive to all public needs, and has performed an important public service. Why should business men undertake long and expensive litigation over ordinary differences arising between them? I think it must be a habit, and a bad habit, too. I am hopeful to predict, and I appeal to your experience to 
justify that prediction, that a very large number of the disputes that are now carried to the courts will be settled speedily and incxpensively under the scheme of arbitration which has just been adopted by this Chamber. ...

"The plan adopted by the Chamber is in no sense in competition with the courts, nor can it be justly regarded as a protest against any real or fancied delay in the administration of justice in this city. It has arisen out of an obvious condition of business life here, the obvious fact that it is practicable to avoid the delay and expense of a suit in court by a resort to arbitration, and the courts look upon these settlements with great favor, and it is the policy of the law to encourage arbitration, so much so that by special statute the awards of arbitrators may become the judgment of the Supreme Court, judgments of as high a sanction as those obtained in the formal litigation in the eourts."

The tendency of our day is expressed in Jackson $v$. Barry Railuray Company (1893). ${ }^{19}$ Here there was a reference to an arbitrator to determine whether or not work done under a contract was an "extra" or not, and the engineer in charge of the work was named as the arbitrator. Bowen, L. J. (the opinion has been frequently quoted) ${ }^{20}$ says: "It is no part of our duty to approach such curiously-coloured contracts with a desire to upset them or to emancipate the contractor from the burden of a stipulation which, however onerous, it was worth his while to agree to bear. To do so, would be to attempt to dictate to the commercial world the conditions under which it should earry on its business."

The most interesting and erudite question of law may be implicit in a family controversy over a will; but if the

${ }^{10} \mathrm{~L}$. R. [1893] 1 Ch. 238.

${ }^{20}$ See The Justice of the Peace (London), Vol. 75, p. 291 (June 24, 1911). 
parties are of age and do not fraudulently impose upon each other, they may, by the taking of no more formidable steps than the interchange of a few dollars and the delivery of mutual releases, dispose of the question forever and foreclose the courts from ever passing upon it. Serious questions of constitutional law, involving large matters of public policy, may never reach the courts because the good, practical sense of the parties produces a compromise upon other points. A partnership dispute presents a very neat question of law. With careful management it can be made to produce litigation sufficient to support comfortably a lawyer and his son for a year and a day. Yet the partners compose their differences, withdraw the suit already begun, or, if not begun, discharge the lawyer from all further responsibility. Does the court intervene to set aside their releases or waivers or settlements, or frown upon the transaction because it precludes the court from making some new law or perhaps, in the opinion of the court, even a fairer disposition of the issues? The Bench today will commend, not condemn, the member of the Bar who will successfully negotiate such a result and will thank him for saving the Court some labor. The Bar will approve his conduct in thus "preventing unnecessary litigation." Much nonsense is spoken about this business of "ousting the courts of jurisdiction." The truth is, the phrase has different meaning today than it had in the days of Kill $v$. Hollister ${ }^{21}$ and Thompson $v$. Charnock. ${ }^{22}$ It means today what Lord Gifford said it meant in. Wilson $v$. Glasgow Tramways $\mathrm{Co}^{23}$ "In common language where no attempt is made at logical accuracy it is sometimes said that a contract of submission or arbitration ousts the common law jurisdiction of all Judges. The parties have chosen a private Judge for themselves. But this is not

${ }^{21}$ See ante, p. 153.

${ }^{22}$ See ante, p. 166.

$\Rightarrow$ (June 22, 1878) 5 Session Cases (4th Series) 981, at p. 992. 
strictly or logically aceurate language, and, what is more important, it is not the sense in whieh the small debt statute uses the words 'incompetency' and 'defect of jurisdiction.' In strict language a contraet of arbitration does not destroy the jurisdiction of the common law Judge. It only introduces a new plea into the cause on whieh the common law Judge must deeide by virtue of his inherent jurisdiction. If he deeides that there has been a valid contract of arbitration he may take several conrses. IIe may dismiss the action, leaving the parties to go to their arbiter and eome back again, if necessary, for execution or for powers, or he may remit to the arbitrator, or suspend proceedings, or give effeet to the award. If the Common Law Judge decides that there has been no valid arbitration, or that the award is bad, or ultra vires compromissi, he will proceed aceordingly; but in dealing with arbitrations and awards the Judge is exereising his inherent jurisdiction, and is no way divested thereof, and that whether he sustains the arbitration and award or whether he refuses to do so in whole or in part. In short, the plea of arbitration is a plea on the merits of the case which, if well-founded, will, indeed, prevent the Judge from himself entering on the merits or going into proof, but which will not and cannot deprive him of his jurisdiction. If the award is good he will give effeet to it either by ordering it to be put in exeeution or otherwise. If it is bad he will disregard it, repel the plea of arbitration, and proceed with the suit in common form; but in all cases he has jurisdietion to take either eourse, and if his jurisdiction is not subject to review his decision will be final." Or as Lord Watson said in the House of Lords (May 10, 1894) : "24 "The jurisdiction of the Court is not wholly ousted by such a contraet. It deprives the Court of jurisdiction to inquire into and decide the merits of the case, whilst it leaves the Court

\footnotetext{
24 Hamlyn \& Co. v. Talistier Distillery, L. R. [1894] A. C. 202, at pp. 211-212.
} 
free to entertain the suit, and to pronounce a decree in conformity with the award of the arbiter. Should the arbitration, from any cause, prove abortive, the full jurisdiction of the Court will revive, to the effect of enabling it to hear and determine the action upon its merits. When a binding reference is pleaded in limine, the proper course to take is either to refer the question in dispute to the arbiter named or to stay procedure until it has been settled by arbitration. The latter course was adopted in Caledonian Railway Company v. Grecnock and Wemyss Bay Railway Company, where the reference was to arbiters unnamed, but had been confirmed by statute. I cite that case, not as establishing, but as illustrating the rule of procedure, which was in force long before its date." Or as Lord Campbell put it: "Where an action is indispensable, you cannot oust the Court of its jurisdiction over the subject, because justice cannot be done without the exercise of that jurisdiction. That is all, and there is no doubt about that. This is the foundation of the doctrine that the Courts are not to be ousted of their jurisdiction." ${ }^{2}$ Scott v. Avery, 5 H. L. C. 811 , at p. 853. 


\section{CHAPTER $\mathrm{XX}$}

THE ORDINARY UNDERSTANDING OF AN ARBITRATION CLAUSE

The provision in the ordinary contract of merchants that, in the event of dispute or controversy, there shall be submission to arbitration, is not intended to "oust the courts of jurisdiction" but is merely expressive of the intent of the parties to keep out of court if they can and to endeavor to compose their differences either through conciliation or arbitration.

In Scott v. Avery, Lord Chancellor Cranworth told us that the intention of the parties was "that the sum to be recovered should be only such a sum as, if not agreed upon in the first instance between the committee and the suffering member, should be decided by arbitration, and that the sum so ascertained by arbitration, and no other, should be the sum to be recovered." "And," said he, "if that was their meaning, the circumstance that they have not stated that meaning in the clearest terms, or in the most artistic form, is a matter utterly unimportant." ' And in Waters v. Taylor, Lord Eldon said: ". . the forum they have provided for themselves... [it] shows their intention against the interference of any other jurisdiction, until they have tried the effect of the special means, provided by themselves." 2

Now, whatever may be said of arbitration clauses in general, when two merchants insert in an ordinary busi-

15 H. L. C. 811 , at p. 849 . Italies ours.

$=15$ Vesey Jr. 10, at p. 17. Italies ours. 
ness contract an arbitration clause, they mean just this and nothing more:

There shall be no application to the courts "until they have tried the effect of the special means provided by themselves."

The failure so to interpret such clauses and the insistence upon some positive formula which justifies the finding of a condition precedent to a law suit, has been due, we believe, to three things, each of which we hope to establish:

(a) Failure to apply the customs and understandings of merchants.

(b) Failure to apply the doctrine of Scott $v$. Avery and II alfhide v. Fenning.

(c) Failure to realize that the dictum in Vynior's Case had long since lost its authority.

The two last of these three points we believe we have already established. The first we shall now consider.

(a) The failure to apply the customs and understandings of merchants.

The study in Part One should make it clear that Lord Eldon's remark is true-that business men do not mean to oust the courts of jurisdiction (in any logical sense of these words) but merely mean to establish in their own way the cause of action which the courts may, if need be, enforce. In Lord Coke's day it was not understood differently. Only in the later period and in but one case, Kill v. Hollister, ${ }^{3}$ did such an idea take root. Later study by the judges made this clearer. But there is much evidence still to submit to indicate beyond further question the understanding of present day business men and lawyers of the purpose of an "arbitration covenant."

In the first placn, as between business men of foreign countries and business men of our country, at least one of the parties so understands the contract. For today in every country on the face of the earth, save only our own,

$\bullet 1$ Wils. 129. 
agreements to arbitrate future differences are irrevocable and of full binding force in law. When England found her judges still wavering in applying the full force and effect of Scott $v$. Avery, she passed the statute which now makes such contracts binding.. Today, as we have seen, except for war conditions, parties in England may agree to leave their disputes to determination by the courts of Hungary or Germany, and this the courts treat as an arbitration.

Today the London Court of Arbitration may say to the New York Chamber of Commerce:

"Recourse to arbitration in this Country is very general, and it is a gratifying tribute to the efficiency with which justice is administered in the London Court of Arbitration, that Foreign Merchants readily assent to the insertion in their contracts of a clause providing for the reference of differences thereto."

So that as to mercantile contracts between merchants of other countries and merchants of our own, at least one of the parties understands the covenant to be as irrevocable and as enforceable in the courts as other covenants in the contract.

Does our own merchant understand it differently?

In Hamlyn \& Co. v. Talisker Distillery, ${ }^{5}$ the Lord Chancellor says: ${ }^{6}$ " The learned Judges in the Court below treat the lex loci solutionis of the main portion of the contract as conclusively determining that all the rights of the parties under the contract must be governed by the law of that place. I am unable to agree with them in this conclusion. Where a contract is entered into between parties residing in different places, and where different systems of law prevail, it is a question, as it appears to me, in each case, with reference to what law the parties contracted, and ae-

52 and 53 V. c. 49.

- 21 Session Cases (4th Series) 204.

- 6 The Reports 188, at pp. 193-194. 
cording to what law it was their intention that their rights, either under the whole or any part of the contract should be determined. In considering what law is to govern, no doubt the lex loci solutionis is a matter of great importance. The lex loci contractîs is also of importance. In the present case the place of the contract was different from the place of its performance. It is not necessary to enter upon the enquiry, which was a good deal discussed at the Bar, to which of these considerations the greatest weight is to be attributed, namely, the place where the contract was made, or the place where it is to be performed. In my view they are both matters which must be taken into consideration, but neither of them is, of itself, conclusive. And still less is it conclusive, as it appears to me, as to the particular law which was intended to govern particular parts of the contract between the parties. ... In this case, as in all such cases, the whole of the contract must be looked at, and the contract must be regulated by the intention of the parties as appearing from the contract. It is perfectly competent to those who, under such circumstances as I have indicated, are entering into a contract to indicate by the terms which they employ, which system of law they intend to be applied to the construction of the contract, and to the determination of the rights arising out of it.

"Now in the present case it appears to me that the language of the arbitration clause indicates very clearly that the parties intended that the rights under that clause should be determined according to the law of England. As I have said, the contract was made there; one of the parties was residing there. Where under such circumstances the parties agree that any dispute arising out of their contract shall be 'settled by arbitration by two members of the London Corn Exchange or their umpire in the usual way,' it seems to me that they have indicated as clearly as it is possible to do, their intention that that particular stipulation, which is a part of the contract between 
them, shall be interpreted according to, and governed by, the law, not of Scotland, but of England; and I am aware of nothing that stands in the way of the intention of the parties thus indicated by the contract they entered into being carried into effect."

And Lord Watson says:" "Upon the first of these questions I have been unable to arrive at the same conclusion with the Courts below. When two parties, living under different systems of law, enter into a personal contract, which of these systems must be applied to its construction depends upon their mutual intention, either as expressed in their contract, or as derivable by fair implication from its terms. In the absence of any clear expression of their intention, it is necessary and legitimate to take into account the circumstances attendant upon the making of the contract, and the course of performing its stipulations contemplated by the parties; and amongst these eonsiderations the locus contractûs and the locus solutionis have always been regarded as of importance, although English and Scoteh decisions differ in regard to the relative weight which ought to be attributed to them when the place of contracting is in one forum, ${ }^{8}$ and the place of performance in another. In the present case it does not appear to me to be necessary to discuss the relative value of these considerations, because, in my opinion, the clause of reference is expressed in terms which clearly indicate that the parties had in contemplation and agreed that it should be interpreted according to the rules of English law. If they had stipulated that all disputes arising out of the contract were to be decided in the Court of Session I should have been of opinion that they had in view the principles of Scotch law, and meant that their mutual stipulations should be construed according to these principles. And, to my mind, their selection from the membership of a commercial body

? 6 The Reports 188, at p. 198.

- Italics ours. 
in Iondon of a conventional tribunal which is to act 'in the usual way,' or, in other words, in the manner which is customary in London, indicates, not less conclusively, that, in agreeing to such an arbitration, they were contracting with reference to the law of England."

Lord Ashbourne says: ${ }^{10}$ "A contract which provided that disputes should 'be settled by arbitration by two members of the London Corn Exchange or their umpire in the usual way,' distinctly introduces a reference to well-known laws regulating such arbitrations, and those must be the laws of England. This interpretation gives due and full effect to every portion of the contract, whereas the arbitration clause becomes mere waste paper if it is held that the parties were contracting on the basis of the application of the law of Scotland which would at once refuse to acknowledge the full efficacy of a clause so framed."

Again, the Lord Chancellor (Herschell) in this case says: " "But then it is argued that an agreement to refer disputes to arbitration, deals with the remedy and not with the rights of the parties, and that consequently the forum being Scotch, the parties cannot by reason of the agreement into which they have entered interfere with the ordinary course of proceedings in the Courts of Scotland. . . . Stated generally I should not dispute that proposition so far as it lays down that the parties cannot, in a case where the merits fall to be determined in the Scotch Courts, insist, by virtue of an agreement, that those Courts shall depart from their ordinary course of procedure. But . . . that is not really the question which has to be determined in the present case. The question which has to be determined is whether it is a case in which the Courts of Scotland ought to entertain the merits and adjudicate upon them. If it were such a case, then no doubt the ordinary course of pro-

- 6 The Reports 188, at p. 198.

${ }^{10}$ Itid., p. 201.

"Ibid., p. 196. 
cedure in the Seotch Courts would have to be followed; but the preliminary question has to be determined whether by virtue of a valid clause of arbitration, the proper course is for the Courts in Scotland not to adjudicate upon the merits of the ease, but to leave the matter to be determined by the tribunal to which the parties have agreed to refer it. . . . Viewed in that light $\mathrm{I}$ can see no difficulty, and the argument that to give effect to this arbitration clause would interfere with the course of proeedure in the forum in which the action is pending, seems to me entirely to fail." 12

Lord Kinnear said in the same ease: ${ }^{13}$ "The contract which they made in these cireumstances is that disputes should 'be settled by arbitration by two members of the London Corn Exchange, or their umpire, in the usual way.' Now, when a London merchant stipulates that disputes under his contract are to be referred to members of such a body as the London Corn Exehange-that is, to merchants or brokers earrying on business in the city of London-I think that that means that the tribunal is to be constituted and the arbitration conducted in London; and when it is farther stipulated that the arbitration is to be by two members of the Corn Exehange, 'or their umpire, in the usual way,' I think that that imports a reference to a known law and practice regulating the constitution and conduct of such arbitrations, and that can only be the law and practice of England."

English judges and English merehants find it hard to understand why, in an agreement which reads "In case of difference, arbitration in the usual way by the London Board of Trade," our courts shouid be astute to find that the intent of the parties was to contraet in accordance with our law, and that according to our law, the contract is invalid. Such decisions eneourage unethieal conduct upon

${ }^{12}$ Italies ours.

1s 21 Session Cases (4th Series) 204, at p. 212. Italies ours. 
the part of business men. For it is the elear intention of the modern merchant that, whichever law is to apply, there is to be no litigation until after an award is made. Otherwise he stultifies himself. The most reeent authority in England ${ }^{14}$ holds that when merehants insert a clause that a dispute is to be arbitrated "in the usual way," they do not mean thereby "according to the law (of arbitration) of the land," but they do mean "aceording to the habitual custom of their trade."

A very modern interpretation is the Massachusetts leading case of Mittenthal $v$. Mascagni, decided in 1903. ${ }^{15}$ Maseagni, the great composer, while a subject of Italy, made in Florence a contract with a manager to direet certain eoncerts and present certain operas, eomposed by him, in a fifteen weeks' tour through the United States and Canada. This eontract eontained a provision, in substance, that the contract should be governed entirely by the laws of Italy and that any suit upon it should be brought in the Courts of Florence, except that Mascagni might, if he ehose, sue in the Courts of New York for his compensation. Fancy -all other courts save those of Florence and New York completely "ousted" of jurisdiction! What would a Massachusetts court say to that?

Knowlton, C. J., says, ${ }^{16}$ with what would seem to be a very fine applieation of common sense: "We can fancy the parties to this contract at the time of making it saying something like this: "As the performance of this eontract will not only involve travel through one or more foreign countries in going to America and returning, but will involve journeying long distanees through a great many independent States, each of which has its own eourts and system of laws, under some of which a person sued in a civil action, when about to leave the State may be arrested and

\footnotetext{
${ }^{14}$ Bright $v$ Gibson, 1916. Vide ante, pp. 223-224.

15 183 Mass. 19.

${ }^{18}$ lbid., JP. 23-24.
} 
held to bail or in imprisonment, if suits may be brought in any one of these numerous jurisdictions, there is a liability to great trouble and expense on the part of the defendant in meeting the litigation. The contract contemplates a service of fifteen weeks, after which Maestro Mascagni intends to return to his permanent home in Florence. It will be better and more reasonable for both of us to provide that our controversies, if any arise, shall be settled by the courts of Florence, than to leave both parties subject to suits in forty or fifty different jurisdictions, at great distances from the home of either.'" Then he asks: "If, moved by such considerations, the parties made the agrcement in question, shall the court say that they were non compotes mentis, and that their agrcement was so improvident and unreasonable that it cannot be permitted to stand?" This Court finds that "the tendeney in modern times is to permit greater freedom in contracting in matters of this kind than formerly" and eites several modern Massachusetts decisions. ${ }^{17}$

It is convinced that the "determining question" is "whether such a contraet as this is so improvident and unreasonable, sueh an abnegation of legal rights, that the government, for the protection of mankind, will refuse to recognize it, even when made in a foreign country by subjects or citizens of that country." 18 And it recognizes clearly that such a provision as this "is analogous to the limitation of the subjects of which the courts shall have exclusive jurisdiction, by a provision for the arbitration of incidental and subsidiary questions out of court, which is approved in cases above cited. It is also analogous to the limitation by contract of the time within which suits may be brought." 10

"Miles v. Schmidt, 168 Mass. 339; Daley v. People's Building Loan \& Saving Association, 178 Mass. 13.

${ }^{18} 183$ Mass. 19 , at p. 23.

${ }^{10}$ Eliot National Bani v. Beal, 141 Mass. 566. 
Accordingly, in Massachusetts such a clause is held to be valid. It is true that the Court calls attention to the fact that the contract is one "between eitizens of foreign States who, so far as our tribunals are concerned, well might make any reasonablc arrangement for the settlement of their disputes." But the Court does not rest its decision upon the mere fact of foreign citizenship, for it says: "In most cases, certainly in a case like the present, there is no occasion for the protection of the dignity or convenience of the courts." ${ }_{20}$ Shall we give to foreigners the right to "make any reasonable arrangement for the settlement of their disputes" and deny it to our own eitizens? "There is no attempt here ${ }^{21}$ to deprive either party of the right of appeal to the courts ... but only an attempt to narrow the area within which suits may be brought."

But that is precisely what is intended by the usual arbitration clause, is it not? It does not deprive either party of the right to sue; it merely fixes the method for determining the liability. No one is deprived of his protection by the court, especially under submissions which have the sanction of legislative authority. Even a Common Law arbitration can be enforced by the courts. It was the denial of the right to apply to the courts for specific enforcement of such an agreement which ousted the courts of equity of their inherent power, not the agreement itself. If Baron Jeffreys' decision in Norton $v$. Mascall ${ }^{22}$ or Lord Eldon's in Waters v. Taylor ${ }^{23}$ were applied today, such agreements would give to the parties the same rights to enforce them in the courts as are conferred upon them by all other reasonable contracts.

Lord Romer held in the same year (1903) in England in Austrian Lloyd Steamship Company v. Gresham Life As.

${ }^{20} 183$ Mass. 19 , at p. 23 . Italies ours.

"I lid., p. 24.

22 "Reports of Cases in Chancery," Vol. II, p. 304 (1694).

${ }^{23} 15$ Vesey $\mathrm{J}_{1}, 10$. 


\section{THE ORDINARY UNDERS'TANDING 275}

surance Society ${ }^{24}$ that the agreement of the partics to submit any dispute arising under the contract to the Courts at Budapest amounted to nothing more than the nominating of "a particular individual as arbitrator" and an "agreement to submit any dispute under the contract to the arbitration of that person." And, accordingly, it was declared to be valid. ${ }^{25}$

Over a century before Lord Ellenborough was called upon, in the Courts of England, to consider the same point. He made no distinction between subjects of England and foreign subjects. The clause he had under consideration was one whereby seamen, before taking their trip for a Continental port, agreed: "That they would not in foreign parts prosecute payment of any money whatever of the captain, but be satisfied with what he might be pleased to advance them abroad in deduction of their wages." The report says that "Topping for the plaintiff, contended that this was no bar to the present action. The parties by their private agreement could not oust the jurisdiction of our courts. The plaintiff might be liable in his own country for suing here; but the only thing to be considered in this cause was, whether the wages were due." Lord Ellenborough said that if this had been "the regulation of a foreign government," he would "leave that government to enforce it" by penal or other effective remedy. "But," says he, "by the personal contract between the individuals before the court, it is expressly stipulated that the mariners shall not sue the captain for wages in foreign parts. It is impossible for me to say that this stipulation is void."

${ }^{24}$ L. R. [1903] 1 K. B. 249.

${ }^{25}$ The clause here read: "Pour loutes contestations qui pourraient surgir du contrat d'assurance toutes les parties intéressées se soumettent de convention expresse à la jurisdiction des tribunaux compétents de Budapest,", which translated by the Anglo-French jurist, Mr. Thomas Barclay, read as follows: "For all disputes which may arise out of the contract of insurance, all the parties interested expressly agree to submit to the jurisdiction of the Courts of Budapest having jurisdiction in such matters." 
"There may be great reason," said this learned English judge further, "for proteeting the eaptain from suits in foreign countries, where he may have no funds to answer the demands of the mariners; and it may be conducive to the interests of eommerce that the mariners should have the strongest indueement to remain in the ship till the adventure is eompleted. The rate of wages might be in part determined by the condition that they were not demandable till the ship's return home."

"The agreement," it is true, as he says, "was made abroad; but it is transitory; and we are bound as far as we are able to give it the same construction and effect which it would receive in the country where it was made." 26

In another Massaehusetts ease, ${ }^{27}$ Judge Holmes (now of the United States Supreme Court) held that an agreement by stoekholders that "Any aetion brought against this Association by any Shareholder shall be brought . . . in the County of Ontario, State of New York" was valid and a bar to suit in Massachusetts.

Judge Holmes was not terrified by any fear of "ouster" of the Massachusetts court's jurisdietion. Said he: "It is true that in this ease the question is not between counties but between States, and that our decision requires a resident of Massachusetts to go elsewhere for a remedy upon a contract made here. Reichard v. Manhattan Ins. Co., 31 Mo. 518, 520, 521. But objeetions of this sort may be made to appear more serious than they are. Courts are less and less disposed to interfere with parties making sueh contraets as they choose, so long as they interfere with no one's welfare but their own. The plaintiff might have given his money to the corporation if he had seen fit. We see no

\footnotetext{
- Johnson v. Marhielsen, 3 Camph. 44 (1811). Italies ours.

${ }^{27}$ Daley $v$. Pcople's Building, \&c. Assoc., 178 Mass. 13.
} 
reason why he might not give it upon such partial return as he was content to aceept." 28

But the Massachusetts courts have not been consistent. They still hold that an arbitration elause is "ousting the courts of jurisdiction," ${ }^{29}$ saying "It is well settled in this Commonwealth, that an agreement to refer to arbitration will not be enforced in equity, and will not be sustained as a bar to an action at law or a suit in equity." Thus, having deprived the parties of all recourse to the courts either of law or equity to enforce an agreement into which presumably they entered while taking full account of the business factor of expeditionsly disposing of possible controversy, the Court holds that by so agreeing they have completely ousted the eourts of jurisdiction..$^{30}$

The New York courts are more consistent. In Meacham v. Jamestown, F. \& C. R. R. Co. (1914), 31 Judge Cardozo finds that the Court had already held that "an agreement that a foreign court shall have exclusive jurisdiction is to be condemned" (eiting Benson v. Eastern B.\& L. Assn., 174 N. Y. 83), so cannot decide that it is "saved by a declaration that resort to the foreign court shall be deemed a condition preeedent to the accrual of a cause of action. A rule would not long survive if it were subject to be avoided by so facile a device," says he. He can find no difference in application "whether the tribunal is a court or a board of arbitrators," except that in the case of judicial tribunals of other eountries "we yield to regular

${ }^{28}$ Ibid., pp. 19-20.

29 See Brocklehurst \& Potter Co. v. Marsch, 225 Mass. 3 ; Roed v. Washington Fire \& Marine Ins. Co., 138 Mass. 572.

${ }^{30} \mathrm{In}$ this connection, it is well to bear in mind that the Massachusetts courts are still following Hortor $v$. Sayer, 4 H. \& N. 643, Roper $v$. Lendon, 1 El. \& El. 825, Dawson v. Fitzgerald, L. R. 1 Ex D. 257, Edwards v. Aberayron Ins. Soc., L. R. 1 Q. B. D. 563, the obsolete character of which as guiding English precedents we havo already disclosed (see ante, pp. 185-186, 192-195). See Recd v. Washington Fire \& Marine Ins. Co. (1S85), 138 Mass. 572, at p. 577, Nute v. Hamilton Ins. Co., 6 Gray 174, and Hall v. People's Ins. Co., 6 Gray 185.

s1 211 N. Y. 346, at p. 352. 
and duly organized agencies of the state and in the other to informal and in a sense irregular tribunals." Thus the New York courts refuse to follow Lord Ellenborough, Lord Romer, and Judge Knowlton of Massachusetts, and treat contracts referring future controversy to other tribunals than their own (whether "regular and duly organized agencies of the state" or "informal and in a sense irregular tribunals") as void and unenforeeable. In this respeet they follow the fundamental error to its logical end, for Judge Cardozo makes it elear that to reason "that resort to the foreign court shall be deemed a condition preeedent to the acerual of a cause of action" is but to avoid the rule by "a faeile deviee." Nevertheless, as we have seen, the courts of New York (as did the courts of England) make this very distinction in sustaining some arbitration elauses and invalidating others. The truth is, that until the nettle is grasped by the thorns there is no logieal consistency in the deeisions. ${ }^{32}$ Judge Cardozo, universally counted one of the ablest judges in New York, permits himself in the Meacham ease to say:

"The jurisdietion of our courts is established by law, and it is not to be diminished, any more than it is to be increased, by the convention of the parties."

Yet every day, one might say every hour, parties by their own agreements withdraw from the courts matters whieh they think can better be disposed of by settlement, by general release, by arbitrament, and the courts not only assent to the arrangement but commend it. Most assuredly, if Judge Cardozo had discovered that fundamental preeedential error had erept into the law of New York, he would have been the first to eorrect and set right the eommon law of his State, as he has done in other cases in which judieial error was committed. ${ }^{33}$

${ }^{32}$ See Engel v. Shubert Theatrical Co., 166 App. Div, 394 and brief therein of Walter H. Pollak. 395.

${ }^{23}$ See opinion in People v. Charles Schweinler Press, 214 N. Y. 


\section{CHAPTER XXI}

\section{CONCLUSION}

Ir Is no reflection upon the administration of justice that the desire of merchants to kacp out of courts should persist in spite of the very many improvements that have been made in judicial machinery. We may not wholly subscribe today to what Matthew Bacon said: "It is one of the greatest Objections to our Laws, that the Way to the Knowledge of them is so dark and rugged, so full of Windings and Turnings, that the most Knowing very often find it difficult to be able to pronounce with Certainty, concerning some Points they are sollicitous about.", 1

Yet, as Kyd points out, even after a complete system of law and regular courts for the distribution of justice are erected, by reason of the necessity of giving certainty to their decisions courts are, in fact, obliged "to adapt peculiar forms of action, and modes of pleading, to the particular nature of the case, and to establish certain formalities in the manner of bringing the parties before the court." Consequently, "The consideration of expence, that must necessarily be incurred before a hearing can be obtained, and a fear that a technical mistake in some part of the proceedings may endanger the parties success, often prevail with him (the merchant), though satisfied of the justice of his cause, to refer it to the decision of an indifferent person, before whom we may explain every circumstance,

s "The Compleat Arbitrator or the Law of Awards," Matthew Bacon, p. iii. 
without the apprehension of failing from ignorance of form."'2

And it is a healthy thing for Soeiety to dispose of controversy without friction. It was the praetice of Confucius to summon the disputants before him and to talk to them of the futility of quarrels. "IIe importuned them to settle anicably any controversies that alose. It was his objeet to have the combatants meet in complete understanding. Then it was that he set forth his famous maxim: 'You should not do to others that which you would not have others do to you.'

"His principle of government was 'Love thy neighbor as thyself.' It was his object to put down strife and have the people decide their own disputes." 3

In the Bible we read: "Agree with thine adversary quickly, whiles thou art in the way with him; lest at any time the adversary deliver thee to the judge, and the judge deliver thee to the offieer, and thou be cast into prison." *

Nowhere has this spirit of pacific adjustment taken on finer form than in the recent eoöperative action of the Bar of New York State and the Chamber of Commerce of the State. Recognizing that this aim of business men was one to be faeilitated, not handicapped, the Bar of New York State has now joined hands with the business men of the State in providing ready machinery for commereial arbitration. Today there is available for every kind of controversy an "Official List of Arbitrators" made up of lawyers, or of business men, awaiting one's choice. The "Rules for the Prevention of Unneeessary Litigation"' (see Appendix A) were designed to aid merchants with wise counsel and advice before controversy arises, and, when it

"A Treatise on the Law of Awards"-Stewart Kyd, pp. 2, 3. Italics ours.

"Scott: "The Evolution of Law," pp. 99-100.

- Matt. V., 25. 
does arise, to put at their command simple machinery with which to dispose of it quickly.

Why should such a movement be hampered by the continuance of a rule unsound in public policy, bad in legal theory, obsolete historically and unsupported by sound legal precedent? Only lack of true information has kept it alive so long. But "Ignorantia Legis Neminem Excusat." (Ignorance of the Law excuses no man) This ineludes the Lawyer and the Judge, does it not? And if repudiation of one's promise to arbitrate is, as Lord Eldon put it, immoral, why continue to lend legal sanction to it? 



\title{
APPENDICES
}

\author{
APPENDIX A
}

REPORT OF THE JOINT COMMITTEE OF THE CHAMBER OF COMMERCE OF THE STATE OF NEW YORK AND OF

THE NEW YORK STATE BAR ASSOCIATION.

Approved by the Chamber of Commerce, November 2, 1916.

Rules for the Prevention of Unnecessary Litigation

Object of the Rules-It would be impracticable for the Chamber of Commerce of the State of New York and the New York State Bar Association to attempt to lay down rules of law for the guidance of laymen. That would be an attempt to write law books and to make every man his own lawyer. Such a course would be futile. It would promote, rather than prevent, unnecessary litigation.

The attempt here made is simply to put in concrete form a few common sense rules of business which experience has proved to be valuable in the prevention of unnecessary litigation. As litigation and its prevention are peculiarly within the province of the legal profession, these rules necessarily relate, in large measure, to the advice of counsel and to the poini at which it is to the interest of the business man to turn to his lawyer for guidance.

These rules are constructed on the theory that prevention is preferable to eure. They contain nothing that is new and much that is necessarily general and commonplace. If they did not represent a common experience, they would be useless. Therefore, in the preparation of these rules, an effort has been made to present recognized business principles in the simplest form and even to formulate what may sometimes seem to be self-evident truths. Even if the truths are trite, the fact that they are formulated may serve as a reminder at a critical moment. 
Unnecessary Litigation Defined-Litigation may be said to be unnecessary if it can be prevented by the exercise of reasonable care. There are three points at which reasonable care is specially effective. Care at the source is, of course, most effective. After the facts become fixed and before suit, it may or may not prevent litigation. After suit, it may reduce the litigation. These rules are accordingly divided into three parts:

I. Prevention of Litigation at the Source.

II. Prevention of Litigation after the Facts become fixed and before Suit.

III. Prevention of Litigation after Suit.

\section{PART II}

\section{Prevention of Litigation after the Facts Becone Fixed and Before Suit}

After the facts upon which a dispute can be based bave become fixed, either before or after a dispute has arisen, it is possible to do much to prevent litigation. What can best be done in each case and whether with or without legal advice, necessarily depends upon the facts and the parties to the prospective controversy. Differences may be minimized, adjusted or arbitrated. If not so disposed of, litigation will usually ensue.

RTLE 1. In the matter of good faith give your adversary the benefit of the doubt.

RCLE 2. Remember that pugnacity, vindictiveness, ill temper, impatience, carelessness, short-sightedness, arrogance, eagerness to take undue advantage and insistence on unethical principles are all provocative of litigation. Even if these instincts are inherent in human nature they may be controlled by an impartial consideration of the facts and a proper exercise of the reasoning powers. Before rusining into litigation wise legal advice of the right sort is all important.

RuLE 3. Endearor to look at both sides of a situation in a calm and impartial manner. Eliminate all personal animosity.

RULE 4. Discuss your differences fairly, frankly, patiently, without prejudice and with due regard to the sensibilities of the 
other parties in interest, or employ a lawyer who will do so.

RULE 5. In such discussions with adverse parties aroid making positive assertions, even if true, which may be offensive, but rather state the same facts in a diplomatic manner not calonlated unnecessarily to arouse antagonism.

RULE 6. Throw all light possible upon the questions involved in the controversy in order that nothing shall be concealed which, if known, might harmonize dirergent views.

RULE 7. Display a spirit of conciliation and be prepared to make some concessions, if necessary, to avoid a breach.

ROLE 8. Remember that "a lean settlement is better than a fat law suit."

RULE 9. When negotiations fail to settle a dispate submit the questions to arbitration and abide by the decision of the arbitrators.

Minimizing Differences-It sometimes happens that, notwithstanding the die is cast that foreshadows a dispute, it is possible to pursue some course of action which will hare the effect of redacing differences or damages to a minimum. Such a course must generally be promptly undertaken and may or may not require legal advice, depending upon the parties and the questions involved.

Adjustment of Differences-Differences may be adjusted by the farties themselves or with the aid of a mutual friend or their legal advisers. Which method is better depends upon the parties and the questions concerned. When questions of law are involved, the legal opinion of a lawyer acceptable to both parties is often sufficient.

Submission of Controversy upon Agreed Statement of FactsPersons of full age may submit to the conrt upon an agreed statement of facts any question of difference which might be the subject of an action. This should never be done without adrice of counsel.

The usual difficulty with this procedure is that the parties wilk not agree upon the facts thus rendering a legal or equitable action necessary.

Where the parties are able to agree, however, this method of procedure is speedy, amicable and effective, resulting in a formal judgment of the court. 
Arbitration-Where differences cannot be adjusted between the parties or their attorneys and the intervention of a third party beeomes necessary, there are several forms which arbitration may take. The arbitration may be (1) informal, (2) under the Code, (3) under the auspices of a commercial body, or (4) under the anspices of a bar association.

The experience of many business men and lawyers testifies to the advantage of these methods of adjusting differences wherever possible. They are inexpensive, speedy and peaceful.

Parties who may arbitrate-Under the law of this state a corporation or any person of full age and sound mind may enter into arbitration.

Disputes which may be arbitrated-Under the law of this state any existing controversy may be submitted to arbitration except a claim to an estate in real property in fee or for life.

Where the sole arbitrator is a lawyer, or where the submission provides that a lawyer on the board of arbitrators shall be sole judge of the law, there is no reason why substantially any question of law or fact involving property rights should not be arbitrated, provided the parties interested are of full age and sound mind. In arbitrations involving technical questions, whether in law or special lines of business, experience has shown the advantage of selecting as arbitrators persons in that particular line of business or otherwise familiar with the trade customs or technicalities involved.

The following are peculiarly appropriate subjects for Arbitration : disputes concerning contracts, wills, mechanics' liens, insurance policies, sale and delivery of goods, partnerships, commissions, value of services, and particularly disputes arising out of business transactions in foreign countries, etc.

Informal Arlitration-Informal arbitration is simply the submission of a controversy to a third party without formality with an understanding to abide by the decision. Such third party may be a business man or a lawyer whose legal opinion is acceptable to both. This method is often very effective when the controversy is one that can be settled out of court.

Arbitration under the Code-The Code provides a complete system for the arbitration of differences before one or more arbitrators to be selected by the parties. A written submission to 
arbitration is required and, at the option of the parties, it may provide for a judgment of the court to be entered on the award.

Arbitration under the Auspices of Commercial Bodies-The New York Chamber of Commerce and many other commercial bodies have provided systems of arbitration not only for the use of their own members but also for non-members whether eitizens of this or any foreign country. They maintain committees of arbitration to supervise such matters.

Arbitration under the Auspices of the New York State Bar Association-Following the example of commercial bodies, the New York State Bar Association has established under its auspices a system of arbitration which it deems practicable for lawyers to recommend to clients wishing to settle their disputes by arbitration. With one or more lawyers sitting in each case, arbitrators are enabled to pass upon questions of law as well as questions of fact.

\section{PART III}

\section{Prevention of Litigation after Suit}

After a suit has been commenced, the parties should leave its management and all negotiations relating to the conduct or settlement thereof in the hands of their respective counsel.

The Chamber of Commerce of the State of New York and the New York State Bar Association, with a view to the prevention of unnecessary litigation after suit, urge upon members of the Bar that they make effort, even after litigation has begun, to bring about an amicable adjustment of differences; or, where this is impossible, to reduce disputed facts and disputed questions of law to a minimum. The Chamber and the Bar Association recommend that, in arranging for conferences, members of the Bar call attention to this recommendation as the opinion of public bodies submitted for the guidance of parties involved in litigation.

It would seem to be within the power of counsel in most cases to bring the parties together, if not upon terms of settlement, at least upon facts which should not unnecessarily occupy the time of the Court. To that end parties and counsel are urged to encourage agreements and stipulations concerning the facts wherever possible. 
In this connection a perusal of the rules under Part II is commended to all parties in interest.

\section{APPENDIX B}

RULES AND REGULATIONS OF THE CHAMBER OF COMMERCE OF THE STATE OF NEW YORE

I

All Submissions shall be in proper form and a copy filed with the Clerk, duly acknowledged before a notary or other authorized official as required by law, together with sufficient evidence of proof of authority in the case of an agency, partnership or corporation,

(a.) If signed by an agent, duly authenticated copy of his power of attorney;

(b.) If signed by one or more partners, written consent from co-partners not signing Submission;

(c.) If signed in behalf of a corporation, duly certifled copy of resolution authorizing Submission.

II

The proceedings shall not be public unless requested by the parties. Members of the Committee on Arbitration may be present at any of the hearings. The records shall be open at all times to members of the Chamber of Commerce and others upon the written order of the Committee on Arbitration.

\section{III}

'The hearing of cases shall commence as soon as practicable after Submission, and shall be pressed to speedy termination.

\section{IV}

All irrelevant or animportant matters shall be excluded.

V

The Arbitrators shall construe these rules and the submission to them as being designed to secure reason and equity in matters of 
trade and commerce, with the least possible expenditure of time, energy and moncy and in such manner as to avoid all unnecessary irritation.

\section{VI}

If three Arbitrators are chosen, the one chosen from the "List of Official Arbitrators" shall act as Chairman.

\section{VII}

Each party to the Arbitration shall be entitled to a copy of the award.

\section{VIII}

The Chamber of Commeree will provide the parties who submit to Arbitration under its rules, with adequate room and all necessary forms and papers free of charge, and through its Committee on Arbitration, will endeavor to do or cause to be done all such acts as it properly may do for the purpose of assisting the parties and the Arbitrators in the course of an Arbitration.

\section{IX}

Each party shall furnish his own witnesses, paying the fees thereof.

\section{$\mathrm{X}$}

A competent stenographer shall be employed, and the expense for this service is to be charged against the parties to the Submission as the Arbitrators may decide.

\section{XI}

In case of any misunderstanding or any question eoncerning the interpretation of these Rules and Regulations, the decision of the Committee on Arbitration of the Chamber of Commerce shall be accepted by the parties as conclusive.

\section{XII}

Wherever the word "Party" or "Parties" is used in these rules it shall refer to the parties to the Submission, and wherever the word "Arbitrator" or "Arbitrators" is nsed it shall refer to the 
Arbitrator or Arbitrators as the case may be, whether there are one or more. Whenever the word "Committee" is used, it shall refer to the Committee on Arbitration of the Chamber of Commerce. Whenever the word "Clerk" is used, it refers to the Clerk of the Committee on Arbitration.

\section{FEES}

All fees of Arbitrators, expense for stenographers and other minor expenses shall be awarded as the Arbitrators may decide.

\section{DEPOSIT}

The parties to the Submission shall each deposit with the Clerk at the time of filing the Submission, the sum of $\$ 60.00$ - or at the discretion of the Committee, a larger amount-which shall be disbursed by him for their account in payment of Arbitrators' and stenographers' fees and minor expenses:

(a.) Arbitrators' fees : $\$ 10.00$ per day or part thereof;

(b.) Stenographers' fees: the usual remuneration;

(Note.-The fees for Stenographer are based on the following:

25 cents per folio of 10 lines, and 5 cents per folio each for the second and third copies.)

If the Deposit appears insufficient to the Clerk, or becomes exhausted, he shall call upon the parties equally for such further sums as may be required: any balance to be refunded as the Arbitrators may decide.

\section{THE CLERK}

The duties of the Clerk of the Committee on Arbitration shall be as follows:

He shall receive and file all Submissions, all copies of awards, give notice of all hearings, keep a docket of all eases, and such other books and memoranda as the Committee shall from time to time direct.

He shall render all necessary assistance to the Arbitrators, attend to their clerical work; receive and disburse all fees and costs 
and keep careful and aceurate account thereof, under the supervision of the Committee on Arbitration.

If the clerk of the Committee on Arbitration is unable to attend, the Assistant Secretary of the Chamber of Commerce shall take bis place.

\section{AMENDMENTS}

The Committee reserves full power to amend, add to or omit any of these rules from time to time, as may be found expedient.

\section{FORMS OF SUBMISSION}

To Be Used in Submitimg for Arbitration Cases of DIFFERENCE

\section{Form A}

The Committee on Arbitration of the Chamber of Commerce of the State of New York

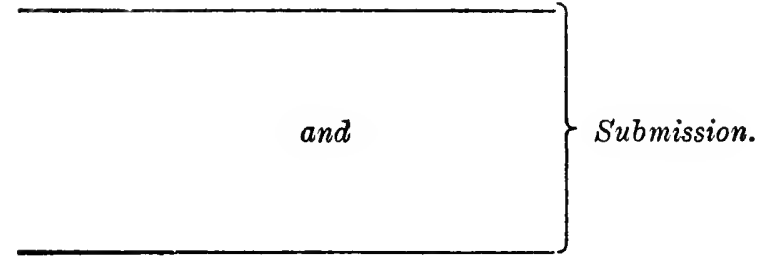

A controversy, dispute or matter of difference between the undersigned having arisen and relating to a subject matter the nature of which, briefly stated, is as follows:

We do hereby voluntarily submit the same and all matters concerning the same to as Arbitrator, selected by us from the "List of Official Arbitrators," compiled and established by the Committee on Arbitration of the Chamber of Commerce of the State of New York, for hearing and decision pursuant to the By-laws of the Chamber of Commerce of the State of New York, and the Rules and Regulations adopted by 
the Committee on Arbitration of the Chamber of Commerce, and pursuant to Chapter 17, Title VIII. of the Code of Civil Procedure of the State of New York, and we agree to stand to, abide by and perform the decision, award, order, orders and judgment that may therein and thereupon be made under, pursuant and by virtue of, this submission.

And we do further agree that a judgment of the Supreme Court of the State of New York, may be entered in any County in the State of New York thereon.

We do also in all respects waive any right to withdraw from or revoke this submission after the arbitrator or arbitrators accept their appointment hereunder, hereby expressly and specifically waiving the provisions of Section 2383 of the Code of Civil Procedure.

Dated, New York.

(Usual forms of eorporate and individual acknowledgments before notaries, etc.)

\section{Form B}

Tre Committee on Arbitration of the Chamber of Commerch of the State of New York

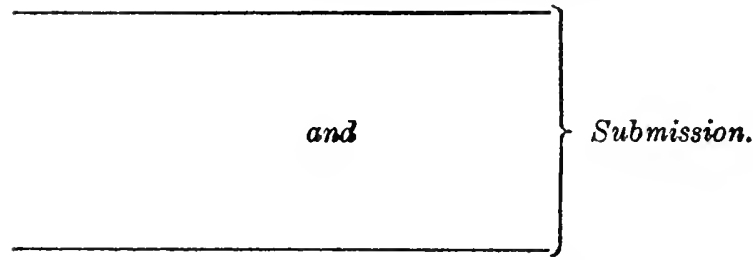

A controversy, dispute or matter of difference between the undersigned having arisen and relating to a subject matter the nature of which, brielly stated, is as follows:

We do hereby voluntarily submit the same and all matters coneerning the same to and

who shall seleet a third arbitrator from the "List of OFFicial Arritrators," compiled and established by the Committee on Arbitration of the Chamber of Commerce of the State of New York, for hearing and decision pursuant to the By-laws of the Chamber of Commerce of the State of New York, and the Rules 


\section{APPENDICES}

and Regulations adopted by the Committee on Arbitration of the Chamber of Commerce, and pursuant to Chapter 17, Title VIII. of the Code of Civil Procedure of the State of New York, and we agree to stand to, abide by and perform the decision, award, order, orders and judgment that may therein and thereupon be made under, pursuant and by virtue of, this submission.

And we do further agree that a judgment of the Supreme Court of the State of New York may be entered in any County in the State of New York thereon.

We do also in all respects waive any right to withdraw from or revoke this submission after the arbitrator or arbitrators accept their appointment hereunder, hereby expressly and specifically waiving the provisions of Section 2383 of the Code of Civil Procedure.

Dated, New York.

Forar $\mathrm{C}$

The Committee on Arbitration of the Chamber of Commerce of the State of New York

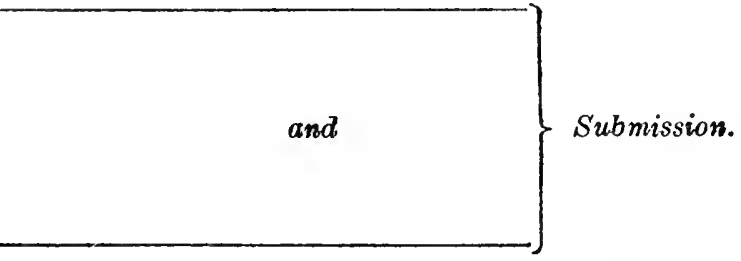

A controversy, dispute or matter of difference between the undersigned having arisen and relating to a subject matter the nature of which, briefly stated, is as follows:

We do hereby voluntarily submit the same and all matters concerning the same to

as Committee on Arbitration of the Chamber of Commerce, or a quorum thereof, as Arbitrators selected by us for bearing and decision pursuant to the By-laws of the Chamber of Commerce of the State of New York, and the Rules and Regulations adopted 
by the Committee on Arbitration of the Chamber of Commerce, and pursuant to Chapter 17, Title VIII. of the Code of Civil Procedure of the State of New York, and we agree to stand to, abide by and perform the deeision, award, order, orders and judgment that may therein and thereupon be made under, pursuant and by virtue of, this submission.

And we do further agree that a judgment of the Supreme Court of the State of New York may be entered in any County in the State of New York thereon.

We do also in all respects waive any right to withdraw from or revoke this submission after the arbitrator or arbitrators aceept their appointment hereunder, hereby expiessly and specifically waiving the provisions of Section 2383 of the Code of Civil Procedure.

Dated, New York.

\section{APPENDIX C}

\section{ILLINOIS LAW OF ARBITRATION}

\section{Approved June 11, 1917.}

Section 1. Be it enacted by the People of the State of Illinois, represented in the General Assembly: That all persons having requisite legal eapacity may by an instrment in writing to be signed by them submit to one or more arbitrators to be named in the manner indicated by such writing, any controversy existing between them, and may, in such submission agree that a judgment of any court competent to have jurisdietion of the subject matter of such instrument, shall be rendered upon the award made pursuant to such submission.

SEc. 2. The parties to such submission may by such submission designate the number of such arbitrators, which number may be one or more as the parties shall agree; the manner in which they may be appointed in the first instance and racancies caused by the refusal, incapacity or death of an appointee filled; the time and place of the hearing and the rules for the hearing 
of such controversy, not in conflict with the provisions of this Act; the parties to such submission may include by reference in said written submission the published rules of any organization or association which rules shall thereby become a part of the contract of submission.

SEC. 3. A submission to arbitration shall, unless a contrary intention is expressed therein, be irrerocable.

SEc. 4. Said arbitrators or any of them shall have the power to administer oaths, subpoena and examine witnesses, to issue subpoenas duces tecum requiring the production of such books, papers, records and documents as may be evidence of any matter under inquiry and to examine and inspeet the same; service of such subpoena shall be made by any sheriff or constable or other person; the fees of witnesses for attendance and travel shall be the same as the fees of witnesses before the cireuit courts of this State; any court of this State, lhaving jurisdietion of the subject matter of the submission or any judge thereof upon the application of such arbitrators or any of them, either in term time or vacation may compel attendance of witnesses, the production of books and papers and giving of testimony before said arbitrators by attachment for contempt or otherwise in the same manner as the production of evidence may be compelled before said court.

SEC. 5. The said arbitrators may authorize the taking of depositions without a commission in the same manner as may be provided by law for the taking of depositions in suits pending in courts of record of this State.

SEC. 6. The arbitrators may, of their own motion and shall by request of a party

(a) at any stage of the proceedings submit any question of law arising in the course of the reference for the opinion of the court stating the facts upon which the question arises and such opinion when given shall bind the arbitrators in the making of their award.

(b) state their final award as to the whole or a part of the reference in the form of a conclusion of fact for the opinion of the court on the questions of law arising and such opinion shall finally conclude the proceeding, except as by this Act otherwise provided.

SEC. 7. The award of the arbitrators, or a majority of them, 
skall be dram up in writing and signed by the arbitrators or a majority of them: the award shall definitely deal with all matters of difference in the submission requiring settlement, but the arbitrators may, in their discretion, make a partial award or amards, which shall be enforceable in the same manner as the final award: upon the making of such award, the arbirators shall deliver a true copy thereof to each of the parties thereto without delay.

SEC. S. If either of the parties neglect to comply with any partial or final amard, made by the arbitrators, the otber party may, at any time within one year from the time of such failure, file sach arard, together with the submission in court.

SEc. 9. The party filing such award may, by giving ten days' notice of his intention to the opposite party, and if no legal exceptions are taken to such award, have judgment theren, as on the rerdict of a jurg; upon any legal exceptions taken, the findings of fact by the arbitrators shall be conclusire; suceessive judgments in the same case may be entered on successive awards of the arbitrators on the subject matter of the submission together with the costs of arbitration and the court, and execution may issue as in other cases.

SEC. 10. Then the award requires the performance of any act other than the payment of money, the court rendering such judgment shall enforce the same by rule, and the party refusing or neglecting to comply with such rule may be proceeded against by attachment or otherwice as for a contempt.

SEC. 11. If any legal defects shall appear in the award or other proceedings, or if it shall appear that the award is not sustainable under the opinions of the court upon questions of law under section 6 of this Act, the court may set aside such award. or remit the matters contained in the said award to the reconsideration of the said arbitrators: or, if it shall appear, on oath or affirmation that said award was obtained by fraud, corruption or otber undue means, or that such arbitrators misbehared, said court may set aside such award.

SEC. 12. If there be any erident miscalculation or misdeseription, or if the arbitrators shall appear to have awarded upon matters not submitted to them, not affecting the merits of the decision apon the matters submitted, or where the award shall be 
imperfect in some matters of form, not affecting the merits of the controrers, and where such errors and defects. if in a rerdict, could hare been lawfully amended or disregarded by the court, any party aggriered roag more the court to modify or correct sucb award.

SEC. 13. Applications to set aside, rowify or amend or remit such arard, as prorided in the sections 11 and 12 of this Act, mast be made before the entry of fnal judgment on sucb award: Protided, nothing herein cortained shall be so construed as to deprive courts of chancers of their jurisdiction, as in other cases.

SEC. 14. Trits of error and appeals zay be taken from any decision of the court upon questions of law under section 6 of this Act, or matters arising in the conrse of the proceedings. by the party feeling himself aggriered, as in other case : and if the case shall be upon such writ of error or appeal remanded. such further proceedings shall be had as the cature of the case may require.

SEc. 15. The parties mar, in the submission, agree upon the amount of compensation to be paid to the arbitrators and the terms of the parment of the same: unless so agreed. each arbitrator shall be allowed. for erery day's attendance to the business of his appointment $\$ 3.00$, to be paid in the frst instance by the party in whose faror the award shall be mace. but to be reoorered of the other pary with the other costs of suit. if the award or final decision shall entitle the prevalling party to recorer costs. Sheriffs, constables, the bailifi of the municinal court of Chicago. clerks and justices of the peace shall be entitled to the sare ifes for services periormed in relation to any arbitration. as shall be allowed br law for the like services in their respective cours.

SEc. 16. Arbitrators may be compelled. by order of the cour:. to proceed to a hearing of the submission and to make repor: without unveressary delar.

Src. 17. In this Act unless the contest or subject matter oiberwise requires.

"Court," means the court nared in the submission. and if no court be named. an! court haring jurisdiction of the subjec: matter. to which application is made or procedings had on a submission.

"Submission" mans a tritten agreement to submit diferences 
to arbitration, whether such differences be in whole or in part in suit or not in suit.

Sec. 18. [Repeal.] An Act to revise the law in relation to arbitrations and awards, approved April 29, 1873, in force July 1, 1873, except as herein reënacted, is hereby repealed, but this section shall not be construed so as to affect any right, actions or causes of action that may have accrued or be pending when this Act shall take effect.

Approved June 11, 1917.

\section{APPENDIX D}

FORM OF ARBITRATION AGREEMENT ADOPTED BY THE PUBLIC SERVICE COMMISSION FOR THE FIRST DISTRICT OF THE STATE OF NEW YORK WITH THE INTERBOROUGH RAPID TRANSIT COMPANY OF NEW YORK

(Vol. IV (1913) Reports of Public Service Commission for the First District, State of New York.)

\section{Chapter VI}

ARBITRATION

Article $X X X$. If the Commission or the Lessee shall desire to submit to arbitration any matter of difference arising under any provision of this contract in respect of which it is therein provided an arbitration may be had, then such matter of difference may be submitted to arbitration. Such arbitration shall be conducted as follows: Either the City, acting by the Commission, or the Lessee, may give written notice to the other that it requires the matter arising hereunder to be submitted to arbitration, and shall at the same time name a disinterested person as an arbitrator, and accompany the notice by a written acceptance by the arbitrator of the nomination. Within thirty (30) days after the receipt of sueh notice, the party receiving the same shall name a disinterested person as an arbitrator, and give written notice of such nomination to the other party, the notice to be accompanied by a written acceptance by the arbitrator of the 
nomination. If the party to whom notice of arbitration is given shall not so nominate an arbitrator, who shall so accept, then the arbitrator named by the party giving the first notice shall be the sole arbitrator. The Commission and the Lessee shall upon the nomination of the second arbitrator select a third arbitrator; but if they fail to agree upon such third arbitrator within thirty (30) days after the date of the nomination of the second arbitrator nominated, the third arbitrator shall be nominated by the Chief Judge of the Court of Appeals of the State of New York; or if within fifteen (15) days after being requested by either the Commission or the Lessee to make such nomination, the said Chief Judge shall decline or fail to make a nomination, then an arbitrator shall be nominated, upon the request of the Commission or the Lessee and within a period of fifteen (15) days by any Associate Judge of said Court of Appeals in order of seniority; or if within such periods the said Judges shall decline or fail to make a nomination, then the third arbitrator shall be nominated by the President or Acting President for the time being of the Chamber of Commerce of the State of New York. The arbitrators shall hear the parties and their counsel or any statements or evidence which the parties or either of them desire to submit. The failure to give the notice provided for in Article XXIX shall not preclude the party failing to give such notice from setting up counterclaims growing out of or incident to the matter as to which the other party shall have given such notice. Either party may, upon two (2) days' notice (Saturdays, Sundays and Holidays excepted) to the other, bring on the subject in dispute for hearing before the arbitrators. Within thirty (30) days after such hearing commences, unless such time shall be extended for good cause by written order of the arbitrators or a majority of them, the arbitrators shall make their determination in writing in duplicate, one to be delivered to the Commission and the other to the Tessee. In case any vacancy shall at any time occur by reason of the death, resignation or inability to serve of any arbitrator, his successor shall be nominated in the same manner and within the same times (during which times the other periods of time prescribed for or in the course of the arbitration shall be suspended) as above provided for in case of the original nomination of such arbitrator and in 
case the successor arbitrator shall not be nominated within such times the remaining arbitrator or arbitrators shall be the sole arbitrator or arbitrators. Any determination by a majority of the arbitrators shall be final and conclusive. Every such arbitrator shall be deemed to be employed both by the City and the Lessee. The fees and expenses of the arbitrators (including necessary expenses for stenographic and clerical services) and the expenses of the parties shall be assessed as the arbitrators consider equitable and as they direct in their award, but such assessments so made shall not be charged to cost of construction, cost of equipment or to operating expenses. Every such arbitrator shall, before proceeding to consider the matter, be sworn as nearly as may be in the same manner as referees in actions at law are required to be sworn.

Provided, however, that if in any case, or for any reason an arbitration cannot valicly be bad as aforesaid, then the City or the Lessee, if in no way responsible for the failure of the arbitration, may bring such action, suit or proceeding as either of them may be advised for the purpose of determining any of the matters for which an arbitration is herein provided.

\section{APPENDIX E}

\section{ARBITRATION PROVISIONS OF UNITED STATES BHIPPING BOARD CHARTER}

\section{Bare BOAT FORM}

Arbitration-Thirteenth-Any dispute of law or fact arising under this "Bare Boat Form," except as to the rate of hire and the compensation for actual or constructive total loss of the vessel and except as to matters expressly left to be decided by the United States Shipping Board, shall be referred to the arbitration of three persons, one appointed by the owner, one by the United States, and the third by the two so chosen. They may proceed in any manner determined by themselves, and their decision, or that of any two of them, shall be final, and for the purpose of enforcing any award hereunder the agreement may be made a rule of court. Such arbitration shall be a condition precedent to the commencement of any action. 


\section{APPENDIX F}

\section{RULES OF THE MUNICIPAL COURT OF CHICAGO GOVERNING ARBITRATIONS}

RULE 22 of The Municipal Court of Chicago. "Upon the filing in this court of any instrument of submission to arbitration of any controversy existing between the parties thereto, with the written consent of the parties to such filing, the court shall take jurisdiction of the parties and subject-matter of such submission without the filing of any praecipe, statement of claim, statement of set-off, affidavit of claim, answer, affidavit of merits or other pleading. From time to time during the pending of such suit, eitler before or after award, any party or arbitrator may submit to the court any matter of law arising in the proceedings before the arbitrators or on the award, and the court shall thereupon give such directions or enter such order affecting matters of law as shall appear to be in accordance with law."

LAW OF I9I7 ON ARBITRATION AND AWARDS. The Arbitration and Awards Act of $\mathrm{rg} 7 \mathrm{r}$ is stated below in abstract form, except where quotation marks show exact copies of the law:

Sec. I. One or more arbitrators may be appointed to hear any existing controversy.

Sec. 2. Contract of submission may dcsignate the number of arbitrators, one or more, as the parties shall agree, the manner in which they may be appointed and vacancies filled, the time and place of hearing and rules for the hearing of the controversy. "The parties to such submission may include by reference in said written submission the published rules of any organization or association, which rules shall thercby become a part of the contract of submission."

Sec. 3. "A submission to arbitration shall, unless a contrary intention is expressed therein, be irrevocable."

Sec. 4. Arbitrators to administer oaths, subpoena witnesses, subpoenas to be served by officer or otber person.

Sec. 5. May take depositions.

Sec. 6. "The arbitrators may, of their own motion and shall by request of a party:

(a) At any stage of the proceedings submit any question of law arising in the course of the reference for the opinion of the court stating the facts upon which the question arises and such opinion when given shall bind the arbitrators in the making of their award.

(b) State their final award as to the whole or a part of the reference in the form of a conclusion of fact for the opinion of the court on the questions of law arising and such opinion shall finally conclude the proceeding, except as by this Act otherwise provided."

Sec. 7. "The award of the arbitrators, or a majority of them, shall be drawn up in writing and signed by the arbitrators or a majority of them; the award shall definitely deal with all matters of difference in the submission requiring settlement, but the arbitrators may, in their discretion, make a partial award or awards, which shall be enforceable in the same manner as the final award; upon the making of such award, the arbitrators shall deliver a true copy thereof to each of the partics thereto without delay.".

Sec. 8. Award may be filed in court within one year.

Sec. 9. "The party filing such award may, by giving ten days' notice of his intention to the cpposite party, and if no legal exceptions are taken to such award, have judgment thereon, as on the verdict of a jury; upon any legal exceptions taken, the findings of fact by the arbitrators shall be conclusive; successive judgments in the same case may be entered on successive awards of the arbitrators on the subject matter of the submission together with the costs of arbitration and the court, and execution may issue as in other cases."

Sec. Io. Court may compel performance of award.

Sec. II. Award may be set aside for error in law or for fraud, corruption or other undue means, or because arbitrators misbehaved.

Sec. 12. Award may be modified or corrected if award is upon matters not submitted.

Sec. I3. Applications to set aside award must be made before final judgment.

Sec. I 4. Writs of error and appeals may be taken from any decision of the court on questions of law as in other cases.

Sec. 15. "The parties may, in the submission, agree upon the amount of compensation to be paid to the arbitrators and the terms of ille payment of the same; unless so agreed, each arbitrator shall be allowed, for every day's attendance to the business of his appointment $\$ 3.00$, to be paid in the first instance by the party in whose favor the award shall be made, but to be recovered of the other party with the other costs of suits, if the award or final decision shall entitle the prevailing party to recover costs. Sheriffs, Constables, the Bailiff of The Municipal Court of Chicago, clerks and justices of the peace shall be entitled to the same fees for services performed in relation to any arbitration, as shall be allowed by law for the like services in their respective courts."

Sec. I6. Court may compcl arbitrators to proceed to hearing and make report without unnecessary delay.

Sec. I 7. The word "court" used in the Act means the court named in the submission or if no court be named, any court having jurisdiction.

" "Submission' means a written agreement to submit differences to arbitration, whether such differences be in whole or in part in suit or not in suit.":

Sec. I8. Old Arbitration act repealed. 


\section{APPENDIX G}

\section{FORM OF SUBMISSION TO ARBITRATION USED IN THE MUNICIPAL COURT OF CHICAGO}

THE MUNICIPAL COURT

STATE OF ILLINOIS,

City of Chicago

and $\ldots \ldots \ldots \ldots \ldots \ldots$

Submission to Arbitration

Submission to Arbitration. No....

WHEREAS, a controversy exists between ...................... and ................ parties to this instrument, which briefly stated is as follows:

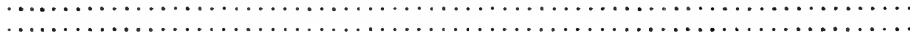

Now, THEREFORE, this agreement, made this ... day of . . . . .

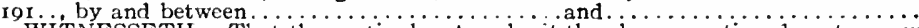

WITNESSETH: That the parties hercto submit the above mentioned controversy to arbitration, and to that end they appoint arbitrator as follows:.............

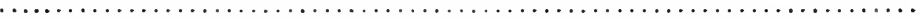

Said arbitrator shall, after having taken the oath as arbitrator in the form attached to this instrument, proceed with all convenient speed to hear the allegations, evidence and arguments of the respective partics hereto. Said arbitrator shall conduct proceedings in all things pursuant to the laws of the State of Illinois and the practice of The Municipal Court of Chicago, Rule 22 of said court being hercby, by reference, included in this submission and made a part hereof.

It is further agreed that this instrument of submission to arbitration may be filed in The Municipal Court of Chicago either by the arbitrator of his own motion or by one of the parties to this instrument, notice thereof being given to all parties to this submission and to said arbitrator, and such filing in said Municipal Court of Chicago shall be deemed a filing with the written consent of the parties to this submission in accordance with law and the practice of said court, and the court shall thereupon take jurisdiction of the parties and subject-matter of this submission without written pleadings, in accordance with the practice of said court.

It is further agreed that a judgment or successive judgments of said Municipal Court shall be rendered upon any award or awards made pursuant to this submission.

It is further agreed that the compensation of said arbitrator shall be as follows:

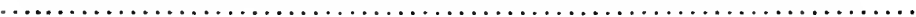

Said compensation shall be taxed as costs and made a part of said judgment in favor of the successful party and against the unsuccessful party.

IN WITNESS WHEREOF the parties hereto have hereunto set their hands and seals the day and year first above written.

(CORPORATIONS MUST ATTACH THEIR CORPORATE SEALS)

\section{OATH OF ARBITRATOR}

\section{STATE OF ILLINOIS, COUNTY OF COOK, City OF CHICAGo.}

I. . . .. who have been appointed arbitrator by the above instrument of submission to arbitration, being duly sworn on oath say that I will faithfully and fairly hear, examine and determine the cause and controversy mentioned in the foregoing instrument of submission to arbitration, according to the principles of equity and justice, and make a just and true award according to the best of iny understanding.

Subscribed and Sworn to before me this...... day of

$$
\left.\begin{array}{l}
\text { A.D. } 191 . . .
\end{array}\right\}
$$




\section{APPENDIX II}

LIST OF TRADE ORGANIZATIONS IN CHICAGO AGREEING TO PROMOTE TRADE ARBITRATIONS

Chicago Stock Exchange.

Chicago Board of Trade.

Chicago Butter and Eggr Board.

The Chicago Masons' and Builder's' Association.

Chicago Master Steam Fitter's' Association.

The Independent Oil Men's Association.

The International Stamp Manufacturing Association.

The Lumbermen's Association of Chicago.

National Association of Chair Manufacturers.

National Association of Steel Furniture Manufacturers.

The Illinois Lumber and Builders' Supply Dealers' Association.

Chicago Bottlers' Clearing House Association.

Chicago Jeweler's' Association.

Chicago Master Plumbers' Association.

The Illinois Bankers' Association.

The International Association of Manufacturing Photo Engravers.

Live Poultry and Dairy Shippers' Traffic Association.

Manufactmrers and Dealers' Association.

National Association of Employing Lithographers.

National Association of Tanners.

National Metal Trades Association.

The Central Supply Association.

Northwest Ladies' Garment Manufacturers' Association.

The Wholesale Clothiers' Association.

American Association of Creamery Butter Manufacturers.

Association of American Portland Cement Manufacturers.

American Garage and Auto Dealers.

Chicago Bar Association.

American Washing Machine Manufacturers Association.

Bridge Builders' Society.

Building Managers' Association.

National Ponltry, Butter and Egg Association.

The Pattern Makers' Association of Chicago. 
Printing Trades Credit Association. American Association of Engineers.

The Carpenter Contractors' Association of Chicago.

Chicago Association of Commerce.

Industrial Club of Chicago.

Building Construction Employers' Association.

Chicago Building Trades Council.

California Vegetable Lnion.

Chicago Coal Merchants' Association.

Chicago Landlords' Ageney.

Chicago Produce Trade and Credit Association.

Credit Bureau Millinery Jobbers' Association.

Employing Plasterers Contractors' Association of Chicago.

Hickory Products Association.

Illinois Society of Architects.

International Association of Rotary Clubs.

Landlords' Association.

Chicago Contracting Team Onners' Association.

Chicago Furniture Manufacturing Association.

Chicago Laundrymen's Association.

Chicago Retail Druggists Association.

Employing Electrotypers' Association.

Fibre Shipping Container Association.

Illinois Manufacturer's' Association.

Illinois and Wisconsin Retail Coal Dealers' Association.

Investment Bankers Association of America.

Chicago Retailers' Association.

Manganese Steel Founder's' Society.

Maple Flooring Mannfacturers' Association.

Master Roofers' Association of Chicago.

Milk Producers' Association.

Motor Truck Owners' Association.

National Association of Adrertising Specialty Manufacturers.

National Association of Retail Druggists.

National Hardwood Lumber Association.

Retail Merehants' Association.

Western Society of Engineers.

Manufacturers and Importers' Association of America. 
Msset: Car Buidess Asmastin.

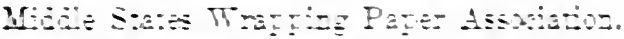

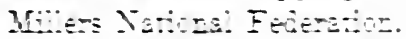

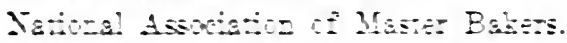

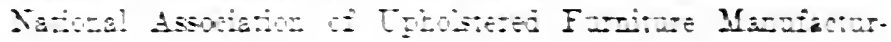
ET.

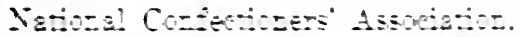

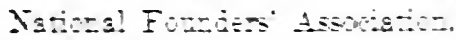

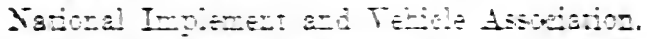

Sigfers Irafe Asinatin.

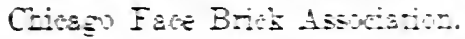

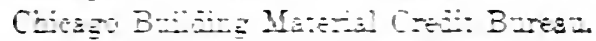

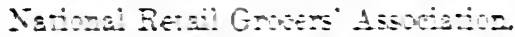

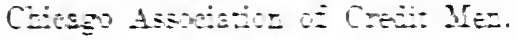

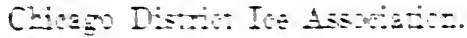

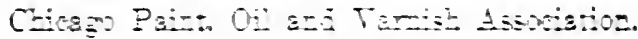

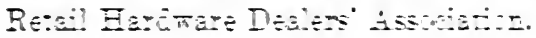

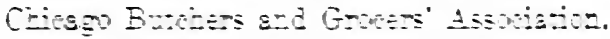

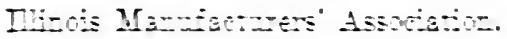

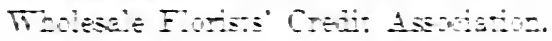

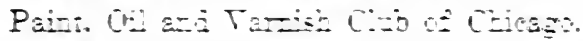

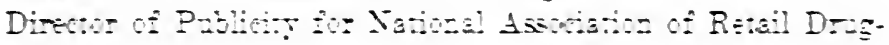
gis:

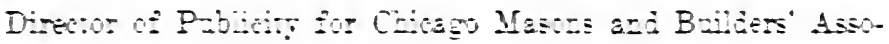
cistion.

Antrias Assotiation of E-zizers.

\section{APPENDIS I}

RLIES FOR AEBITEATION NOT TS OPEDAIION IN TEE WTAICTPAI COLZI OE TEE CIII OE NET TORE

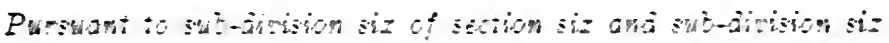

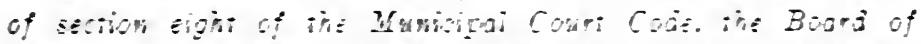

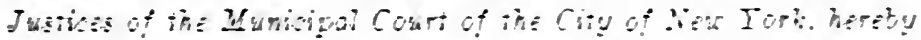

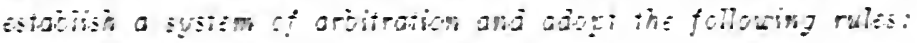




\section{Rule I}

The parties to any controversy, except infants and incompetents, nay submit the same for arbitration to a Justice of this Court or to any other person upon whom they shall agree.

\section{Rule II}

The persons desiring an arbitration shall sign a consent which shall contain the name of the arbitrator, a brief recital of the nature of the controversy to be determined and a statement that they will abide by these rules. The consent must be filed with the clerk of one of the districts, which district shall be the proper district for all further proceedings, and a copy thereof shall be given by the parties to the arbitrator.

\section{Rule III}

The arbitrator shall forthwith proceed to hear the controversy. He shall not be bound by the rules of evidence, but may receive sueh evidence as seems to him equitable and proper. Either party may be represented by counsel, but no record of the proceedings before the arbitrator shall be kept. No expense shall be incurred by him except upon the consent in writing of the parties.

\section{Rule IV}

After the first hearing neither party may withdraw from the arbitration unless both parties consent to, or the arbitrator directs a diseontinuance of the proceeding.

\section{Rule $V$}

The arbitrator shall make his award in writing and file the same forthwith, together with his opinion, if any, with the clerk of the proper district. Unless both parties file a request in writing not to enter julgment, the clerk shall within two days after the filing of the award enter judgment in accordance therewith, provided the award has been filed within thirty days from the date of filing the consent. The time within which the elerk 
shall enter judgment may be extended by a stipulation in writing for a further period of not to exceed thirty days.

\section{Rule VI}

The clerk in each district shall keep a docket wherein proper entries of all proceedings shall be made.

\section{Rule VII}

No fees or disbursements of any kind shall be demanded or received, except as hereinabove provided.

\section{FORMS}

The consent, award and judgment must be in substantially the following form, the blanks being properly filled:

\section{CONSENT}

Municipal Court of the City of New York.

Borough of............... Distriet.

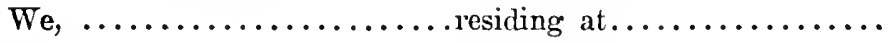

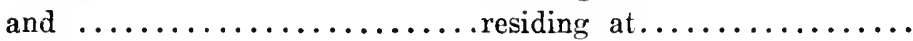
hereby designate

as arbitrator to hear and determine the following controversy existing between us, viz.:

We agree that the arbitrator proceed in accordance with the rules of the Municipal Court of the City of New York and do hereby declare that we know said rules and that we will abide by them. 


\section{AWARD}

I,$\ldots \ldots \ldots \ldots \ldots \ldots \ldots \ldots \ldots$, the arbitrator appointed pursuant to a consent signed by $\ldots \ldots \ldots \ldots \ldots \ldots \ldots \ldots$ and and filed in the office of the Clerk of the Municipal Court for the............ Distriet, Borough of ..................... on the.... day of................, 191..., to hear and determine the controversy therein specified, hereby certify that I have heard the parties to said controversy and the evidence submitted by them and find and decide that

Dated, New York, $\quad 191$

Arbitrator.

\section{JUDGMENT}

Upon the consent filed on the......day of..............

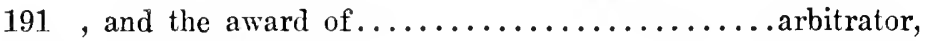
filed on the...... day of............ 191 , judgment is

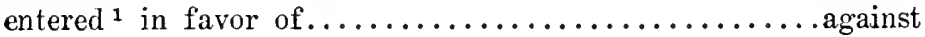
...................... Dollars $(\$ \quad$ ). for the sum of

Dated

Clerk.

${ }^{1}$ Or insert such other judgment in accordance with the award. 


\title{
BIBLIOGRAPHY
}

\author{
General
}

ARISTOTLE: The rhetoric of Aristotle; a translation by Sir Richard C. Jebb, edited by J. E. Sandys. Cambridge: Univ. Press, 1909. 207 p. 24, 25. Cyclopedia of Law and Procedure. Popular ed. William Mack, editor in chief. New York: The Amer. Law B'k Co., 1909-12. $12 \mathrm{v}$.

93.

The Encyclop enda Britannica; a dictionary of arts, sciences, literature and general information. 11th ed. Cambridge: Univ. Press, 1911. 29 v.

$37,84,102,119,132,135,137,154,184,210,212$.

Harvard Law Review. Cambridge: Harvard Law Rev. Assoc. 13.

The Holy Bible, containing the Old and New Testaments.

Oxford: Univ. Press, 1833. $1271 \mathrm{p}$. 280.

London Law Journal. V. 44, Feb. 20, 1909.

London Times: editorial, May 8, 1891.

New York Law Journal. New York: 1888.

New York State Bar Association: Proceedings of the 40th annual meeting, 1917, and reports for 1916. Albany: The Argus Co., 1917. 879 p. 234.

Penny Cyclopedia. London: C. Knight, 1833-43.

$27 \mathrm{v}$. in $14.24,28,29$.

Yale Law Journal. New Haven, Conn., 1890.

40.

\section{AGENCY}

STORY, JOSEPH: Commentaries on the law of agency, as a branch of commercial and maritime jurisprudence. Boston: Little \& Brown, 1839. 544 p. 96. 


\section{ARBITRATION AND $\Lambda$ waRds}

Arbitration as a Condition Precedent. view, Vol. II, Dec., 1888, p. 234.)

(Harvard Law Re202, 226.

Bacon, Matrinew: The Compleat Arbitrator; or, the law of awards ... 3d ed., with precedents of submissions, awards and pleadings in English . . . London, 1770. $281 \mathrm{p}$.

$39,93,279$.

BeLL, John Montgomerie: Treatise on the law of arbitration in Scotland. 2d ed. With an appendix of forms. Edinburgh: T. \& T. Clark, 1877. 460 p.

7, 25-28, 58, 59, 133, 166 .

BILling, S.: A practical treatise on the law of awards and arbitrations, with forms of pleadings, etc. London: 1845.

37.

Chamber of Commerce, N. Y. S., Committee on Arbitration: Report, 1917.

9.

Champlair: L'ami de la Coneorde; ou, Essai sur les motifs d'éviter les procès, et sur les moyens d'en tarir la source. Paris: Monory, 1779. $80 \mathrm{p}$.

31.

Charmolu, A.: La Justice gratuite et rapide par l'arbitrage amiable. Paris: V. Giard et E. Brière, 1898. 128 p. (Petite encyclopédie sociale, économique et financière. v. 25.) 32.

Fletcher, Banister: Arbitrations: a text book for surveyors, in tabulated form. 2d ed. London: B. T. Batsford, 1893. $119 \mathrm{p}$.

34.

Goubeau de la Billénnerie: Traité général de l'arbitrage en matière eivile et commerciale; ou, Recueil complet des règles à suivre tant par les parties que par les arbitres. Tome 1-2. Paris: Renard, 1829-34. 2 v.

Hopkins, Manley: $\Lambda$ handbook of Average, for the use of agents, merchants, ship-owners, masters and others: with a chapter on arbitration, recent decisions in the courts bearing on these subjects. $2 d$ ed. London: Smith, Elder \& Co., 1859 .

34.

Irons, J. C., and R. D. Melville: Treatise on Law of Arbitration in Scotland; with an appendix of forms and excerpts from statutes relating to arbitration. Edinburgh: W. Green and Soll, 1903. 
Kyd, Stewari: $\Lambda$ treatise on the law of awards. Dublin: Printed by J. Stockdale, ete. 1791. $251 \mathrm{p}$.

$$
\text { 29, 30, 31, 93, 94, 105, 107, 114, } 280 .
$$

March, JoHN: Actions for slinder or a methodical collection under certain grounds and heads, of what words are actionable in the law, and what not. To which is added, awards or arbitrements methodised under severall grounds and heads, ete. London: 1647. n.p.

$$
53,54,55,56,57,93,99,106,116,117 .
$$

MonsE, J. T., JR.: The Law of arbitration and award. Boston: 1872.

$38,93,159$.

PARKER, J.: Notes on the Law of Arbitration . . . 2d ed. Edinburgh, 1845.

37.

Rigaud, F.: Expertises et arbitrages. Paris: Gauthier-Villars, [1902 ?] 177 p. (Encyelopédie seientifique des aide-mémoire.-[Sec. de l'ingénieur.])

34.

Rosenbaum, Samuel: A Report on Commercial Arbitration in England, by Samuel Rosenbaum. . . . Oct., 1916. American Judicature Soc. Bul. no. 12. [Chicago]. Chicago Legal News Co., 1916. 3-72 p. 8, 9, 18-23, 245, 253.

WATSON, Sir W. H.: Treatise on the law of arbitrations and awards. Philadelphia: 1836. (Law Lib. v. 11.) 93. WiLson, JoHn: A Short treatise on the law, relative to arbitration. Containing adjudged cases . . Hull: printed for the pub., 1792. $255 \mathrm{p}$. 93.

Wood, J. P., and J. R. N. Macphall: The Law of Arbitration in Scotland. Edinburgh: Bell \& Bradfute, 1900.

37.

\section{Assumipsit}

Ames, J. B.: The history of assumpsit. (Select Essays in AngloAmerican History. V. 3, p. 257-303. Boston: Little, Brown \& Co., 1909.) 66, 67, 68.

\section{BaILMENTS}

Jones, Sir Willian: Essay on the law of bailments. 4th ed., with notes by W. Theobald. London: 1833. 


\section{BAR}

Root, Elinu: The layman's eriticism of the lawyer. (Report of American Bar Assoc. Vol. 39, p. 386-402. Baltimore: The Lord Baltimore Press, 1914.)

\section{BIOGRAPHY}

Campbell, John: Lives of the Chief Justices of England. 3d ed. 4 v. London: J. Murray, 1874.

Foss, Edward: The Judges of England, with sketches of their lives. London: 1848. 9 v.

$$
\text { 123, 134, 135, 136, 142, 143, 255, } 256 .
$$

\section{Commercial Law}

Boucher, P. B.: Consolato del mare, ou, Pardectes du droit commercial et maritime ... d'après l'édition originale de Barcelonne, de l'an 1494. Paris: Chez A. Bertrand, 1808. $2 \mathrm{v}$.

Holdsworth, W. S.: The Law Merchant. (Select Essays in Anglo-American Legal History. V. 1, p. 289-331. Boston: Little, Brown \& Co., 1907.)

Scrutton, T. E.: General survey of the history of the law merchant. (Select Essays in Anglo-American Legal History. V. 3, p. 7-15. Boston: Little, Brown \& Co., 1909.)

$72,73,74$.

Sмiтн, J. W.: A compendium of mercantile law . . 10th ed. edited by J. Macdonell ... and G. Humphreys ... London: Stevens \& Sons, Ltd. 1890. 2 v.

$$
3,4,71,75,76,81,82 \text {. }
$$

\section{Contracts}

Grennhood, E.: The doctrine of public policy in the law of contracts . . . Chicago: Callaghan \& Co., 1886. 860 p. 14. PAGE, W. H.: The law of contracts. Cincinnati: The W. H. Anderson Co., 1905. 60,70 .

Parsons, T.: The law of contracts. 4th ed. Boston: Little, Brown \& Co., 1860. 2 v. 
Pollock: Principles of Contract at Law and Equity. 6th ed. 760 p. London: Stevens \& Sons, 1894.

Slaymakor, G. B.: The Legality of contracts affecting the jurisdietion of Courts. (Central Law Jour. Vol. 58, p. 64.) 17.

\section{Courts}

Civil Judicial Statistics 1912. (Parliamentary Papers, Cd. 7267.) London: Wyman \& Sons, Ltd., 1914. 156 p. 22. Ransom, William L.: The Organization of the Courts for better administration of justice. (Comell Law Quarterly. P. 186261, 264-265. Ithaca, 1917.)

STORY, Joseph: Commentaries on equity jurisprudence, as administered in England and America. 13th ed. by Melville M. Bigelow . . . Boston : Little, Brown \& Co., 1886. 2 v.

ZOUCHe, Richard: The jurisdiction of the Admiralty of England asserted against Sr. Edward Coke's Articule admiralitatis in XXII Chapter of his Jurisdiction of courts. London: Printed for F. Tyton, \& T. Dring, 1663. $152 \mathrm{p}$.

72.

\section{DenMaRK AND Norway}

Catteau Callville: Tableau des États danois envisagés sous les Rapports du Mécanisme Social. Paris: 102. 3v.

29.

\section{ENGLAND}

Domesdar Book: or, the great Survey of England of William the Conqueror, A. D. MLXXXVI. Photo-Zincographed by her Majesty's command, at the Ordnance Survey Office, Soutlampton: Colonel Sir H. James, director. Lat. 35 Pts. 7.

\section{GILDS}

Gross, Chardes: The gild merchant; a contribution to British municipal history. Oxford: Clarendon Press, 1890. 2 v.

4,5 .

\section{INDIA}

Hodgson, B. H.: Miscellaneous essays relating to Indian subjects . . L London: Trübner \& Co., 1850. 2 v.

36. 


\section{INSURANCE}

PARK: A system of the law of Marine Insurances . . 8 8th ed. with considerable additions, by F. Hildyard. London: 1842. $2 \mathrm{v}$.

\section{JAPAN}

Brinklex, Frank: Japran, its history, arts and literature. Boston: J. B. Millet Co. [cop. 1901-02.] 9 v. (Oriental Series. $\mathrm{V}$ 1-8.)

36.

\section{LAW}

Aввот, Everetr V.: Justice and the modern law. Boston: Houghton Mifflin Co., 1913. 299 p.

124.

Blackstone, William: Commentaries on the laws of England.

8th ed. Oxford: Clarendon Press, 177s. 4 v. $65,73$.

Bowen, C. S. Christopher: Progress in the Administration of

Justice during the Victorian Period. (Select Essays in Anglo-American Legal History. Vol. 1, p. 516-557. Boston: Little, Brown \& Co., 1907.)

40.

Brookes Abridgements. Brook, Sir Robert: La graunde abridgement ... 1586. 2 v. in 1. n.t.p. 99, 106, 107, 117. Carter, A. T.: A history of English legal institutions, 4th ed. London: Butterworth \& Co., 1910. $304 \mathrm{p}$.

$$
2,5,7,71,77,75,79,80,81,137 \text {. }
$$

Coke, Sir Edward: The Reports of Sir E. C. New edition with notes and references by I. H. Thomas and I. F. Fraser. 6 v. London: 1826-27.

$85,86,87$.

Evans, W. D.: Collection of statutes. 3d ed. By A. Hammond and T. C. Granger. 10 v. London: 1836.

149.

Fitzherbert, Anthony: Graund Abridgement Collect, In Aedibus Richardi Tottell duodecimo Nonembris, 1565. Cum priuilegio.

$99,106$.

Glanville, Ranulf DE: Tractatvs de legibus \& consuetudinibus regni Angliae, tempore regis Henrici Secundi compositus, iusticial gubernacula tenente illustri, Et illas solum leges continet \& consuetudines secuudum quas placitatur in Curia regis ad seaccarium \& coram iusticijs vbicunque fuerint. [Londini] in aedibus Thomae Wight, 1604. 116 numb.

Hall, R. S.: Law and Logie. (Illinois Law Review, Vol. XII, 
No. 1, p. 14. May, 1917. Chicago: The Northwestern Univ. Law Pub. Assoe.)

50.

Holdswortir, W. S.: A history of English law. London:

Methuen \& Co., 1903.

259.

Holmes, O. W., JR.: The Common law. Boston: Little, Brown \& Co., 1881. 422 p. 41, 66, 108, 109. Kent, James: Commentaries on Ameriean law. 13th ed. Boston: Little, Brown \& Co., 1884. $4 \mathrm{v}$.

42,47 .

Pollock, Sir Frederick, and F. W. Matriand: The History of

English law before the time of Edward I. (2nd ed.) Cambridge: Univ. Press, 1903. 2 v. 60, 61, 69, 84, 85. REeves, JoHn: Reeves' History of the English law, from the time of the Romans to the end of the reign of Elizabeth [1603]. A new American ed. Philadelphia: M. Murpliy, 1880. $5 \mathrm{v}$. $254,255$.

ScotT, H. W.: The evolution of law, a listorical review from the earliest known history of mankind to the present era. 4th ed. New York: The Borden Press Publishing Co., 1908. $25-165 \mathrm{p}$. 280.

Select Essays in Anglo-American Legal History by various authors. Compiled and edited by a Committee of the Association of American Law Schools. Boston: Little, Brown $\&$ Co., 1907. 3 v.

137.

Soule, C. C.: The lawyer's reference manual of law books and citations. $2 \mathrm{~d}$ thousand. Boston: C. C. Soule, 1884. 497 p. 87, 136.

Statham's Abridganent of the Law. Translated by Margaret C. Klingelsmith. Boston: Boston Book Co., 1915. 2 v. 84, 87, 99, 105, 106, 108.

Viner, Charles: General Abridgment of law and equity, with notes and references. Aldershct in Hampshire near Farnham in Surrey. 1745. $23 \mathrm{v}$.

101, 128, 129.

\section{Legal Maxims}

BROosr, Herbert: A selection of legal maxims, classified and illustrated, 7th American, from the 5th London ed. Pliladelphia: T. \& J. W. Johnson \& Co., 1874. 993 p. $\quad 40,47$. 


\section{Municipal Courts}

Lauer, E. J.: The New Practice and Procedure in the Municipal Court of the City of New York. New York: Baker, Voorhis \& Co., 1916. 1069 p.

$5,7$.

\section{Negotiable Instruments}

Chalmers, Sir Mackenzie D. E. S.: A digest of the law of bills of exchange, promissory notes and eheques, and negotiable secmities. 6th ed. London: Stevens \& Sons, Ltd., 1903. $440 \mathrm{p}$.

72.

Cranch, IV.: Promissory Notes before and after Lord Holt. (Select Essays in Anglo-American Legal History. V. 3, p. 72-97. Boston: Little, Brown \& Co., 1909.) 138, 139.

\section{Persia}

Curzon, G. N.: Persia and the Persian question. London : 1892. 2 v.

\section{REPORTS}

Bracton's Note Book. A collection of cases decided in the King's Courts during the reign of Henry the Third, annotated. Edited by F. W. Maitland. 3 v. Cambridge: [printed], 1887. 67, 73, 103, 104. Cary, R.: Le necessarie use and fruit de les pleadings, conteine en'le lieur de le tres reverend Edward Coke. Londimi: In ædibus Thomæ Wight, an Dom. 1601. Cum privilegis.

CORPUS JURIS; being a complete and systematic statement of the whole body of the law as embodied in and developed by all reported decisions, edited by $\mathrm{Wm}$. Mack \& W. B. Hale. New York: Amer. Law Book Co., 1916. 15 v. 15.

KELYNG, SIR JOHN: Report of Divers cases in pleas of the crown, adjudged and defermined in the reign of the late King Charles II with directions for justices of the peace. Dublin: P. Byrne, 1789. 151 p. 101. Law Thmes Reports. Iondon: 1871-etc. $22,29$. Monkrn Reports, or select cases adjudged in the courts of 
Kings Bench, Chancery, Common-Pleas, and Exchequer, since the Restamration of His Majesty King Charles II. London: T. Basset, 1682. 314 p.

139. Rolle, Henry: Un Abridgment des plusieurs Cases et resolutions del common Ley, ovesque un table des general titles contenus en ceo. London: 1668. '2 v.

128.

Selden Societr: Select pleas in manorial and other seignorial

Courts, edited by F. W. Maitland. London: Bernard Quariteh, 1889. (Vol. 1. Reigns of Henry III and Edward I.) $214 \mathrm{p}$.

3.

The Solicitor's Journal and Reporter. London: 1857, ete.

Veeder, Van Vechten: The English Reports 1537-1865. (Select Essays in Anglo-American Legal History. V. 2, p. 123168. Boston: Little, Brown \& Co., 1908.)

121, 122, 137, 138, 139, 140, 141.

\section{YEAR BOOKS}

Ames Foundation Year Book: Year Book of Richard II ... ed. for the Ames Foundation by Geo. F. Deiser . . . Cambridge: Harvard Univ. Press, 1914.

112. Holdsworth, W. S.: The Year Book. (Select Essays in AngloAmerican Legal History. V. 2, p. 96-122. Boston: Little, Brown \& Co., 1908.) $118,119$.

Year Books of the Reign of King Edward the First-years $\mathrm{XX}$ and XXI. Edited and translated by Alfred J. Horwood. London: Longmans, Green, 1866. 509 p. 118.

Les Reports des Cases argue et adjudge in Le temps del Roy EDWARD LE SECOND et auxy memoranda del Exchequer en temps le Roy Edward le Primer. London: Atkyns, 1678. $685 \mathrm{p}$. and index. $119,121$.

Selden Society: Year Books of Edward II, edited by F. W. Maitland. London: Bernard Quaritch, 1903. 9 v. 53. Soule: Year Book Bibliography. (Harvard Law Review, Vol. XIV, no. 8, Apr., 1901, p. 557-587.) 


\section{TABLE OF STATUTES}

PAGES

English Arbitration Act, 1889. .196, 212-213, 220, 221, 223, 224 English Common Law Procedure Act 1854.... 196, 198, 199, 201 English Ordinance: Rymer's Foedera, i. $75 \ldots \ldots \ldots \ldots .225$ Statute-13 Edw. 1, Chapter 24................ 62

20 Edw. III, Chapter 1............. 258

$27 \mathrm{Edw}$. III, Statutes II, Ch. 21..........77, 78

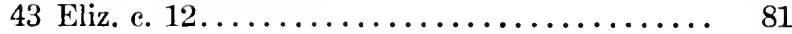

$3 \& 4$ Wm. 4, c. $42 \ldots \ldots \ldots \ldots \ldots \ldots \ldots 180,190,196$

$8 \& 9 \mathrm{Wm}$. III $\ldots \ldots \ldots \ldots \ldots \ldots \ldots \ldots . \ldots \ldots, 149,151$

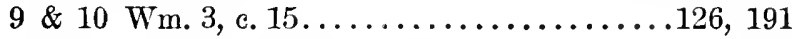

France: Code de Procédure Civil (modern).......... 27

France: Royal Ordonnance (1673), Title IV, Art. 9.... 27 Illinois Law of Arbitration, June 11, 1917.........294-298 New York State. Code of Civil Procedure, Chapter 17,

Title VIII............249, 292-294

Laws 1909, Ch. 45, Sec. 44, as amended by L. 1914, Ch. $507 \ldots \ldots \ldots \ldots \ldots 43$

Laws 1874 , c. $278 \ldots \ldots \ldots \ldots \ldots \ldots$. 6

1875 , c. 495 , sec. $6 \ldots \ldots \ldots \ldots$. 6

1878 , с. $252 \ldots \ldots \ldots \ldots \ldots \ldots \ldots 6$

Scotland Law of Arbitration................. 28

Railway Clauses Consolidation Act, 1845...... 191

United States. Comp. Stat. 1916, Sec. 10165, Sec. 10295. 46

Rev. Stat. Sec. $5392 \ldots \ldots \ldots \ldots \ldots \ldots .46$

35 Stat. at L. 1088, Chap. $321 . \ldots \ldots \ldots \ldots \quad 46$ 


\section{TABLE OF CASES}

Adinolfi $v$. Hazlett, 242 Pa. 25, 88 Atl. 869.......... 13

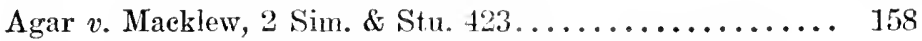

Ames $v$. New York Union Ins. Co., 14 N. Y. 253, 262.... 17

Anderson v. Erie R. R. Co., 171 App. Div. 687......... 18 Aston $v$. George (1819), 2 B. \& Ald. 395........84, 126, 168, $183,226,227$

Auriol $v$. Smith, Turn. 127................. 157

Austrian Lloyd Steamship Co. $v$. Gresham Life Assurance

Society, L. R. [1903] 7 K. B. D. 249, 72 L. J. (K. P)

211,88 L. T. R. 6.........17, 217, 220, 228, 245, 275

Awards, in matter of deliverance of, 3 Croke, 577-8...... 102

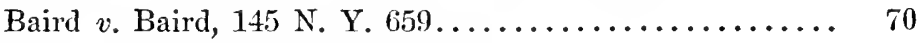

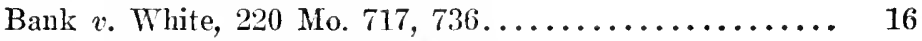

Barlow v. Ocean Ins. Co., 4 Met. 270............... 14

Belcher v. Roedean School Site \& Buildings Limited, 85

L. T. R. 468 (1901) . . . . . . . . . . . . . 215, 228

Belfield $v$. Bourne (1894), 8 R. 61 (1894), L. R. [1894] 1

Ch., 63 L. J. (Ch.) 104.................. 215

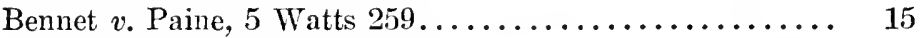

Benson $v$. Eastem Building and Loan Assoc., 174 N. Y.

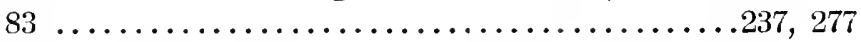

Benson $v$. United States, 146 U. S. 325, 36 I. ed. 991, 13

Sup. Ct. Rep. 60...................... 46

Bertles $v$. Nunan, 92 N. Y. $152(1883) \ldots \ldots \ldots \ldots \ldots \ldots \ldots \ldots .48$

Bishop $v$. Bishop, 15 Car. 1, f. 59, 1641............ 134

Brakinrig $v$. Menzies, 4 Sess. Cases, 2nd Series, 274.... 166, 179

Blaunstein v. Accidental Death Ins. Co., 101 Eng. Com.

Law R., 783, 1 Best \& Smith 782, 50 N. Y. 250... 184, 227, 228, 229, $2: 31$

Bremner v. Elrler, 2 Sess. Cases (4th Ser.) 136......199, 227

Bridgman's Case, Hob. 11................. 82

Bright $v$. Gibson, 32 T. I. R. 533...........223, 272 


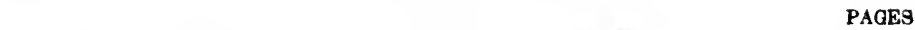

Brocklehurst \& Potter Co. v. Marsch, 225 Mass. 3....... 277 Brode $v$. de Ripple (1375). 49 Ed. III, 8 \& 9.....124, 146, $147,205,226$

Brown v. Overbury, 11 Exch. Rep. $715 \ldots \ldots \ldots \ldots \ldots \ldots \ldots$

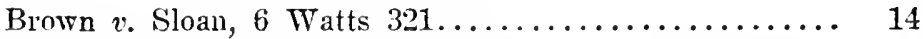

Browne v. Downing, 2 Rolle's Reports.......143, 205, 206, 226 Burton $v$. Ellington, 3 Brown's Rep't. H. C. of Chancery.. 155 Calcraft $v$. Roebuck, 1 Vesey, Jr. 221............. 95 Caledonian Ins. Co. v. Gilmour, L. R. [1893] App. Cas. 85 .209, 228

Caledonian Railway Co. v. Greenock and Wemyss Bay Railway Co., 10 Sess. Cases (3rd Ser.) (1871-2), 892... 191, 227,264

Calvin, case of. 7 Rep. 4 a................... 140 Calvin $v$. Provincial Insurance Co., 27 Up. Can. Q. B. 403.. 15 Came v. Moye, 2 Sid. $121 \ldots \ldots \ldots \ldots \ldots \ldots \ldots \ldots \ldots \ldots \ldots$ Cameron v. Cuddy, L. R. [1914] A. C. $651 \ldots \ldots \ldots 223,228$ The Cap Blanco, 83 L. J. (P.) 23 (1913) ; 109 L. T. R. 672 ; 29 T. L. R. 557. Evans, P. Appeal withdrawn.

See 83 L. J. (P.) 23, C. A..............220, 228

Contra a Carpenter. Y. B. 2 Hen. IV., 3 b. \& 4...... 64 Christie $v$. Noble, L. R. 14 Ch. D. 203............. 202 Church-rate, in matter of. 1 Lofft's Rep. 426......... 129 Clapham $v$. Higham, 1 Bingham $87 \ldots \ldots \ldots \ldots \ldots . \ldots 127,252$ Clark $v$. Gamwell, 125 Mass. $428 \ldots \ldots \ldots \ldots \ldots \ldots \ldots .15$ Clark v. Hamburg-American Packet Co. (1913) (unpublished) 249

Clemens v. American Fire Ins. Co., 70 App. Div. 435.... 17 Clerke v. Martin, Cranch: "Promissory Notes Before and After Lord Holt"....................... 138 Collins $v$. Locke, L. R. 4 App. Cas. 674..........203, 227 Collins $v$. Oliver, 4 Humph. (Tenn.) $439 \ldots \ldots \ldots \ldots \ldots \ldots \quad 57$ Couldery $v$. Bartrum, 19 Ch. Div. $399 \ldots \ldots \ldots \ldots \ldots \ldots .138$ Curtis v. Gokey, 68 N. Y. $300 \ldots \ldots \ldots \ldots \ldots \ldots \ldots \ldots .235$ Daley $v$. People's Building, Loan \& Saving Assoc., 178

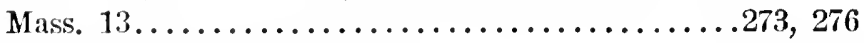
Javila $v$. Almanza, 1 Salk. $73 \ldots \ldots \ldots \ldots \ldots \ldots \ldots 145,197$ Davis $v$. Getty, Sim. \& Stu. $414 \ldots \ldots \ldots \ldots \ldots \ldots \ldots \ldots \ldots$ 


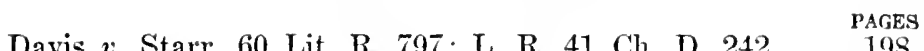
.198, 215,227

Dawson v. Fitzgerald, L. R. 1 Exch. D. 257......193, 195, 212, $227,245,277$

Dawson $v$. Sadler, 1 Sim. \& Stu. 541.............. 157 Delaware \& Hudson Canal Co. v. Pennsylvania Coal Co., 50

N. Y. 250 (Weleh v. Probst 151 App. Div. 147. 1912). 13, $15,70,228,232,235,238,244,249$

Dike $v$. Erie Railway Co., 41 N. Y. 113, 116; 45 N. Y.

$113,116 \ldots \ldots \ldots \ldots \ldots \ldots \ldots \ldots \ldots \ldots \ldots \ldots, 241$

Dimsdale $v$. Robertson, 2 Jones \& La Touche's Reports 58. 157, $166,169,175,190,197,205,206,222,227,233,239,243$

Doleman \& Sons $v$. Ossett Corporation, L. R. [1912] 3 K.

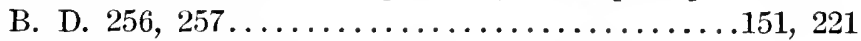

Doyle v. Continental Insur. Co., 94 U. S. 535, 24 L. Ed. 148244 Drew $v$. Drew, 2 Macqueen's Cases on Appeal (Seotch, $1855) \quad \ldots \ldots \ldots \ldots \ldots \ldots \ldots \ldots \ldots \ldots . \ldots \ldots, 180,190,227$

Edwards $v$. The Aberayron Mutual Ship Insurance Society

(Limited), L. R. 1 Q. B. D. 563, 34 L. T. R. 457 ... 192, $195,211,214,219,221,227,277$

Egerton $v$. Brownlow, 4 H. L. C. $1 \ldots \ldots \ldots \ldots \ldots \ldots .14,177$

Eichner $v$. Bowery Bank, 24 App. Div. 63 ......... 45

Eliot National Bank $v$. Beal, 141 Mass. $566 \ldots . \ldots \ldots \ldots .273$

Elliott v. Royal Exchange Assurance Co., L. R. 2 Exch.

237 .......................189, 193, 195, 227

Engel $v$. Shubert Co., N. Y. Supreme Court, App. Div., 1st

Department, 166 App. Div. 394, V. 3071 Bar Assoc.

Reports ..........................17, 278

Erie R. R. Co. v. Stone, 37 Sup. Ct. Rep. $633 \ldots \ldots \ldots \ldots .17$

Exparte Luey, 21 E. L. \& E. 199.................. 15

Fahs $v$. Darling, 82 Ill. 142................... 16

Fetherstone $v$. Cooper (1803) Per Lord Ch. Eldon, 9 Vesey,

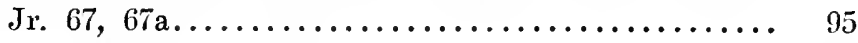

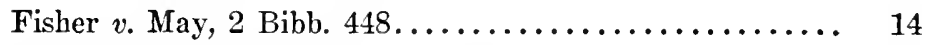

Flamnagan $v$. Kilcome, 58 N. H. $443 \ldots \ldots \ldots \ldots \ldots \ldots . . . \ldots$

Foakes v. Beer, 9 App. Cas. 605................ 137

Fox $v$. The Railroad, 3 Wall. Jr. $243 \ldots \ldots \ldots \ldots \ldots \ldots .15$

Fraser $v$. Ehrensperger, L. R. 12 Q. B. D. $310 \ldots \ldots .196,197,227$ 
Fudickar $v$. Guardian Mutual Life Ins. Co., 62 N. Y. 392.. 234

Fullam $v$. N. Y. Ins. Co., 7 Gray $61 \ldots \ldots \ldots \ldots \ldots \ldots, 18$

Gage, Case of, 5 Rep. 45b; see 1 Salk. 53, and Will. 569... 137

Gaw $v$. British Law Fire Ins. Co., [1908] 1 I. R. 245. ...195, 214

$218,221,228$

The Genesee Chief $v$. Fitzhugh, 12 Howard $443 \ldots \ldots \ldots .42$

Gifford $v$. Livingston, 2 Denio $392 \ldots \ldots \ldots \ldots \ldots \ldots \ldots$

Godfrey $v$. Moser, 66 N. Y. $250 \ldots \ldots \ldots \ldots \ldots \ldots \ldots \ldots$

Gould $v$. The Hudson River Railroad Co., 6 N. Y. 522

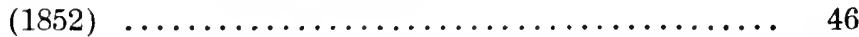

Gourley $v$. Duke of Somerset, 19 Ves. $431 \ldots \ldots \ldots \ldots .158$

Grand $v$. Livingston, 4 App. Div. 589, 593, 596, affirmed 158

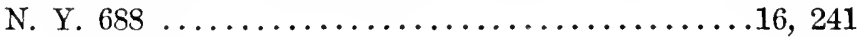

Greason $v$. Keteltas, 17 N. Y. $491 \ldots \ldots \ldots \ldots \ldots \ldots \ldots \ldots 239$

Green $v$. Price, 13 M. \& W. $695 \ldots \ldots \ldots \ldots \ldots \ldots \ldots \ldots \ldots . \ldots \ldots$

Greer $v$. Poole, L. R. 5 Q. B. Div. $272 \ldots \ldots \ldots \ldots \ldots \ldots \ldots 16$

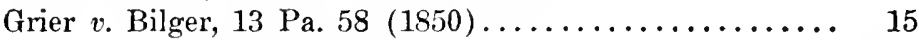

Gumm $v$. Hallett, L. R. 14 Eq. $555 \ldots \ldots \ldots \ldots \ldots \ldots \ldots . \ldots \ldots$

Haggart $v$. Morgan, 5 N. Y. (1 Seld.) 422.......... 237 Halfhide $v$. Fenning, 2 Brown's Chancery Cases 336 (1788),

$156,157,162,163,166,169,170,172,175,197$, $205,206,207,208,222,227,233,239,266$

Hall $v$. People's Ins. Co., 6 Gray $185 \ldots \ldots \ldots \ldots \ldots \ldots \ldots 277$

Hamilton $v$. Ins. Co., 136 U. S. $242 \ldots \ldots \ldots \ldots \ldots \ldots \ldots .70$

Hamlyn \& Co. v. Talisker Distillery, 21 Sess. Cases (4th

Series) 21, L. R. (1894 )A. C. 202

$208,217,223,228,232,239,245,249,263,267-271$

Harcourt $v$. Ramsbottom, 1 Jac. \& Walk. 505, 511

$158,167,168,172,174,190,197,205,206,222$,

$227,239,245,248$

Harris $v$. Reynolds, 7 Q. B. $71 \ldots \ldots \ldots \ldots \ldots \ldots \ldots \ldots, 222$

Harrison $v$. Wright, 13 East $343 \ldots \ldots \ldots \ldots \ldots \ldots \ldots \ldots \ldots$

Hawkins $v$. Colclough, 1 Burrow 275............ 129

Hepburn $v$. Griswold, 8 Wall. 603............. 42

Hertz $v$. Woodman, 218 U. S. $205 \ldots \ldots \ldots \ldots \ldots \ldots \ldots, 42$

Hicknan $v$. Sawyer, 216 Fed. Rep. $289 \ldots \ldots \ldots \ldots \ldots \ldots .18$

Hide v. Petit, Freeman's C'u. Rep. 133; 1 Ch. Cas. 185, 1670;

Netson's Ch. Rep. S3, 1673.....132-134, 165, 183, 206, 227 
Horner $v$. Flintoff, 9 M. \& W. 678.

Horton v. Sayer, 4 Hurlstone \& Norman, 642, 643

$182,185-187,194,201,227,228,239,277$

Hoste $v$. Dalton, 137 Mich. $522 \ldots \ldots \ldots \ldots \ldots \ldots \ldots .16$

Insurance Co. v. Morse, 20 Wall. 445, 22 L. Ed. 365

Isaacs v. Third Avenue Railroad Co., 47 N. Y. 122 (1871);

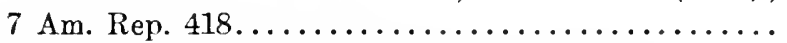

Jackson $v$. Barry Railway, L. R. [1893] 1 Ch. D. 238 (The

Justice of the Peace, Lond. Je. 24, 1911, Vol. 75, P.

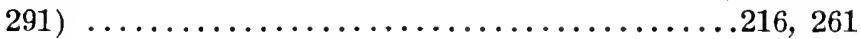

Johnson v. Machielson, 3 Camp. 44 (1811) ........... 276

Jones $v . \longrightarrow, 1$ Rolle $380 \ldots \ldots \ldots \ldots \ldots \ldots \ldots \ldots . \ldots . \ldots . \ldots 143$

Joplin $v$. Postlethwaite, 61 L. T. R. $629 \ldots \ldots \ldots \ldots \ldots . .215$

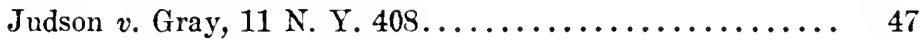

Kemble $v$. Farren, 6 Bing. $141 \ldots \ldots \ldots \ldots \ldots \ldots \ldots . \ldots . \ldots . \ldots$

Ketchum $v$. Belding, 58 App. Div. 295............ 17

Kharas $v$. Collier, Ine., 171 App. Div. $388 \ldots \ldots \ldots \ldots \ldots .45$

Kill v. Hollister, 18 Geo. II 1746, 1 Wils. 129......153-154, 156, $160,170,183,190,206,226,227,239,251,262,266$

King $v$. Joseph (1814), 5 Taunt. $452 \ldots . .84,157,158,167,168$ $183,188,206,226,227,252$

Kirchner \& Co. v. Gruban, 99 L. T. Rep. 932; L. R. [1909]

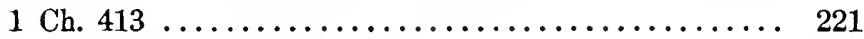

Klein $v$. Maravelas, 219 N. Y. $383 \ldots \ldots \ldots \ldots \ldots \ldots \ldots . \ldots . \ldots . \ldots$

Knox v. Lee, 12 Wall. 457, reversing Hepburn v. Griswold,

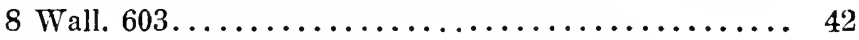

La Greve $v$. Etna Live Stock Ins. Co., 81 Hun 28...... 17 Law v. Garrett, 38 L. T. Rep. 3; 8 Ch. Div. $26 \ldots \ldots . .217,220$ Le Breton $v$. Miles, 8 Paige $261 \ldots \ldots \ldots \ldots \ldots \ldots . \ldots 16,241$

Leavitt \& Lee $v$. Morrow, 6 Ohio St. $71 \ldots \ldots \ldots \ldots . . . .50$

Lee $v$. Page, Law Journal, n. s. vol. 30, Pt. 1........188, 227 Lickbarrow v. Mason, 2 T. R. 63, 1 Smith's L. C., 11th ed., $693 \ldots \ldots \ldots \ldots \ldots \ldots \ldots \ldots \ldots \ldots \ldots \ldots \ldots \ldots \ldots \ldots \ldots \ldots \ldots, 72$

Logan v. Bank of Scotland, 94 L. T. Rep. 153; (1906) 1

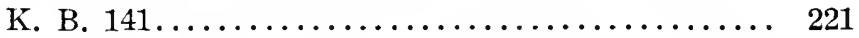

Logan $v$. United States, 144 U. S. 263-301, 36 L. ed. 429-

442,12 Sup. Ct. Rep. $617 \ldots \ldots \ldots \ldots \ldots \ldots \ldots \ldots$ 46 
London Tramways Co. v. Bailey, L. R. 3 Q. B. D. $217 \ldots 201,227$ Lord Lonsdale $v$. Littledale, 2 Vesey, Jr. 451, 452 (1794).

Per L. Ch. Loughborough................ 95

Love-day, in re. Y. B. 21 Ed. III, $7-20 \ldots \ldots \ldots \ldots \ldots .68$

Lowe $v$. Peers, 4 Burr. 2225; 1 Saund. 58c.......... 149

Luke $v$. Lyde, 2 Burr. $883 \ldots \ldots \ldots \ldots \ldots \ldots \ldots \ldots \ldots \ldots \ldots$

MeAllister $v$. Smith, 17 Ill. 328, 334...........16, 241

MeCaul v. Monkland Railway Co., 9 Sessions Cases, 1st

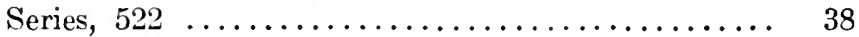

Maekenzie $v$. Girvan, 3 Sessions Cases, 2nd Ser., 318;

2 Bell's App. $43 \ldots \ldots \ldots \ldots \ldots \ldots \ldots \ldots \ldots \ldots 76,166,178$

M'Lean v. Clydesdale Bank, L. R. 9 Appeal Cas. 95....... 73

Manehester Ship Canal Co. v. S. Pearson \& Son, Limited,

Per Contra, Q. B. Div. C. A., L. R. Q. B. D. 1900,

Vol. II, at $606 \ldots \ldots \ldots \ldots \ldots \ldots \ldots \ldots \ldots \ldots \ldots \ldots \ldots \ldots$. 245

Masterson $v$. Masterson, 22 Ky. L. Rep. 1193, 60 S. W.

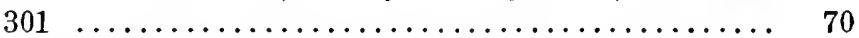

Mayor of New York v. Hamilton Fire Ius. Co., 39 N. Y. 4517 Meacham v. Jamestown, F. \& C. R. R. Co. (1914), 211 N. Y.

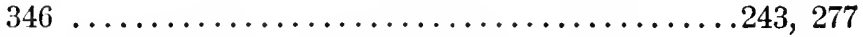

Meeker $v$. Wright, 76 N. Y. $262(1879) \ldots \ldots \ldots \ldots \ldots \ldots \quad 48$

Message Pliotoplay Co. v. Bell, 100 Mise. 267, 167 N. Y.

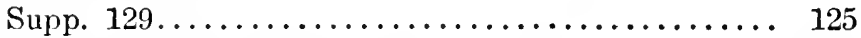

Miles $v$. Schmidt, 168 Mass. $339 \ldots \ldots \ldots \ldots \ldots \ldots \ldots \ldots .273$

Mill, in the matter of. Y. B. 11 Hen. IV., 33......... 64 Mills $v$. Bayley, 2 H. \& C. $36,41 \ldots \ldots \ldots \ldots \ldots 16,187,190$, $192,202,227,228,247$

Mills v. Lee, 6 Monr. $91 \ldots \ldots \ldots \ldots \ldots \ldots \ldots \ldots \ldots$ Milne $v$. Gratrix (1806), 7 East. 608, 611.....84, 126, 157, 158, $167,168,183,188,206,226,227,252$

Mitchell $v$. Harris (1793), 2 Vesey Jr.'s Reports 129

153, 155, 157, 160, 166, 169, 222, 226, 227, 237, 239, 251

Mittenthal $v$. Maseagni, 183 Mass. 19,66 N. E. 425,60

L. R. A. 812, 97 Am. St. Rep. 404....17, 246, 272-274 Moffat $v$. Cornelius, 26 Weekly Reporter 1914.......200, 227 Monongahela Navigation Co. $v$. Fenon (1842), 4 Watts \&

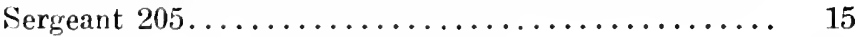

Moore $v$. Fitzwater, 2 Rand (Va.) $442 \ldots \ldots \ldots \ldots \ldots \ldots, 15$ 
Morris $v$. Creach, 22 Car. II, B. R. (1671), 1 Levinz's Rep.

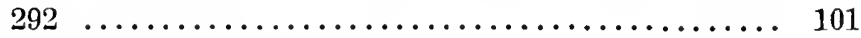

Morse $v$. Goold, 11 N. Y. $281 \ldots \ldots \ldots \ldots \ldots \ldots \ldots . \ldots 47$

Motion Pieture Patents Co. v. Universal Film Mfg. Co.,

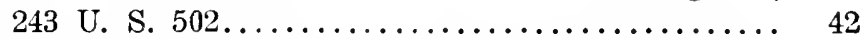

Mounteagle v. Penruddock, Godbolt's Reports (1613), p. 185, Y. B. 20 H. 6. 18 (1442) ..............98, 99, 100

Muldrow $v$. Norris, eontra, 2 Cal. $74 \ldots \ldots \ldots \ldots \ldots \ldots .16$

N. Y., L. \& W. R. R. Co., Matter of, 98 N. Y. $447 . . . . .17$

Newgate $v$. Degelder, 18 Car. II, 1 Sid. 281, 2 Keble's Reports, $10,20,24 \ldots \ldots \ldots \ldots \ldots \ldots \ldots \ldots \ldots \ldots . . \ldots \ldots$

Noble $v$. Harris, 3 Keble's Reports 745,29 Car. II B. R.

1688 ...............................145-146

Northampton Gas-Light Co. v. Parnell, 15 C. B. 630, 645,

80 E. C. L. 630, 139 English Reprint 572....16, 180, 227, 247

Northern Liberty Market Co. v. Kelley, 113 U. S. 199... 70

Norton v. Mascall, 36 Car. 2; Repts. of Cases in Ch. Vol.

II, p. 304 (1694) ............134-135, 137, 205, 206, 274

Nute v. Hamilton Mut. Ins. Co., 6 Gray $174 \ldots \ldots \ldots \ldots 14,277$

O. \& L. C. R. R. Co. v. V. \& C. R. R. Co., 63 N. Y. $176 \ldots 16$

The Oranmore, 24 Fed. Rep. $922 \ldots \ldots \ldots \ldots \ldots \ldots \ldots .241$

Oregon, ete., Bank v. Amer., ete., Co. (C. C.), 35 Fed. 22. . 244

Pacific Insurance Co. $v$. Soule, 7 Wall. $433 \ldots \ldots \ldots \ldots . .442$

Pakas $v$. U. S. See Rosen $v$. U.S.

Palmer $v$. Lavers, 105 N. E. 1000 (Mass. Supreme Jud. Ct. 1914)

Pearson \& Son, Ltd., v. Dublin Corp., L. R. [1907] A. C. 351

222

Penn $v$. Lord Baltimore, 1 Ves. Sen. $444 \ldots \ldots \ldots \ldots \ldots . .14$

People $v$. Charles Schweinler Press, 214 N. Y. 395....43, 278

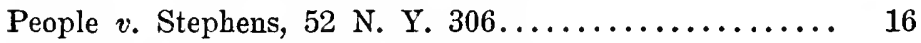

People $v$. Williams, 189 N. Y. $131 \ldots \ldots \ldots \ldots \ldots \ldots \ldots . . .64$

Perkins v. U. S., ete., Co. (C. C.), 16 Fed. 513........ 244

Philadelphia, etc., Co. v. Davis, etc., Co., 77 Fed. $879 \ldots \ldots \quad 70$

Phillip $v$. Phillip, 160 N. Y. Supp. 624, 96 Mise. $471 \ldots . .994$

Pieree $v$. Somerset Railway, 171 U. S. $641 \ldots \ldots \ldots \ldots \ldots .68$

Pierey $v$. Young, L. R. 14 Ch. D. 200...........202, 227

Pierson $v$. McCahill, 21 Cal. 122................. 15 
PAGES

Pillans $v$. Van Mierop, 3 Burrow, $1663,1669 \ldots \ldots \ldots \ldots 6,80$ Pinnell, ease of. 5 Rep. 117a; Co. Litt. 212b. See Foakes

v. Beer, 9 Аpp. Cas. $605 \ldots \ldots \ldots \ldots \ldots \ldots \ldots \ldots 137$

Pollock $v$. Farmers' Loan \& 'Trust Co., 157 U. S. 429, revers-

ing Springer $v$. United States, 102 U. S. 586, and Pa-

cific Insurance Co. $v$. Sonle, 7 Wall. $433 \ldots . . . \ldots \ldots 42$

Pope v. Lord Duneannon, 9 Sim. 177.............168, 248

President, ete., of Delaware \& Hudson Canal Co. See Dela-

ware \& Hudson Canal Co.

Price $v$. Williams, 3 Bro. C. C. 163; 1 Vesey Jr. 365. ...162, 207 Printing and Numerical Registering Co. $v$. Sampson, L. R.

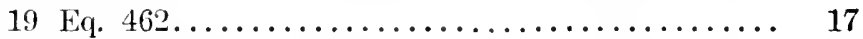

Randell $v$. Thompson, L. R. 1 Q. B. D. $748 \ldots . .192,197,201,227$

Rastetter $v$. Hoenninger, 214 N. Y. $66 \ldots \ldots \ldots \ldots \ldots \ldots 9$

Reed $v$. Washington Fire \& Marine Ins. Co. (1885), 138

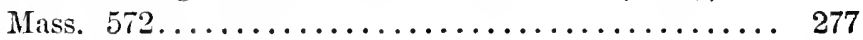

Reichard v. Manhattan Ins. Co., 31 Mo. 518, 521.... 276 Renshaw v. Queen Anne Mansions Co., L. R. (1897) 1 Q.

B. D. $662 \ldots \ldots \ldots \ldots \ldots \ldots \ldots \ldots \ldots \ldots$. 214,228

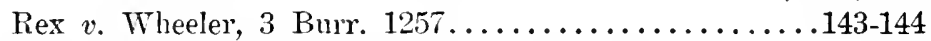

Rice $v$. Bixler, 1 W. \& S. $456 \ldots \ldots \ldots \ldots \ldots \ldots \ldots \ldots . \ldots 14$

Riddlesbarger $v$. Hartford Ins. Co., 7 Wall. 386 (Collect-

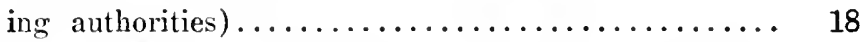

Riggs v. C. M. Ins. Co., 125 N. Y. 7 (25 N. E. 1058, 101

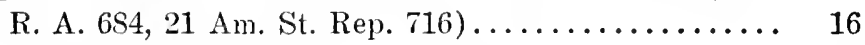

Ripley $v$. Etna Ins. Co., 30 N. Y. 136, 163......... 17 Ripley $v$. Great Northern Railway Co., 31 L. T. R. 869. .201, 227 Roach $v$. N. Y. \& Erie Co., 30 N. Y. $546 \ldots \ldots \ldots \ldots \ldots \ldots . \ldots$

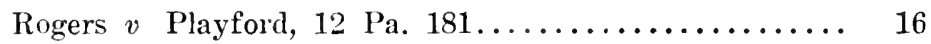
Roper $v$. Lendon, 1 El. \& El. $825 \ldots \ldots \ldots \ldots \ldots \ldots . .239,277$ Rosen $v$. United States, Pakas $v$. United States (U. S. Su-

preme Court Adrance Opinions, Feb. 1, 1918, No. 5).. 45 Rouse \& Meier, in re, L. R. 6 C. P. 212 ...191, 192, 197, 202, 227 Rowley $v$. Young, 3 Day $118 \ldots \ldots \ldots \ldots \ldots \ldots \ldots \ldots . \ldots \ldots$ Rudston \& Yates (Mich. 17 Car. in the King's Bench.).... 55 Rumsey $v$. N. Y. \& N. E. R. R. C'o., 133 N. Y. 79 (1892). . 47 Russell $v$. Pellegrini, Ellis \& Blackburn $1020 \ldots \ldots \ldots .181,182$, 
Russell v. Russell, L. R. 14 Ch. D. 471, 28 W. R. Dig. 154. . 215 Sainter $v$. Ferguson, 7 M., G. \& S. $716 \ldots \ldots \ldots \ldots \ldots \ldots \ldots 150$ Sanford v. Accident Assoc., 147 N. Y. 326.......... 240 Sanford v. Commercial Traveler's Assoc., 86 Hun $380 ; 147$

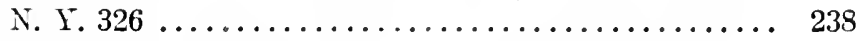

Scott $v$. Avery $(1855-56), 5$ H. L. Cas. $811 ; 25$ L. J. (Exch.) 308; 8 Exch. Rep. 487.....69, 170, 171, 175, 176, $178,180,182,185,186,187,188,189,190$, 193, 194, 195, 201, 203, 204, 205, 206, 207, $208,210,212,214,217,218,219,226,227$, $228,229,230,239,243,250,252,253-254$, $264,265,266,267$

Scott $v$. Mercantile Accident \& Guarantee Ins. Co., 66 L. T.

R. $811 \ldots \ldots \ldots \ldots \ldots \ldots \ldots \ldots 195,199,213,219,228,239$ Scott v. San Sandeau, I. Q. B. 109a, I Adolphus \& Ellis

Reports (N. S.) 456, 3 Bl. Com., p. 17, note $14 \ldots \ldots 37$ Seligman $v$. Le Boutillier, L. R. 1 C. P. $681 \ldots \ldots \ldots \ldots . \ldots 183,227$ Shiell $v$. M'Nitt, 9 Paige 101................ 149

Slater $v$. May, 2 Ld. Raymond $1072 \ldots \ldots \ldots \ldots \ldots \ldots \ldots \ldots \ldots \ldots \ldots \ldots \ldots \ldots \ldots \ldots$ Smith $v$. Compton, 20 Barb. 262............. 236 Smith \& Service (1890), L. R. 25 Q. B. D. 545....196, 222, 227 Snodgrass $v$. Gavit, 28 Pa. 221 (1857)............. 15 Southcote, in re case of, 4 Rep. 83 b............ 137 Spackman $v$. Plumstead Board of Works, L. R. $10 \mathrm{App}$.

Cas. 229 ......................203, 227

Springer $v$. United States, 102 U. S. $586 \ldots \ldots \ldots \ldots \ldots 42$ Spurrier et al. v. La Cloche, 71 L. J. (P. C.) 101; L. R. [1902] A. C. $446 ; 86$ L. T. H. $631 ; 51$ W. R. $1 ; 18$ T.

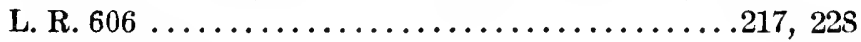

Stapilton $v$. Stapilton, 1 Atk. 3............... 14 State $v$. Bohan, 15 Kansas $407 \ldots \ldots \ldots \ldots \ldots \ldots \ldots \ldots . \ldots$ The Steam-Boat Thomas Jefferson, 10 Wheaton 428 (1825) 43 Stewart $v$. Brooklyn and Crosstown Railroad Co., 90 N. Y.

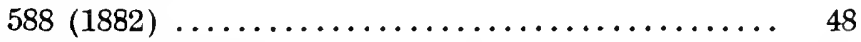

Stoddard $v$. Mix, 14 Conn. 12................ 14 Stone v. Marsh, 6 Barnewall and Cresswell $551 \ldots \ldots \ldots .41$ Street $v$. Rigby, 6 Vesey Jr. 814.......159, 162, 163, 164, 165, $166,169,170,239,250,251$ 
Tailor, in re., Six Carpenters' Case, 8 Rep. 147a....... PAGES Taylor v. Marling, 2 Manning \& Granger's Reports 55

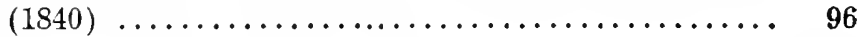

Taylor $v$. Patrick, 1 Bibb. $168 \ldots \ldots \ldots \ldots \ldots \ldots \ldots . \ldots$

Theft, in the matter of. Y. B. 13 Edw. 4, p. $9 \ldots \ldots \ldots \ldots .79$ Thomas $v$. Sorrell (1673), Freeman's Reports $85 \ldots \ldots \ldots 131$ Thompson v. Charnock, 8 T. R. 139.....166, 169, 170, 190, 222, $226,227,233,234,239,243,245,250,262$ Thomson v. Anderson, L. R. 9 Eq. 523.........190, 197, 227 Thurston $v$. Fritz, 91 Kansas, $468 \ldots \ldots \ldots \ldots \ldots \ldots \ldots .49$ Tylford $v$. French, 1 Keb. 635, 599, 15 Car. II in B. R.

(1664), 1 Levinz. 113 ...................100-102

Tobey $v$. The County of Bristol et al., 3 Story 800,821 , Fed.

Cas. no. 14065 ...................... 244, 251

Toledo S. S. Co. v. Zenith Transportation Co., 184 Fed.

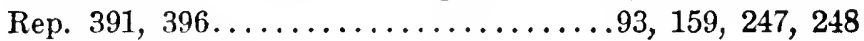

Townsend $v$. Masterson, 15 N. Y. $587 \ldots \ldots \ldots \ldots \ldots \ldots .16$

Trainor $v$. Phoenix Fire Assurance Co., 65 L. T. R. 825

$174,194,210,214,219,228,239$

Tredwen $v$. Holman, 1 Hurlstone \& Coltman $72 \ldots .186,188,192$, $193,194,219,227,228$

Trippet $v$. Eyre (1689), 2 Ventris $113 \ldots \ldots \ldots \ldots .130-131$ Trombley \& Carrier Co. v. Seligman, 133 App. Div. 525... 45

Union Insurance Co. $v$. Central Trust Co., 157 N. Y. 633. 84 Union National Bank v. Chapman, 169 N. Y. 538, 545... .16, 241 United States $v$. Reid, 12 How. 361, 13 L. ed. 1023...... 46 U. S. Asphalt Refining Co. v. Trinidad Lake Petroleum Co., 222 Fed. Rep. 1006 ..................... 242

Universal Film Manufacturing Co. v. Bell. 100 Misc. 281, 167 N. Y. Supp. $124 \ldots \ldots \ldots \ldots \ldots \ldots \ldots \ldots \ldots$

Vawdrey $v$. Simpson (1895), per Chitty, J., 65 L. J. (Ch.) 369 ; L. R. [1896] 1 Ch.; 44 W. R. 123.......... 215

Vere $v$. Cawdor, 11 East's Reports $568 \ldots \ldots \ldots \ldots \ldots \ldots .42$ Viney $v$. Bignold, L. R. 20 Q. B. D. $172 \ldots \ldots \ldots \ldots$...204, 227 Vivion $v$. Wilde. See Vynior's Case.

Vynior's Case. Y. B. at 7 Jac. 1, rot. 2629. Brownlow and Goldesborough's Reports (2nd ed. 1654), Coke's Peports, Part VIII, at p. 80.....84-102, 105, 106, 107, 113, 
$115,129,131,132,167,170,183,188,191,19 ?$, $196,205,223,226,227,234,243,247,252,266$

Walmsley $v$. White, 40 W. R. 675 (1892) ............ 215

Warbrooke v. Griffen, 2 Brownl. 254; Moore S76, 877, S. C. 66

Warburton $v$. Storr, Barnewall $v$. Cresswell's Reports, 103.. 90 Waters v. Taylor, 15 Ves. Jr. 10....158, 159, 160, 161, 165, 166, $169,170,172,174,175,197,205,206,207$, $222,227,230,239,244,250,265,274$

Watson $v$. Wetter, $91 \mathrm{~Pa} .385 \ldots \ldots \ldots \ldots \ldots \ldots \ldots . \ldots \ldots$ Wellington $v$. Mackintosh, 2 Atk. 569 (1743)....154, 156, 157, $160,169,170,227$

Whitfield $v$. Levy, 35 N. J. Law Reports $149 . . . \ldots \ldots \ldots .148$

Wickham $v$. Harding, 28 L. J. (Exch.) $215 . . . . . .182,183,227$

Wilde $v$. Vinor. See Vynior's Case.

Wilkinson $v$. First National Fire Ins. Co., 72 N. Y. 499... 17

Williams v. Fire Association of Philadelphia, 119 App.

Div. 573 ........................... 18

Wills $v$. Macearmick, 2 Wilson, $148,149 \ldots \ldots \ldots \ldots \ldots .65$

Wilson $v$. Glasgow Tramway Co. (Je. 22, 1878), 5 Sess.

Cases (4th Ser.) $981 \ldots \ldots \ldots \ldots \ldots \ldots \ldots \ldots \ldots . \ldots 262$

Winter $v$. Trimmer, $1 \mathrm{Wm}$. Black, $395 \ldots \ldots \ldots \ldots \ldots \ldots . . . .6149$

Wiseman $v$. Roper, 1 Chane. $158 \ldots \ldots \ldots \ldots \ldots \ldots . . .614$

Wood $v$. Lafayette, 46 N. Y. $484 \ldots \ldots \ldots \ldots \ldots \ldots \ldots . . . . .236$

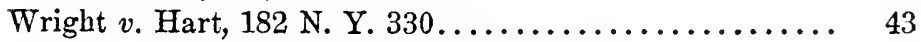

Yeomans $v$. Bell, 151 N. Y. $230 ; 45$ N. E. $552 \ldots \ldots \ldots \ldots .69$

Zane v. Zane, 6 Munf. $406 \ldots . . . \ldots \ldots . . . . . . . . . . .14$

Zenith case. See Toledo S. S. Co. 


\section{INDEX}

(References to books will be found indexed under Bibliography. References to eases and statutes will be found indexed under Tables of Cases and Statutes.)

Abbot, Everett V., 39

Action is to be upon the award, 232,265

See also Arbitrators must decide before an appeal may be made.

Action on revoked covenant, 113115,154

Agency, nature of, not clearly understood in early development of English common law, 63-69

Agreement to arbitrate no hindrance to litigation, 155 . $157,173-177,185,189,217$, $221,231,232$

See also Ousting court of jurisdiction.

Agreements, containing clause "In the usual way," explained, 271

Agreements given effect under certain qualifications, 232

'Agreements must be enforced, 165-169, 183

See also Revocability.

Allen, Judge, 13, 185, 227-237
American courts ousted by foreign courts, 272-278

American law, judicial errors in, 226-240

Appeals from agreements justifiable, 163-165

Arbitration, cause of, 18

See also Commercial arbitration.

considered unconstitutional, 240

contrary to public policy under old rule of law, 233

development of as part of the English Common Law, 106 . 107

disputes which may be arbitrated, N. Y. S., 286

expert opinions gained by, 8 , 26,156

forms of, 11, 286

history of, 24-38, 105

ancient, 25

Austria-Hungary, 31

Belgium, 37

China, 37

Denmark, 28

Edinburgh, 30

France, 27, 30, 32, 33

Germany, 37

Greece, 24, 36

Hebrew state, 29

Holland, 31

India, State of Nepal, 36 
Arbitration, history of, Ireland, 30

Italy, 30, 37

Japan, 35

Netherlands, 37

Norway, 37

Persia, 35

Portugal, 37

Rome, 27, 29

Scotland, 28, 37, 58

Spain, 30, 33, 37

Sweden, 37

informal, 286

international, 3

a means of ascertaining the eause of action to be decided by the eourts, 174 $175,184-186$

parties eligible to arbitrate in N. Y.S., 286

the present is the age of, 34 present methods irregular, 18 a preventive of litigation, 7 revocation of references, 16 the right of liberty in Franee, 34

satisfaetion afforded by, 35,38 atisfaetion of, in England, 267 a social funetion, 18, 19

under auspices of the N. Y. S. bodies, 287

under auspiees of the N. Y. S. Bar Assoeiation, 287

under the eode of N. Y. S., 287 versus Judieial disposition of commereial controversy, 8 versus Judicial procedure, 19

Arbitration agreement adopted by the Publie Service Commission for the first district of N. Y. S. with the Interborougl Rapid
Transit Co. of N. Y., form of, $298-300$

arbitrators, appointment of, fees, ete., 299-300

bearing by arbitrators, 299 . 300

litigation, times when it is legitimate, 300

manner of conducting arbitration under, 299-300

submissions, conditions of under, 298

Arbitration clause essential to a eontraet, 183

Arbitration elauses explained, 266

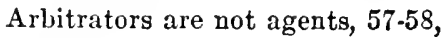
95

as agents. See Arbitrators, definition of.

authority of, countermandable, $53-59$

Boards of, Chamber of Commeree of N. Y., 6

Court of sessions, England, 8

Grecian, 36

Holland, 31

New Amsterdam, 5, 6

decisione of, final and binding, $181-183,192$

definition of, 55

Judge Andrew's, 234

jurisdiction of not to be ousted

by courts, 216

lawyers as, desirability of, 10, 11

must determine before parties resort to courts, 174-176, $182,193,203-204,207-$ $214,219,229,232-233$

official list of, 10 
Arbitrators, power of, 55

in re, to partnership, 215

Artificial reasoning of judiciary, 56-57

Ashbourne, Lord, 270

Ashton, Justice, 54, 123-124, 143

Assumpsit, development of, 63 . 65

Authority, doetrine of, application and revocability of, 129.134

Awards, early English opinions as to whether awards are of as high legal nature as an obligation, 101

enforeement of, 134.135, 183

See also Agreements must be enforced.

final and binding, 222, 234

meaning of explained, 155

liberally construed, 129

Bacon, Matthew, 279

Baldasseroni, 7

Bartley, Ch. J., 50

Bentwiteh, 30

Bible advises to settle disputes peacefully, 280

Bills of lading submitted to arbitration, 220-221

Bonds, Coke v. Abbott's opinion as to the form of, 9091

under seal, enforeement of was a fixed concept of the common law at an early period, 87.90

Bowen, Lord Justice, 40, 216

Bridgman, Lord Chaneellor, 132

Business men, attitude toward the law, 1, 2
Business men, wish only to establish cause of action by arbitration, 265-266

wish to keep out of courts a legitimate desire, 279

Camphell, Lord, 176-178, 181, 182, 186, 205, 253, 259, 264

Cardozo, Judge, 43, 277, 278

Carta Mereatoria, 3

Chamber of Commerce, N. Y. S., accomplishing a public good by prevention of litigation, 260-261

See also Submissions. arbitration, committee on, 9 arbitrator of, 6 coopperation with the Bar of N. Y. S., 280

satisfaction afforded business men, 9

Chancellors, early English, salary and fees of, $255-259$

Charters. See Individual names of charters.

Chicago. See Trade organizations; Municipal Court of Chicago

Clarke, Samuel B., 49

Coke, 3, 85, 91, 99, 131, 132, 136 $140,141-145$

Coke's dictum, difficult to destroy, 184

Coleridge, Lord, 37, 173-175, 194, $195,197,210,212$

Commerce of middle ages carried on at fairs, 76

Commercial arbitration, effect of war upon English practice of, 22 
Commercial arbitration, English practice of, cause, 19-20

growth of 19,22 result of, 21.23

Commercial contracts with the clanse "in the usual manner," are treated accord. ing to "the habitual form of arbitration adopted in fact," 223.225

Common law, arrested development of, $62.65,146.147$, 223,224

See also Arbitration, develop. ment of.

many principles peculiar to, are obsolete, 70

of England on arbitration changed by courts, not parliament, $245-246$

Common law courts arresting the development of common law cause turning point in history of English law, 6263

determined to drive mercantile courts out of business, 81,82

opposition to court of Admiralty, $82-83$

"Condition precedent." See Arbitrators must make awards before an appeal may be made.

Confucius believed in peaceful settlements of disputes, 280

Consideration, doctrine of, forced on merchants by courts of common law, 80

Contracts, arbitration clause in. troduced into, 23
Contracts, aversion of courts to sanction, 13,15

courts to be selected by parties to, in erent of controversy, 17

development of in the common law, 65

engincer or architect to be final jurige, 23

English, 22

executory, not under seal, are enforceable, 64

frecdom to make, 17

history of the derelopment under English law, 60-70

laws governing, may be stipulated by parties to, 16

Court procedure, administration of ought to be within the understanding of laymen, 2

See also Arbitrators, boards of ; Litigation; Municipal court.

Courts, arbitration encouraged by, to prevent litigation, 234, 262

attitude toward arbitration, 18 , $144.145,159.163,168.169$, 198-202, 250-252, 262

See also New York Courts attitude.

power to decree specific performance of an agreement, 196

privileged to aid arbitrators by removing difficultics, 222

revocation considered a just cause for action, 153

Cranworth, Lord Chancellor, 175, $180,182,184,190,205$, 211, 220 
Cressirell, Justice, 171-172

Cullen, Judge, 238

Custom of Arignon, 3

Damages, fixing of, as a penalty, 148.149

Davis, Judge Vernon M., 260

Debt, want of consideration originated with, 66

Defendant upon an award should be notified of award by arbitrator, 115

Denman, C. J., 37

Difficulties of safeguarding clients against ineffective agreements in case of breach, 150-152

Discoreries, courts relieve upon a bill for, 154.155

Dodridge, J., 143

Earl, Judge Robert, 17, 48

Eldon, Lord, 159-165, 167-169, $171,207,265,266,274$

Ellenborough, Lord, 42, 67, 126, 275,278

English Arbitration Committee, growth and success of, 20 . 23

English common law reports, effect of, upon arbitration, 231

English courts ousted of jurisdic. tion by courts of Hungary or Germany, 218, 267

English law, confused state of, 207

Equity, cost of, versus cost of arbitration, 29

Errors cause other errors, 238 . 239,246

See also Judicial errors.
Esher, Lord, 194, 195, 196, 197, 214

Fancher, Enoch L., 6

Fees, loss of, real cause of early English opposition to arbitration, 253.25.5

Fines and penalties, passing of, 148-152

Gild merchant, 4

Gild of St. John of Beverly, 4

Gilds, eity of London, 5

eity of York, 4

Grier, J., 15

Hamburg court, 220

Hardwicke, Lord, 154, 157, 160

Harley, Herbert, 18

Herschell, Lord Chancellor, 209, 270

Hollister, Judge, 247-248

Holmes, Justice, 41, 276

Holt, Lord, 138-139

Horwood, 118

Hough, Judge, 16, 52, 242-249

Illinois law of arbitration, 294. 298

arbitrators, compensation of, 297

number of, etc., 295

power of, 295-296

awards, nature and enforcement of, 296

definition of terms, 298

hearings of controversies, rules for, ete., 295

jurisdiction of the court under, 296-297

parties eligible to arbitrate under, 294 
Illinois law of arbitration, repeal of the act of 1873,298 revocability of, 295,297 subjects that may be arbitrated under, 294

witnesses, fees, etc., 295 writs of error and appeals from decision of court, 297

Implied quantum meruit. See Promise implied.

Intention of parties to an agreement decides system of law which shall govern their contract, 267-273

See also System of the law. governs decision as to validity of arbitration, 241

governs decisions upon contracts, 232, 267-273

Jeffreys, Lord Chancellor and Baron, 135, 137, 213, 274 Jessel, Sir George, 138, 201, 202

Judges' motive in preventing arbitration from ousting jurisdiction of the court, 231

Judicial error, 184, 213, 221

judicial method is wisest way to correct, 40

leaves its impress, 184

Jurisdiction of courts, re arbitra. tion, 208-209

defined, 273-274, 278

Justice, administration of, prelimiun $\mathbf{v}$ report on eff. eiency in, 290

arbitration is satisfactory process of administering, 31-32 See also sperdy justice.
Kenyon, Lord, 162, 164-166, 169, 171,233

Kinnear, Lord, 271

Knowlton, C. J., 272, 278

Lauer, Judge, 6

Law, uncertainty in, 39

Law merchant a branch of the Law of Nations, 72.73, 79 development of, 73

outgrowth of the market law founded by merchants, 75 Law of admiralty, development of, 76

Law of nations identified with law of nature, 79

Limitations, statutes of, made by contractors, 17

Limitations of subjects of which courts have jurisdiction, 273

Limitations of time within which suits may be brought adjusted by coutract, 273

Litigation, fear of, the cause of arbitration, 18

See also Prevention of unnecessary litigation.

modern courts do not encour. age, 260

prevention of, favored by "Public Policy,"' 14

London Court of Arbitration, protest of, to N. Y. Chamher of Commeree upon Judge Hough's decision, 242

Loughbnrougn, Lord Chancellor, 154

Lurton, Justice, 42

Macdonell, Sir John, 22

Macklin, Charles, 39 
Mansfield, Lord, 71.75, 129, 137, 143,154

Market courts, origin and development of, $76 \cdot 78$

Martin, Baron, 16, 186, 190, 194

Massachusetts courts, attitude toward arbitration, 276

Maule, J., 16, 57

Montague, Sir Henry, 102, 142, $143,154,155,213$

Moulton, Fletcher, 151

Municipal Court of Chicago, rules governing arbitra. tions, 301-302

jurisdiction, 301

law of 1917, 301-302

submission to arbitration, forms of, 302-303

Municipal Court of New York, arbitration and conciliation branch of, 6,7 arbitration, rules for, now in operation in, 306-309

arbitrators, duties of, 307 awards, 307

establishment of, 306

fees, 307

forms of arbitration, 307.309 parties eligible to submit, 306 record of proceedings, 307 zevocability of the submission, 307

submissions, conditions to, 306 Mutual promises. See Promise implied.

New York City. See Arbitrators, boards of ; Municipal Court of.

New York courts, attitude toward arbitration, 12, 230235
New York State. See Chamber of Commerce, N. Y. S.

" Ousting courts of jurisdiction," 206-207, 210,244, 250

Sce also Agreement to arbitrate no hindrance to litigation; Appeals from agreements.

American explanation of, 231 233

not possible through arbitration, 172, 175, 176, 194, 211, 262-264

origin of the phrase, 153, 243

Ouzel Galley Arbitration Society, 30

Page, Judge, 45

Park, J., 127

Parker, Judge, 17

Parol contracts, development of law of, 68

Parol submissions insecure method of arbitration under the early English law, 98.100, 107.109

Pendency of arbitration bar to action, 113, 153

Piepoudre Court. See Market courts.

Pike, 118

Pole, 143

Prevention of unnecessary litigation, rules for, Rep't of the Joint Committee of the Chamber of Commerce of N. Y. S. and of the N. Y. S. Bar Association on, 10-11. 280, 283.238

See also Courts encourage arbitration; Unnecessary litigation. 
Prevention of unnecessary litigation, after the facts have become fixed, 284-287

after suit, 287-288

approved by Bench and Bar

alike, $260-262$

at the source, 284

committee on, 10

differences, minimizing and adjusting of, 285

favored by eourt, 11.18 purpose and scope of, 283

Promise implied, validity of, 6667, 109, 142-144, 205

Public policy, doctrine of, 244 favors arbitration, 24, 25, 177, 213

favors liberty of parties to work out their own salva. tion, 14-15, 205

foundation for decisions, 41-50 foundation of the law, 41 opposed to arbitration, 240 opposed to penalties fixed in an agreement, 149 requirements of, 17

Ransom, Judge, 1

Reason, the necessary basis for decisions, 50

Reports, inaccuracy of, 85-86, $114,118-127$

See also English common law reports.

Revocability, doctrine of.

See also Arbitrators, authority and decisions of.

development of, in American courts, 196, 227.241, 243, 247.249

hindrance to arbitration, 51, 281
Revocability, doctrine of, list of English cases on, 228

under the English law of ar. bitration, $58-59$

upheld by stare decisis, 52

Revocability of agreements, 92 . $98,103-116,157-158,167$, 184, 190-197, 201-202, 206, 222

See also Action upon revoked covenant;

Agreements must be enforced.

prohibited by statute, 267 to submit without further hin. drance to the contract, 236

upon charge of fraud, 218

of an arbitrator, power not coupled with an interest, 180

Revocation of an arbitration must be sanctioned by the eourt, 180

Romer, Lord, 274, 278

Root, Elihu, 2

Rosenbaum, Samuel G., 8, 19-22, 245,253

Scotland, law on arbitration, 58, $75,208-210$

Scott, Sir John. See Eldon, Lord.

Seldon, Judge, 240

Serrell, Judge, 44

Sharshnll, J., 68

Southmayd, Charles F., 51, 232

Specific performance. See Judicial error; Courts, power of.

Speedy justice desired by mereantile men, $2.4,7,78$ 
Stare decisis, attitude of Bar toward, 39.51 exceptions to the rule of, 47

Story, Judge, 250-252

Submissions by deed, recognition of the ralidity of, 61-67, 107-113

See also Arbitration.

by obligation as compared to submission without obligation, 94

Chamber of Commerce N. Y. S., Rules and regulations governing, 288-294

forms of, 291.294

parol or by deed may be revoked, 157

upon agreed statement of facts, rules for litigation of, 285-286

Sugden, Lord Chancellor, 157, $169,171,205,233$

Taney, Chief Justice, 43

Tenterden, Lord, 40

Thurlow, Chancellor, 95

Tracy, Judge Benjamin F., 48

Trade organizations in Chicago Rgreeing to promoto trade arbitration, list of, 303 . 306

Turley, Judge, 57

United States Shipplng Board charter, arbitration provision of, bare boat form, 301

Unnecessary litigation defined, 284

Validity of corenants under early English law, 67

Veeder, 121, 137.140

Vinogradoff, Prof., 86

Vynior's case, authority on "Authority," 128-129

authority for revocability, 54

basis of many judgments in England and United States, 84

influence of the dictum of, 157, 191, 206, 220

Watson, Lord, 208-209, 263, 269

Werner, Peroy, 10

Yolverton, 116-117, 
、 



\section{University of California}

SOUTHERN REGIONAL LIBRARY FACILITY

305 De Neve Drive - Parking Lot 17 - Box 951388

LOS ANGELES, CALIFORNIA 90095-1388

Return this material to the library from which it was borrowed.

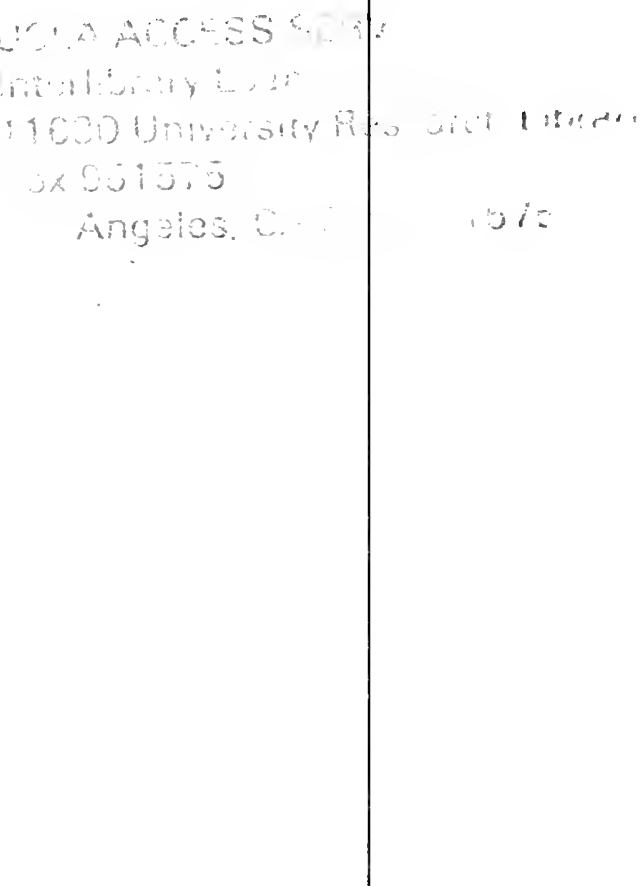


UC SOUTHERN REGIONAL LIBRARY FACILITY

AA 001006388 . 


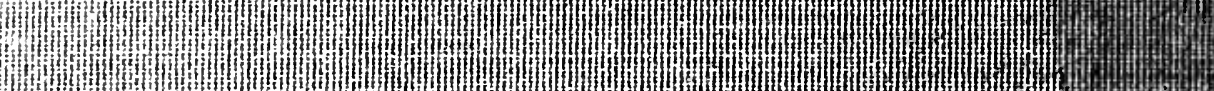

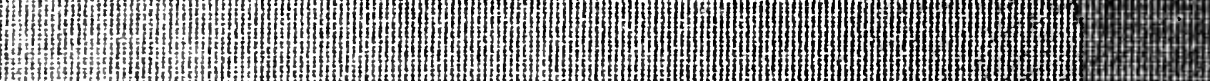
mam mWm

Wm)

mWm

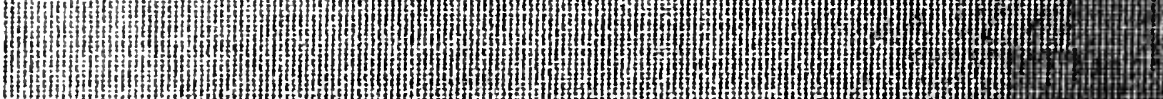
WmW

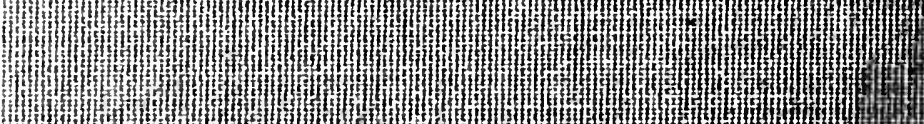

 mum

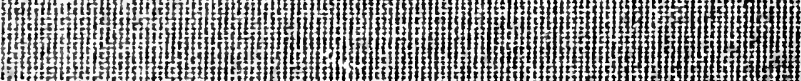

mam

W)

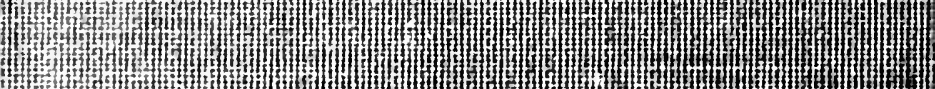

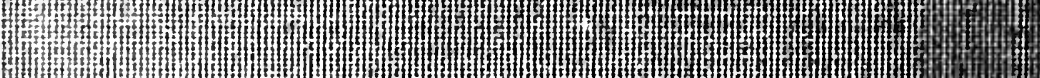

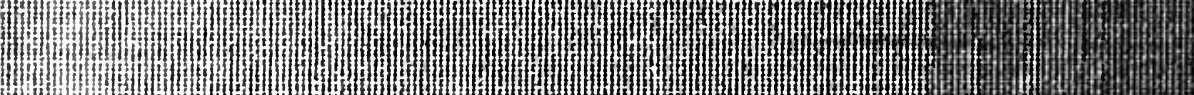

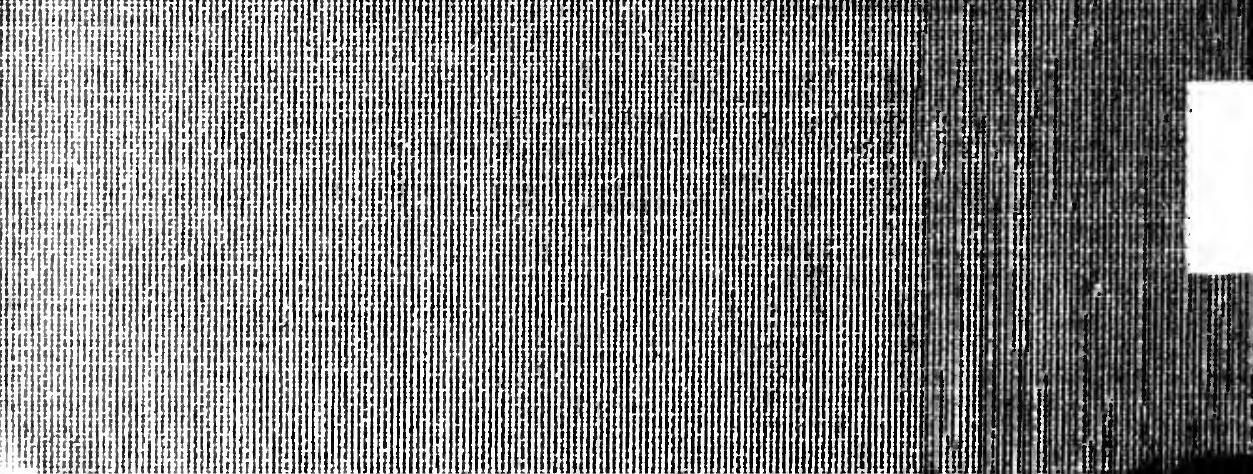

